Historic, archived document

Do not assume content reflects current scientific knowledge, policies, or practices. 



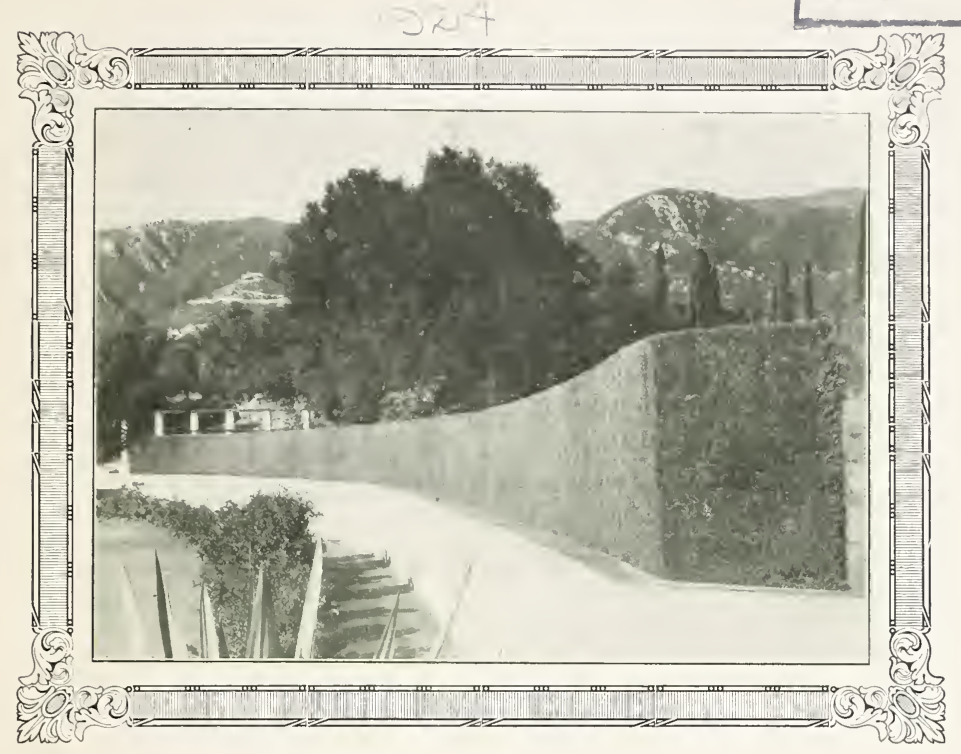

\section{THE BLUE BOOK OF GARDENING}

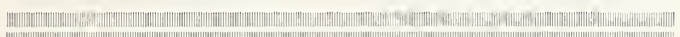

WINSEL-GIBBS SEED CO SEEDS - PLANTS - FRUIT TREES - ORNAMENTALS 211 SOUTH MAIN STREET, LOS ANGELES

Twenty-eight years of Faithful Endeavor in Producing Seeds that Grow Trees that Bear and Plants that Beautify the Earth 


\section{PARCEL POST}

\section{Seeds by Mail}

We send by mail or by express, prepaid, all orders for flower seeds, and for vegetable seeds (except beans, corn and peas). We do not pay postage or express charges on onion sets, field seeds, clovers, grasses, bird seeds, beans, corn, peas, tools or plants in large quantities; but we do pay them on other vegetable and flower seeds. Correspondents in foreign countries should add a sufficient amount for postage at the rate of 12 cents per pound.

Parcel Post rates on seeds are as follows: Owing to the convenience of having mail brought to your door by the rural delivery system, it is well to take advantage of the low rates:

Twenty pounds anywhere within the city limits of Los Angeles for $15 \mathrm{c}$.

Twenty pounds, one hundred and fifty miles, 24c, and $1 \mathrm{c}$ for each additional pound up to fifty pounds.

Nothing heavier than twenty pounds may be mailed farther than 150 miles in one package.

The Eighth Zone includes Mexico and Canada.

\section{Zone Rates}

When it is required that postage be added to the purchase price of any commodity, note the distance you are from Los Angeles, see in which Zone you live. It is then easy to estimate the exact amount of postage-required, or ask your postmaster.

\section{Domestic Parcel Post Rates}

On Seeds, Plants, Bulbs, Roots, Books, Tools, etc., within the U. S. and Possessions

First Zone

Second Zone

Third Zone

Fourth Zone

Fifth Zone

Sixth Zone

Seventh Zone

$$
\begin{aligned}
& \text { within } 50 \text { miles of Los Angele } \\
& 50 \text { to } 150 \text { ". "4 "s Ange } \\
& 150 \text { to } 300 \text { ". " " " } \\
& 300 \text { to } 600 \\
& \begin{array}{r}
600 \text { to } 1000 \\
1000 \text { to } 1400
\end{array} \\
& 1400 \text { to } 1800 \\
& \text { "4 "4 "4 } \\
& \text { "4 }
\end{aligned}
$$

For Parcels Weighing 8 Ounces or Less, containing seeds, bulbs or books only, the rate of postage to all zones is 1 cent for two ounces or fraction. (Over 8 ounces the parcel post rates apply.) 


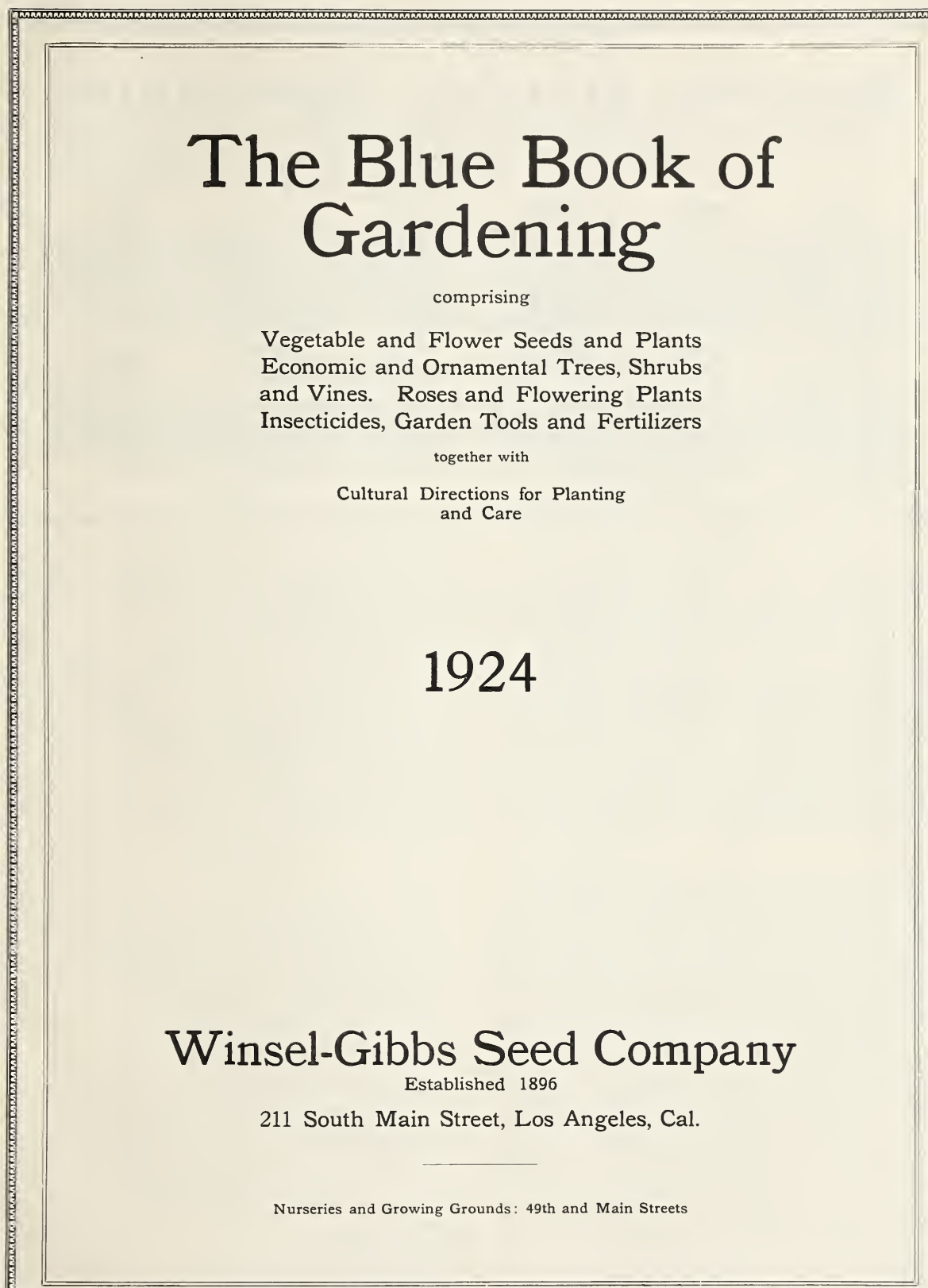




\begin{tabular}{|c|c|c|c|c|c|c|c|c|c|}
\hline a Mo Tu We Th Fr Sa & Su Mo & o Tu We T $\mathrm{T}$ & h & & Mo & & & & \\
\hline 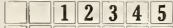 & & & & & & & & & \\
\hline $\begin{array}{llllll}7 & 8 & 9 & 10 & 11 & 12\end{array}$ & 34 & 567 & 789 & & 3 & & & & \\
\hline $\begin{array}{lllll}14 & 15 & 16 & 17\end{array}$ & 1011 & $112 \quad 13 \quad 14$ & 4151 & & 101 & & & & \\
\hline 21222324 & 1718 & 8192021 & 1 & & 6 & & & & \\
\hline $\begin{array}{llll}28 & 29 & 30 & 31\end{array}$ & 2524 & 42627 & & & & & & & \\
\hline JULYY & & AUGUST & & & & PTE & MB & ER & \\
\hline Su Mo Tu We Th Fr S & Su Mo & - Tu We Th & $\mathrm{b} F \mathrm{Sr}$ & & in $\mathrm{Mo}$ & o W & & & \\
\hline \begin{tabular}{l|llll}
1 & 2 & 3 & 4 & 5
\end{tabular} & & & 12 & & & & & & \\
\hline \begin{tabular}{l|l|l|l|l|l}
6 & 7 & 8 & 10 & 11 & 12
\end{tabular} & & $\begin{array}{ll}67 \\
\end{array}$ & & & & & & & \\
\hline 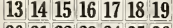 & 10 & 1121314 & 415 & & & & & & \\
\hline 202122232 & 17 & 3192021 & 12 & & 1222 & 324 & & & \\
\hline 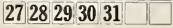 & 24312 & 262728 & & & 8293 & & & & \\
\hline
\end{tabular}

Fruit and Shade Trees. January is the best month for planting fruit trees, especially Peaches, Plums, Apricots, Almonds, Apples, Pears, Figs, Persimmons, Walnuts, etc. Most of these trees begin to grow out in February and better results are attained if transplanted when perfectly dormant.

The same applies to berry plants, such as Dewberries, Gooseberries, Blackberries, Loganberries, Strawberries and Raspberries, as well as Grapevines and Currants. Also set out this month Rhubarb, Asparagus and Horseradish roots.

Also plant deciduous ornamentals, such as Umbrella trees, Maples, Elms, Locusts, Sycamores, Planes, Willows, and deciduous shrubs.

January is the best time to prune deciduous trees and shrubs, giving the earth around them a thorough plowing or spading.

Lawns. In the vicinity of Los Angeles and, in fact, all over Southern California, all lawns are more or less infested with Devil Grass or Wire Grass. This gives a white color to the lawns, and January is the best time of the year to get ahead of these undesirable weeds, while they are not making any growth. After experimenting considerably in this way with lawns, we find that the following is the cheapest and easiest way: First mow the lawn just as close as the lawn mower will cut it, and then get enough sandy loam mixed with fertilizer to give the lawn a coat about half an inch thick all over, then sow the seed of White Clover and rake in well. White Clover will grow in cold as well as warm weather, and if enough of this seed is used, the Clover will have possession of the ground, and make a good showing all through the summer, while it will also hold down the Devil Grass and give the old lawn a bright green appearance. This operation has to be done over every year, but the cost is small in comparison with spading up the old lawn and picking out every root of the Devil Grass, which will come back anyway, if the least particle of it is left in the ground, or if any bare spots come into the lawn, as this is the natural sod of Southern California, and it will invariably come up anywhere that water is used in abundance.

Vegetable Garden. Cabbage, Cauliflower, Beets, Carrots, Chicory, Radish, Parsnip, Salsify and Lettuce can be sown. The roots of Rhubarb, Horseradish and Asparagus can be planted. In the foothills and other sheltered places, potatoes can be set out. Tomatoes, Peppers, Cucumbers and Eggplant can be sown in hot beds for transplanting next month. These beds should be covered with sashes and cloth frames at night.

Flower Garden. To get branching Asters with large flowers, they should be sown this month. Other hardy annual and perennials can be sown to advantage this month, such as Cosmos, Coreopsis, Candytuft, Centaurea, Poppies, Scabiosa, Salpiglossis, Phlox, Mignonette, Marigold, Gaillardia, Forget-me-not, Eschscholtzia and all varieties of Poppies, Daisies and Columbine. Hollyhock, Sweet William, started from seed last year, can be set out in beds about the first of the year, as they will make a good showing for several months. Plant the bulbs of Gladiolus, Narcissus and the few remaining bulbs of Hyacinths, Tulips, Anemones and Ranunculus.

\section{February}

Fruit Trees. The time of planting deciduous trees in Southern California varies considcrably from year to year, according to the weather. Some seasons one can manage to set out these deciduous trees in January and operations are sometimes delayed till February. When this is the case it is advisable to do the planting of these trees as early as possible in February because the early varieties of peaches, plums and grape vines are beginning to come in sap about the middle of that month.

February is the month to begin to plant oranges, lemons, grapefruit, guavas and alligator pears.

Roses. As explained in another part of this book we are establishing all roses in pots and cans before delivery. We pot these roses about the first of the year and by this time they are settled enough in these pots so that they can be transplanted again without a set-back. Thousands of good roses are lost every year on account of people trying to handle them bare-rooted, and customers who have tried our way of handling them know that they not only save their rose bushes but they save almost a whole season on account of our bushes beginning to grow almost immediately and begin to bloom in from thirty to sixty days after planting.

Fruit Trees. Set out Oranges, Lemons, Grapefruit, Olives, Loquats and Guavas and also Alligator Pears. Some late varieties of Peaches and Apricots can still be set out this month. 
Vegetable Garden. The first plantings of carly potatoes can be done to advantage in Fcbruary, although they will be slow in starting as the ground at this time of the ycar is still a little cold. Thercfore, we would advisc cutting the potatoes and spreading them out in a slicd for about two wecks beforc planting. If this is donc, the potatoes start much quicker. The cuts being healed over, the potatocs are not as liable to rot, espccially if therc arc hcavy rains.

Ii the cyes of the potatoes are not well devcloped, spread the tubers on top of the ground without cutting them and cover them with straw and sprinkle them occasionally.

Rhubarb, Horscradish roots and Onion sets are planted. Sow Peas, Beets, Lcttuce, Turnips, Carrots, Radishes and Spinach.

Flower Garden. Amaryllis, Agapanthus, Cannas, Dahlias, Caladium and Tubcroses can be planted this month. Gladiolus from now on, planting every month to give a succession of flowers. Pansies, Stocks, Verbenas and Salvia can be transplanted from seed beds in boxes or in the open ground. Plant Carnations, Rose bushes and all deciduous ornamental trees and plants.

\section{March}

Vegetable Garden. Eggplant, Peppers, Squash, Cucunbers and other tender plants that have been started in a hot bed the month before may be set out in the open in March. Another sowing of the same vegetables can be made for a succession of crops. Squash, Sweet Corn and Beans are planted in the average locations around Los Angeles; in fact, all kinds of vegetables may be set out during Marcl. Keep a supply of Tobacco Dust, Sulphur and Kill Sure Soap on hand to fight the insects that always appear on Melons; Cucumbers and Squash when they have two or three leaves.

Flower Garden. The following seeds may be sown this month: Ageratum, Coxcomb, Balsam, Zinnia, Snap Dragon and other summer flowering plants. Pot bulbs of Gloxinia, Gesneria, Tuberous Begonias and fancy Caladium.

Trees. Orange, Lemon, Grapefruit, Loquats, Guavas, Palms and all other evergreen trees do better if planted now than if planted earlier. The frequent rains that we get during this month help the little trees wonderfully. They will continue to grow all through the summer with very little irrigation, if they get a good start early in the spring.

\section{April}

Flower Garden. April is the month in which to set out plants for summer flowering, and especially the following: Asters, Pentstemons, Daisies, Shasta Daisies, Pansies, Chrysanthemums, Salvia, Coleus, Tuberoses, Cannas and Elephant Ears. Sow annuals of all kinds, especially Zinnia, Balsam and Snap Dragon; these three varieties are especially showy and do well during the heat of the summer.

Vegetable Garden. Early Rose and Burbank potatoes are planted this month. Melons, Squash, Cucumbers and Sweet Corn are sown. Quite often we have frequent rains in April, and under sucl conditions it is advisable to plant the seeds of Melons, Cucumbers, and Squash very shallow, as these seeds rot early in the ground if it is cold and wet. A great deal of seed of these vegetables is ruined every year on account of its being planted too deep, and when the conditions are not right, these seeds simply rot in the ground and do not germinate.

Trees. Trees of the evergreen kind, such as Oranges, Lemons and Loquats, may be planted to very good advantage in April. The ground begins to get warmer, and these trees take root more quickly than when planted in the previous months. All deciduous trees should be set out by this time, and care taken that the soil is kept in good condition around them.
Lawns. Lawns that have not received their annual ton dressing of loan or manurc should be attended to this month. Our Pulverized Sheep Mannre is recommended. It costs less and is casicst to apply and will not bring the weeds that comc up out of the yard manure that is not wcll rottcd.

Vegetable Garden. Sow Peas, Swcet Corn, Squash, Pumpkin, Cucumbers, Olira, Bccts, Carrots, Lettuce, Radish, Turnips, Parslcy and Spinach. Plant Onion scts, Cabbage, Sweet Potatoes and Tomato plants, Asparagus, Horscradish and Rhubarb roots.

Flower Garden. Sow Primula, Calccolaria in sced beds or frames and plant up to this timc. Chrysanthemum plants that are well rooted by this timc are planted in the open. All other summer flowcring plants, such as Petunia, Balsam and Zinnia, take the placc of wintcr flowering bulbs, which arc stored away in a cool place for the next season. The planting of Carpet Beds of Coleus, Iresinc and Acheranthus still gocs on this month. Dahlia, Hollyhock, Amaryllis, Agapanthus and Canna bulbs will bloom all summer if planted now. Care should be taken to have the ground manurcd heavily with old manure. Thesc plants should get plenty of watcr, as they must be kcpt growing vigorously in order to have a profusion of flowers during the summer

\section{June}

Vegetable Garden. Sow Beans and Cabbage ior late crop, Sweet Corn, Cress, Cucumbers, Okra, Muskmelon, Pcas, Parsnips; plant Eggplant, Sweet Potatoes, Horseradish and Rhubarb roots.

Keep the soil well cultivated and hoed in order that the crops will stand the heat of the coming summer.

Flower Garden. The last plants of Chrysanthemums and Asters are set out the first of this $m$ onth in order to have the plants well established before the warm weather sets in. For summer beds and borders, plant Verion Begonias, Salvia, Verbena, Petunia, Pcntstemons, Marguerites, Geraniums and Carnations. Our roses established in pots since January are in bloom and can be transplanted with perfect safety. The roses will keep right on blooming if transplanting is done with care, and will furnish flowers in the season of the year when they are very much in demand. Centaurea-imperialis and Centaurea Margarite sown this month will come in scason when they are highly appreciated.

\section{July}

Vegetable Garden. Sow Casaba Mclons, Squash, Cabbage, Lima and Green Beans, Cauliflower and Atlantic Tomato for winter crops. Lettuce, Radishes, Onions, Beets and other small truck for the home garden can be successfully sown this month, providing the seeds are covered very lightly with old burlap or mulch-manure. This prevents the soil from forming a hard crust in the middle of the day. Quantities of seed are lost every summer by neglecting to mulch the ground after seeding. These small seedlings are very tender. When just sprouting they burn very quickly when they strike the hard burning crust that is over them. This is a matter of great importance, and with a little extra care one is able to have nice, crisp Lettuce and other regetables in the heat of summer, when they are greatly appreciated.

Flower Garden. Sow Pansies and Stocks for winter blooming. Chrysanthemums have to be watched very closely from now on. All suckers should be cut off as soon as they appear, large side branches removed and only a limited number of buds left on each plant so as to throw all the strength of the plant on the few remaining buds. Green Aphis and other insects will appear, but can be easily removed by the use of Tobacco Dust. Cut back Rose bushes and keep them pretty dry. This will give them a rest and enable them to bloom heavily next winter. Eucalyptus, Acacia and other orramcntal stock may be sown this month. 


\section{August}

Vegetable Garden. The first sowing of tomatoes for winter crops is done this month. Carolina is considered the best variety for that purpose. Angust is the month for planting the second crop of potatoes. Burbank's are good varieties.

Cabbage, Cauliflower, Celery and Onions are sown for main crop. Yorkshire Hero Green Peas are sown by market gardeners this month.

Flower Garden. Sow Pansies and Stocks in well prepared seed beds out of doors; have soil light and sandy, well puiverized and leveled before seeding. Cover the seed very lightly and lay burlap right on the ground to keep the soil from baking and to keep it always moist. As soon as the seeds are up, take the burlap off and shade the ground with a lath or cloth frame for a few days. Seeds sown in boxes in greenhouses come up all right, but often they damp off and cause a great loss of time and money. Carnations, Salvia, Chinese Pinks, Verbena, Petunia, etc., may be sown in the same way. Primula and Cineraria seeds have to be sown in a box filled with very fine screened leafmold and sand, the seeds themselves are barely covered. The box is then covered with a pane of glass. Great care must be taken to wipe off the moisture on the pane of glass, and also to get the little plants used to the open air by gradually taking off the glass. Primula and Cineraria are generally sown in a greenhouse or cold frame. The bulbs of Oxalis are planted this month.

\section{September}

Vegetable Garden. Plant Onion sets, Yorkshire Hero Peas, Canadian Wonder and Ventura Wax Beans, Cabbage, Cauliflower, and roots of Rheubarb. All these vegetable seeds sown this month will come in the end of December when vegetables are at a high price.

Flower Garden. In September, place your order for fall bulbs that they may be delivered immediately upon their arrival from Europe, which will be about the first of October. Plant at this time the bulbs of Freesias and Watsonias. For Fall and Winter blooming sow the following seeds: Pansies, Stocks, Cosmos, Coreopsis, Centaurea, Salpiglossis, Cineraria and the Christmas and Winter flowering varieties of Sweet Peas, such as the Mont Blanc, Earliest of All, Blanche Ferry Extra Early. If these are sown in September they will start flowering in December and continue flowering all Winter. Transplant the Pansies and Stocks sown in August. Pot Cineraria and Primula. Roses that are expected to give flowers in winter should be watered carefully in September and given some blood meal or other good fertilizer. Acacia, Eucalyptus, Pine and Cypress seeds are sown during this month.

\section{October}

Vegetable Garden. Seeds of Yorkshire Hero Peas may be planted now, and if the Winter is not too severe will bring very nice crops in January. Vetches and Field Peas are sown this month and turned under for green fertilizer in the Spring. Sow the seed of Lettuce, Spinach, Radishes and Onions, and if a light frame can be used for covering, Tomatoes and Peppers may be sown in beds so as to furnish plants as soon as the cold weather dispels.

Flower Garden. Plant bulbs of Hyacinths, Tulips, Narcissus, Easter Lilies, St. Joseph Lily, Ranunculus, Anemones, Tritonia, Sparaxis and Freesias. More Pansies and Stocks may be sown this month. Violets, Stock and Pansy plants are put in the places where they are expected to bloom.

\section{November}

Vegetable Garden. Sow Peas, Windsor Beans, Beets, Carrots, Cabbage, Swiss Chard, Mustard, Kale, Lettuce, Parsnip, Parsley, Onion, Leek, Radish, Spinach and Turnip. The plants of the following vegetables can now be set out: Cabbage, Cauliflower, Chard, Kale, Parsley, Celery, also Onion sets and Rhubarb roots, Chives and Asparagus roots. The hot beds for Peppers and Tomato plants should be made ready this month, especially the sweet Peppers for early market should be sown this month.

Lawns. November is a good month to make a new lawn or to patch up the old one.

Take advantage of the heat that still remains in the ground at this time, which will help you to get an even stand from the lawn seed.

Flower Garden. Set out at this time the following plants: Pansies, Stocks, Aquilegia (Columbine), Canterbury Bells, Coreopsis, Rehmannia, Carnations, English Daisies, Foxglove, Gazania, Perennial Larkspur, Hollyhocks, Marguerites both the single and double, Oriental Poppies, Pentstemons, Petunias, Snapdragons, Violets and Verbenas. Sweet Peas for Spring flowering should be sown this month as well as the following seeds: Poppies, Sweet Alyssum, Snapdragon, Daisies, Centaurea, Cosmos, Candytuft, Calendula, Dianthus, Myosotis, Gypsophila, Gaillardia, Larkspur, Linum Rubrum, Phlox, Mignonette, Salpiglossis. All the bulbs mentioned in our October Calendar can still be planted in November.

\section{December}

Vegetable Garden. Sow the seed of Beets, Carrots, Cabbage, Cauliflower, Lettuce, Parsnips, Parsley, Salsify, Turnips, Radishes, Peas, and the roots of Asparagus, Rhubarb and Strawberries are planted. Tomatoes, Peppers and Eggplants are started in hot beds for early crops.

Flower Garden. Set out all the plants mentioned in our November Calendar with the exception of the Petunias. The planting of Holland bulbs can still be done. This is the best time to set out the bulbs of the Lilium Auratum, Lilium Rubrum, Lilium Candidum, Easter Lilies, Iris of all varieties and the Pips of the Lily of the Valley.

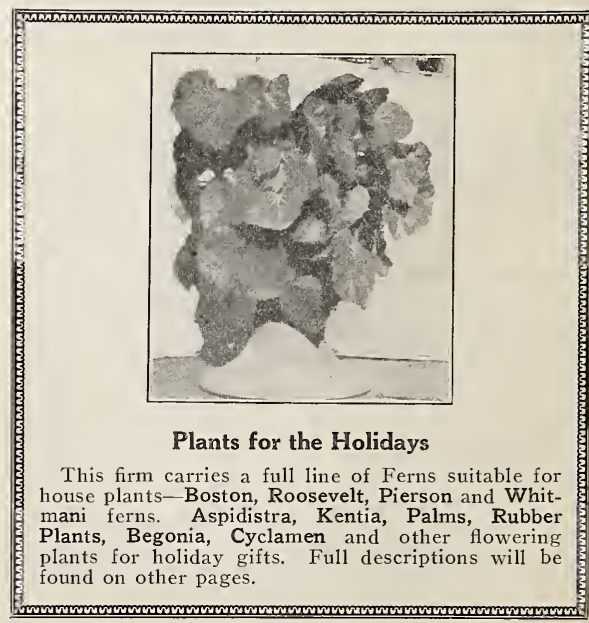




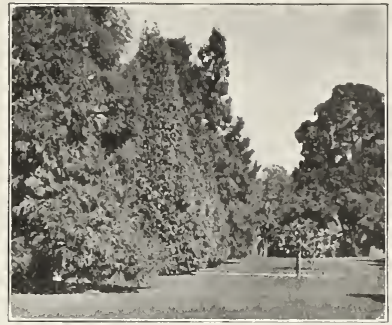

\section{Directions for Making a Fine Lawn}

The first thing is to have the soil well spaded up and pulverized. On places where the soil has been filled in, or places where no crop of any kind has been grown for a number of years, it is advisable to spade up the ground, pulverize, rake and water regularly just as if the ground had been seeded. This will start the seeds of all weeds that have been dormant for years, only awaiting enough moisture to germinate. If Salt Grass or Devil Gress shows up, pull it out, every bit of it. It will save lots of work afterward. If the soil contains much Devil Grass, it will pay to cart off the whole surface down to about two feet, and haul good loam in its place. If only ordinary weeds come up, spade them under. Repeat the operation about three weeks afterward. This will bring the soil in fine condition and save much time and money spent on pulling up weeds. Use plenty of good seed. Blue Grass, one pound for every 200 square feet; Clover, one pound to every 200 square feet. If Blue Grass and Clover are used, it is advisable to go over the ground twice; once with Blue Grass and once with Clover. This is done in order to have the Blue Grass uniformly spread all over the surface. Rake the seed in well and cover very lightly with screened or pulverized sheep manure. Great care should be taken in selecting manure for lawns. Look up our page on "Fertilizers" for directions as to selection of fertilizers.

It has been a practice around Los Angeles for teamsters to go to any corral, screen the manure, load it up and sell it for lawn purposes. This accounts for so many lawns where more weeds than grass come up, and especially for lawns where Devil Grass predominates. Almost all the Alfalfa fields in this region have Devil Grass growing in them. The grass goes to seed about the time Alfalfa is high enough to cut; it is fed to cows and mixed with Alfalfa, and is in a state of perfect preservation when picked up with manure and put on the lawns. In places where the lawn is steep, burlap is used to good advantage to cover the ground after sowing. It not only prevents the surface of the ground from drying, but it keeps the seeds from getting washed out by the frequent waterings that have to be given in such places. Watering a new lawn must be done with great care. A fine nozzle should be used to apply the water and it should always be done in the morning or evening.

\section{Care of Lawns and What Seed to Use}

It is just as essential to start a lawn right as to start a building right. A lawn must have the right foundation under it in order to last long, to stay clean of weeds and to keep its nice green color. The ground must be properly prepared and the right kind of fertilizer used, and above all, must be sown with GOOD CLEAN SEED. We have made many lawns around Los Angeles and can refer to many satisfied customers as to the results produced from having used our seeds and fertilizer. The finest lawns we have made have been those on which we used one-half pound of Kentucky Blue Grass and one-half pound of White Clover to over 200 square feet, and 100 pounds of Pulverized Sheep Manure to every 800 square feet. We can refer to the Forest Lawn Cemetery at Tropico, the Inglewood Cemetery at Inglewood, the Pacific Mutual Life Insurance Building in Los Angeles, and numerous private places, as to the results of using our material for their lawns. Hundreds of pounds of our lawn seed were used by the Rodeo Land \& Water Company at Beverly Hills for the spacious lawns of their great hotel. A visit to this place will convince you as to the quality of our lawn seed.

It is a custom of a great many public and large institutions to advertise for bids on lawn seeds without asking for samples. It is, of course, impossible for us to answer such requests for quotations, as low grade seeds will naturally be cheaper than the high grades, and we do not keep lawn seeds or any other seeds for competition purposes. IV only aim to keep the best that can be produced. We cheerfully furnish samples of our lawn seeds at any time and by comparing the quality as well as the price, purchasers will find that we are right on both.

The prices of these seeds being subject to market fluctuations, the quotations here given are for January 1 st, 1924 .

Kentucky Blue Grass... Used extensively for making lawns in Southern California. We take great pains in getting only the best seed on the market. Use one pound of seed for every 200 square feet. Price per pound, 60c. Price per sack lots on application.

Lippia Repens is a creeping plant with a very small leaf. It bears a profusion of tiny flowers which are white, slightly tinted with lavender, giving a gray effect. Sold in flats. One flat contains enough plants to cover a space 20 by 20 feet. Price $\$ 1.50$ per flat. We have a good supply of Lippia Repens at our nursery, and if in need of large quantities, will be glad to furnish prices accordingly.
White Dutch Clover. The demand for White Clover for lawns is becoming greater every day. Mixed with Blue Grass, it has a tendency to keep weeds out of the lawn; it also shelters the Blue Grass until it has made a sod and can stand the heat of the sun. Price per until it has made a sod and can stand the heat
pound, $\$ 1.00$. Price for sack lots on application.

Australian Rye Grass. Valuable for sodding dry places where Blue Grass and Clover will not thrive. Its roots being very penetrating, it gives permanency to steep inclines or rolling lawns. Is very much relished by all kinds of stock. Per pound, 30c. Price per sack lots on application. 


\section{High Grade Fertilizers}

The sclling of fcrtilizer in the State of California is done under the supervision of a regularly appointed inspector, who inspects cach lot of fertilizer as it is manufactured, and sees that it comcs up to the analysis. Our fertilizer in sack lots is sold cach with a label bearing such a guaranteed analysis, and customers buying our fertilizer are protected in this manner, and are sure to receive the value for thcir money. These fertilizers are manufactured for us and put up according to the different wants of plants and lawns, hence when ordering fertilizer, please state if it is to be used on lawns, flowers, trees or vegetables.

Do not poison your lawn and garden by using stablc manure containing straw. Straw is generally infected with the eggs of the wire worm, which hatch out and the insect gets in the plants, hollows out the stems, which causes them to slowly perish.

Never use stable manure on your lawn, and do not put this kind of manure in the soil just before setting out young plants. Astcrs, Carnations and Stocks are especially subject to this wire worm. Stable manure should only be used after being piled up for at least six months, and thoroughly worked and broken up until most of the straw has disappeared, and then it should only be used as a mulch; that is, spreading the manure on top of the ground after thorough cultivation. If trcatcd in this way, the ground will retain moisture longer, and if a lawn sprinkler is set to going on this manure, the fertilizing substances will gradually find their way to the roots.

Pulerized Sheep Manure can be used on the smallest seedling of plants or trees, on lawns, or mixed with potting soil for house plants, and is also an excellent fertilizer for the vegetable garden as well as the orchard.

In the city it is unequalled as a fertilizer and a mulch. This sheep manure sprinkled on the lawn will work its way in the sod and will remain as a covering or mulch for the roots and will remain in this way for several months, which makes it a more lasting fertilizer than the Commercial Fertilizer, and also enabling the lawn to start out quickly in the early Spring, as the lawn has in the meantime been making new roots in this sheep manure. For the above stated reasons we consider the Pulverized Sheep Manure the very best fertilizer that can be used on the lawn in the Winter or early Spring. For old lawns can be used on the lawn in the Winter or early Spring. For old lawns
that are infested with devil grass, we advise the use of a coating of this fertilizer and the sowing of one pound of Clover seed to every 500 square feet. The Sheep Manure and the Clover seed together will give the appearance of a new lawn early in the Spring.

Our Pulvrized Sheep Manure is free of weeds. It has been piled up and heated until all seeds have been started and killed by the extreme
heat, which process decomposes all animal and vegetable matter, leaving only the pure sheep manure. Every bit of it is fertilizer. It is absolutely free of hay or straw.

This manure is gathered from sheep corrals at shearing points, not from feeding stations; therefore you are buying the unadulterated concentrated sheep droppings.

The sheep are fed on ranges and all authorities agree that the manure from sheep thus fed shows a larger percentage of nitrogen and phosphoric acid than that obtained from sheep fed on hay, straw or other coarse feeds.

Price, per $1 \mathrm{~b} ., 21 / 2 \mathrm{c} ; 100-1 \mathrm{~b}$ sack, $\$ 2.25$.

Concentrated plant food enough to fertilize 25 pot plants, $25 \mathrm{c}$; large sizes to fertilize 50 plants, $50 \mathrm{c}$ each.
The approximate percentages of fertilizing elements contained in our sheep manure are as follows:

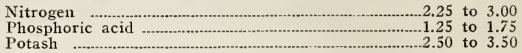

Potash .......................................................... 30 to furnish prices to those in need of large quantities.

Leaf Mould. Per sack, $\$ 1.00$. This is sold in bulk and not weight sacks.

Bone Meal is used to advantage on plants, trees and shrubbery where a slow and permanent fertilizer is required. In setting out fruit and ornamental trees, use five pounds of bone meal to each tree, which should be covered witl two inches of soil. Never place your plant directly on the bone meal. When making new roots the plant will directly on the bone meal. When making new roots the plant will gradually find its way to the bo
per $1 \mathrm{~b} ., 5 \mathrm{c}$. Per $100 \mathrm{lbs}$., $\$ 4.50$.

Blood Meal is a fine fertilizer for roses and should always be spaded in If left near the surface, it produces worms; therefore do not use in. If left near the surface, it produces worms; therefore
on house plants. Price per 1 b., 5 c. Per 100 lbs., $\$ 4.50$.

Nitrate of Soda should be used with caution. It is a powerful fertilizer and will give immediate results. One large teaspoonful dissolved is sufficient for five gallons of water. Sprinkle the loam or earth in the flower pots with this solution. In orchards nitrate of soda is used at the rate of 100 pounds to the acre. Price per 1b., 15c. Pe 100 lbs., market price furnished on application.

Mixed Potting Soil. Containing leaf moulds, sand and pulverized sheep manure, especially desirable for potting plants such as Ferns Begonias, Palms, etc. This mixture can also be used in preparing flower beds. Price per sack, $\$ 1.00$.

Commercial Fertilizer. Per 1b., 5c. Per 100 lbs., $\$ 4.00$.
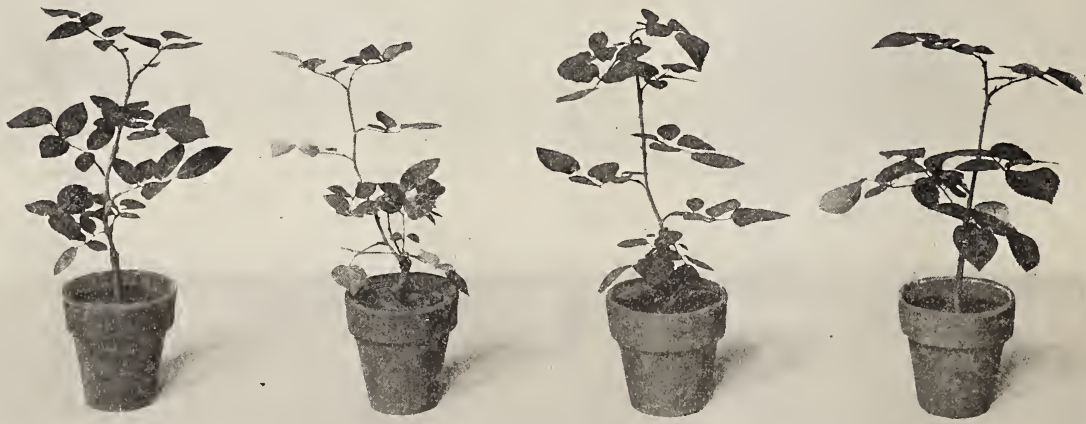


\section{Artichokes}

GREEN GLOBE. Sow in seed beds in the Spring and transplant the next season in rich soil in rows four feet apart each way. Set the roots 12 inches apart in the rows. They are the large, green globe variety; most successful in our region; deep green in color. Per package, 10c. Artichoke plants can be furnished in the Spring at the rate of $25 \mathrm{c}$ each.

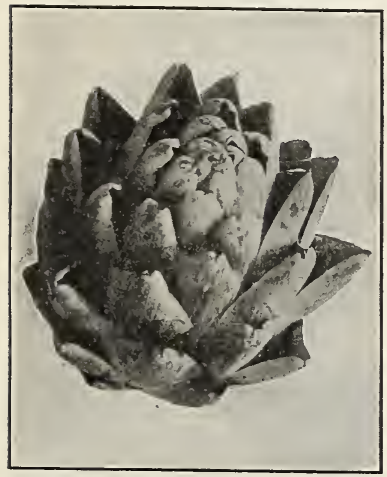

Green Globe

\section{Asparagus}

It requires two years to raise asparagus plants and one ounce of seed will produce about 800 plants. Sow in early Spring in rows 14 inches apart, thin out and allow the plants to grow two years after which time the roots should be set in rows three feet apart and the roots one foot apart.

Asparagus roots furnished in December, January and February at the rate of $25 \mathrm{c}$ per dozen for two year old plants.

BARR'S MAMMOTH. Per package, 10c ; per oz., 20c; $1 / 4$ lb., 50c, per lb., \$1.50. COLUMBIA MAMMOTH WHITE. Per package, $10 \mathrm{c}$; per oz., $20 \mathrm{c}$; per $1 / 4$ lb., $45 \mathrm{c}$; lb., $\$ 1.25$.

CONOVER'S COLOSSAL. The standard variety for home or market use. It makes large thick, white shoots of delicious flavor. Per package, $5 \mathrm{c}$; per ounce, $20 \mathrm{c}$; $1 / 4 \mathrm{lb}$., $45 \mathrm{c}$; per lb., $\$ 1.25$.

PALMETTO. One of the most popular commercial varieties. Shoots are light green, slightly tinted pink. Per package, 5c; per oz., 20c; $1 / 4$ lb., 45 c ; per lb., $\$ 1.25$.

\section{Beans}

Beans require a light, friable soil, witl plenty of moisture, and they are very, with tive to frost. In California they should be sown earlier than April 15. In the garden the soil should be made mellow and rich, and kept so, and all pole varieties should be pro vided with poles or a trellis on which to climb. For a garden crop plant String Beans in suc cession every four weeks throughout the sea. son. Sow in rows 18 to 24 inches apart, and cover from 1 to 2 inches deep, but not more. Keep the pods picked and the vines well watered and the beans will continue bearing much longer than if the vines are allowed to become dry. Hoe the rows occasionally.

For farm crop plant about 25 pounds Pole Beans per acre, in rows 36 inches apart plant Bush Beans about 35 pounds per acre in plant Bush Beans about 35 pounds per acre in
rows 24 inches apart. For the home garden there should be a succession of five or six varieties to provide the table with early, med ium and late beans.

Our smallest packages of beans sell for $10 \mathrm{c}$ but remember that you get 4 ounces of seed and not one ounce as in some packages sell ing from $5 \mathrm{c}$ to $15 \mathrm{c}$ each. These prices are postpaid in first and second zones. Write for special prices for large quantities.

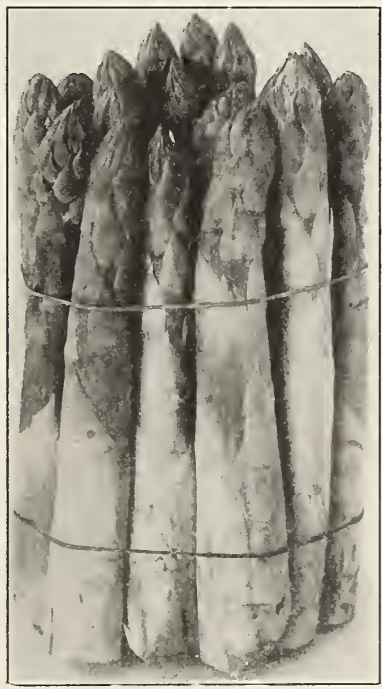

Palmetto Asparagu
Dwarf or Bush Green-Podded

BURPEE'S STRINGLESS GREEN-POD. The very best quality. We have a selection of this favorite bean which is absolutely stringless. The bods are very tender, thick, meaty and long. The plants bear well and always give satisfaction. Seed brown. Per package, 10 ; lb., 40c.

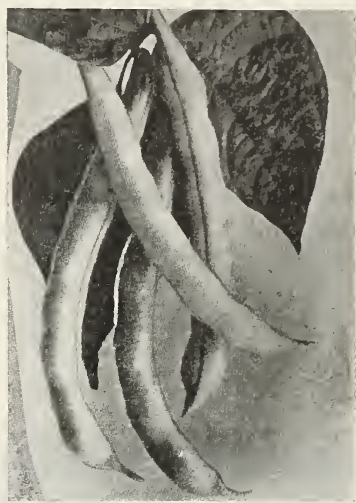

Burpee's Stringless Green Pod

CANADIAN WONDER. The leading green nodfled market bean for our section. Fine in flavor. Per package, $10 \mathrm{c}$; lb., 30c.

EARLY SIX WEEKS. One of the quickest growing and most productive beans. Pods very long and fine in flavor. Per package, $10 \mathrm{c}$; 1b., $30 \mathrm{c}$.

EARLY MOHAWK. A very hardy variety. Per package, $10 \mathrm{c}$; lb., $40 \mathrm{c}$.

EXTRA-EARLY RED VALENTINE. A popular variety. Erect vine with dark green leaves. Pods of medium length, fleshy, round and saddle-backed, with only slight strings. Seed pink, marbled with rcd. Per packagc, $10 \mathrm{c}$; lb., 40c.

EXTRA EARLY REFUGEE. A very early, green-podded variety, with medium sized, green, fleshy pods. Seed drab, freely spotted with dark purple. Their color is lighter than most of the green beans. Per package, $10 \mathrm{c} ; 1 \mathrm{~b} ., 40 \mathrm{c}$.

ENGLISH OR BROAD WINDSOR. This bean should be grown in the Fall, Winter or early Spring. It is not a string bean, but a very popular variety. It is also called the Horse Bean in some sections. Per package, $10 \mathrm{c}$; 1b., 20c. 
FRENCH KIDNEY. A hardy variety for early or late planting; will stand more cold weather than any other bean. Per package, $10 \mathrm{c}$; lb., 30c.

REFUGEE, or 1,000-to-1. There is no dwarf bean so prolific as our selection of Refugee. As many as 150 pods are sometimes found on one vine. These pods are long and green, becoming lighter in color as they mature. Not an extra early bean, but a quality is good. Per package, $10 \mathrm{c} ; 1 \mathrm{~b} ., 40 \mathrm{c}$.

\section{Dwarf or Bush Wax-Podded}

These dwarf beans have creamy white, yellow or golden yellow pods. Most of the varieties listed are stringless. The selection of wax or green-podded varieties is purely a matter of choice. The wax-podded varieties look very beautiful on the table, but as they show bruises in handling they are less frequently seen in the markets. Both classes are easily grown freight, or parcel post, see inside of front cover.

IMPROVED RUST - PROOF GOLDEN WAX. Quite rust proof, rather hardier than Golden Wax, and the pods are broader and fatter. Seed white, somewhat spotted with purplish red. This bean is a fine upright-growing variety. Per package, $10 \mathrm{c}$; $1 \mathrm{~b} ., 40 \mathrm{c}$.

CHALLENGE BLACK WAX. One of the standard wax beans. Of excellent quality and very prolific. Per package, 10c; 1b., and

GOLDEN WAX. One of the best and hand somest beans in cultivation. Pods are long, nearly straight, broad, flat and golden yellow. Seed white, more or less covered with two shades of purplish red. None will be found better in all ways than our selection of Golden Wax. Per package, 10c; 1b., 40c.

\section{Pole or Running,}

\section{Green and Wax-Podded}

These beans require a pole or trellis to climb on if planted in the garden, although when raised as a seed crop they need no support. Pole beans are very prolific and bear longer pods and a great many more than the bush variety.

BURGER'S GREEN-POD STRINGLESS POLE, OR WHITE SEEDED KENTUCKY WONDER. A new pole variety of great merit. Bears long, green, brittle, stringless pods of excellent flavor. Per stringless pods of ex.
package, $10 \mathrm{c} ; \mathrm{lb}$., $40 \mathrm{c}$.

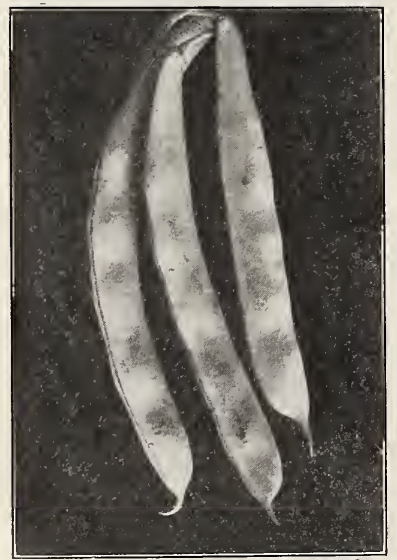

Kentucky Wonder Pole Bean

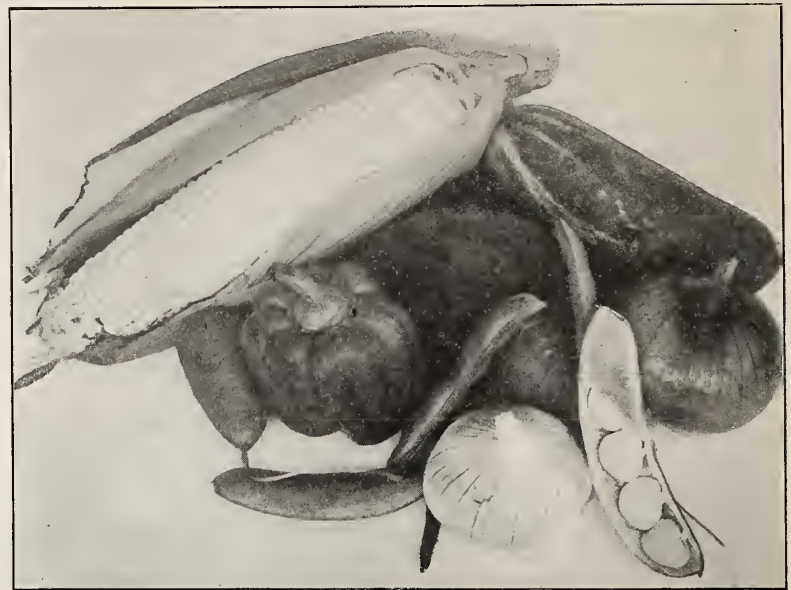

Every back yard should grow vegetables

HORTICULTURAL O R SPECKLED CRANBERRY. An old favorite. Pods short, pale green, becoming splashed with brownish red. Seed blush pink, spotted with red. Valuable either green or dry, with red.
shelled. Per ackage, $10 \mathrm{c} ; 1 \mathrm{~b} ., 40 \mathrm{c}$.

INDIAN CHIEF OR TALL BLACK WAX. A black seeded variety with thick, golden yellow pods. Very hardy and prolific, and the most opular of all pole wax beans. Pe package, $10 \mathrm{c}$; 1b., 40c.

KENTUCKY WONDER. The best and most popular of the pole varieties and should be in every garden where beans are planted. It grows luxuriantly and bears for a long grows luxuriantly and bears for a long period. Pods are very long, round and stringless, showing no signs of toughness. The seed is brown and rather long. Pe package, $10 \mathrm{c} ; 1 \mathrm{~b} ., 40 \mathrm{c}$.

KENTUCKY WONDER WAX. An excel lent variety and one of the very best yellow pole beans. The pods are long, very thick, meaty, deeply saddle-backed, entirely stringmeaty, deeply sadderific.

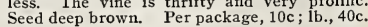

LAZY WIFE. A green-podded variety bear ing good, long pods in clusters, stringless and of peculiarly fine flavor. Seed rather large, thick and white. Per package, $10 \mathrm{c}$ lb., $40 \mathrm{c}$.

SCARLET RUNNER. The well known and old fashioned climber, having bright scarlet, pea like flowers. It not only holds its pea like flowers. but the pods, when young, place as a flower, but the pods, when young, runners bear well in San Francisco region. Per package, $15 \mathrm{c}$; lb., $40 \mathrm{c}$.

WHITE CREASEBACK. An early, green podded variety. Pods five to six inches in length, deeply creased or saddle-backed, and borne in clusters; very fleshy and stringless. Seed white and can be used as a shelled bean for winter use Can often be grown bean for winter us the variety is not such a long climber. Is often called Blue Lake Creaseback, and is a fine canning bean. Per package, $10 \mathrm{c} ; 1 \mathrm{~b} ., 40 \mathrm{c}$.

WHITE DUTCH CASE-KNIFE. A climb ing variety with long, flat, irregular pods which become creamy white as they mature. Seed broad, flat and clear white. Per pack age, $10 \mathrm{c} ; 1 \mathrm{~b} ., 40 \mathrm{c}$.

\section{Lima Beans}

Lima beans are delicious when used green or shelled, and can be grown for this purpose in any climate. Sow bush sorts in 24 inch rows and pole varieties in hills 4 feet each way. Sow late after ground is well warmed in spring. Limas will not thrive planted in over moist soil. Have the ground well prepared and well warmed, but do not water when planting.

\section{Bush Varieties}

BURPEE'S IMPROVED BUSH. The dried beans generally show a greenish white color ing and are quite thick. Per package, $10 \mathrm{c}$ lb., $40 \mathrm{c}$.

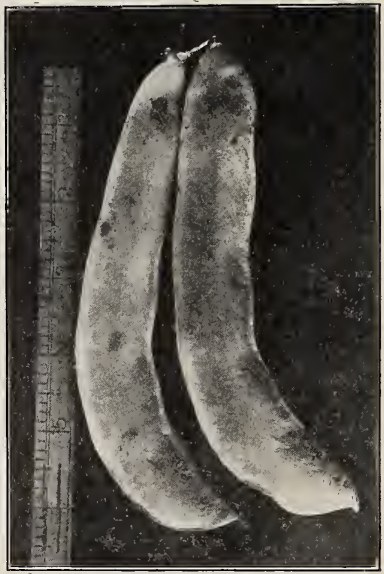

Burpee's Improved Bush Lima, Best Garden Variety 
BURPEE'S BUSH. Well known dwarf variety; pods large and the beans heavily ribbed. Per package, $10 \mathrm{c}$; 1b., $40 \mathrm{c}$.

FORDHOOK BUSH. The beans are round and thick, of mild, delicious flavor. Per package, $10 \mathrm{c} ; 1 \mathrm{~b} ., 40 \mathrm{c}$.

HENDERSON BUSH, Or BABY LIMA. Per package, $10 \mathrm{c}$; $1 \mathrm{~b} ., 40 \mathrm{c}$.

\section{Pole Varieties}

KING OF THE GARDEN. One of the best and most popular main crop varieties. It is medium early and has pods 5 to 6 inche long, which are well filled with good sized beans. Per package, $10 \mathrm{c}$; 1b., $40 \mathrm{c}$.

\section{Beets}

In Southern California table beets are plant ed every month in the year. Sow in drills about 18 inches apart, in deep sandy loam. Thin out so as to leave the plants five inches apart.

CROSBY'S EGYPTIAN. The best known and most popular variety. Very early and of fine quality. Globe shaped; bright red with clear vermilion flesh. Per package, $5 \mathrm{c}$; oz., 20c; $3 / 4$ lb., $45 \mathrm{c}$; 1b., $\$ 1.25$.

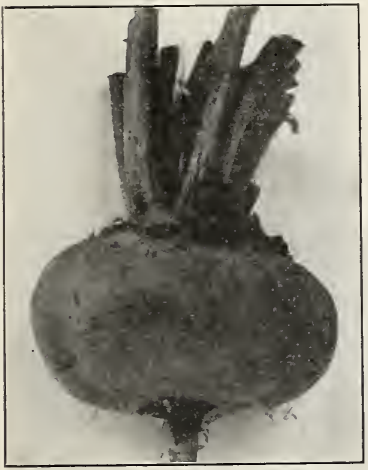

Detroit Dark Red Beet

DETROIT DARK RED. An extra fine beet, and the one we recommend for all garden purposes. Globe shaped; bright, but rich red flesh. Tops small and green. Per package, $5 c$; oz., 20 c; $1 / 4$ lb., $45 c$; lb., $\$ 1.25$.

EARLY WONDER. A new introduction, surpassing all other varieties. A refined, even strain of an early globe beet witb rich crimson scarlet flesh. Owing to rich crimson scarlet fiesh. mercial beet. Per package, 10c; oz, 30c ; mercial beet. Per pack
$1 / 4$ lb., 75c; 1b., $\$ 2.50$.

EARLY ECLIPSE. A fine, early table beet. Top shaped or tapering; flesl deep crimson, zoned with pink, crisp and sweet. Per package, 5c; oz., 20c; $1 / 4$ lb., $45 \mathrm{c}$; lb., $\$ 1.25$.

EARLY BLOOD TURNIP. A good variety for summer and autumn use. Is turnip shaped, with bright red flesh, showing zones. Per package, $5 \mathrm{c}$; oz., $20 \mathrm{c}$; $1 / 4$ lb., $45 \mathrm{c}$; lb., \$1.25.

HALF LONG BLOOD. A half long variety about 8 inches long and tapering abruptly. Very rich, deep red flesh of fine quality. Per package, 5c; oz., 20c; @1b., 45c;1b., $\$ 1.25$.
EXTRA EARLY EGYPTIAN. A flattish, turnip shaped variety with dark red flesh, showing zones of a lighter shade. Dark leaves. A good table beet and very early. Per package, 5c; oz., 20c; 1/4 lb., 45c; lb., $\$ 1.25$.

LONG SMOOTH DARK BLOOD. A very desirable variety for light soils, where roots are easily dug. Skin very dark brownish red; flesh decp blood red. Per package, $5 c$; oz., 20c; $1 / 4$ lb., $45 \mathrm{c}$; lb., $\$ 1.25$.

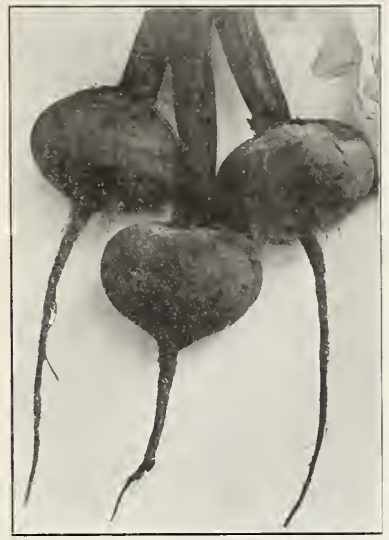

Eariy Wonder Beet

\section{Mangel Wurzel or Stock Beets}

In Southern California table beets are plant ed every month in the year. Sow in drills about 18 inches apart, in deep sandy loam. Thin out so as to leave the plants five inches apart.

CHAMPION YELLOW GLOBE. A large, round, orange yellow variety. Good for shallow soils. Per package, $10 \mathrm{c}$; 1b., 60c ; 10 lbs., $\$ 5$.

GIANT YELLOW INTERMEDIATE, OR GATE POST. A large, oval shaped beet, with white flesh, zoned with yellow. Per package, 10c; 1b., 60c; 10 lbs., $\$ 4.75$.

GOLDEN T A N A R D. Yellow fleshed. Grows partly above ground. The flesh is Grows partly above ground. very solid, yellow, zoned with white. Makes a fine feed, and cattle do not tire of it.
package, $10 \mathrm{c} ; 1 \mathrm{~b} ., 70 \mathrm{c} ; 10$ lbs., $\$ 6.50$.

MAMMOTH LONG RED. The largest of all the Mangels and the heaviest cropper. Skin is red; flesh white, zoned with red. This variety produces a larger amount of good feed than any other beet, and is recommended as superior to all others. Per package, $10 \mathrm{c}$; 1b., 70c; 10 lbs., $\$ 6.50$.

\section{Sugar Beets}

GIANT HALF SUGAR, GREEN TOP. A beet which is superior to mangels for stock feeding purposes, as it is more nutritious, having a large amount of sugar. It is oval in shape and grows partly out of the ground; size large and yields enormousty Per package, 10c; 1b., 70c; 10 lbs., \$6.

WHITE SUGAR ROSE TOP. For feeding stock, A very hardy variety, producing large crops with little care. The root is large crops with litte care. The while not surficiently so for sugar purposes, it makes sufficiently so for sugar purposes, it makes
a remarkably fine, rich food for stock. Per package, $10 \mathrm{c}$; 1b., $70 \mathrm{c}$; $10 \mathrm{lbs}$., $\$ 6.50$.

\section{Brussels Sprouts}

The plants are very hardy and grow from 2 to 3 feet high, bearing a large wass of leaves at the top. The sides of the main stem are covered with three or four dozen small cabbage heads, which are broken off and cooked the same as cabbage. The sprout mature in succession. Sow early so as to have well grown plants by fall.

IMPROVED HALF DWARF. Grows 2 to 3 feet high and is well covered with small, firm sprouts, Per package, $5 c$.

\section{Cabbage}

Good cabbages are to be had at all seasons of the year in some parts of the country; and seed can be planted almost any time of tbe year. However, there are three good seasons for sowing the seed: In September for late winter and early spring cabbages, in March for summer and fall cabbages, and in June and July for winter cabbages. The seed sprouts quickly and is likely to come up very thick in the seed-bed. It should be thinned early and each plant given plenty of space or the plants will become spindling, and then do not head well. Never let the plants get checked by drought. Transplant to the field when 4 to 5 inches high, and press the soil when 4 to 5 inches high, and press the soil
closely about the plants. They should be put 18 to 24 inches apart, in rows 24 to 36 inches apart. To prevent the heads splitting open in the field before they are ready to be harvested, the plants should be loosened a little at the root. Cabbages require considerable moisture, but too much water causes them to rot very readily.

\section{Extra Early Varieties}

EXTRA JERSEY WAKEFIELD. One of the best and most popular early varieties. Forms roundish, pointed heads of good size. Is very hardy and on account of its thick out side leaves is able to resist cold and other unfavorable conditions to a great extent Per package, $5 \mathrm{c}$; oz., $35 \mathrm{c}$; $1 / 4 \mathrm{lb}$., $\$ 1$; lb., $\$ 3.50$.

EARLY WINNIGSTADT. A decidedly point ed head of good size and fine quality, the most sharply pointed of all cabbages. One of the hardiest varieties, resists cold, wet and insect pests to a degree which makes it very desirable. We recommend it as one it very desirable. We recommend it as one from selected strains, grown for us in Denmark. Per package, 5c; oz., 40c; $1 / 4 \mathrm{lb}$, $\$ 1.35 ; 1 \mathrm{~b} ., \$ 4$.

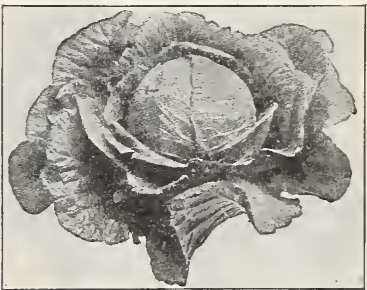

Copenhagen Market Cabbage

\section{Second Early Varieties}

COPENHAGEN MARKET. Undoubtedly the best cabbage for all conditions. Good for market growing, and home garden. Heads medium sized, firm and round. Per package, $5 \mathrm{c}$; oz., 50c; $1 / 4$ lb., $\$ 1.65$; lb., $\$ 5$.

EARLY DRUMHEAD, Round, flat heads. Excellent for the home garden or market. Per package, $5 \mathrm{c}$; oz., 40c; $1 / 4$ lb., $\$ 1.35$; lb., $\$ 4$.

EARLY DWARF FLAT DUTCH. A good flat headed variety, with short stems and hard, firm head. Per package, $5 \mathrm{c}$; oz., $40 \mathrm{c}$; I/4 lb., $\$ 1.35$; lb., $\$ 4$. 


\section{Winter Varieties}

FLOTTER'S GIANT DRUMHEAD, or World-beater for sauerkraut. Per package, $10 \mathrm{c}$; oz., 65c; $1 / 4$ lb., $\$ 2.00$; lb., $\$ 6.00$.

DANISH BALLHEAD, or THE HOLLANDER. A very late variety, forming globular heads; very hard and solid. Keep well and is a good shipper. The color is bluish green. Per package, 5c; oz., 50c ; I $/ 4$ lb., $\$ 1.65 ;$ lb., $\$ 5.00$.

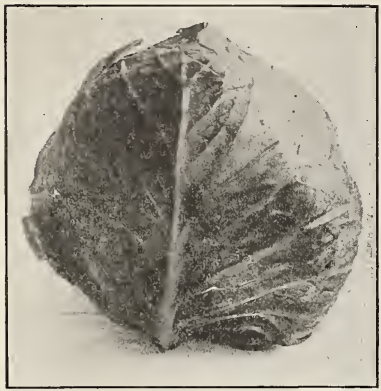

Danish Roundhead

DANISH ROUNDHEAD. A short stemmed Danish Ballhead, having all the good qualities of its progenitor and being nearly two ities of its progenitor and being nearly two weeks earlier. A main crop variety. Per
package, 5c; per oz., 50c; $1 / 4$ lb., $\$ 1.65$; package,

PREMIUM LATE FLAT DUTCH. A well known, large, late variety. Flattish round heads, very solid and firm; has rather tall, stout stem. Per package, $5 \mathrm{c}$; oz., $40 \mathrm{c}$; $1 / 4$ lb., $\$ 1.35 ; 1$ b., $\$ 4$.

\section{Savoy Cabbage}

PERFECTION DRUMHEAD SAVOY. A variety that is much prized in Europe and also by those who are familiar with it in this country. It is very sweet and crisp and always tender. Heads medium sized and fairly compact. Per package, $5 \mathrm{c} ;$ oz., $50 \mathrm{c} ; 1 / 4$ lb., $\$ 1.65 ; 1$ lb., $\$ 5$.

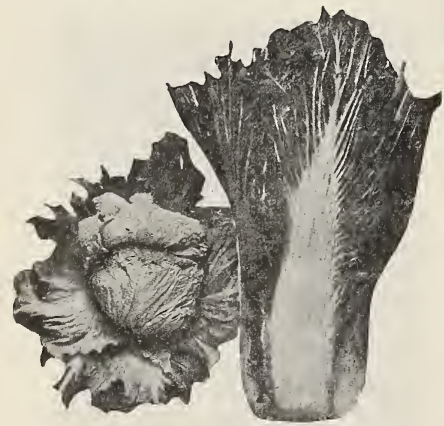

\section{Chinese Cabbage}

WONG BOK. This is the large white strain of Pe-Tsai. Has a distinct and appetising flavor. Seed imported fom China. The culture for Wong Bok is the same as for winture for Wor $10 \mathrm{c} ; 0 z, 50 \mathrm{c}$; ter cabbage. Per p.ack $\$ 1.65$; 1b., $\$ 5.00$.

\section{Red Cabbage}

MAMMOTH ROCK RED. Best hard headed ed variety, Large heads, globular; very solid and very deep red on top. Oute leaves greenish red, large, and spreading. Especially used for pickling and preferred by many. Per package, $5 \mathrm{c}$; oz., $50 \mathrm{c}$; $1 / 4 \mathrm{lb}$. $\$ 1.65 ; 1 \mathrm{~b} ., \$ 5$.

\section{Carrots}

\section{FOR TABLE AND STOCK}

Good sandy loam is best adapted for car rots of all varieties. The shorter varieties, however, can be sown on heavier lands with good results. For garden, sow the early an short varieties at any time after January and repeat often for a succession of tende roots. For general crop, sow in the open field about April 1, using four to six pounds per acre for rows 16 to 18 inches apart. While you get a good uniform root by thinning the young plants, it is not necessary to do so to young parts of California carrots can be planted every 4 weeks during the year.

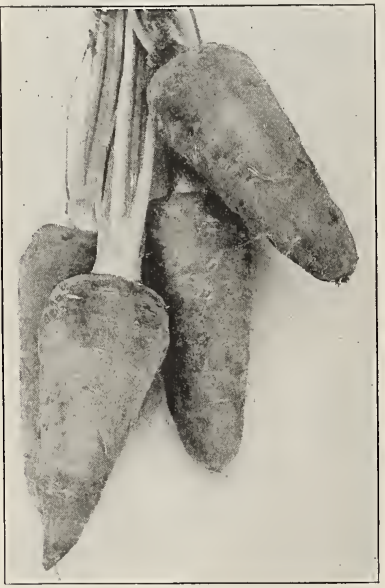

Chatenay Carrot

CHATENAY or MODEL, The roots are $5 \mathrm{I} / 2$ inches long stump rooted and a deep inches long, stump rooted, and a deep and selling on the market. Per package, $5 \mathrm{c}$; oz., $20 \mathrm{c}$; $1 / 4$ lb., $45 \mathrm{c}$; 1b., $\$ 1.25$.

DANVER'S HALF LONG. The best variety for general purposes and the most largely The perfect type is about 8 inches long and about $2 \frac{1}{2}$ inches wide at the long and about $21 / 2$ inches wide at the shoulder, tapering to a sort of half point at the bottom. Color is a bright orange scarlct. It is a very heavy cropper. Per pack
age, $5 \mathrm{c}$; oz., $20 \mathrm{c}$; $1 / 4 \mathrm{lb} ., 45 \mathrm{c}$; lb., $\$ 1.25$.

LONG ORANGE. A good heavy cropper for light soils where roots can be easily dug. The strain we offer is bright orange scar. let, fairly thick, and grows entirely underground, having no green shoulder. Brightest of the red carrots. Per pac

WHITE BELGIAN. The best known and one of the oldest white varieties with a long pointed root. The variety we offer does not grow above ground, with a green shoulder, as do some strains. Per package, $5 c ; 0 z, 20 c ; 1 / 4$ lb., $40 \mathrm{c} ; 1 \mathrm{~b} ., \$ 1$.

LONG ORANGE BELGIAN. Grown exclusively for stock; good keeper. Per package, $5 \mathrm{c}$; oz., 20c; $1 / 4$ lb., $40 \mathrm{c}$; lb., $\$ 1$.
OXHEART, or GUERANDE. One of the most popular and heaviest yielders among short carrots. The shape is particularly desirable for heavy soils. The true type is about $51 / 2$ inches long and $31 / 2$ inches thick at the shoulder. It tapers slightly to the bottom, and is very stump rooted. $\mathrm{Pe}$ package, $5 \mathrm{c}$; oz., $20 \mathrm{c}$; $1 / 4 \mathrm{lb}$., $45 \mathrm{c}$; lb., $\$ 1.25$

SCARLET HORN. A small, early stump rooted variety, of good flavor and nearly coreless. Per package, $5 \mathrm{c}$; oz., $20 \mathrm{c}$; $1 / 4 \mathrm{lb}$. $50 \mathrm{c}$; lb., $\$ 1.50$.

\section{Chicory}

LARGE ROOTED or COFFEE. Best variety for its flavor. Per package, $10 \mathrm{c}$; oz. $40 \mathrm{c} ; \mathrm{I} / 4 \mathrm{lb} ., \$ 1.35 ; 1 \mathrm{~b} ., \$ 4$.

SMALL ROOTED or RADICHETTA. A good sort for home gardening. Per pack age, $10 \mathrm{c}$; oz., 50c; $1 / 4$ lb., $\$ 1.50$; lb., $\$ 5$.

WITLOOF. Best for forcing. Per package, $10 \mathrm{c} ;$ oz., $40 \mathrm{c}$; $1 / 4$ lb., $\$ 1.35 ; 1 \mathrm{~b} ., \$ 4$.

\section{Collards}

TRUE GEORGIA. The leading variety of greens. Excellent when cooked as Spinach. Per package, 5c; oz., 20c; $1 / 4$ lb., $65 \mathrm{c}$; lb. $\$ 2$.

\section{Corn Salad or Fetticus}

LARGE LEAVED. Little known, but a fine substitute for cabbage, Per package, $5 \mathrm{c}$ oz., 30c; $1 / 4$ lb., $\$ 1$; lb., $\$ 3$.

\section{Cauliflower}

The planting of Cauliflower is easy and is much the same as that of cabbage. It does not make a good summer crop however, as it will not head up in hot weather. Cauliflower is especially popular as a fall and winter crop, and with market gardeners proves a profitable one, owing to the scarcity of good market vegetables when Cauliflower is at its best.

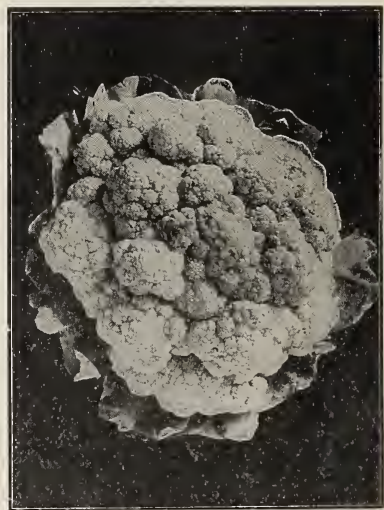

California Wonder Cauliflower

CALIFORNIA WONDER. The best winter variety. Leaves large and long, and may be tied over the head for protection. Heads be tied ovid the For fall plant. large, solida and pure white. ing. Highly recommended for $15 \mathrm{c} ; 1 / 4 \mathrm{Oz}$., $50 \mathrm{c} ;$ oz., $\$ 1.50 ; 1 / 4$ lb., $\$ 5$.

DRY WEATHER. A sure header, it will form a head when other sorts succumb to the heat. Dry Weather is of fine texture, white, a delicious Cauliflower. It is a little later than Early Snowball. Per package, $25 \mathrm{c}$; $1 / 4$ oz., $\$ 1.25$; oz., $\$ 4.50$; $1 / 4$ 1b., $\$ 14$. 
EARLY SNOWBALL. The best and most popular early variety grown. There is a vast difference in the strains of this variety offered, but what we offer is the best in. ported stock. Those wlo liave had trouble ported stock. Those wholl it will aline uniformly fine heads even un. It will make uniformly fine heads even uni. 4 oz., $\$ 1.15$; oz., $\$ 4.25$; 1/4 lb., $\$ 15$.

SNOWBALL. An early variety with short leaves and fine white lieads. About a week later than Early Sitowball and preferable in most of California. For winter planting. Per paciage, 25c; y $0 z, \$ 1.15 ; 0 \%, \$ 4.25$; I $1 \mathrm{~b} ., \$ 15 ; 1 \mathrm{~b} ., \$ 45$.

EXTRA EARLY DWARF ERFURT. VerY earl. and almost as good as the best quality of Snowball. For spring planting. Per package, $25 \mathrm{c} ; \mathrm{x} / 4 \mathrm{oz.}, \$ 1 ; 0 \mathrm{z}, \$ 3.50 ; 1 \mathrm{~b}$. $\$ 35.00$.

VEITCH'S AUTUMN GIANT. A large, late variety, very hardy, but especially desirable for the south. The large leaves protect the heads well, making this a fine variety for California, Per package, 5c; $1 / 4$ oz $50 \mathrm{c}$; Calif $\$ 1.50 ; 1 / 4$ lb. $\$ 4.50 ; 1$ l., $\$ 12$.

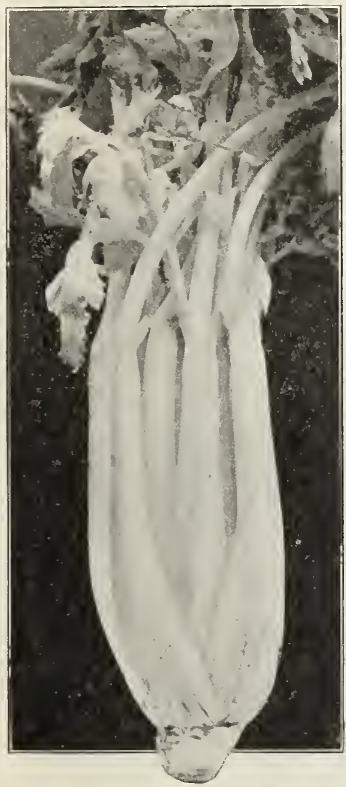

Golden Self Bleaching Celery

\section{Celery}

Plant seed in early spring in rich, mellow soil, rather sandy, in a frame or open ground. As soon as the plants are six inches high, transplant them four inches each way. Later transplant in the field in rows four feet apart in soil that is naturally rich or that has been fertilized well with rich manure. It is not advisable to plant celery in furrows in Southern California or to heap the plants up with earth, as this causes them to rust. It is far better to plant self-blanching varieties and to tie up a few plants at a time before using.
CALIFORNIA GROWN. Per package, $5 \mathrm{c}$; oz., $80 \mathrm{c} ; \mathrm{I} / 4$ Ib., $\$ 2.65 ;$ ib., $\$ 10$.

GIANT PASCAL. Ratler tall, green winter celery, blanches white and brittle. Per pack a ge, $5 \mathrm{c} ; 0 \%, 35 \mathrm{c} ; 1 / 4 \mathrm{oz}_{2}, \$ 1.10 ; 1 \mathrm{~b}, \$ 3.5 \mathrm{v}$.

GOLDEN SELF-BLANCHING, or PARIS GOLDEN. The best market variety, es pecially for early crop. The plant is naturally golden yellow (botls stem and leaves) but needs to be blanched to make it brittle and fit for table use. Forms a rather small bunch. French grown. Per package, $15 \mathrm{c}$ $\mathrm{oz.}, \$ 1.50 ; 1 / 4 \mathrm{lb} ., \$ 2.65 ; 1 \mathrm{~b} ., \$ 10$.

WHITE PLUME. A comparatively easy va riety to grow, as it is fairly hardy, and being naturally white, is easy to blanch. The leaves are also white, tinted with green at tips. Forms a medium sized bunch and is fairly tall; early. Per package, $5 \mathrm{c} ; \mathrm{oz}$ $35 \mathrm{c} ; 1 / 4$ lb., $\$ 1.20$; lb., $\$ 3.50$.

CELERY SEED FOR FLAVORING (SOUP CELERY). Per package, 5c; $1 / 21 \mathrm{~b} ., 40 \mathrm{c}$ lb., $70 \mathrm{c}$.

CELERIAC, or TURNIP ROOTED CELERY. This celery is used for soups and salads. Plant in shallow drills and give same care as celery. Per package, $5 \mathrm{c}$; oz., $30 \mathrm{c} ; 1 \mathrm{~b} ., \$ 3.00$.

CELERY PLANTS. 20c per dozen, or $\$ 1.50$ per $\$ 100$. Transplanted 100 in a box.

\section{Celeriac or Turnip-Rooted Celery}

GIANT SMOOTH PRAGUE. Fine for flavoring soups and salads. Easily grown in almost any soil. Per package, $5 \mathrm{c}$; 0z., $35 \mathrm{c}$; $1 / 4$ lb., $\$ 1.20 ; 1$ b., $\$ 3.50$.

\section{Corn}

Plant in the spring in hills; the small varieties 10 inches apart in drills $2 \frac{1}{2}$ feet apart. If sown in hills have them about three feet apart each way. Corn grows best in rich, warm soil; thorough cultivation is necessary in order to obtain good results. The following varieties are grown especially for us by Eastern specialists. Write for quotations by 100 pounds.

COUNTRY GENTLEMAN, or SHOEPEG Has a white cob, closely filled with long small "shoe-peg" kernels. Is remarkably fine flavored and sweet, and is frequently used by canners. Many people consider Country Gentleman as about the best of late corns. The stalk is tall. Plant other sorts for early, and this for late. Per package, $10 \mathrm{c}$; 1b., 30c; 10 lbs., $\$ 3.50$.

BLACK MEXICAN. Although when ripe the seed is dark bluish or black, when ready for table use it is white. It is of especially fine sweet flavor and very tender; medium early. The cobs have 10 rows of kernels. Per package, $10 \mathrm{c}$; 1b., $40 \mathrm{c}$; 10 lbs., $\$ 3.50$.

CROSBY'S EARLY. A fine, early variety, growing about 4 feet in height. Kernels smaller than a cory, having 14 rows to each ear. A rattling good sort. Per pack age, $10 \mathrm{c}$; 1b., $40 \mathrm{c} ; 10$ lbs., $\$ 3.50$.

EARLY MAMMOTH, or A L A E D A SWEET. This sort is very largely grown in Alameda County. The ears are long, in Alameda County, The ears are long, very large, and well filled with 10 to 14 good quality. Per package, $10 \mathrm{c}$; 1b., $40 \mathrm{c}$; 10 lbs., $\$ 3.50$

EARLY MINNESOTA. Between Crosby's and Cory's in earliness. Stalks about 5 feet high; ears long and 8 rowed. Per pack age, $10 \mathrm{c}$; 1b., 30c; 10 lbs., $\$ 3.50$.

EARLY WHITE COB CORY. An extraearly variety with remarkable white grains, especially when cooked. Ears are 6 to 8 inches long. Kernels are large and placed in 8 rows to each ear. Per package, $10 \mathrm{c}$. lb., $40 \mathrm{c} ; 10$ lbs, $\$ 3.50$.
GOLDEN BANTAM. A very early variety. The ears are but medium size, but are thickly set with delicions yellow kernels. The flavor of this variety is rich and nut like. Per package, 10c; 1b., 0c; 10 lbs., like. $\$ 3.50$.

OREGON EVERGREEN. Earlier than Stowell's Evergreell, and, like it, very sweet and fine. Kernels a re white; ears large. Nothing better for canning or for late corn. package, $10 \mathrm{c}$; 1b., 40c; 10 lbs., $\$ 3.50$.

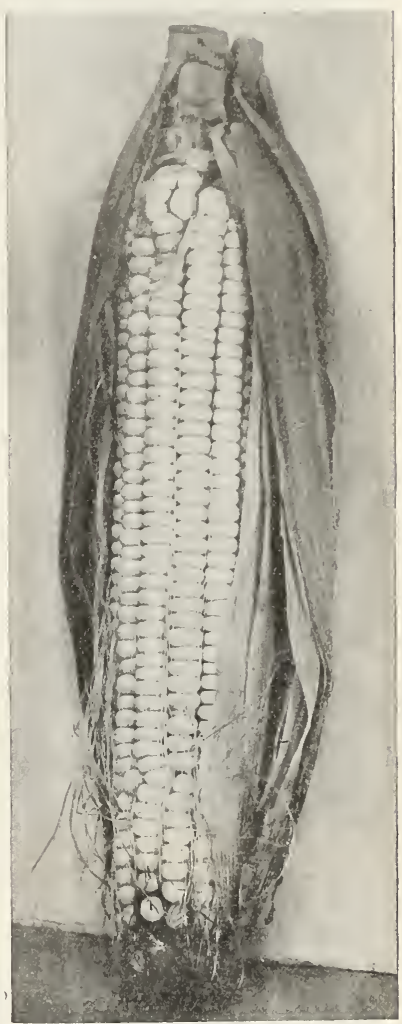

Oregon Evergreen

STOWELL'S EVERGREEN. Good all round table variety of excellent quality. Stowell's Evergreen is a late sweet corn, taking a good time to nuature; 12 rows to the ear; good time to niature; 12 rows to Stowell's Evergreen is also used as a fodder corn on account of its succulent stalks. These grow to 6 feet or more. Per package, $10 \mathrm{c}$; lb., $40 \mathrm{c}$; $10 \mathrm{lbs}$., $\$ 3.50$.

EARLY ADAMS. Although not a sweet corn, can often be used as a table corn on account of its fine, white kernels, which are quite sweet and tender. Is very hardy and can be planted earlier than the early varieties of sweet corn. Per package, 10c; lb., 20c; 10 lbs., $\$ 1.15$. 


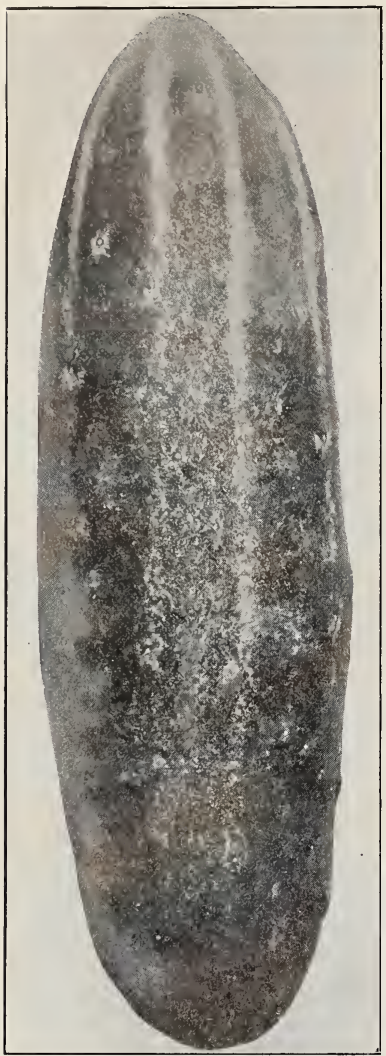

Klondyke Cucumber

\section{Cucumbers}

Cucumber seed should be sown as soon as the weather is warm enough, generally about the middle of February. The first early va. rieties are sown, of course, in sheltered locations. Around Cahuenga Valley, Eagle Rock, etc., cucumbers are sown about the middle of September for winter crops. Sow in rich, warm, sandy soil, in hills four feet apart each way, thinning to three or four of the strongest plants; hoe often and keep close watch on the insects. One ounce will plant 50 hills and two pounds will plant one acre.

ARLINGTON WHITE SPINE. Moderately dark green in color; very straight and even in shape. It is 7 to 8 inches long, early, and can be forced. Per package, 5c; oz., $20 \mathrm{c}$; $1 / 4 \mathrm{lb}$., 50c; lb., $\$ 1.50$.

CHICAGo PICKLING. Per package, 5c; oz., $20 \mathrm{c}$; $1 / 4 \mathrm{lb}$., $50 \mathrm{c}$; lb., $\$ 1.50$.

EVERGREEN WHITE SPINE. A popular variety, having long, rich, dark green fruits with very tender, white and crisp flesh. Per package, $5 \mathrm{c}$; oz., $20 \mathrm{c}$; $1 / 4 \mathrm{lb}$., $50 \mathrm{c}$; lb., $\$ 1.50$.
KLONDYKE. A variety very dark green when young, and medium early. Excellent quality for slicing. Per package, $5 \mathrm{c}$; oz., $20 \mathrm{c}$; $1 / 4 \mathrm{lb}$., $50 \mathrm{c}$; lb., $\$ 1.50$.

EARLY CLUSTER. A very productive variety, bearing its fruit in clusters of two or three. The fruit is short and very dark green and retains its fine dark color longer than other sorts. The fruits are uniform in size and shape. Very popular for shipping. size and shape. Very popular for shipping. Per $p$
$\$ 1.50$.

EXTRA EARLY GREEN PROLIFIC, or BOSTON PICKLING. A very prolific variety, used principally for pickles. Fruit medium sized, bright green, very even and symmetrical. Per package, $5 \mathrm{c}$; oz., 20c ; $1 / 4$ lb., $50 \mathrm{c}$; lb., $\$ 1.50$.

GHERKIN, or WEST INDIA GHERKIN. An extremely small fruited variety grown exclusively for pickles. It has no value for slicing. Is very prickly, but tender and crisp if pickled when young. Seed gercrisp if pickled when young, Seed ger-
minates slowly. Per package, 10c ; oz., 30c; $1 / 4$ lb., $\$ 1$; lb., $\$ 3$.

LONG GREEN. Our strain has been selected for extra length, and the cucumbers are a foot or more long. The seed cavity is small, and fruits are solid and of delicious quality. There is no finer table variety for slicing. Per package, $5 \mathrm{c}$; oz., $20 \mathrm{c}$; $1 / 4$ lb., $65 \mathrm{c}$; lb., $\$ 2$.

LEMON. This little cucumber is not half appreciated for the home garden. It has a appreciated for the home garden. It has a or unfit for the most and never gets bitter or unfit for the minst demanding taste. The
vines are prolific, the fruit is small and vines are prolific, the fruit is small and
always in good condition. Per package, $5 \mathrm{c}$; oz., $25 \mathrm{c}$; $1 / 4$ lb., $85 \mathrm{c}$; lb., $\$ 2.50$.

TELEGRAPH, ROLLINSON'S. ENGLISH GREENHOUSE VARIETY. These cucumbers are quite different from the ordinary sorts. They have very few seeds and very long, slender fruits, which are perfectly straight when grown suspended from vines in a when grown suspended from vines in a greenhouse. Very few seeds to a packet, but all are carefully saved from English greenhouses fro
only. Per package, $25 \mathrm{c}$.

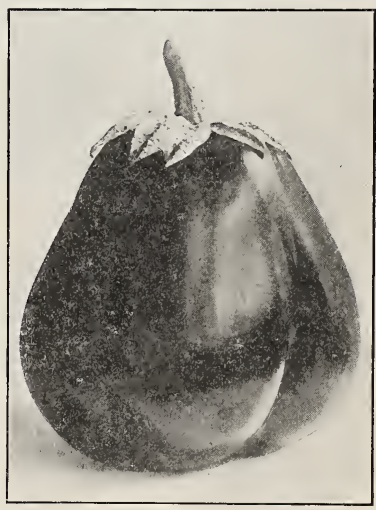

New York Improved Eggplant

\section{Egg-Plant}

The seed germinates slowly and should be started under glass, with moderately high temperature, about March 1. When about 3 inches high, transplant carefully to the garden or field, but not until all danger of frost is over. Egrplant flourishes in most of this state and wherever there is a good warm growing season.
BLACK BEAUTY. Rich purple black in color and a reinarkable market variety. Is early and makes also a fine sort for the home garden. Per package, 10c; $1 / 2$ oz., home garden. Per package, $10 \mathrm{c} ; 1 / 2$
$45 \mathrm{c}$; oz., $75 \mathrm{c} ; 1 / 4 \mathrm{lb} ., \$ 2.50 ; 1 \mathrm{~b}$., $\$ 7.50$.

NEW YORK IMPROVED LARGE PURPLE. The principal market variety. Plants are large and spreading, fruit large, and of a deep rich purple. Per package, $10 \mathrm{c}$; $1 / 2$ oz., $45 \mathrm{c}$; oz., $75 \mathrm{c}$; $1 / 4 \mathrm{lb}$., $\$ 2.50$; lb., $\$ 7.50$.

\section{Dandelion}

IMPROVED LARGE LEAVED. Much esteemed as a salad when blanched. Sow any time in drills 12 inches apart. Cover the seed very lightly. Per package, $10 \mathrm{c}$.

\section{Endive}

Sow any time in drills one foot apart; thin to about twelve inches; keep well cultivated and watered until developed. Blanch by gathering the leaves together and tying the ends in a conical form. The endive has a bitter flavor when not blanched.

BROAD LEAVED BATAVIAN (Scarolle). Plain broad leaves of light green color. Per package, $5 \mathrm{c}$; oz., $15 \mathrm{c}$; lb., $\$ 1.25$.

GREEN CURLED (Chicoree Frisee of the French). The most popular variety; dark with beautiful curled leaves. Per package, $5 \mathrm{c} ;$ oz., $20 \mathrm{c} ; 1 \mathrm{~b} ., \$ 2.00$.

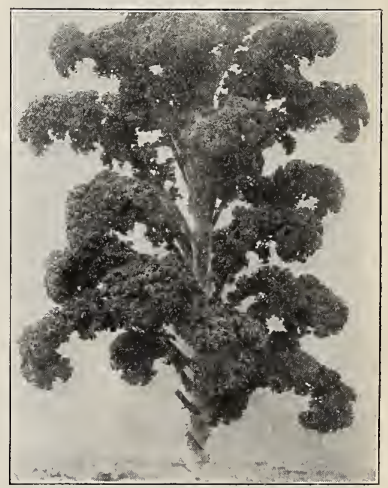

Curly Kale

\section{Kale or Borecole}

A species of cabbage, forming a mass of leaves, some varieties being very beautiful and curly. The leaves are cooked as greens. The seed should be planted in September, and the plants will be ready to use in the winter. It is hardy and will withstand frost and snow.

DWARF CURLED SCOTCH. Color bright green. Per package, $5 \mathrm{c}$; oz., $20 \mathrm{c}$; $1 / 4 \mathrm{lb}$., $65 \mathrm{c} ; \mathrm{lb} ., \$ 2$.

TALL GREEN CURLED SCOTCH. Grows about $2 \frac{x}{2}$ feet high. Is very curly and makes a beautiful plant. Quality of the best. Per package, $5 \mathrm{c}$; oz., 20c; 1/4 lb., $65 \mathrm{c} ; \mathrm{lb} ., \$ 2$.

JERSEY, or 1,000 HEADED. A tall variety with smooth leaves. Especially used for feeding chickens, furnishing lots of green feed. Per package, 5c; oz., 20c; $1 / 4$ lb., $45 \mathrm{c} ; 1 \mathrm{~b} ., \$ 1.25$. 


\section{Kohl Rabi}

A vegetable with the tops of cabbage and edible part. Sow in rows two feet apart and thin to one foot.

EARLY WHITE VIENNA. White and tender, very productive. Per package, $5 \mathrm{c}$; oz., $30 \mathrm{c} ; 1 \mathrm{~b} ., \$ 3$.

\section{Leek}

A very hardy and easily growu vegetable, resembling a green onion; much milder, however, and not so pronounced in flavor. May be sown alinost any time, in drills one foot apart; thin the plants to 10 inches apart.

AMERICAN FLAG. A very fine leek, with long, large stems, which are sweet and white when properly blanched; a vigorous grower. Per package, $5 \mathrm{c}$; oz., $35 \mathrm{c}$; $1 / 4 \mathrm{lb}$., $\$ 1.15 ; \mathrm{lb}$., $\$ 3.50$.

CARENTAN. The largest variety, though the stems are not so long as some others. Leaves are very broad. Per package, 5c ; oz, $35 \mathrm{c} ; 1 / 4 \mathrm{lb}$., $\$ 1.15 ; 1 \mathrm{~b} ., \$ 3.50$.

GIANT MUSSELBURGH. Thick long stems of sweet, mild flavor. Per package, 5c oz., $35 \mathrm{c}$; $1 / 4$ lb., $\$ 1.15 ; 1$ b., $\$ 3.50$.

\section{Lettuce}

Lettuce may be sown all the year round, but when it comes to July and August, extra precautions should be taken to have the seed come up. Rake the seed in well and cover very little with light sandy soil, then take some old burlap and lay on the ground, as we have advised in our garden calendar for the month of August, taking care to remove the burlap as soon as the seed comes up. Anyone desiring to raise lettuce, or, in fact, any other vegetable during the summer, can do so by providing themselves with some old burlap and when the seeds are up have some frames handy to shade the small plants, as the sun will burn them up the first day that the burlap is removed. The frames should be made of lath, cloth or burlap. A board may be set each side of the bed for the frames to rest upon. After the lettuce is a few days old, the frames and boards may be removed and new beds started. the roots of a turnip, the roots being the

To raise nice head lettuce, transplant the young plants fifteen inches apart each way. keep well watered, cultivated and free from weeds.

LOS ANGELES MARKET LETTUCE. The outside leaves are a deep green and slightly curled while the inside of the liead is pure white and very tirm it is crisp and un surpassed for our Southern California climate for the winter and spring market. The successful raising of lettuce depend upon the selection of the proper varieties at the proper time. Some dealers catalogue two strains of this lettuce; oue they call just "Wonderful" and the other "New York Special." WVe carry but one strain and we becial by actual test that this strain pro duces lettuce that is absolutely perfect. Visit our trial grounds and be your own judge. Per package, $5 \mathrm{c}$; oz., $35 \mathrm{c} ; 1 / 4 \mathrm{lb}$. $\$ 1.15 ; 1 \mathrm{~b}$., $\$ 3.50$.

BIG BOSTON. A popular light green cabbage variety, grown extensively for the market. Has a particularly tine golden buttery head, slightly tinged with brown. Also called "Trocadero" in Europe. Per package, $5 \mathrm{c}$; oz., $25 \mathrm{c}$; $1 / 4 \mathrm{lb} ., 85 \mathrm{c}$; lb., $\$ 2.50$

BLACK SEEDED SIMPSON. This is the popular variety of Black Seeded Lettuce in Southern California. Per package, 5c; oz., $20 \mathrm{c} ; 1 / 4 \mathrm{lb}$., 50c; lb., $\$ 1.50$.

CALIFORNIA CREAM B UTTER, OI ROYAL SUMMER CABBAGE. A popular variety for autumn and vinter use. Forms a large head, which is very buttery, and of a rich golden yellow inside. Per package, 5c; oz., 20c; $1 / 4 \mathrm{lb}$., 50c; lb., $\$ 1.50$

EARLY CURLED SIMPSON. A loose bunching sort, forming no definite head. Is crisp and tender; light green in color. Very oz., 20c; $1 / 4$ lb., 50c; lb., $\$ 1.50$.

HANSON. A fine, large heading variety. Leaves curled on the edges, light yellowish green in color. The head is crisp and brittle and flavor is excellent. The very best home garden variety in existence, and much the best variety of its class. Allow 12 inches for each head. Per package, $5 \mathrm{c}$; oz., $20 \mathrm{c}$; $1 / 4 \mathrm{lb}$., 50c; lb., $\$ 1.50$.

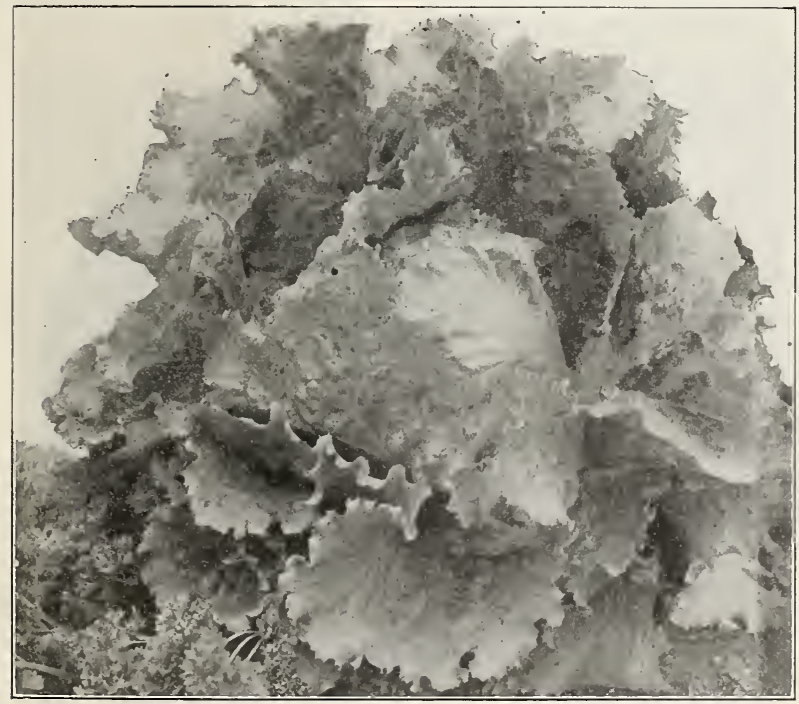

Los Angeles Market Lettuce

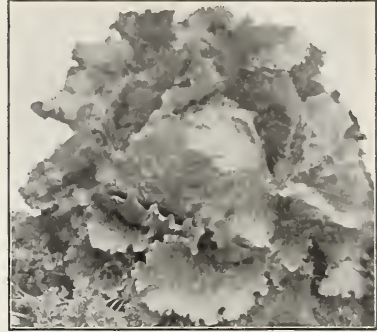

Iceberg

ICEBERG. A large, crisp lettuce, always tender. Iceberg stands hot weather remarkably well and is usually sown early in August for fall use. Give each head 15 inches in a row. The color is light green, lightly tinged with brown. Try this either for home or market garden. Per package, $5 \mathrm{c} ;$ oz., $25 \mathrm{c}$; $1 / 4$ lb., $85 \mathrm{c}$; lb., $\$ 2.50$.

PRIZEHEAD. One of the very best loose bunching or non-heading varieties. Leaves brown, very curly, and of remarkably fine flavor. Grows quickly and all except the outer row of leaves are very brittle. It is probably the most easily grown lettuce. Per package, 5c; oz., 20c; 1/4 lb., 50c; lb. $\$ 1.50$

WHITE PARIS COS. The best Cos or celery varieties. Forms a large, light green plant with the head well folded and quite solid. Cos lettuce is also called Romaine, and is very popular with our foreign population, and it is highly prized in England and France. The Cos type of lettuce has long, upright leaves with heavy straight midribs. The flavor is different from ordinary lettuces and estemed by many. Either tie the plants to blanch them or plant them closely, 5 inches apart. Per package, $5 \mathrm{c}$; oz., $20 \mathrm{c}$; $1 / 4$ lb., $60 \mathrm{c}$; 1b., $\$ 1.75$.

\section{Cantaloupes}

Southern California has an ideal climate for growing of muskmelons and watermelons. Of semi-tropical habits, they grow best in light, warın soil. Plant when the danger of frost has passed, in hills six feet apart each way; thin out to three or four strong plants with ashes, plaster or tobacco to protect them from insects.

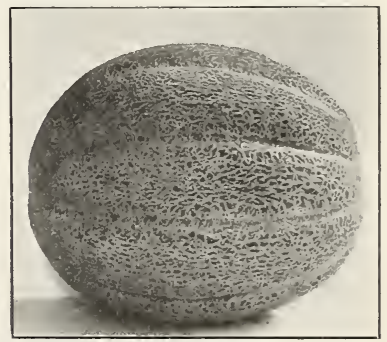

Burrell's Gem

BURRELL'S GEM or DEFENDER. The best bright orange fleshed melon. The seed cavity is small and the flesh is colored clear to the rind; deeply netted; flavor equal to the best of any. Per package, $5 \mathrm{c}$; oz., $20 \mathrm{c}$; $1 / 4$ lb., 50c; lb., $\$ 1.50$. 
EMERALD GEM. Per package, 5c; oz., $20 \mathrm{c} ; \mathrm{I} / 4 \mathrm{lb} ., 50 \mathrm{c} ; 1 \mathrm{~b} ., \$ 1.50$.

EXTRA EARLY HACKENSACK. Per pack age, $5 \mathrm{c}$; oz., $20 \mathrm{c}$; $1 / 4$ lb., $50 \mathrm{c}$; $1 \mathrm{~b}$., $\$ 1.50$.

GOLD LINED ROCKY FORD. Of a fine uniform shape and without ribs; slightly oval; meat thick, light green, with a light golden yellow rim. Flesh very sweet and spicy. There is no better melon than this. Per package, $5 \mathrm{c}$; oz., $25 \mathrm{c}$; $1 / 4$ 1b., $75 \mathrm{c}$; $1 \mathrm{~b}$. $\$ 2.25$.

GREENLEY WONDER or INDIANA Large, globular, salmon-fruited variety, heav ily netted and ribbed; excellent flavor. Per package, $5 \mathrm{c}$; oz., $20 \mathrm{c}$; $1 / 4 \mathrm{lb}$., $60 \mathrm{c}$; $1 \mathrm{~b} ., \$ 1.75$. HACKENSACK or TURK'S CAP. The flavor is sweet and delicious, with green flesh. Has flattened ends, thick irregular ribs and coarse netting. Per package, $5 \mathrm{c}$; oz., $20 \mathrm{c}$ $1 / 4 \mathrm{lb}$., $50 \mathrm{c}$; lb., $\$ 1.50$.

MONTREAL MARKET. One of the finest. Flesh firm and sweet; texture the best. Per package, $5 \mathrm{c}$; oz., $20 \mathrm{c}$; $1 / 4$ lb., $60 \mathrm{c}$; $1 \mathrm{~b} ., \$ 1.75$.

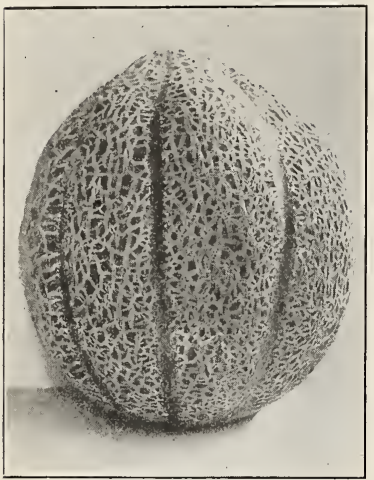

Rockyford

PERSIAN. Hybrid Muskmelon. This is a large melon, from 8 to 10 inches in diameter, and is heavy for its size. The melons are heavily netted, and are globular. Its color is bright orange. The flavor is different from other melons, and comes out delight fully when the melons are well ripened. Should not be eaten until fully ripe. It is undoubtedly the finest of all muskmelons. Per package, 10c; oz., 60c; $1 / 4$ lb., $\$ 2$; lb., $\$ 6.00$.

ROCKY FORD or NETTED GEM. Grown in great quantities for the market. Fruit is slightly oval, finely netted, and slightly ribbed. Flesh thick, green and of fine qual ity, spicy, very sweet flavored. Rocky ity, spicy, very sweet flavored. Rocky
Fords are small to medium sized. Other Fords are small to medium sized. Other
melons too big to ship for market are often preferred for home gardens. Per package, $5 \mathrm{c}$; oz., $20 \mathrm{c}$; $1 / 4 \mathrm{lb}$., $50 \mathrm{c}$; ib., $\$ 1.50$.

TIP TOP. One of the best known of the deep yellow or salmon-fleshed varieties. The fruits are large, nearly round, slightly ribbed and lightly netted over a light slaty skin; very highly musk-flavored, which many people prefer in a melon. Per pack age, $5 \mathrm{c}$; oz., $25 \mathrm{c}$; $1 / 4$ lb., $85 \mathrm{c}$; $1 \mathrm{~b}$., $\$ 2.50$.

COLUMBUS. One of the favorite greenfleshed varieties of the Los Angeles market. It is different from most melons, in that it is perfectly round without ribs. The skin of the ripe melon is of a beautiful shade of light tan and is covered with thick and
light colored netting. The flesh is very light colored netting. The flesh is very
solid and thick, leaving only a small seed cavity. One of the best shipping varieties. Per package, $5 \mathrm{c}$; oz., $10 \mathrm{c}$; lb., $\$ 1.00$.

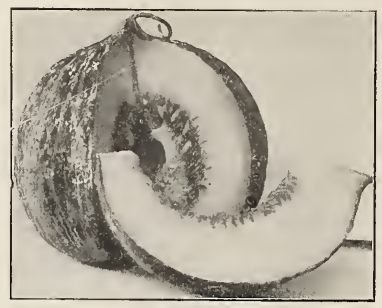

Golden Beauty Casaba

\section{Casaba}

HONEY DEW. These melons, well ripened on the vine, have a delicious flavor and are greatly improved by adding a little lemon juice when eating. The flesh is light emerwhite, turning to creamy yellow when ripe. White, turning to creamy yellow when ripe.
The melons slip from the vine when ripe and may be picked just before ripening and stored in a cool place for two months. Per package, $5 \mathrm{c}$; oz., $25 \mathrm{c}$; $\pi / 4$ b., $85 \mathrm{c}$; lb., $\$ 2.50$. GOLDEN BEAUTY. Early fruits ripen continuously from. July until frost comes. Golden Beauty is bright yellow, globular in shape, with wrinkled skin and slightly pointed at stem end. Flesh is pure white and very thick. Per package, $5 \mathrm{c}$; oz., $25 \mathrm{c}$; $1 / 4$ lb., 85c; lb., $\$ 2.50$.

WINTER PINEAPPLE. A fine, late ripening, long keeping variety. The fruits are very solid and heavy, about 10 to 12 inches in diameter. The color is deep mottled sea $85 \mathrm{c} ;$ lb., $\$ 2.50$.

IMPROVED HYBRID CASABA. Deep green and heavily ribbed, of medium size; flesh thick and of a fine quality. Per pack age, $5 \mathrm{c}$; oz., $25 \mathrm{c}$; $1 / 4 \mathrm{lb}$., $80 \mathrm{c}$; 1b., $\$ 2.50$.

SANTA CLAUS. A very late variety. Oblong mottled yellow and green, flesh light green and of rich flavor. Per package, $5 \mathrm{c}$; oz., $25 \mathrm{c}$; $1 / 4$ lb., $80 \mathrm{c}$; 1b., $\$ 2.50$. ald green and the color of the skin nearly green. Per package, $5 \mathrm{c}$; oz., $25 \mathrm{c} ; 1 / 4 \mathrm{lb}$.

\section{Watermelon}

Light, sandy or gravelly soil is necessary for the best watermelons. They seldom do well on heavy adobe or clay soils, and these lands should be avoided when growing watermelons as a farm crop. In the garden, any soil can be made suitable by spading in each hill some well rotted manure and sand or loam.

Plant the seed about the middle of May, in hills about 8 feet apart. Use five or six seeds to a hill and thin out to three plants as soon as the second or third leaf shows. Use about four ounces of seed to 100 hills, or as a farm crop, two to four pounds per acre. A good watermelon is one of the finest fruits on earth. On a hot day there is nothing like a fresh, juicy, sweet watermelon. Some watermelons are much sweeter than others. There is no use in buying an old sort
are familiar with the name. for the home garden or shipping. The skin is very dark green, and flesh is bright red and of delicious quality. Soak seed in water an hour or two before planting to increase germination. (Important only for Angelino and Chilian.) Per package, 5c; oz., 20c; $1 / 4$ 1b., 50c; 1b., $\$ 1.50$.

BLACK SEEDED ANGELINO. Many prefer a melon with black seeds. This variety has all of the good points of Angelino, bright red flesh, exceedingly sweet in flavor and of fine texture. Large melon. Per package, $5 \mathrm{c}$; oz., 20c; $1 / 4 \mathrm{lb} ., \$ 50 \mathrm{c}$; $1 \mathrm{~b}$. , $\$ 1.50$.

CHILIAN, WHITE SEEDED. Description same as Angelino, except for color of skin, which is a deep green with slightly darker stripes. Two of our best melons. Per package, $5 \mathrm{c}$; oz., $20 \mathrm{c}$; $1 / 4 \mathrm{lb}$., $50 \mathrm{c}$; 1b., $\$ 1.50$.

CHILIAN, BLACK SEEDED. Some people think a melon does not taste right unless it has black seed, and certainly they sell better at restaurants, etc. Has all of the splendid qualities of White Seeded Chilian and if anything is a trifle earlier. Per package, 5c; oz., 20c; $1 / 4 \mathrm{lb}$., 50c; $1 \mathrm{~b} ., \$ 1.50$.

KLECKLEY SWEETS or MONTE CRISTO. A very desirable variety for the home garden or nearby market. Fruit medium sized and oval. Per package, 5c; oz., $20 \mathrm{c}$; $1 / 4$ lb., $45 \mathrm{c}$; $1 \mathrm{~b}$., $\$ 1.25$. use in buying an old sort just because you

ANGELINO. A good all round melon, either

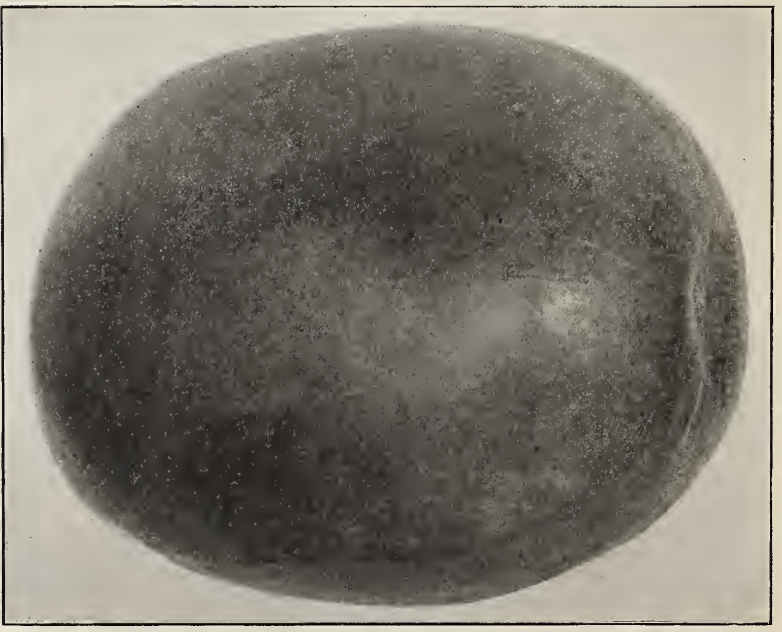

Angelino Black Seeded 
THE NEW TOM WATSON WATERMELON. This large dark green watermelon often weighing 50 to 60 pounds and averaging on good soil over 30 pounds, has in a few years taken place among the first. The flesh is deep red and contains very few seeds firmly bedded; is a good shipper and yields a heavy crop. Our seed is grown for us in the South, where this melon originated and is of the best to be had. Your orders should be sent in early as the de. mand will be heavy. Per package, $5 \mathrm{c}$; oz, $10 \mathrm{c} ; 1 \mathrm{~b} ., \$ 1.00$.

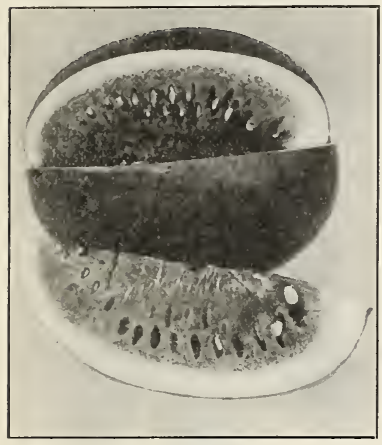

Tom Watson

GEORGIA RATTLESNAKE. One of the oldest and formerly most popular sorts, and frequently known as "Gypsy." A large, oblong variety, with decided stripes of light and deep green. Rind is tough, but flesh is of medium quality and bright pink. A good shipping and market melon. Per package, $5 \mathrm{c}$; oz., 20c; $1 / 4 \mathrm{lb}$., 5c; 1b., $\$ 1.25$.

KLONDIKE. Best local variety, good ship. per. Very large size. In great demand in Los Angeles markets. Per package, 5c oz., 20c; lb., $\$ 2.50$.

\section{Mustard}

SOUTHERN CURLED. Producing enor mous bunches of green leaves; excellent for greens. Cultivated extensively in the South. Per package, $5 \mathrm{c}$; oz., 10c; lb., $\$ 1.00$.

NEW CHINESE CURLED. A large grow ing kind grown by the Chinese market gar deners; generally very productive. Per package, $5 \mathrm{c} ; \mathrm{oz}$., $10 \mathrm{c}$; lb., $\$ 1.25$.

\section{Okra}

The seed pods resemble a green pepper only they are ribbed. Used in soups and stews. Sow as soon as the weather is warm enough, in drills two inches deep and three inches apart; keep well cultivated, hilling up when the plants are about a foot high.

WHITE VELVET. A favorite variety in the south and in California. Pods are large, slightly ribbed, remain tender a long time, are of good quality. Per package, 5c; oz. $10 \mathrm{c} ; 1 \mathrm{~b}$., $\$ 1.00$.

EARLY DWARF, A good market variety pods long and smooth. Per package, 5c; oz., 10c; lb., \$1.00.

\section{Garlic}

IMPROVED RED ITALIAN. Recommended highly for its keeping qualities. An excellent variety. $30 \mathrm{c}$ per $1 \mathrm{~b}$.

\section{Citron}

RED SEEDED. Unexcelled for stock feed. Per package, $5 \mathrm{c}$; oz., $20 \mathrm{c}$; $1 / 4$ lb., $45 \mathrm{c}$ lb., $\$ 1.25$.

GREEN SEEDED, or COLORADO PRESERVING. Per package, 5c ; oz., $15 \mathrm{c}$; $1 / 4$ lb., $35 \mathrm{c}$; lb., $\$ 1$.

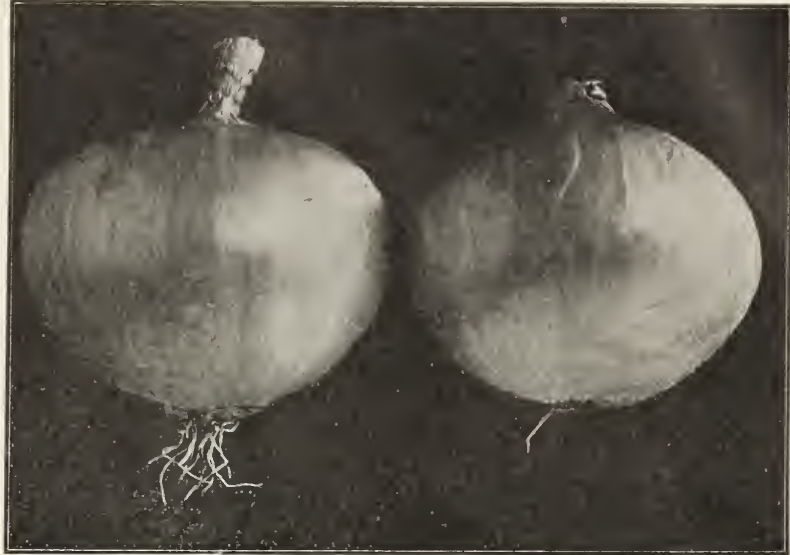

Prizetaker Onions

\section{Onion Seed}

For general crop, the seed must be sown during the month of January or before February 1 , and, if the location is a fairly dry one, it is best to sow about the middle of December. The seed should be sown with a seed drill, in rows 1 inches apart, using four to five pounds of seed per acre. In very to five pounds of seed per acre. In very weedy land the rows may be 18
apart, when less seed is required.

California grows one-sixth of the onion crop for the entire United States. Most of the onion seed for the country is produced here in California. Our firm specializes in onion seed. Write us for prices on larger THE FAMOUS RIVERSIDE SWEET SPANISH ONION. The unusual mildness and excellent flavor has made this variety remarkably popular, and the demands for it is large in the vegetable markets all over the United States. It is a good keeper, large, thin straw-colored skin, and so mild that it can be eaten like an apple. This onion commands the highest price in the onion commands the highest price in the first of February, and will mature in Aug. first of February, and will mature in Aug.
ust. It was introduced from Spain four years ago, and is the mildest Spanish onion known. Seed is scarce, but it will be profitable to the grower who plants this variety. Per package, $15 \mathrm{c} ; 1$ oz., $\$ 1.25$; 1/4 lb., $\$ 3.50$; 1 lb., $\$ 12.00$

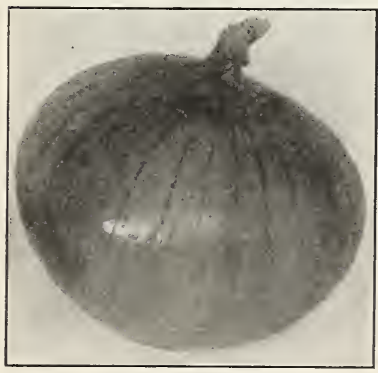

Riverside Sweet Spanish
AILSA CRAIG. Color light yellow; grail fine; flavor mild; ripens early. Ailsá Crai is the largest onion grown; often weighs 2 pounds. Per package, 5c; oz., $50 \mathrm{c}$; 1/4 lb., $\$ 1.65$; 1b., $\$ 5$.

AUSTRALIAN BROWN. Early and ver hard variety which does especially well in California. The skin is thick and the colo is of rich brown. Is especially noted as a long keeper, as it keeps well into spring without sprouting or shriveling, and much longer than other varieties. Per package, $5 \mathrm{c}$; oz., 20c; $1 / 4$ lb., 60c; lb., $\$ 1.75$.

CRYSTAL WHITE WAX. The beautiful clear white Bermuda onion, seen in our markets in crates early in spring is this variety. Mild and sweet. Per package, $5 \mathrm{c}$ oz., $50 \mathrm{c}$; $1 / 4$ lb., $\$ 1.65$; lb., $\$ 5$.

EXTRA EARLY RED FLAT. A very early, flat variety, with dark purplish red skin. Forms a hard bulb; keeps well. Per package, $5 \mathrm{c}$; oz., $25 \mathrm{c}$; $1 / 4$ lb., $85 \mathrm{c}$; lb., $\$ 2.50$.

MAMMOTH SILVER KING. An early, large, white, flat onion; does not keep well Per nackage, $5 \mathrm{c}$; oz., $40 \mathrm{c} ; 1 / 4$ lb., $\$ 1.35$ lb., $\$ 4$.

WHITE PORTUGAL or SILVERSKIN The best known and most largely used white onion. Is flat on the bottom and thick toward the top. Very hard and firm. An excellent keeper. Is largely used for white onion sets as well as for bulbs for the best market trade and also for pickles. Per package, $5 \mathrm{c}$; oz., $35 \mathrm{c} ; 1 / 4$ lb., $\$ 1.25$; lb., $\$ 3.50$.

YELLOW GLOBE DANVERS. Our strain of Globe Danvers is especially selected on our farms to give an even ripening crop The bulbs are all of fairly large size, small at the neck, perfectly and regularly formed. Yellow Globe Danvers is the most popular onion for market and for shipping. Is almost ball shaped but a trifle flattened at both ends. It is a heavy cropper and a good firm variety. Per package, $5 \mathrm{c}$; oz. $25 \mathrm{c} ; 1 / 4 \mathrm{lb} ., 85 \mathrm{c}$; lb., $\$ 2.50$.

PRIZETAKER (Denia Onion). A remarkably large onion. Skin light yellow; flesh sweet; flavor mild. Not a long keeper, but yields enormously; globe shaped. Per package, $5 \mathrm{c} ;$ oz., $25 \mathrm{c}$; $1 / 4$ lb., $85 \mathrm{c}$; lb., $\$ 2.50$.

RED BERMUDA. Bulbs are of pinkish straw color A companion to White Bermuda, which see for description. Per package, 5c; oz., 30c; $1 / 4$ lb., $\$ 1$; lb., $\$ 3$. 
RED WEATHERSFIELD. The best known and most widely used red variety. In shape it is flattish, but thick, with very firm flesh. Is hard and an excellent keeper, as well as a heavy cropper. The color is a bright pur a heavy cropper. The color is a bright pur-
plish red. Per package, $5 \mathrm{c}$; oz., $25 \mathrm{c} ; 1 / 4$ lb., $85 \mathrm{c}$; lb., $\$ 2.50$.

SOUTHPORT WHITE GLOBE. The best pure white globe shaped variety. Forms handsome hard onions with wax-like flesh. Per package, 5c; oz., 35c; $1 / 41 \mathrm{~b} ., \$ 1.25$; 1b. $\$ 3.50$.

SOUTHPORT YELLOW GLOBE. A fine, orange-yellow, globe shaped variety, of best keeping and shipping quality. Per package, $5 \mathrm{c} ;$ oz., 30c; $1 / 4$ lb., $\$ 1 ; 1 \mathrm{~b} ., \$ 3$.

WHITE BERMUDA. A very early southern market onion. Flavor is mild and sweet. The bulbs are pinkish straw and flat shaped. We offer true Canary Island grown seed, the best. Per package, $5 \mathrm{c}$; oz., $40 \mathrm{c} ; \mathrm{r} / 4 \mathrm{lb}$. $\$ 1.35 ; 1 \mathrm{~b} ., \$ 4$.

WHITE QUEEN. A very early white onion. Rather small and does not keep well. Is of fine, mild flavor, and largely used for home made pickles. Per package, $5 \mathrm{c}$; oz., $40 \mathrm{c}$ I $/ 4$ lb., $\$ 1.35 ; 1$ lb., $\$ 4$.

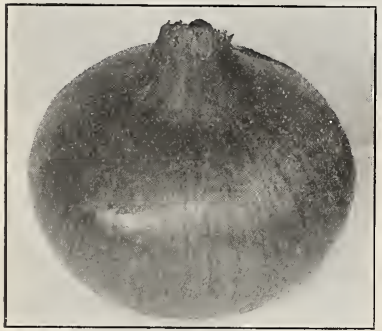

Southport White Globe

YELLOW DANVERS. This is the best known and the most generally used flat, yellow onion. It is extra hardy and a very heavy yielder. Color bright orange yellow; flesh white and firm. A good keeper, fairly flesh white and firm. A good keeper, fairly variety for transplanting to get early onions. One of the standard varieties on the San Francisco market. Per package, $5 \mathrm{c}$; oz., $20 \mathrm{c} ; \mathrm{I} / 4 \mathrm{lb} ., 60 \mathrm{c}$; lb., $\$ 1.75$.

\section{Onion Sets}

BROWN OR YELLOW, September to May. 20 c per lb.; by mail, $25 \mathrm{c}$.

ONION MULTIPLIERS. 30c per $1 \mathrm{~b}$.; by mail, $35 \mathrm{c}$.

SHALLOTS. $30 \mathrm{c}$ per $1 \mathrm{~b}$; by mail, $35 \mathrm{c}$.

\section{Parsley}

Sow all the year round in drills 1 inch deep and $11 / 2$ feet apart; grows in deep rich soil DOUBLE CURLED. Fine for garnishing and for flavoring. Per package, 5c; oz., $15 \mathrm{c} ; \mathrm{lb} ., \$ 1.50$.

PLAIN LEAVED PARSLEY. An old variety preferred by many to the curled on account of its fine flavor. Per package, $5 \mathrm{c} ;$ oz., $15 \mathrm{c} ; 1 \mathrm{~b} ., \$ 1.25$.

HAMBURG or TURNIP ROOTED. A plain leaved variety, forming a large, thick edible root. Per package, $5 \mathrm{c}$; oz., $20 \mathrm{c}$; $1 / 4 \mathrm{lb}$., $50 \mathrm{c} ; 1 \mathrm{~b} ., \$ 1.50$.

\section{Parsnips}

Sow early in the season in rich loam in drills $1 / 2$ inch deep and 15 inches apart; cover the seeds with extra light soil, as they have some difficulty in coming through the ground if it is a trifle heavy,

HOLLOW CROWN. The standard variety for home or market use. Per package, $5 \mathrm{c}$; oz., $15 \mathrm{c}$; 1b., $\$ 1.25$.

\section{Peas}

Will grow in almost any soil. Well decomposed stable manure and bone dust are excellent fertilizers. For peas, deep plowing is essential. Plant them almost all the year round, taking a well drained soil and sunny exposure for winter peas. Usually they are planted in double rows four feet apart and planted in double

AMERICAN WONDER. A dwarf or short vine variety, growing about 12 inches tall bearing short, well filled pods, very early. Per package, 10c ; lb., 40c ; 10 lbs., \$3.50.

FIRST AND BEST or EXTRA EARLY Grows 2 to $21 / 2$ feet high. Seed yellowish white and round; pods straight, short and well filled. Quality good for a smooth seeded variety. Per package, 10c; 1b., 40c ; 10 lbs., $\$ 3.50$.

LAXTONIAN. This is an ideal market and home garden pea, medium dwarf in habit of growth, but with very large pods, averaging 5 to 6 inches in length. Laxtonian seldom has any blank spaces in the pods. Per package, $10 \mathrm{c}$; 1b., $40 \mathrm{c}$; 10 lbs., $\$ 3.50$.

GRADUS or PROSPERITY. Has the finest flavored peas of all. Tall, light vine, matures early. Peas and pods large size ; eight to ten peas in a pod. Per package, $10 \mathrm{c}$; 1b., $40 \mathrm{c} ; 10$ lbs., $\$ 3.50$.

THOMAS LAXTON. A fine, early, tall va riety, similar to Gradus, but more hardy and not quite so early. Has large, blunt end pods, that fill well with peas of finest quality. Per package, $10 \mathrm{c}$; 1b., $40 \mathrm{c} ; 10 \mathrm{lbs}$. $\$ 3.50$.

ALDERMAN. A pea similar to Telephone, but more prolific The vine is extra vigorous and the pods are dark green and always well filled with fine large peas. This is the very finest and best pea of this class. Per package, 10c; 1b., 40c; 10 lbs., $\$ 3.50$.

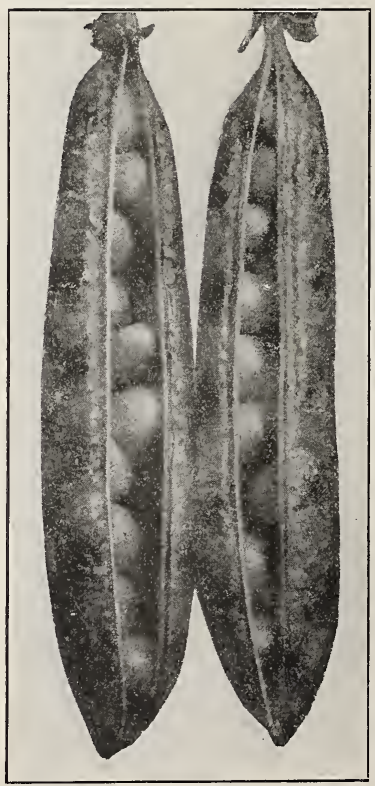

Alderman Peas
ABUNDANCE. Per package, 10c ; lb., 40c ; 10 lbs., $\$ 3.50$.

McLEAN'S ADVANCE. Per package, $10 \mathrm{c}$; lb., 40c; 10 lbs., $\$ 3.50$.

DAISY or DWARF TELEPHONE. We can highly recommend the Daisy for fall planting. Height, about 2 feet, and vines com. pletely covered with large, full bearing pletely covered with large, full bearing
pods. Does extremely well in California. pods. Does extremely well in California.
Per package, 10c; 1b., 40c; 10 lbs., $\$ 3.50$.

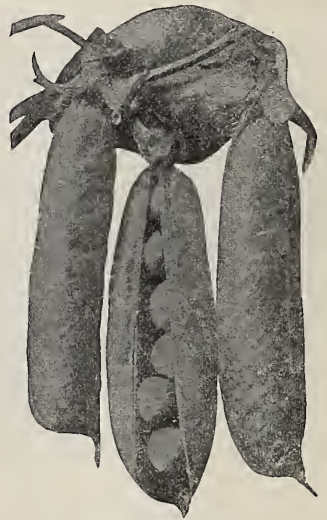

Dwarf Telephone

CHAMPION OF ENGLAND. An old favorite. Very late; vine very tall and strong. Pods moderate size. Per package, 10c; Ib., $40 \mathrm{c} ; 10$ lbs., $\$ 3.50$

IMPROVED SENATOR. Per package, $10 \mathrm{c}$; lb., $40 \mathrm{c}$; 10 lbs., $\$ 3.50$.

MELTING SUGAR or EDIBLE POD. A tall variety bearing large, flat brittle pods. These are sweet and are cut or broken and cooked like string beans. Is a delicious vegetable and should be better known and more generally used. Per package, 10c; 1b., $40 \mathrm{c} ; 10$ lbs., $\$ 3.50$.

EARLY SNOWDROP. Per package, 10c; 1b., 40c; 10 lbs., $\$ 3.50$.

STRATAGEM. A semi-dwarf variety with large leaves and large pods. The vines bear well and the pods are long, thick, deep green and well filled. This variety has a tendency to run out or revert to a small podded type, and many stock of Stratagem podered type, and many stock of Stratagem We offer an especially fine strain, free from We offer an especially fine strain, free from
small pods. Our re-selected strain. Per package, 10c; 1b., 40c; 10 lbs., $\$ 3.50$.

TELEPHONE. Is tall and large; wrinkled peas of fine quality; large pods. Foliage is of pale green color and quality of the very best. Per package, 10c; 1b., 40c; 10 lbs., $\$ 3.50$.

YORKSHIRE HERO or A L A M D A SWEETS. A very hardy and prolific, semidwarf, late, wrinkled variety. The peas are large and of fine quality. Per package, $10 \mathrm{c}$; lb., $40 \mathrm{c} ; 10$ lbs., $\$ 3.50$.

\section{Peppers}

There are varied uses for the peppers, and while they are more popular in the Sout among the Spanish and Mexican people, they are used very largely by all who like strong, hot condiments. The several varieties are used for stuffing, when green for pickles, for pulverizing when dry, and for soups, etc pulverizing when dry, and for soups, etc. the variety, one hot and one sweet. 
Peppers do best in hot climates, but can be grown quite successfully in nost places of any ordinary soil. The seed germinates slow. ly and should be started in hoves. and the young plants transplanted after all danger of frost is over. Set in 18 inch rows.

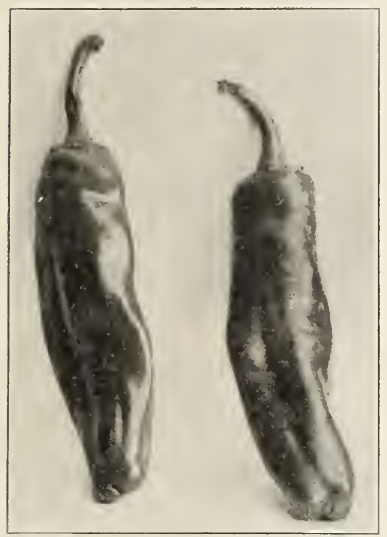

Anaheim Chili

ANAHEIM CHILI. This pepper is largely grown in Orange County, and is used dried and for canning. It is long, 7 inches or so, nedium sized in width, and is thick fleshed. The flavor is mild for a chili pepper and The flavor is mild for a chili pepper and
liked by Mexicans and Americans alike. Per package, 5c; oz., $50 \mathrm{c}$; $1 / 4$ lb., $\$ 1.65$; lb., $\$ 5$.

CHINESE GIANT. A very large, deep red variety, very thick and blunt. It is fully twice as large as Large Bell, or Bull Nose, being four to fire inches thick at the top and about 6 inches long. Plants are not prolific bearers. Per package, 5c; oz., 80c; 1/4 lb., $\$ 2.70 ; 1 b ., \$ 8$.

MEXICAN CHILI. In a class by itself, on account of its extreme pungency. Per package, $5 \mathrm{c}$; oz., $50 \mathrm{c}$; $1 / 4$ lb., $\$ 1.65 ; 1 \mathrm{~b} ., \$ 5$.

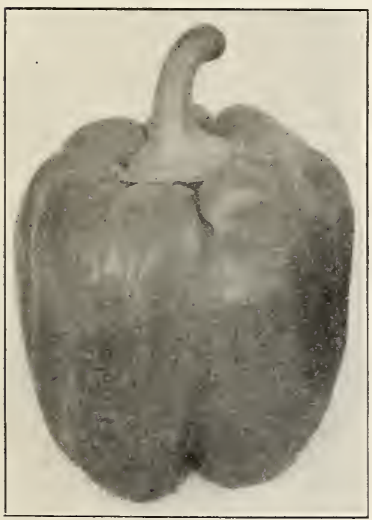

Chinese Giant
LARGE BELL or BULL NOSE, Fruit large, round and blocky, and about 3 inche long and two inches thick. The color is deep green when fruit is young, but when fully ripened it is a rich, glossy blood-red. Plant grows about 2 feet high. Per package, $5 \mathrm{c}$; oz., $70 \mathrm{c} ; 1 / 4$ lb., $\$ 2.35 ; \mathrm{ib}, \$ 7$.

LONG RED CAYENNE. A strong, pungent variety, having long pointed fruit, which is bright scarlet when ripe. A well know's and popular variety. Per package, $5 \mathrm{c} ; \mathrm{cz}, 80 \mathrm{c}$; $1 / 4$ lb., $\$ 2.70$; lb., $\$ 8$.

PIMIENTO. This is a sweet pepper good for salads, either fresh or canned. Used largely by canners and market gardeners. Very thick flesh; mild flavor. Per package, $5 \mathrm{c} ;$ oz., 60c; $1 / 4$ lb., $\$ 2$; lb., $\$ 6$.

RED CHILI. A rather small, bricht red variety, about 2 inches long and pointed. The pods are used in making chili sauce, and very pungent and hot. Per package, $5 \mathrm{c}$; oz., $80 \mathrm{c}$; $1 / 4$ lb., $\$ 2.70 ; 1 \mathrm{~b} ., \$ 8$.

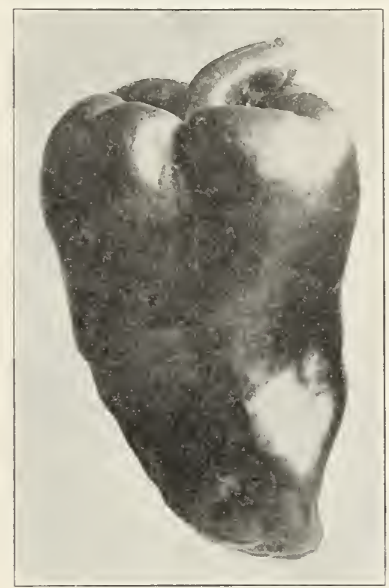

Ruby King

RUBY KING. A popular variety of the Bell or Bull Nose type. The fruit is large, dark green while young, turning to bright glossy red when ripe, and the flavor is mild and sweet. A desirable variety for slicing in salads and for stuffing. Per package, 5c ; oz., 70c; $1 / 4$ 1b., $\$ 2.35$; 1b., $\$ 7$.

SWEET MOUNTAIN or SPANISH MAM. MOTH. It is a late variety, bearing large thick fruit, which is frequently 8 inches long and 2 to 3 inches in diameter. When mature it is a deep glossy red, and the mature it is a deep glossy red, and the flavor is mild and sweet. Per
oz., $70 \mathrm{c} ; \mathrm{r} / 4 \mathrm{lb}, \mathrm{l}, \$ 2.35 ; 1 \mathrm{~b} ., \$ 7$.

SWEET UPRIGHT. A large thick variety, with mild, sweet flesh. Per package, 5c oz., $80 \mathrm{c} ; 1 / 4$ lb., $\$ 2.70 ; 1 \mathrm{~b} ., \$ 8$.

\section{Pumpkins}

Plant early in the season in hills eight feet each way; thin out to three or four strong plants; keep them from any other vining plants, such as melons, for they are apt to plants, such as

CALIFORNIA FIELD. The well-known, or dinary pumpkin, largely used for stock feeding. The fruit is variously colored, in yellow, drab, red and orange, and varies also in size, but is usnally very large. Is a heavy cropper and very early grown. Per ivite for prices on larger quantities.
CONNECTICUT FIELD. A fine, large, orange colored variety used for field culture and stock feeding. The skin is smooth and ribbed and the flesh is brittle and sweet Per package, $5 \mathrm{c}$; oz., $20 \mathrm{c}$; $1 / 4$ lb., $45 \mathrm{c}$; lb. $\$ 1.25$.

LARGE CHEESE or KENTUCKY FIELD. a large, flattened pumpkin, averaging about 2 feet through. When ripened the skin is a rich crean color. Flesh yellow and of fine quality. Some customers claim that fine quality. Some customers claim that
this variety is not susceptible to the ravages of the squash bug. 1'er package, $5 \mathrm{c}$; oz. $20 \mathrm{c} ; 1 / 4$ lb., $45 \mathrm{c}$; lb., $\$ 1.25$.

MAMMOTH GOLDEN CUSHAW. One of the best stock feeding pumpkins. Is solid, yellow crookneck sort and is nearly all flesh, having a very small seed cavity. Per pack age, $5 \mathrm{c}$; oz., $20 \mathrm{c}$; $1 / 4$ lb., $60 \mathrm{c}$; 1b., $\$ 1.75$.

GREEN STRIPED CUSHAW. Mammoth heavy yielding cattle pumpkin, used largely in the San Joaquin Valley. 1'er package, $5 \mathrm{c}$; oz., $20 \mathrm{c}$; $1 / 4$ lb., $45 \mathrm{c}$; 1b., $\$ 1.75$.

MAMMOTH KING or POTIRON. Skin reddish yellow in color, and flesh rich orange. It runs very uniform in shape and color, and all are of immense size. Per package, $5 \mathrm{c}$; oz., 20c; $1 / 4$ 1b., $60 \mathrm{c}$; 1b., $\$ 1.75$.

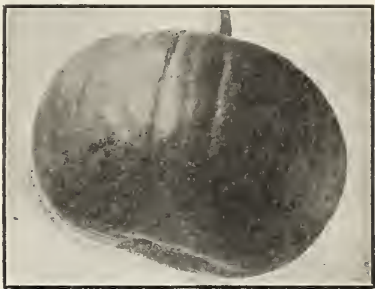

Sugar or New England Pie Pumpkin

PIE PUMPKIN. A small, round yellow sort with fine, pinkish netting. Flesh is thick, sweet and of excellent quality. Per pack age, $5 \mathrm{c}$; oz., $20 \mathrm{c}$; $1 / 4$ lb., $45 \mathrm{c}$; lb., $\$ 1.25$.

SMALL SUGAR or NEW ENGLAND PIE. A small round pumpkin of excellent quality. The flesh is rich yellow, very thick and sweet, and the skin is dep orange. We recommend this variety as the best for pies. Per package, $5 \mathrm{c}$; oz., $20 \mathrm{c}$; $1 / 4$ lb., $45 \mathrm{c}$; lb., $\$ 1.25$.

\section{Rhubarb}

Rhubarb when grown in good, rich soil, will produce enormous stalks in great profusion, especially during the first two years. When the plants are two years old, it is advisable to dig them up, separate them and reset them in another part of the garden, using soil that in another part of the garden, using soil that vance.

PANAMA RHUBARB. Average stem is 11 feet long and weighs $1 / 4 \mathrm{lb}$. This splendid Rhubarb sends up its stalks very early, like the Crimson Winter from which it is derived. The stalks are double the size of the Crimson Winter, which they otherwise resemble. Roots, 35c each; dozen, $\$ 3.50$.

CRIMSON WINTER. A variety of fine flavor. Produces small, crimson stems very early in winter and spring and continues bearing till late. Per package, $15 \mathrm{c}$; oz., $\$ 1.50 ; 1 / 4$ lb., $\$ 5 ;$ lb., $\$ 15$.

MYATT'S VICTORIA. A very large, late variety with green stalks. It comes fairly true from seed. Per package, $10 \mathrm{c}$; oz., $20 \mathrm{c}$; $I / 4$ lb., $50 \mathrm{c} ; \mathrm{lb} ., \$ 1.50$.

STRAWBERRY RHUBARB. Roots only $20 \mathrm{c}$ each; dozen, $\$ 2.00$.

WAGNER'S GIANT or CRIMSON WINTER. An older variety of good marketing quality. Per package, $15 \mathrm{c}$; oz., $\$ 1.50$; $1 /$ 1b., $\$ 5.00$; lb., $\$ 15.00$. Large two year old roots, $20 \mathrm{c}$ each. 


\section{Radish}

Sow almost all the year round, broadcast in beds, or in drills 12 inches apart; thin out in beds, or in drils 12 inches apart; thin out by using the largest ones which seem of suffand if grown in summer select a shady spot.

CHARTIER. A very long variety and larger in diameter and general size than Long Scarlet. Color bright rose with lighter colored tip. Per package, $5 \mathrm{c}$; oz., 20c; $1 / 4$ lb., $\$ 1.25$.

CHINESE ROSE WINTER. A bright scarlet winter variety. About 4 inches long and stump rooted. Per package, 5c; oz., 20c ; I/4 1b., 60c; lb., $\$ 1.75$.

CHINESE WHITE WINTER or CELESTIAL (California Mammoth White Winter). The well known and popular winter variety. Clear white, about 4 inches long and half stump rooted. Keeps firm and crisp until it runs to seed. Is a good cooking variety, and when cooked the flavor resembles tur. nip. Per package, $5 \mathrm{c}$; oz., 20c; $1 / 41 \mathrm{~b} ., 45 \mathrm{c}$; 1b., $\$ 1.25$.

CRIMSON GIANT FORCING. The best large solid radish; very crisp. The roots are top shaped, $13 / 4$ inches in diameter, and remain solid. Superb sort for every garden. Per package, $5 \mathrm{c}$; oz., $20 \mathrm{c}$; $1 / 4 \mathrm{lb}$., $45 \mathrm{c}$; 1b., $\$ 1.25$.

EARLY SCARLET TURNIP. A valuable variety for forcing or outdoor culture. Is a small, turnip shaped variety and in color entirely crimson. Per package, 5c; oz., $20 \mathrm{c} ; 1 / 4$ lb., $50 \mathrm{c}$; lb., $\$ 1.50$.

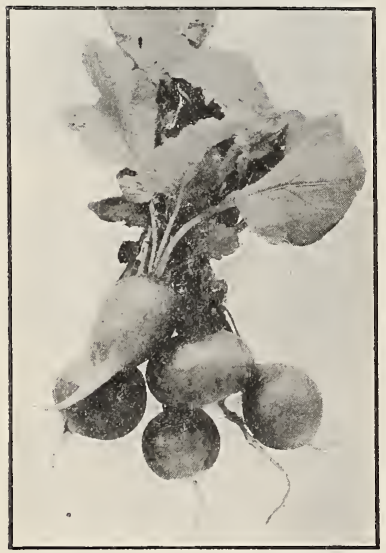

Early Scarlet Turnip Radish

EARLY SCARLET GLOBE. A popular forcing variety, owing to its very quick growth and fine, bright scarlet color. Shape a trifle oblong. Per package, $5 \mathrm{c}$; oz., $20 \mathrm{c}$; $1 / 4$ 1b., $45 \mathrm{c}$; 1b., $\$ 1.25$.

FRENCH BREAKFAST. Color bright rose, with bottom of root and the tail pure white, about 2 inches long. A very attractive variety. Per package, $5 \mathrm{c}$; oz., $20 \mathrm{c}$; $1 / 4 \mathrm{Ib}$. $45 \mathrm{c}$; 1b., \$1.25.

ICICLE. A handsome white variety, about 5 inches long, with sloping top and pointed root. Quick growing, brittle and mild in flavor. Icicle is early and very desirable for a home garden. Per package, $5 \mathrm{c}$; oz. $20 \mathrm{c}$; $1 / 4$ lb., $45 \mathrm{c}$; 1b., $\$ 1.25$.

LONG BLACK SPANISH. A winter variety with almost black skin and white flesh. Roots about 6 inches long. Per package, $5 \mathrm{c} ;$ oz., $20 \mathrm{c}$; $1 / 4$ lb., $50 \mathrm{c}$; lb., $\$ 1.50$.
HALF LONG. The variety most largely used by gardeners in California. It is about 3 inches long, with tapering root and sloping top. Color carmine. Quick grow. ing, hardy. Remains solid longer than most other varieties, Per package, $5 \mathrm{c}$; oz., $20 \mathrm{c}$; $1 / 4$ lb., $45 \mathrm{c}$; Ib., $\$ 1.25$.

LONG SCARLET. The best known and most popular long variety. Color bright carmine and flesh brittle and firm. About 6 inches long, the top growing out of the ground about 1 inch. Per package, $5 \mathrm{c}$; oz., $20 \mathrm{c}$; $1 / 4$ lb., $45 \mathrm{c}$; lb., $\$ 1.25$.

LONG WHITE JAPANESE. A new winter variety, growing frequently 2 feet long and about 3 inches in diameter. Skin white, flesh solid and tender, very pungent. Seed imported from Japan. Worthy of a trial. Per package, 5c; oz., 30c; $1 / 4$ lb., $\$ 1$; Per pack. $\$ 3$.

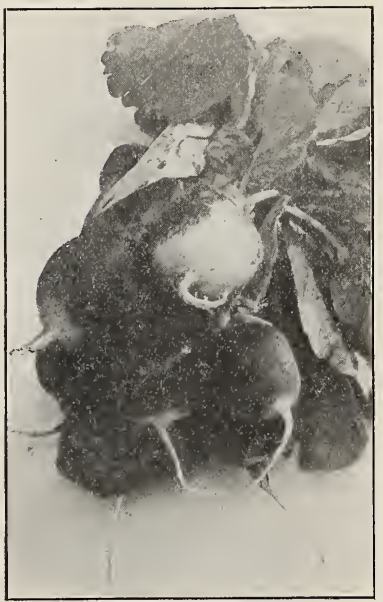

Crimson Giant Radish

SCARLET TURNIP WHITE TIPPED or ROSY GEM. One of the most popular and attractive short varieties. It is globe shaped, bright rose carmine with bottom and tip clear white. Stems and leaves and tip vear valuable for forcing as well as for the garden and market. Per package, $5 \mathrm{c}$; oz., $20 \mathrm{c}$; $1 / 4$ 1b., $45 \mathrm{c} ; 1 \mathrm{~b} ., \$ 1.25$.

WHITE VIENNA or LADY FINGER. Per package, $5 \mathrm{c}$; oz., $20 \mathrm{c}$; $1 / 4$ 1b., $60 \mathrm{c}$; 1b., $\$ 1.75$.

\section{Spinach}

An easily grown plant, the seed of which may be planted in the fall to secure better may be planted in the fall to secure better spinach early in the spring or even throughout the winter. The better and richer the soil, the larger and more tender the leaves will be. As a field crop for the market garden use 8 pounds of seed per acre; for the home garden use one ounce for 100 feet of

BLOOMSDALE SAVOY. The variety most generally used in the East and especially throughout the South for shipping. Leaves large, round and thick, very much savoyed and rich deep green. One of the earliest varieties. Seed round. Per package, $5 \mathrm{c}$; varieties. $4 \mathrm{lb}, 25 \mathrm{c}$; lb., $75 \mathrm{c}$.

LONG STANDING. A deep green variety with rather elongated smooth leaves. Seed round. Stands a long time without running to seed, even in hot weather. Per package, $5 \mathrm{c}$; $1 / 4$ lb., $30 \mathrm{c}$; lb., $85 \mathrm{c}$.
NEW ZEALAND. A plant with thick, fleshy texture and soft crystalline leaves. Is not like the ordinary spinach in appearance, and will stand heat well. Per package, $5 c$; $1 / 4$ lb., $75 \mathrm{c} ; 1 \mathrm{~b} ., \$ 2.25$.

PRICKLY. The variety commonly used for market in California. Is very hardy and easily grown; bears large, smooth leaves, which are shaped like an arrow point. A fine winter and spring variety. Per package, $5 \mathrm{c} ; \mathrm{I} / 4 \mathrm{lb}$., $25 \mathrm{c}$; 1b., $75 \mathrm{c}$.

ROUND, THICK LEAVED. A large leaved, bright green variety. Leaves rather smooth and rounded at the top. A good variety for late spring and summer. Seed round. Per package, $5 \mathrm{c}$; 1/4 1b., $25 \mathrm{c}$; 1b., $75 \mathrm{c}$.

\section{Salsify or Vegetable Oyster}

Sow in deep, rich loam, in drills twelve inches apart; thin out to three or four inches. Its culture is the same as that recommended for carrots.

MAMMOTH SANDWICH ISLAND. Produces a large crop of long, smooth roots. Per package, $5 \mathrm{c}$; oz., $25 \mathrm{c}$; 1b., $\$ 2.50$.

\section{Squash}

Prepare the soil and sow the same as for cucumbers and melons. Sow the bush varieties in hills four feet apart; the running varieties eight feet apart.

EARLY WHITE BUSH SCALLOPED. The best early variety for our climate; very productive and excellent for the market. productive and excellent for the market. and flesh of excellent flavor. Per package, $5 \mathrm{c} ; 0 z ., 10 \mathrm{c} ; 1 \mathrm{~b} ., \$ 1.25$.

WINTER CROOK-NECK. A fine variety for pies. Per package, $5 \mathrm{c}$; oz., $10 \mathrm{c}$; 1b., $\$ 1.00$.

YELLOW CROOK-NECK, SUMMER. Skin yellow, thin, hard and warty. A very early, prolific variety with curved neck. Per package, $5 \mathrm{c}$; oz., $15 \mathrm{c}$; lb., $\$ 1.50$.

BOSTON MARROW. A late variety, mottled; deep orange and cream colored. Very productive and a good keeper. Per package, $5 \mathrm{c}$; oz., $10 \mathrm{c}$; Ib., $80 \mathrm{c}$.

HUBBARD. One of the most popular old varieties; bluish green on the outside and very hard; very dry flesh, rich and sweet. Per package, $5 \mathrm{c}$; oz., $20 \mathrm{c}$; lb., $\$ 2$.

GOLDEN HUBBARD. Skin orange red in color; flesh deep orange and of excellent flavor. A new variety, likely to become very popular. Per package, $5 \mathrm{c}$; oz., 20c; lb., $\$ 2$.

SIBLEY or PIKE'S PEAK. A distinct variety. Considered by many superior to the Hubbard. Per package, 5c; oz., 20c ; Ib., $\$ 2$.

FORDHOOK. Fruit oblong in form and about 10 inches long; slightly ridged, yellowish skin. The flesh is very thick and light straw coior, and the vines are very strong and vigorous; often used for covering fences; a very desirable variety of squash. Per package, $5 \mathrm{c}$; oz., 15c; 1b., $\$ 1.25$.

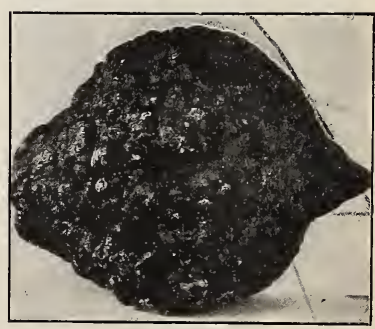

Hubbard Squash 


\section{Swiss Chard}

\section{(Sea Kale Beet)}

There are a number of varieties of Swis Chard. The one we offer is known as Perpetual Spinach, grown for us by European seed growers; not the mixed sugar beet and Swiss chard, but the genuine true stock. Used exclusively for its stalk and leaves which when cooked as spinach are tender and wholesome. They can be cut for two years, which makes them valuable for poultry keep ers, as the Swiss chard will produce more food on a given space than lettuce or kale.

LARGE RIBBED WHITE. Sometimes called "Spinach Beet." Used for greens for chickens by cutting the stem and leaf, which are also very ornamental. It resembles an ornamental beet top, but has no edible root. Mamental beet top, but has no edible root. Per package, $5 \mathrm{c}$; oz., $15 \mathrm{c}$; lb., $\$ 1.80$.

GIANT LUCULLUS. This is the largest variety of Swiss Chard in cultivation; the numerous leaves are crumpled and curled, of a light green color. On account of its productiveness we recommend it for the home garden. Per package, $5 \mathrm{c}$; oz., $15 \mathrm{c}$; lb., $\$ 1.80$.

\section{Tomatoes}

Sow the early varieties about the 15 th of August in shady places. Keep the little seedlings in good, healthy condition; transplant about the middle of September, in rows five feet apart, and keep them well watered and hoed. The growing of early or winter toma toes can only be done in favorable locations, such as in Montebello, Cahuenga Valley, Eagle Rock or similar warm situations. Other varieties sown about the first of the year in frames or hotbeds, protected from late frosts plant out and cultivate the same as the earliest varieties.

The main cause of failure in growing tomatoes, especially in the small home garden, is due to the frequent sprinkling that these plants receive. There is only one way to water tomatoes. That is by irrigation. When tomatoes are sprinkled, especially when they are in bloom, the pollen of the flowers is scattered, making it impossible for the fruits to form.

When tomatoes have been grown for a number of years in the same soil, it is advisable to secure a commercial fertilizer which contains a large percentage of potash. The $a b$ sence of potash in the soil is one of the causes of the fruit dropping off.

Tomatoes should not be irrigated very much after the fruit begins to form. The fruit is inuch sweeter and firmer if water is used sparingly.

ACME. A popular variety; dark purplish red in color. Per package, 5̌c; oz., 40c : lb., $\$ 4$.

SAN JOSE CANNER. This splendid tomato was introduced early in 1914. The true stock is unsurpassed for heavy yield, solidity, good canning, marketing, and shipping qualities. The premier tomato throughout most of California. Some parties have named a big round tomato San Jose Canner which is an entirely different thing. Per package, $15 \mathrm{c}$; 0.z., $90 \mathrm{c} ; 1 / 4$ lb., $\$ 3.50 ; 1 \mathrm{~b} ., \$ 10$.

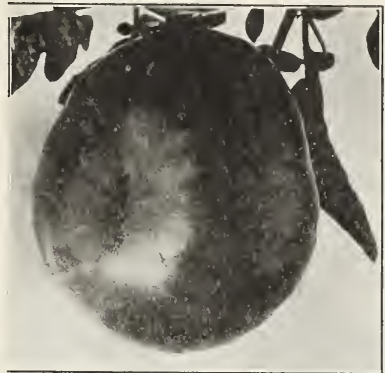

Spark's Earliana

GOLDEN QUEEN TOMATO. A real good yellow sort; first class quality for table use. The golden slices make a beautiful contrast with the red sorts. Per package, $10 \mathrm{c}$; lb., $\$ 5$.

GROUND CHERRY. Entirely different from other tomatoes, as the fruit is very small and round and is enclosed in a husk; is excellent for preserves and is used almost entirely for this purpose. Per package, 10c ; lb., $\$ 5$.

LIVINGSTON'S FAVORITE. One of the best for all around use; vigorous and continues to bear all season, Per package, $5 \mathrm{c}$; tinues to bear all
oz., $40 \mathrm{c}$; lb., $\$ 4$.

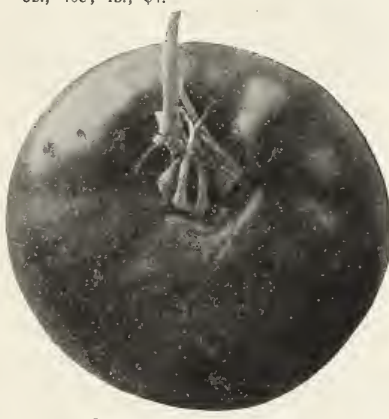

San Jose Canner Tomato

LIVINGSTON'S NEW CORELESS. This tomato is almost round in shape and is bright red in color. It is immensely productive, bearing clusters of four to seven fruits six to eight inches apart along the stem; fruit all of marketable size, weighing 12 to 15 ounces. Free from green core; ripens all over at once. A splendid slicing fruit. Per package, $5 \mathrm{c}$; oz., $60 \mathrm{c}$; lb., $\$ 4.00$.
MATCHLESS. A fine one for canning; large and smooth. Per package, $5 \mathrm{c} ; \mathrm{oz}$. $40 \mathrm{c} ; \mathrm{lb} ., \$ 4$.

NEW JUNE PINK TOMATO. One of Johuson \& Stoke's great tomato novelties. It can be called Pink Earliana, as it differs from that variety only in its color, which is a bright pink instead of red. The plant is very compact and branches freely. The fruit hangs in clusters; one of the most desirable pink tomatoes on account of its earliness and heavy yielding, also its excel lent shipping qualities. It resists the blight lent shipping qualities. It resists the blight
better than any other variety. Per package, $5 \mathrm{c} ; 0 \mathrm{z} ., 40 \mathrm{c}$; lb., $\$ 4$.

PONDEROSA, or BEEFSTEAK. One of the largest in cultivation. Smooth and solid. Per package, $5 \mathrm{c}$; oz., $60 \mathrm{c}$; lb., $\$ 6$.

ROYAL RED. Large tomato of a brilliant red color; vigorous grower. Per package, $5 \mathrm{c} ;$ oz., $40 \mathrm{c}$; 1b., $\$ 4$.

CHALK'S EARLY JEWEL. An extra early sort; smooth, round and bright scarlet very productive. It is fine in color, form and solidity and other essential qualities. and solidity and other essential qualities.
Fruit grows in clusters, containing very Fruit grows in clusters, containing very
few seeds. Per package, 5c; oz., $40 \mathrm{c} ; 1 \mathrm{~b} ., \$ 4$.

SPARK'S EARLIANA. The best extra early sort, smooth, round and bright scarlet; very productive. It has no equal in formation and quality; has proved very remunerative to grower's market. Grows in clusters from five to eight, fruiting clear to the stem, and does not crack. Per package, $5 \mathrm{c}$; oz., $40 \mathrm{c}$; lb., $\$ 4$.

STONE. One of the most reliable tomatoes; of large size and of good quality and form; apple shaped; deep red in color: bearing clumps of red fruit, which is extra bearing clumps of red fruit, which is extra
heavy. Per package, 5c; oz., $40 \mathrm{c} ; 1 \mathrm{~b} ., \$ 4$.

TREE TOMATO Or DWARF CHAMPION. So called from growing in treelike form We especially recommend this variety for the family garden, as it is easier grown and will produce more tomatoes on a given space than any other variety because it does not vine, but grows in a compact form, resembling the dwarf apple trees, fruits being the same size as an ordinary apple. Per package, 5c; oz., $40 \mathrm{c}$; 1b., $\$ 4$.

When ordering Asparagus Roots, Cabbage and Vegetable Plants of all descriptions by $\mathrm{P}$ arcel Post, kindly add $5 \mathrm{c}$ postage for each dozen ordered, if ordered by the dozen, or $20 \mathrm{c}$ for each hundred plants the dozen,
ordered.

\section{Tomato Plants}

We can furnish tomato plants almost all the year round, beginning in February with Tree Tomatoes, Earliana, Stone, Atlantic Prize and other early sorts, and later in the season Beefsteak tomatoes and all other leading varieties. In August we have Atlantic Prize, Earliana and Stone for winter planting. Price, $20 \mathrm{c}$ a dozen, of $\$ 1.50$ per hundred.

Customers that are located more than sev enty-five miles from Los Angeles we advise to raise their own tomato plants. It is almost impossible, even with the utmost of care, to pack these tender plants so that they will arrive at such distance in good shape.

Chayote (Sechium Edule)

A South American variety of Squash making a trmendous vine that is fine for corering fences, buildings and trellises. The Chayote is a tremendous grower and produces a very large crop of fruit during the season. The fruit averages about five inches in length and is about two and a half inches thick and weighs about one pound. This fruit can be prepared in a number of ways. It can be fried as Eggplant, stewed as Squash or used as a salad. It is greatly relished when the roots are prepared as Sweet Potatoes.

The fruit contains but one seed, and generally the entire fruit, seed and all, is planted. We supply these fruits from November to January 1 st at the rate of $10 \mathrm{c}$ each. By mail, $15 \mathrm{c}$ each. From January 1 st through the Spring we furnish the plants of Chayote in pots at $25 \mathrm{c}$. 


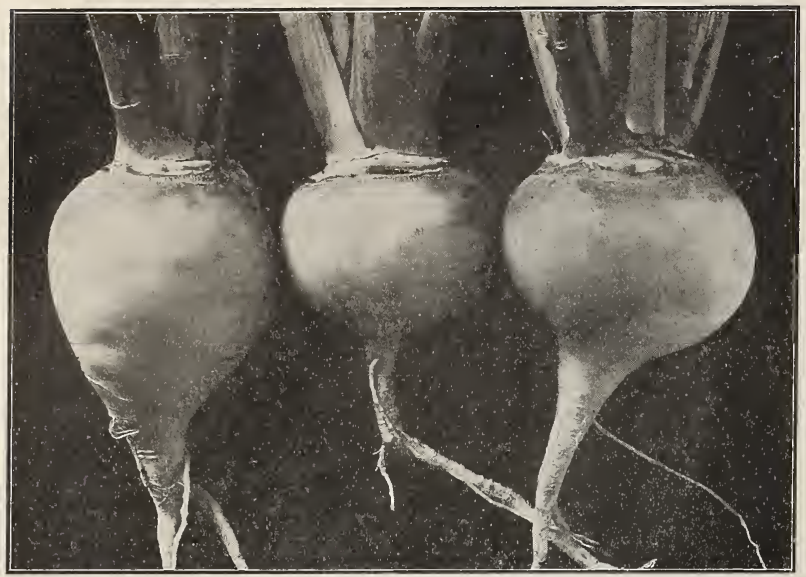

Purple Top Turnip

\section{Turnips}

Turnips grown quickly, so that they are tender, make a delicious vegetable. The home gardener can give them easily that extra care needed to bring them to perfection. The requirements are for a rapid, uninterrupted growth, and for moist, well worked soil. In Alaska turnips reach perfection, and all over Alaska turnips reach perfection, and all over our coast they are excellent. Sow in early
spring and again in August. This latter gives roots for winter. Put the rows 12 to 18 inches apart, and thin to 5 to 8 inches. Do not transplant except when very young and that should not be necessary. One ounce of seed sows 250 feet of row.

AMBER or YELLOW GLOBE. Skin a clear yellow; is of large size and fine flavor. Per package, 5c; oz., 20c; $1 / 4$ lb., 35c; lb., $\$ 1$.

EARLY SNOWBALL. A medium, pure white, globe shaped variety. Very solid and of finest quality for table. Per package, $5 \mathrm{c} ;$ oz., $20 \mathrm{c}$; $1 / 4$ 1b., $45 \mathrm{c}$; 1b., $\$ 1.25$.

EARLY WHITE FLAT DUTCH. A medium sized flat variety; clear white, early and of fine flavor. A fine table variety. Per package, $5 \mathrm{c}$; oz., $20 \mathrm{c}$; $1 / 4$ lb., $35 \mathrm{c} ; 1 \mathrm{~b} ., \$ 1$.

EXTRA EARLY PURPLE TOP MILAN. A very early variety, medium sized, very flat, and white with purple top. Per pack-

LONG WHITE or COWHORN. A long, pure white variety, resembling a white carrot. The flesh is tender and sweet and it is quite popular as a market variety on this account. Per package, $5 \mathrm{c}$; oz., $20 \mathrm{c}$; $1 / 41 \mathrm{~b}$., $50 \mathrm{c} ; 1 \mathrm{~b} ., \$ 1.50$.

ORANGE JELLY or GOLDEN BALL. A globe shaped, yellow variety with firm and crisp yellow flesh. A very fine table variety. $\$ 1.25$.

POMERANIAN WHITE GLOBE. Large white variety, used largely for stock feeding. Is globe shaped, large leaves, hardy. Per package, $5 \mathrm{c}$; oz:, $20 \mathrm{c}$; $\mathrm{x} / 4$ 1b., $35 \mathrm{c}$; lb., $\$ 1$.

PURPLE TOP WHITE GLOBE. Flesh white, firm and tender. Per package, 5c; oz., 20c; $1 / 4$ lb., 35c; lb., $\$ 1$.

PURPLE TOP ABERDEEN. A medium sized variety, generally used for stock feeding. Is yellow, with purple top. Flesh light yellow. A winter variety, seed of which can be sown in summer. Per pack age, $5 \mathrm{c}$; oz., 20c; $1 / 4$ lb., $35 \mathrm{c} ; 1 \mathrm{~b} ., \$ 1$.
PURPLE TOP FLAT DUTCH. One of the most largely used varieties. Flat with purple top. Per package, $5 \mathrm{c}$; oz., $20 \mathrm{c} ; \mathrm{z} / 4 \mathrm{lb}$., $35 \mathrm{c} ; 1 \mathrm{~b} ., \$ 1$.

SEVEN TOP. For Greens. Cultivated for its leaves. Cooked same as spinach and mustard. The root is small and not used. Per package, $5 \mathrm{c}$; oz., $20 \mathrm{c} ; \mathrm{x} / 4 \mathrm{lb}, 45 \mathrm{c}$; $1 \mathrm{~b}$., Per p
$\$ 1.25$.

WHITE EGG. A small, early, ablong variety. Per package, 5c; oz., 20c; 1/4 lb., $45 \mathrm{c} ; 1 \mathrm{~b}$., $\$ 1.25$.

RUTABEGA or SWEDE. These are grown usually for stock feeding and make an ex cellent and valuable crop. Treatment same as for winter turnips, but require a longer season to grow. The seed should be planted early in July in rows at least $21 / 2$ feet apart and the plants thinned to 8 to 1 inches apart. Per package, $5 \mathrm{c} ; 1 \mathrm{~b} ., \$ 1.25$.

AMERICAN PURPLE TOP or LONG ISLAND. One of the best and most popular varieties, with yellow flesh. It is yel low below ground, with purple top above, and the leaves are small. A good stock feeding or table variety. Per package, 5c; oz., 20c; $1 / 41 \mathrm{~b} ., 35 \mathrm{c}$; 1b., $\$ 1$.

YELLOW PURPLE TOP SWEDE. Pe package, $5 \mathrm{c}$; oz., 20c; $1 / 4$ lb., $35 \mathrm{c}$; 1b., $\$ 1$

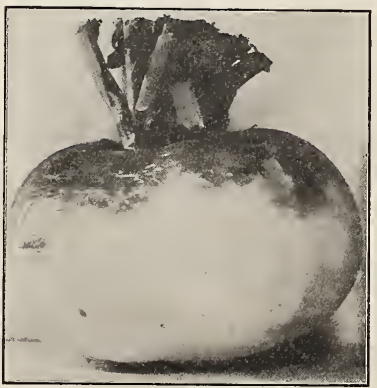

Purple Top Strap Leaf

\section{Seed Potatoes}

All of our stock is from Certified Fieids which means that all hills are true to their type and variety. They have all been carefully rogued and not only ai the mixtures taken out, but all the weak hills too. This insures uniform stock.

Where soil is rich and deep, potatoes may be planted as close as 12 or 14 inches in the row, with rows 24 inches apart, but of course where they are planted in larger acreages, cultivation will have to be done by horse labor, and the rows should be about 36 inches apart.

In coast regions of California, planting may begin in early winter months, but in most districts February to March is best. Second crop plantings are usually begun in July. Early potatoes require about 75 to 90 days for a matured crop, while late varieties will take from 110 to 130 days, according to variety and district. Prices given are subject to market fluctuations.

All potatoes are prices F. O. B. Los Angeles, but where small quantities are required by mail, add extra postage at the rate according to the zone you live in from Los Angeles. Zone rates will be found on inside of front cover. Prices subject to change without notice.

BRITISH QUEEN. This is the best potato for most sections of California. Our strain came from England and has had constant hill selection ever since, giving us a very prolific and disease resisting potato, which stands alone on its merits in this state. It is oval in shape and has cream skin with white flesh. Very shallow eyes. Can be planted as an early potato and dug while tops are green, although in many sections it is planted as a main crop variety. 5 lbs., $35 \mathrm{c}$; 10 lbs., $60 \mathrm{c}$; 25 lbs., $\$ 1.15$; 50 lbs., $\$ 2.15 ; 100$ lbs., $\$ 4$.

AMERICAN WONDER. This stock has been hill selected for years until it really does not resemble the ordinary American Wonder potato. They come in good uniform type and are excellent for light soils and can be planted very close together. Matures in about 100 days. Can highly Matures in about 100 days, Can highly recommend this variety. 5 lbs., $35 \mathrm{c}$; 10
lbs., $60 \mathrm{c} ; 25$ lbs., $\$ 1.15 ; 50$ lbs., $\$ 2.15$; 100 lbs., \$4.

WHITE ROSE. This is the long, white skinned variety used so much in the south. Matures very early. A wonderful good cropper and cooker. Our strain is of the cropper and cooker. Our strain is of the
very best picked stock. $5 \mathrm{lbs}, 35 \mathrm{c} ; 10 \mathrm{lbs}$, $60 \mathrm{c} ; 25$ lbs., $\$ 1.15$; 50 lbs., $\$ 2.15 ; 100$ lbs., \$4.

WHITE BURBANK LOW TOP. Certified stock of this well known, oblong, smooth skinned potato, a main crop variety. Very heavy yielder. 5 lbs., $35 \mathrm{c}$; $10 \mathrm{lbs}, 60 \mathrm{c}$; 25 lbs., $\$ 1.15 ; 50$ lbs., $\$ 2.15$; 100 lbs., $\$ 4$.

\section{Water Cress}

FINE CURLED (Pepper Grass). For lending piquancy to salads this variety is un surpassed. Per package, $10 \mathrm{c}$; oz., $20 \mathrm{c}$; $1 / 4$ $50 \mathrm{c} ; 1 \mathrm{~b} ., \$ 1.50$

\section{Aromatic, Medicinal and Pot Herbs}

ANISE. Per package, $10 c$; oz., $35 c$

BALM. Per package, $10 \mathrm{c}$; oz., 60

BASIL, SWEET. Per package, $10 \mathrm{c}$; oz., 50c BORAGE. Per package, $10 \mathrm{c}$; oz., $50 \mathrm{c}$. CARAWAY. Per package, $10 \mathrm{c}$; oz., $25 \mathrm{c}$. CATNIP. Per package, 10c; oz., \$1.0.

DILL. Per package, 10c; oz, , 25c.

FENNEL, SWEET. Per package, $10 \mathrm{c}$; oz. HOREHOUND. Per package, $10 \mathrm{c}$; oz., $75 \mathrm{c}$. LAVENDER. Per package, 10c ; oz., 70c. ROSEMARY. Per package, $10 \mathrm{c} ;$ oz., $\$ 1$. SAGE. Per package, $10 \mathrm{c}$; oz., $75 \mathrm{c}$.

SUMMER SAVORY. Per package, $10 \mathrm{c}$; oz. SWEET MARJORAM. Per package, $10 \mathrm{c}$ WINTER SAVORY. Per package, 10c; oz. TANSY. Per package, $10 \mathrm{c}$; oz., 85c.

TARRAGON, RUSSIAN. The true Tarragon does not seed, but what is offered is Russian Tarragon and flavorless. Per package, 15c. TRUE TARRAGON. In plants only. $50 \mathrm{c}$ TRUE TARRAGON. In plants only.
THYME, Per package, 10c; oz., $\$ 1.25$.

WORMWOOD. Per package, 10c; oz., $65 \mathrm{c}$. 


\section{Desirable Forage and Fodder Plants}

The prices given below are market prices on Jantary 1st. These seeds and plants are stbject to market fluctuations.

\section{Napier Grass}

Napier Grass, sometines called African Elephant Grass, or Australian Giant Grass, is the fastest growing perennial grass we have ever seen, especially after it has been planted one year and the roots are thoroughly established. It belongs to the Millet family, but produces It belongs to the like cane. It grows readily from the joints of the matured stalk and mul. from the joints of the matured stalk and mul-
tiplies wonderfully in stooling out, often being from 50 to 100 stalks in one cluster. One joint produced over 1500 joints to plant the first year.

This perennial Napier Grass far surpasses the heavicst yielding crops known in the Southern states, according to our experiments, which verify reports coming from Australia. Sudan Grass and the sorghums so much advocated of late for forage crops as well as alfalfa, must all take lower rank in quantity of feed produced if the present estimates are even partially borne out in general culture.

Joints of the matured stalk of Napier Grass at $\$ 5$ per hundred or $\$ 1$ per dozen in small quantities.

\section{Fodder Plants}

ALFALFA. The most valuable fodder plant ever introduced in California. We make a specialty of high grade Alfalfa seed, and we cheerfully furnish samples to prospective offering for sale; we like our customers to offering for sale; we like our customers to
do the same with the sample they receive.

CHILIAN EXTRA CHOICE RECLEANED.

The best acclimated sort, and recommended for all round growing. Yields very heavily. We are always prepared to quote the low cst market prices for seed. Lb., $35 \mathrm{c} ; 10$ lbs., $\$ 3$.

PERUVIAN ALFALFA. Smooth strain. Grows very quickly and yields heavily. Lb., 40c; 10 lbs., $\$ 3.50$.

HAIRY PERUVIAN. This is a wonderful alfalfa. It starts to grow while the weather is yet cool and makes one or more additional cuttings a season. This gives a much larger tonnage, sometimes 20 per cent more. The leaves and stems are covered with fine downy hairs. Lb., 35c; $10 \mathrm{lbs}$., $\$ 3.50$.

CANADA FIELD PEAS. Excellent for cover crop or for forage for cattle. Makes good growth even if planted late. Sow 70 to 80 pounds per acre. Inoculated soils are essential. Lb., $20 \mathrm{c}$.

GERMAN MILLET (Panicum germanicum). Will grow on any good land and yields heavily when artificially watered; yields from 40 to 60 bushels of seed per acre, which is excellent food for stock or poultry A good, green fodder plant. Sow 30 pounds per acre. Lb., 20c. Write for prices.

HOG MILLET. The seed is large for a Millet and makes a rich food. Good for hogs or chickens. The seed ripens while the stem is yet green, so that if cut prompt. ly you can get a crop of seed and also one of fodder or ensilage. Lb., 20c.

RAPE, DWARF ESSEX. A biennial crop, used principally for sheep and hog pasture, of which it yields an abundance of the best quality. Is usually sown broadcast, using 4 to 5 pounds per acre. Lb., $25 \mathrm{c}$; 10 lbs., $\$ 1.80$.

SOJA BEAN. Valuable as a forage crop or green manure. Also as a green fodder and silo plant. Sow 30 pounds per acre after danger from frost is past. Lb., $20 \mathrm{c}$.

SUNFLOWER, LARGE RUSSIAN. This bears large heads, frequently 12 to 20 inches in diameter and sometimes yielding 1000 pounds of seed per acre. The seed is used for feeding chickens and parrots. Sow in the open field as soon as danger from frost is over, using 3 pounds of seed per acre, sowing in rows 5 feet a part and thinning to 1 foot. Lb., $15 \mathrm{c}$.

SWEET, OR BOKHARA CLOVER (Melilotus alba). Lb., $30 \mathrm{c} ; 10 \mathrm{lbs}$., $\$ 2.50$.
HAIRY, OR SAND VETCH (Vicia villosa). Roots decply and makes a good winter growth. Cut as soon as the blossoms ap-
pcar. Adapted for sandy soil and cold weather. Lb., $35 \mathrm{c}$

WINTER VETCH (Vicia desycarpa). For sandy soils this is a splendid sort. It stands cold well and makes a large winter growth because it starts early. There is no vetch per acre. Lb., 30c; 10 lbs., \$2.50.

VETCHES, SPRING, OR TARES (Vicia sativa). Also called Common Vetch, Oreresembling pea vines and valuable for forage or green manure. As a hay crop, it is usually sown with oats or wheat to hold them up. Sow 60 pounds per acre with grain, or 80 to 100 pounds if sown alone. Is hardy and makes a fine winter growth. Largely planted in the orange groves of the south for green manure, and plowed under in the spring. Lb., 20c; 10 lbs., $\$ 1.50$.

VELVET BEAN. Grows taller and larger than any other soil plant, being sometimes 30 feet in length. Sow same as cowpeas, in rows 5 feet apart and in hills 4 feet apart in the row. Lb., $25 \mathrm{c}$.

\section{Sorghum for Forage and Grain}

Deep plowing and thorough harrowing so pounds of white milo should be ample per pounds ; three to four pounds of Feterita. Plantacre; three to four pounds of Feterita. Plantwarmed up, which would generally be about the last of April. If a corn planter is used, the seed should be dropped about 18 inches inches apart. All varieties are non-saccharine except Honey and Early Amber.

VARIETY TO PLANT. Some Sorghums require an extra amount of heat to mature grain; these are Kaffir, Shallu and Honey. Milo, either Red or White, and Feterita are well adapted for the valley around Sacramento. Under irrigation these are exceptionally heavy yielding. If planting late or if moisture is short, plant Egyptian little moisture

BROOM CORN (Improved Dwarf Evergreen). Extensively used for making brooms on account of its green color and fine long, straight brush. It grows about 7 feet high. Sow 10 pounds per acre. Lb., 20c.

DWARF WHITE MILO. Succeeds under a wider range of conditions than others of its class. Yields very heavily in grain and also heavily in fodder or silage. Our seed is specially grown and selected for heavy yield. Lb., $15 \mathrm{c}$.

EGYPTIAN OR JERUSALEM CORN. It is considered a good grain for dry sections and seasons. It produces several smal heads on side shoots, often as many as eight heads on a stalk. The seed makes excellent chicken feed. Plant 8 pounds per acre. Lb., $15 \mathrm{c}$.

FETERITA. Birds do not eat this grain to the same extent that they do others, and this is a great advantage in some localities. Feterita yields heavily on grain. Plant in May. Lb., $15 \mathrm{c}$.

HONEY SORGHUM (Saccharine). For Forage and Silage. Grows 8 to 12 feet high and yields up to 27 tons per acre without irrigation, which is a third more than its nearest competitor. Matures late (150 days). Syrup can be made from this sort. Sow 3 to 4 pounds per acre in rows 3 to 6 feet apart. Lb., 20c.

KAFFIR CORN, WHITE. Grows from 6 to 10 feet high and thrives in hot, dry climates. Makes good fodder for cattle and the seed in rows 3 feet apart, using 3 to 5 pounds per acre. Lb., 20c.

RED MILO. Makes many side shoots and is a heavy yielder. Lb., $15 \mathrm{c}$.
SHALLU OR EGYPTIAN WHEAT. A tall growing Sorghum which has many stalks from onc root. Sow in rows for grain,
using 3 to 5 pounds per acre, or broadcast using 30 pounds for fodder. Lb., 20 c.

SUGAR CANE SORGHUM, EARLY AM$B E R$, A good fodder if cut when the heads form, or good silage if cut whell full grown. fore best for late sowing. Syrup can be made from this variety. Sow 5 pounds o seed per acre in drills or 25 pounds broadcast. Lb., $15 \mathrm{c}$.

\section{Grasses for Lawns and Pastures}

Our grass seeds are purchased by us from the best possible source for reliability, and all stock is tested before being offered. PUTTING GREEN MIXTURE. This makes a very springy, fine turf, which will mat
and stand lots of hard wear. Lb., $75 \mathrm{c}$; 10 lbs., $\$ 7$.

PACIFIC RYE GRASS. A fine leaved Rye Grass, very durable and wonderful on sandy soil. Lb., 35c; 10 lbs., $\$ 3.00$.

PERENNIAL RYE GRASS. For growing quickly this variety has no superior. It is light green in color, very vigorous, grows well in winter,
$10 \mathrm{lbs}$., $\$ 3.00$.

KENTUCKY BLUE GRASS. Makes an excellent lawn of a dark green color. It forms a fine mat, and with care and water is the best lawn grass for all soils except sandy ones. Lb., 60c.

WHITE CLOVER. This is the little dwar growing Clover used for lawns, either alone or in grass mixtures. Lb., \$1; 10 lbs., \$9.

BERMUDA GRASS (Cynodon Dactylon) Is a dwarf perennial plant and spreads by means of its long and many jointed root stalks, and for this reason is hard to eradi cate once it has secured a foothold. Thrives during the hottest part of the year, and Makes a durable lawn and is also used to hold embankments. This grass is much hold embankments. This grass is much seed is very slow to germinate and requires heat and moisture. Sow 10 pounds per acre. Lb., 50c. Write us for prices on larger quantities.

CHEWING'S FESQUE (Festuca duriuscula). A variety of hard fescue, and used by most of the golf clubs extensively in their mixtures. Forms a compact mat, stems are hard. The grass succeeds well even under poor conditions. A good pasture grass fo dry lands. Sow 30 pounds per acre. Lb.,
$\$ 1$. Write us for prices on larger quantities.

ITALIAN RYE GRASS (Lolium italicum) Thrives in almost any soil and yields early and abundant crops. Sown in the fall, will produce an excellent hay crop the following season, but lasts only one year. Much sown in Humboldt County for pasture and hay. pounds per acre. Lb., 25c. Write us for prices on larger quantities.

MEADOW FESCUE, OR ENGLISH BLUE GRASS (Festuca pratensis). A valuable grass for permanent pasture and for rather damp meadows for cutting. Makes a quick second growth, but does not do so well on dry soils. Sow 30 pounds per acre. Lb., $50 \mathrm{c}$.

SUDAN GRASS. It yields from 2 to 8 tons of hay per acre, depending upon whether irrigated or not. Two cuttings are assured and in places four have been taken. The hay is of superior quality and relished by all stock. Cut with a mower just after is past. If drilled in rows 36 inches apart, you will require 2 to 4 pounds of seed to the acre; if seeded in rows 18 to 20 inches a part, 4 to 6 pounds of seed to the acre if broadcasted, 15 pounds. Lb., $15 \mathrm{c}$; 10 lbs, $\$ 1.25$. 


\section{Deciduous Fruits for Home and Commercial Growing}

\section{A Selected Assortment of the Better Known Varieties}

We exercise the greatest care to furnish only trees in first class condition. If they do not appear to be satisfactory to the purchaser when delivered, they must not be accepted, but immediately returned. We cannot be held responsible for any trees or plants after they have been accepted by the purchaser and have left our hands. We invite intending purchasers to visit our nursery, corner 49 th and Main Streets, and inspect our stock. We also give purchasers the privilege of selecting their own trees or plants. All our employees are practical men and have been instructed to handle all trees and plants with great care, and also to furnish purchaser with any information he may wish in regard to the planting, care, etc.

Deciduous Fruit Trees and Bushes are delivered from January 1 st to April 1st with the exception of those that are estahlished in cans, which can he delievered every month of the year, such as Figs, Currants, Gooseberries, etc., which have heen established in berries, etc.
this way.

Unless otherwise specified in our list that follows, all deciduous fruit trees or hushes are delivered by us open rooted, hut at all times we protect these roots with wet moss times we protect these roots with wet moss
or hurlap. This moss and hurlap should be or hurlap. This moss and hurlap

\section{Almonds}

I. X. L. Bearing heavy crops of soft shelled hut perfcct, large nuts. The tree is an upright grower, very sturdy and covered with large leaves. Price, $75 \mathrm{c}$ each.

NONPAREIL, from the French, "Without equal." Forming a beautiful tree; good hearer; nuts thin shelled. Price, 75c each.

\section{Apricots}

ROYAL. The leading variety in all parts of the state. Excellent for canning and dry ing; fruits medium and oval, slightly com pressed; dull yellow with red hlush on side exposed to sun. Flesh pale orange with rich, vinous flavor. Price, $75 \mathrm{c}$ each.

BLENHIEM. Fruits above the average in size; oval; orange color with deep yellow juicy and rich; flesh excellent; for table use, canning and drying. Price, $75 \mathrm{c}$ each.

MOORPARK. Finest apricot grown; very large, yellowish red; brownish red on the sunny side; marked with numerous dark specks and dots; flesh bright orange, easily separated from the stone, which is peculiarly perforated. Price, 75c each.

\section{Apples}

BALDWIN. Large and round; deep hright red over yellow ground with a few russet dots; very fine winter variety. Price, 75c each.

EARLY HARVEST. Medium size; hright color, tender and fine with a pleasant sharpness in flavor. Price, $75 \mathrm{c}$ each.

RED ASTRACHAN. Fruits large; deep crimson, shaded greenish yellow; flesh white; moderately juicy with a slight acid flavor; excellent for cooking. Price, 75c each.

RED JUNE. Deep red, medium size; excellent for tahle use; early variety. Price, $75 \mathrm{c}$ each.

RHODE ISLAND GREENING. Valuahle variety for a warm, dry climate; fruits yellow inside and out; fine grain and tender and crisp; excellent for cooking purposes. Price, $75 \mathrm{c}$ each.

WHITE WINTER PEARMAIN. Yellow thickly speckled with small brown dots; flesh yellow, tender and crisp; very successful in Southern California; a great mar ket variety. Price, $75 \mathrm{c}$ each.

YELLOW BELLFLOWER. Fruits large; yellow in color, sometimes tinted lightly with red on the sunny side; flesh firm and crisp; a good grower and very productive. Price, $75 \mathrm{c}$ each.

BANANA APPLE. Price, $75 \mathrm{c}$ each.

\section{Crab Apples}

RED SIBERIAN. Fruits ahout one inch in diameter; yellow with scarlet cheek. Trees erect and vigorous; bears ahundantly. erect and vigor

TRANSCENDENT. Fruits large; yellow skin with red on one side; immensely pro ductive. Price, $75 \mathrm{c}$ each.

\section{Cherries}

BLACK TARTARIAN. Old standard vari ety; tree very vigorous; erect and heautiful, immense bearer; fruits deep purplish hlack; flesh rich, juicy and delicious. Price, $\$ 1.00$ each.

ROYAL ANN (Napoleon Bigarreau). A magnificent cherry of the largest size; pale yellow with bright red cheek; flesh firm; juicy and sweet; tree an erect grower. Price, $\$ 1.00$ each.

\section{Figs}

KADOTA. The Southern California Smyrna Fig originated at Sawtelle, California, hy S. H. Taft. Fruits large, pear shaped, very white in color, almost transparent when ripe; tree very strong grower; branches heavy and closely jointed; upright growth leaves very large. Price, $50 \mathrm{c}$ and $75 \mathrm{c}$ each.

MISSION. Also called California Black Fig. This variety has been grown in California since the advent of the Mission Fathers. Through years of cultivation they have succeeded in producing good figs without hav ing their flowers pollinated. Price, 50c and $75 \mathrm{c}$ each.

WHITE ADRIATIC, A variety largely skin a greenish yellow; pulp brownish red. Price, $50 \mathrm{c}$ and $75 \mathrm{c}$ each.

WHITE SMYRNA. Large size; skin lemon yellow, pulp reddish amber; flavor and quality unsurpassed. The genuine commercial Smyrna. Price, $50 \mathrm{c}$ and $75 \mathrm{c}$ each.

WHITE PACIFIC. A very sweet white variety. Price, $50 \mathrm{c}$ and $75 \mathrm{c}$ each. planted for drying purposes. Fruits large

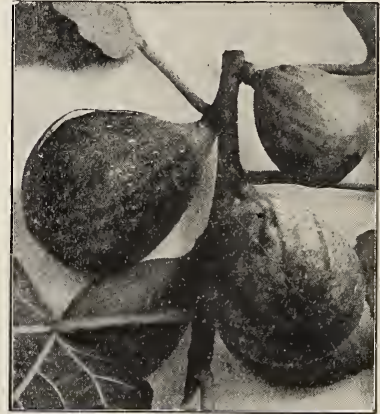

Mission Fig

\section{Mulberries}

ENGLISH. Fruits large; hlack; ahout $11 / 2$ inches long; very juicy; spreading tree, valuahle for its timber. Price, $\$ 1.00$ each.

\section{Nectarines}

BOSTON. Large and oval; hright yellow with dcep red cheek; flesh yellow with slight acid flavor. Price, $75 \mathrm{c}$ each.

STANWICK. Skin greenish white shaded with a deep violet on the sunny side; flesh white, tender and sweet. Excellent for shipping and drying. Price, $75 \mathrm{c}$.

\section{Peaches}

EARLY CRAWFORD. Ripening in the middle of July; very large fruits; skin yellow with red cheek; flesh yellow, very sweet. Price, $75 \mathrm{c}$.

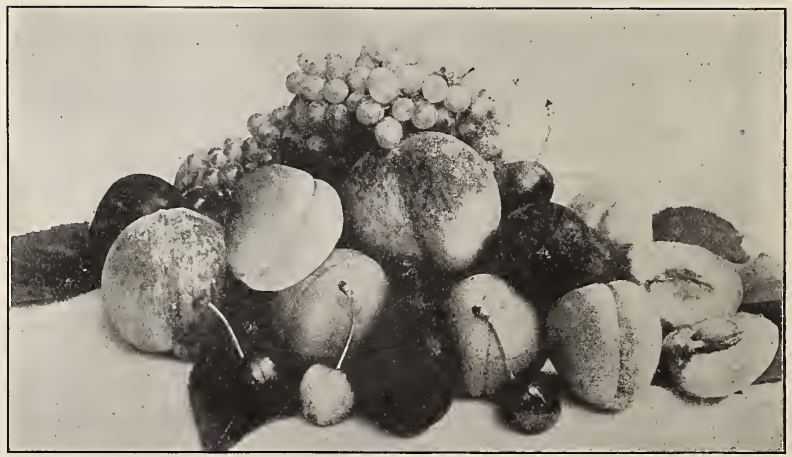

Every Home Should Have These Fruits 
LATE CRAWFORD. Ripening early in August; very large; round, yellow with dark red cheeks; flesh deep yellow; juicy and melting; flavor rich and excellent; valuable for table use, canning and drying. Price, $75 \mathrm{c}$ each.

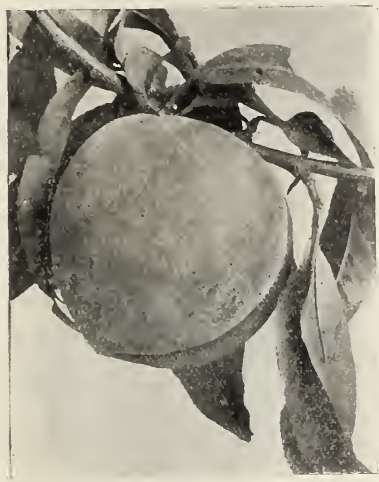

Elberta Peach

ELBERTA. Southern variety; very large, bright yellow with mottled red cheek; flesh yellow, juicy and sweet; a strong grower and heavy bearer; very choice variety for ali purposes. Price, $75 \mathrm{c}$ each.

FOSTER. Resembling the Early Crawford, but coming in earlier; flesh is firmer with less red at the stone, which is small; good for home use and commercial purposes. Price, $75 \mathrm{c}$ each.

ORANGE CLING. Fruit large and yellow, with a dark crimson cheek; flesh golden yellow, rich and sugary, with a vinous flavor; tree good bearer. Price, $75 \mathrm{c}$ each.

MUIR. One of the best freestone peaches; flesh clear yellow; very firm, rich and sweet; fine shipping variety on account of its sweetness and firmness and keeping qualities. Price, $75 \mathrm{c}$ each.

SALWAY. Popular orchard variety, fruits large; creamy yellow with brownish red cheek; flesh deep yellow, and red at the pit. Price, $75 \mathrm{c}$ each.

SAUCER PEACH. Of medium size and flat shape, slightly hollowed on one side, like a saucer, hence the name. Skin white, shaded crimson in the sun; flesh is white and sweet and the flavor delicious. Pit very small and almost round. A great favorite for home use. Price, $75 \mathrm{c}$ each.

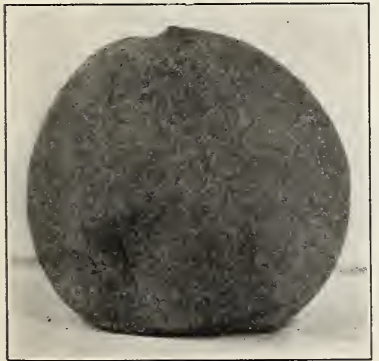

Late Crawford

\section{Loquats}

ADVANCE. Fruits large; ear shaped; skin deep lemon yellow; flesh frum and juicy and sweet. These trees are established in boxes and can be delivered and planted any time of the year. Price, $\$ 2.50$ each.

BUDDED LOQUATS. One year old buds ou two year old roots of the large fruiting variety. 8 to 10 feet, choice, $\$ 3.00$.

\section{Olive Trees}

Olive trees are always pruned as soon as taken out of the ground for transplanting, and cut back about one-third to one-half. This is absolutely necessary, as an Olive tree that is not pruned when transplanted will very seldom thrive. Wie call attention to this fact to intending purchasers, as these trees will appear much smaller upon delivery than when seen at the nursery. Standard varieties, $\$ 1.50$ each.

\section{Pears}

BARTLETT. The most popular pear in Southern California; bears large fruits very tender skin; clear lemon y ellow with soft flush on one side; flesh white and very juicy and highly flavored. Price, $75 \mathrm{c}$ each.

SECKEL. Small but very delicious variety very rich and highly variety. Skin brownequaled by any other varin cheek; flesh buttery, juicy and melting. Price, $75 \mathrm{c}$ each.

FLEMISH BEAUTY. Large, pale yellow, marbled with light russet; flesh yellowish white, not fine grained, but very juicy and melting: good bearer and very hardy. Price, $75 \mathrm{c}$ each.

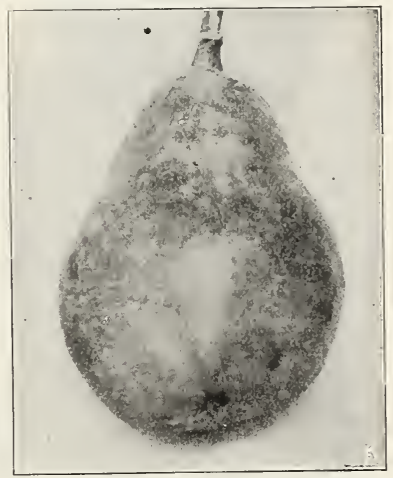

BARTLETT PEAR

\section{Persimmons}

JAPANESE. Price, $\$ 1.50$ to $\$ 2.50$ each.

\section{Plums}

BURBANK. One of Luther Burbank's productions: large and globular; fruits clear cherry red; flesh deep yellow, very sweet; finely flavored; tree very vigorous and beginning to bear when two or three years old. Price, $75 \mathrm{c}$ each.

GREEN GAGE. Fruits yellowish green; medium size; round; very rich in flavor; vigorous grower. Price, $75 \mathrm{c}$ each.

KELSEY JAPAN. Large; heart shaped; fruit green in color, changing to a rich yellow, overspreading with bright red when fully ripe; flesh yellow, very firm, clinging slightly to the stone, which is very small; makes fine looking tree; bears quantities of fruit. Price, $75 \mathrm{c}$ each.
SATSUMA. This trec is greatly in demand on account of the fine quality of its fruits, which are large and globular; skin lilac in color; flesh dark red;

flavor. Price $75 \mathrm{c}$ eacls.

WICKSON. Another of Luther Burbank's productions. Vigorous growing tree with widc leaves: grows very symmetrical fruits deep cherry red, changing to deep claret; flesh amber; very juicy; pit small good shipper. Price, $75 \mathrm{c}$ each.

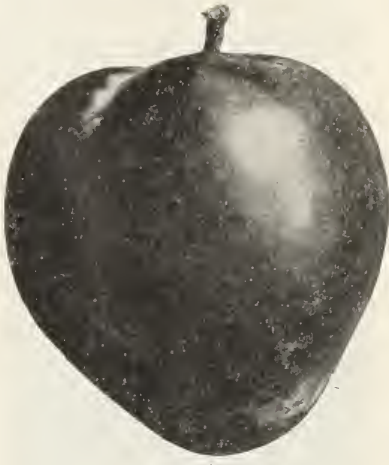

Kilsey Japan

\section{Prunes}

FRENCH, Excellent variety for drying; fruits medium size; egg shaped; violet in color, sweet, rich and sugary; very productive. Price, $75 \mathrm{c}$ each.

SUGAR. Fruits run very uniform in size; ripens fully a month earlier than the French Prune; tree very vigorous grower; immense bearer; skin very tender; dark purple when ripe; flesh yellow, ten

\section{Quinces}

ORANGE QUINCE. Large; fine golden color; excellent for preserves; very productive; our best seller. Price, $75 \mathrm{c}$ each.

\section{Walnuts}

PLACENTIA WALNUT. Soft shell nut large; shell thin and readily broken by the hand. Kernel is white, full and sweet. Best variety for Southern California. 5 to 6 feet, $\$ 2.00$ each; 6 to 8 feet, $\$ 2.25$ each; 8 feet and over, $\$ 2.50$ each.

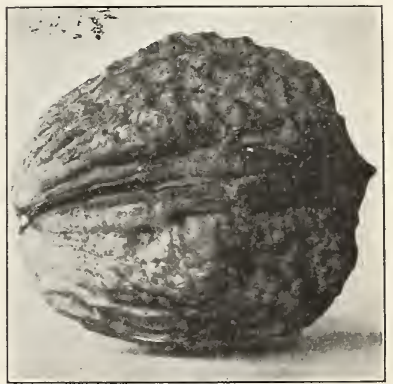

Placentia Walnut 


\section{Bush Fruits}

\section{Guavas}

GUAVAS. ..STRAWBERRY. Immense bearer, producing fruits larger than English walnuts. Skin fine deep claret color, pulp fleshy and soft, juicy and purplish red strawberry like flavor and fragrance; fine for jellies and jams; plants in one gallon cans, $25 \mathrm{c}$ to $50 \mathrm{c}$ each; in 5 gallon cans, $\$ 1.00$ to $\$ 1.50$ each.

LEMON GUAVA. A tropical variety of this beautiful fruiting shrub. Sometimes called Pear Guava. It grows to be quite a large shrub. Fruit pear shaped and yellowish delicious flavor. In 1 gal. cans, $\$ 1.00$ each.

\section{Grapes}

$25 \mathrm{c}$ each, $\$ 2.50$ per dozen.

BLACK HAMBURG. Bunches very large, heavy shouldered; berries large, round, skin thick; coal black when ripe; flesh sweet and juicy; one of the best table and marke grapes.

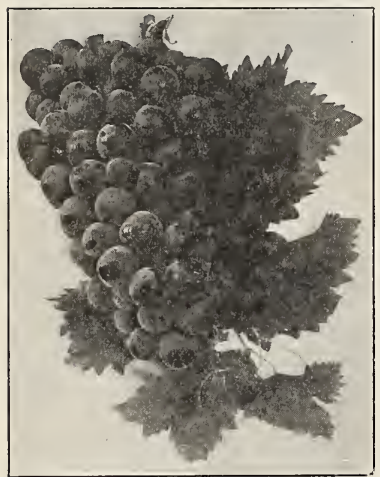

Concord

EMPEROR. Deep rose colored; bunches very large, long and loose shouldered; skin firm and thick; this makes it a good market and shipping variety.

FLAME TOKAY. Berries pale red, coming in very large bunches moderately compact flesh firm and sweet.

MALAGA. Strong growing variety; planted extensively in the Imperial Valley; very early, vines very strong and producing early, vines very strong and producing
large bunches of yellowish green berries; skin thick and fleshy.

ROSE OF PERU. Strong growing vine; well adapted for making arbors. A very fine quality grape; good bearer.

SULTANA. Bunches long and very com pact; berries small amber colored, seedless immense bearer; grows in sandy soil producing large crops.

MUSCAT. One of the most popular vari eties. Excellent for making arbors or planting in field. Good market variety.

MISSION. This is the old and well known grape; first known in California; large bunches, berries medium size, round, purple black; sweet and delicious.

THOMPSON'S SEEDLESS. Enormous bearer; rapid grower; bunches large, greenish yellow, seedless; skin thin; much larger than the Sultana.

CONCORD. Growing large bunches of black berries; flesh moderately juicy; very sweet; vigorous; adapted for trailing or covering arbors.
PIERCE, OR CALIFORNIA CONCORD. A giant leaved and very prolific variety. A giant leaved and very prolific variety. The berries, like the leaves, are of extraordinary size, and when ripe the fruit is exceedingly sweet and strongly aromatic berries a bluish black when fully matured;

\section{BERRY FRUITS}

LOGANBERRIES. A hybrid between Rasp berry and Blackberry, producing fruits avera ring an inch long, of a dark red color and bearing in immense clusters. Canes are very large without thorns, but have fine soft spines. Price, 20c each; $\$ 2.00$ pe dozen.

EVERGREEN BLACKBERRIES. Berries large, black, sweet, rich and delicious. Very popular variety. Price, $20 \mathrm{c}$ each; $\$ 2.00$ per dozen.

HIMALAYA BLACKBERRIES. Enorinous bearer; good shipper; fruits large; round berry; very fine for canning and for table use. Price, 20c each; $\$ 2.00$ per dozen.

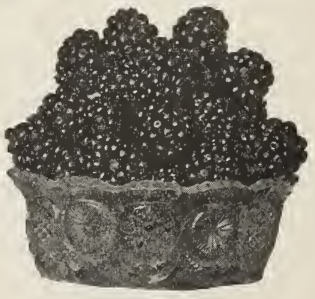

Himalaya Blackberries

MAMMOTH BLACKBERRIES. Immense grower, makes canes 20 feet long in a season; fruits very large, sometimes $21 / 2$ inches long; seeds small; one of the finest black berries in existence. Price, 20c each; $\$ 2.00$ per dozen.

RASPBERRIES, CUTHBERT. Berries very large; deep rich crimson; good for shipping; stands the sun and heat well. Price, $20 \mathrm{c}$ each; $\$ 2.00$ per dozen.

DEWBERRIES, GARDENA. Berries large glossy black; sweet, rich and delicious.
Vines are heavy bearers and growers. Price, 20c each; $\$ 2.00$ per dozen. on 1000 by request.

BLACK CURRANTS. Large and black. Valuable for jams and jellies. One year old, open rooted, $15 \mathrm{c}$ each. Two year old, established in one gallon cans, $25 \mathrm{c}$ each.

RED CHERRY CURRANT. Very large ; deep red; fine for preserves; best market variety. One year old, open rooted, $20 \mathrm{c}$ each. Two year old, established in one gallon cans, $25 \mathrm{c}$ each.

WHITE GRAPE CURRANT. Large; yel lowish white; good table variety; best of all white currants. One year old, open rooted, $20 \mathrm{c}$ each. Two year old, established in one gallon cans, $25 \mathrm{c}$ each.

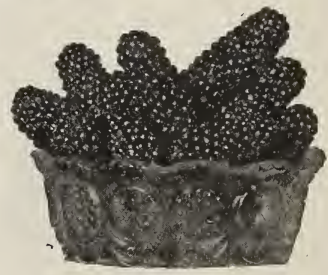

Cory Thornless

DOWNING GOOSEBERRIES. A good variety; shape roundish; skin whitish green and smooth; flesh soft. One year old, open rooted, $20 \mathrm{c}$ each; two year old, established in one gallon cans, $25 \mathrm{c}$ each.

HOUGHTON GOOSEBERRIES. Vigorous grower; abundant bearer; fruit medium size; pale red; sweet and juicy. One year old, open rooted, $25 \mathrm{c}$ each; two year old established in one gallon cans, $25 \mathrm{c}$ each.

JOSSLYN GOOSEBERRIES (Red Jacket). Large size; smooth, prolific and hardy foliage bright, clean and health; a wonderful cropper. Price, 25c each.

STRAWBERRIES. KLONDYKE. A good variety for planting in this vicinity. A great improvement on the old Brandywine variety. Price, $\$ 1.50$ per hundred; $\$ 12.00$ per thousand.

CAROLINA STRAWBERRY PLANTS. The leading variety for home and commer cial purposes, large red berries growing in profusion on strong plants. The Carolina strawberries have been thoroughly tested in strawberries have been thoroughly tested in this vicinity and have given big berrie
Doz., $30 \mathrm{c} ; \$ 2.00$ er $100 ; \$ 15.00$ per 1000 .

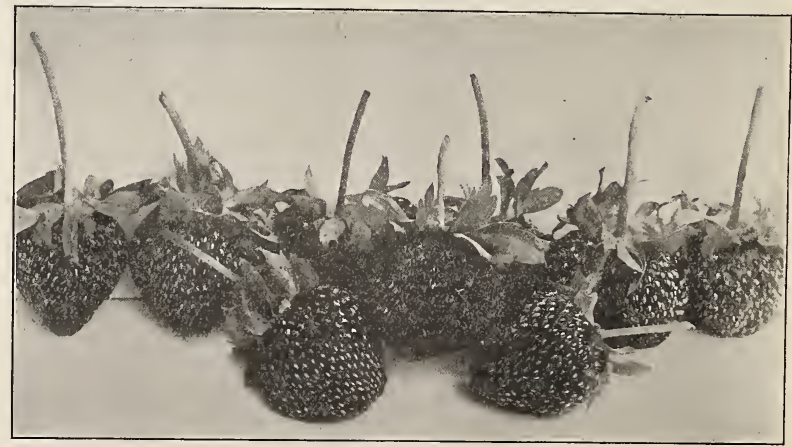

CAROLINA STRAWBERRIES 


\section{Selected Varieties of Citrus and Tropical Fruits}

\section{Economical as well as Ornamental}

Evergreen Fruit Trees are delivered by us balled, and ean be furnished every month of the year. These balls are set in five-gallon eans and a mixture of old manure and shavings is used to pack the ball firmly in the ean. Many advantages are derived from this method of handling. The most important is the fact that it prevents all danger of breaking the ball and losing the fibrous roots which are so essential in helping these trees to start out again. The trees ean be loaded and unloaded from delivery wagons with perfect safety. The faet that we deliver them in this condition is a valuable item for those who wish their trees shipped out of town. These trees begin to make fibrous roots right through the burlap soon after they are put in eans. These fibrous roots help to hold the ball of earth together, which insures safe transplanting. If the can is removed with eare, these trees should keep right on growing. The ean is removed by splitting it open on two sides. Then slide the tree gently into the hole.

\section{Citrus Fruit Trees \\ Oranges}

NAVEL. Fruits of a deep golden color; smooth and solid; thin skin; shape rather oblate; rood size; pulp delicious, sweet and seedless. Trees we offer are from special. ists, and men that grow citrus trees only ists, and men that grow citrus trees only,
trees are well balled and in good conditrees are well balled and in good condi-
tion; two year old buds on three year old stock. Large size, $\$ 2.00$ to $\$ 2.50$ each.

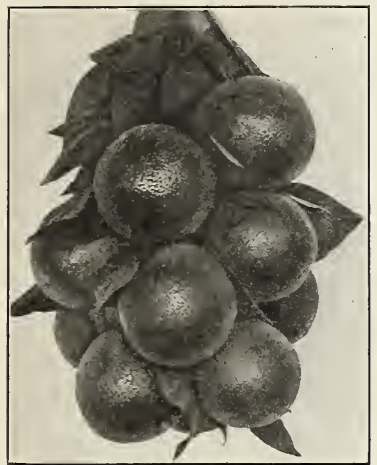

Navel

VALENCIA LATE. Fruit oblate and large ripens very late, holding its fruit in good condition as late as September, coming in when other varieties are gone. Two year old buds on three year old stock. Price, $\$ 2.00$ to $\$ 2.50$ each.

TANGERINE. Fruits medium size; Mandarin type; pulp very sweet; skin thin and separating readily. Price, $\$ 2.50$ each.

KUMQUAT. Fruit the size and shape of a large gooseberry; rind sweet, juicy and delicious. We have a few trees of this va. riety established in large pots. Price, $\$ 2.50$ each.

\section{Lemons}

EUREKA. The best variety for planting in California. The tree is a vigorous grower. Almost thornless and immense bearer. This tree is greatly in demand on account of having flowers, green fruits and ripe ones almost all the year around, and especially making a heavy crop in the heat of the making a heavy crop in the heat of the
summer when lemons are greatly in demand.
Two year old buds on three year old stock. Price, $\$ 2.00$ to $\$ 2.50$ each.

\section{Limes}

THE MEXICAN VARIETY. Thin skinned. Price, $\$ 2.50$ each.

\section{Pomelo or Grape Fruit}

MARSH'S SEEDLESS. Leading variety around Southern California. Fruits medium size; skin very smooth; glossy lemon - yellow in color; pulp juicy; this variety is practically seedless. Fruit will hang on the practically seedless. Fruit will hang on the
tree late in September, retaining its flavor. Tree is very showy with its immense clusters of yellow fruit and abundance of deep green foliage. Two year old buds on three year old stock. Price, $\$ 2.50$ each.

\section{Tropical Fruits}

ALLIGATOR PEAR (Persea Gratissima). Spanish name AVOCADO. Makes a beauti. ful tree, especially adapted to sheltered locations in Southern California. The fruits are large with a greenish brown skin. This are large with a greenish brown skin. This fruit, when well seasoned, makes a most
delicious salad. Budded varieties, $\$ 3.50$ each. Budded trees from four to five feet, $\$ 7.50$ each.

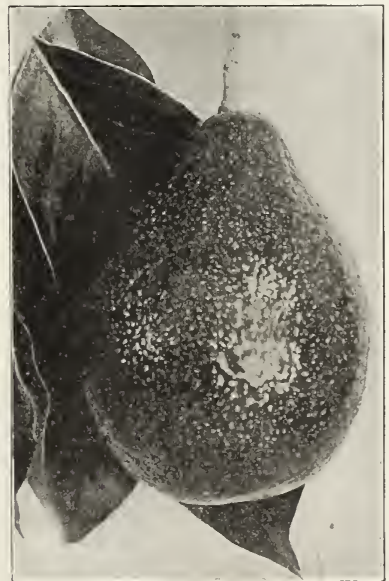

Fuerte Avocado

CHERIMOYA (Anona Cherimolia) Custard Apple. Leaves very broad and aromatic. Fruits vary in size, some weighing as much as two pounds each. The pulp of the fruit resembles custard in consistency and in taste, hence its name "Custard Apple." Plants $2 \frac{1}{2}$ to 3 feet high, $\$ 1.00$ each.

DATE PALM (Phoenix Dectylifera). The date of commerce. Strong young plants in 5 -inch pots, $\$ 1.00$ each.

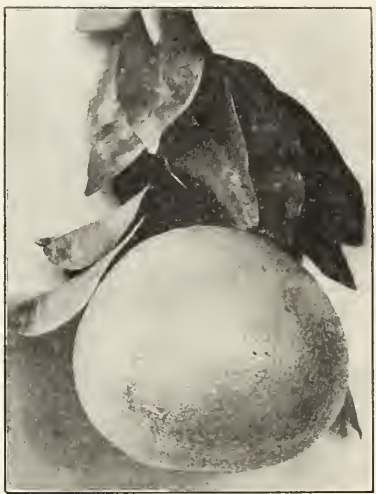

Marsh Seedless Grape Fruit

FEIJOA SELLOWIANA. A small fruit tree introduced from South America. Belongs to the Guava family, but is more hardy The fruit is green and grows to the size of a large plum. The pulp of the fruit is very delicious and highly perfumed. Price, $25 \mathrm{c}$ to $50 \mathrm{c}$ each.

POMEGRANATE. These trees combine the useful and the ornamental. The flowers are very much admired while the fruit is much prized for its piquant flavor. Unsurpassed for jellies, and a delicious morsel eaten out of hand. Plants in 5 gallon cans, $75 \mathrm{c}$ each.

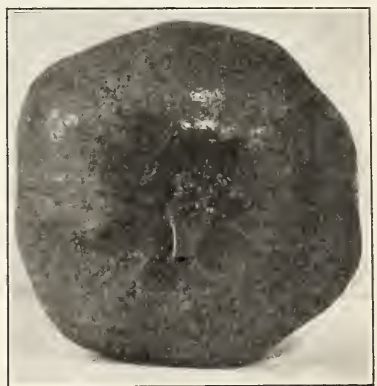

Pomegranate Wonderful 
ABRONIA UMBELLATA (Sand Verbena). Hardy annual. A trailing plant bearing umbels of verbena like rosy lilac blossoms. Package, 10c.

ABUTILON (Flowering Maple; Chinese Bellflower). Half hardy perennial. The flowers are beautifully bell-shaped, and appear in white, yellow, rose and orange. Mixed colors. Package, $10 \mathrm{c}$.

ACHILLEA PTARMICA, THE PEARL (Sneezewort; double white yarrow). One of the best hardy perennials; bears a profusion of small, double, white flowers during the entire season. Fine for cutting and cemetery decoration, Height, $21 / 2 \mathrm{ft}$. Package, $15 \mathrm{c}$.

ACROCLINIUM. Half hardy annual. These are "Immortelles" or Everlasting flowers are "Immortelles" or Everlasting fowers, Grows about 1 ft. high. Per package, Grows about 1 ft. high. Per package,
Double Mixed, 10c; Single Mixed, 10c; Double pink, 10c; Double White, 10c.

ADONIS (Flos Adonis; Pheasant's Eye). Hardy annual. Flowers crimson and small. Seed should be sown in the autumn. Height, $1 \mathrm{ft}$. Package, 10c.

AGERATUM (Floss Flower). Valuable for bedding, as it is literally covered with blossoms all summer. Sow the seed early in the spring, either in boxes to transplant, or outdoors, and thin to 4 to 6 inches. Hardy annual.

Blue Perfection. Deep blue. Height, $1 \mathrm{ft}$. Package, $10 \mathrm{c}$.

Mexicanum (Imperial Dwarf Blue). Height, $1 \mathrm{ft}$. Flowers blue. Package, $10 \mathrm{c}$.

Mexicanum (Imperial Dwarf White). Flowers white. Height, 8 inches. Package, $10 \mathrm{c}$.

Little Dorritt. A perfect mass of blue flowers. Plant is 6 inches high. Pack. age, $10 \mathrm{c}$.

Little Blue Star. Very dwarf. Package, $15 \mathrm{c}$.

AGROSTEMMA (Rose of Heaven). Hardy perennial. This plant has silvery white leaves and red flowers, borne on long, slender stems. Flowers resemble a single pink. Height, $2 \mathrm{ft}$. Package, $10 \mathrm{c}$.

ALYSSUM MARITIMUM. A fragrant, hardy annual, having the odor of honey and bearing spikes of small white flowers, in great profusion throughout the summer and autumn.

Common Sweet. Very sweet honey fragrance. Height, 1 ft. Package, $10 \mathrm{c}$; oz., $35 \mathrm{c}$.

Carpet of Snow (Little Gem). Pure white, very dwarf and sweet scented. The best white flowered border plant. Height, 4 inches. Package, $10 \mathrm{c}$; oz., $75 \mathrm{c}$.

Saxatile. Hardy perennial. A yellowish sort 18 inches tall. Package, $10 \mathrm{c}$.

AMARANTUS. Hardy annuals grown especially for their brilliant foliage.

Caudatus (Love-Lies-Bleeding). Light yellowish green foliage; long, drooping crimson flower spikes. Height, 3 to 4 feet. Package, $10 \mathrm{c}$.

Cruentus (Prince's Feather). Tall spikes of feathery red flowers. Height, 3 feet. Package, $10 \mathrm{c}$.

Tricolor (Joseph's Coat). Plant 3 feet high, with brilliant leaves variegated, red, yellow, green, etc. Package, $10 \mathrm{c}$.
ANCHUSA CAPENSIS. Hardy annual. A clear, bright blue flower with small white eye, resembling a forget-me-not but taller, larger and of brighter color. Height, 2 ft. Package, 10c.

Italica, Dropmore Variety. Hardy perennial. Flowers are of deepest gentian blue and are borne continuously. A good tall plant for the center of a bed. Height, $4 \mathrm{ft}$. Package, $15 \mathrm{c}$.
ANEMONE, SINGLE, GIANT DE CAEN. Half hardy perennial. Cup shaped flowers in blue, red, and white. Bulbs of Anemones are unobtainable now but plants flower in ten months from seed. Package, $10 \mathrm{c} ; 1 / 4 \mathrm{oz}$., $50 \mathrm{c}$.

St. Brigide Irish Anemone. Enormous semi double blooms, the size of tulips, in a great variety of striking colors. Package, $15 \mathrm{c}$.

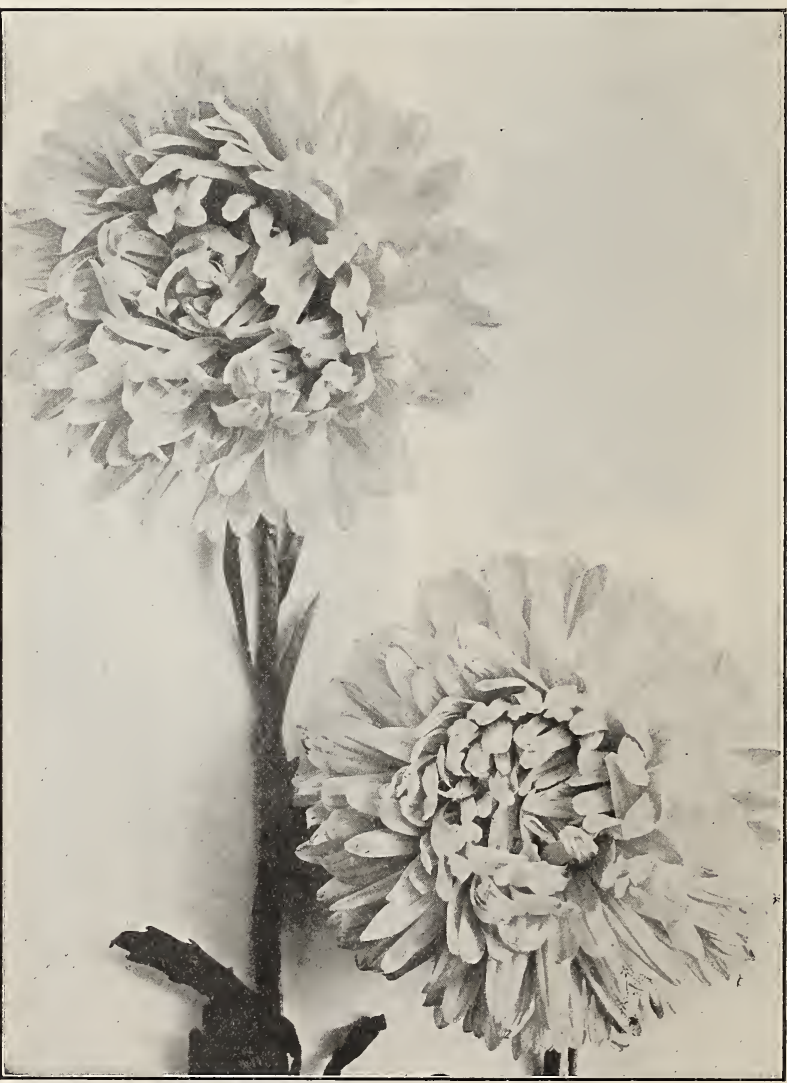

Aster American Beauty 
ANTIRRHINUM. See Snapdragon.

AQUILEgIA. See Columbine.

ARCTOTIS GRANDIS (African Lilac Daisy) Large, brancling bushes, $2 \mathrm{ft}$. in height and breadth. Flowers are pure white on the surface and pale lilac below. Package, $10 \mathrm{c}$.

ARMERIA. A very pretty border plant with grass like foliage. Flowers rose pink,
borne on 4 to 6 inch stents. Package, $10 \mathrm{c}$.

AUSTRALIAN PEA VINE (Dolicbos lignosus). Half hardy perenuial. A rapid growing evergreen climbing perennial, flowering freely in clusters of rose peashaped flowers. For covering arbors, trellises, etc., this is extra fine. Package, $10 \mathrm{c} ; 0 z ., 60 \mathrm{c}$.

ASPARAGUS. Tender perennial. Seeds start slowly and should be soaked in warm water before sowing. Make a pillar climber where there is little frost.

Plumosus robustus. A tall asparagus fern, with delicate feathery foliage. Package, $10 \mathrm{c} ; 100$ seeds, $75 \mathrm{c}$.

Plumosus nanus. A dwarf variety; very delicate and feathery. Package, 10c; 100 seeds, 75c.

Sprengeri (Emerald Feather). Feather leaved, with drooping branches. For hanging baskets. Per package, $10 \mathrm{c} ; 100$ seds, $50 \mathrm{c}$.

ASTER, NEW, AMERICAN BEAUTY. This grand new Aster is one of the most yaluable introductions of recent years and is quite distinct from any other variety. It is similar in growth to the Late Branching Aster but differs in tbat the blossoms are produced on longer and heavier stems. Some of these stems will measure over 2 feet in length. The flowers are produced in succession over a long period; they are very large, perfectly double and of a bright carmine rose shade
similar to the American Beauty rose, a very desirable color in Asters. Package, $25 \mathrm{c}$; $1 / 8$ oz., $60 \mathrm{c}$.

GIANT BRANCHING COMET, or Ostrich Plume Aster. This magnificent strain is without doubt the best of the late flowering Asters for our climate. They grow from 2 to $21 / 2$ feet high, and form strong, much branched bushy plants. The flowers much branched bushy plants. The on long are produced in large quantities, on long wiry stems, and are of immense size, of ten four or five inches across; tbey are of the curled petals. For cutting purposes tbis strain has no equal. We offer them in eight different colors: White, shell pink, lavender pink rose crimson, lavender, dark blue and royal purple. Each, per dark blue and royal purple. Each, per
package, $15 \mathrm{c}$. Mixed colors, package, $10 \mathrm{c}$.
MAMMOTH ASTERS. Twisted Petal Type. Maininoth Asters have petals just a little broader than Crego's and less twisted. Their growth is fairly compact like the old Comet variety. They have fine large flowers, over 4 inches across and some. times 5 inches, borne on long stems. They are entirely new and different froms. They the other asters, and have a great charm the other asters, and have a great charm
in the delicacy of their flowers. Every garden needs some of these new asters. Mammoth White; Mammoth Shell Pink, Mammoth Lavender; Mammoth Rose; Nammoth Lavender; Mainmoth Rose Packages, 20c each.

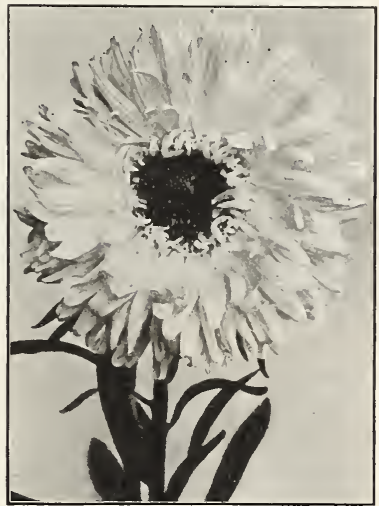

Crego's Giant Asters

CREGO'S GIANT ASTERS. No garden is complete without asters. Crego's are a giant, shaggy petaled kind, with very large flowers baring long twisted petals. The stems are long and the variety is early and branching. Crego's asters are ex ceedingly popular, and this strain has exceptionally fine, flowers. Crego's Giant Crimson ; Crego's Giant Lavender ; Crego' Giant Purple; Crego's Giant Rose-pink Crego's Giant Shell-pink; Crego's Giant White. Six packages of named Crego's asters for $50 \mathrm{c}$. Mixed, package, $10 \mathrm{c} ; 1 / 4$ oz., $60 \mathrm{c}$.
PINK ROCHESTER (Mikado). This variety is the first to bloom of the very large asters. Flowers, often $4 \frac{1}{2}$ inches across, are borne on very long stems. They are pink with age, Package, $10 \mathrm{c}$

SEMPLE'S, or Giant Branching. The plant grows $11 / 2$ feet high and the same in width. The blossoms which are large and full petaled, are borne on long stems or branches. Coincs into flower ten days after the other asters. The petals are Colors: Pink or rose, white, purple, lav. ender, crimson, Mary Semple (very light pink). Package, $10 \mathrm{c}$; 1/2 oz., $50 \mathrm{c}$; collec tion of six varieties,

NEW ENGLAND PERENNIAL ASTER (Michaelmas Daisy). Our splendid autumn flowering asters, greatly improved as to size. Height 4 feet. Blue, lilac and pink. Mixcd, package, $15 \mathrm{c}$.

BACHELOR'S BUTTON. See Centaure Cyanus.

BALLOON VINE, or Love-in-a-Puff. Climbing annual. Package, 10c; oz., 40c.

BALSAM, or Lady's Slipper. A tender annual, with brittle stems and foliage. Grows about a foot high. Flowers, both single and double, in bright colors and variations, are wax-like and growing close to the stem. Package, 10c.

BALSAM APPLE or PEAR. See Momor dica.

BARTONIA AUREA (Golden Bartonia). Hardy annual. A native of California. Bright yellow, single flowers, 2 inches are to remain, since it does not transplant easily. Height 2 feet. Package, 10c.

BELLIS PERENNIS (Double Daisy). Hardy perennial. This giant daisy makes a fine border.

Mammoth Pink, White and Mixed. Pack age, $10 \mathrm{c} ; 1 / 8$ oz., $75 \mathrm{c}$.

Lawn Daisy. ..Mixed. Package, 10c; 1/8 oz. $45 \mathrm{c}$.

BORDER PINKS. See Dianthus plumarius BOSTON, OR JAPANESE IVY (Ampelopsis Veitcbii). The popular ivy which cover so many buildings. It clings to brick and wood witbout support. The leaves are heart shaped and are off the vine for only two months in the winter. Package, $10 \mathrm{c}$; oz., 60c.

BROWALliA. Half hardy annual. Makes a fine bedding plant. Blooms profusely. The flowers are bright ultra marine blue, and also sky blue with white center. Mixed, package, $10 \mathrm{c}$.

\section{Proper Planting and Culture of Annuals}

The following directions while given for Asters apply to most all annuals and perennial flowers. The time of sowing varies according to the different species and varieties, and we advise our customers to consult the Garden Calendar on the first pages of this book in order to plant these different flowers in the proper season. Asters, especially the branching varieties, are the leading annuals for Southern California. They come in bloom just before tbe Chrysanthemums, and at a time when flowers are very scarce. Owing to the fact that the cultivation of Aster is very simple, and also that the cut flowers retain their beauty for a considerable lengtb of time, they are considered one of the most desirable of annuals for the smallest garden as well as tbe largest parks. Sow the seed in January, February or March in light sandy loam. Transplant as soon as the plants have four or five leaves. Never transplant them after the flower stems begin to show. They will not branch out nor produce good flowers if handled at that period. Asters like the full sunshine, a rich garden soil and plenty of irrigation and cultivation.

SEEDING. The soil in the seed flats should be composed of good quality of loam, mixed with sand and a small amount of old rotted sheep manure, the whole mixture to be screened through a balf inch mesh. Fill the flat nearly full, then pack down firmly with a piece of board and sow the seed very thinly on this smootb surface. For a covering use very fine screened sand. Use a fine nose on your watering pot. Never use the hose on seedlings, regardless of the fine nozzle you may have. Set the flat out of doors in some old hotbed frame or sheltered location where the wind and sun will not dry it out. The cooler you can keep these little seedlings without exposing them to the frost, the stronger plants tbey will produce. As soon as tbey have three or four leaves, they should be transplanted 100 to a flat or in beds in the open especially arranged for this transplanting.

FERTILIZING. Asters are great feeders and respond to the use of fertilizers in a surprising way. The ground should be spaded very deep, and 100 pounds each of old rotted sheep manure and bone meal should be applied to each tbousand square feet. It is a great mistake to use stable manure on Asters. Sometimes after weeks of labor and expense in raising these plants and setting them out in beds where stable manure has been used, one is greatly discouraged and disappointed to see the little plants die, one after another, and to find in pulling up these dead plants, tbat a little wire worm has hollowed out the collar of the plant and caused it to die. Stable manure produces this wire worm.

PLANTING. The planting, whether in beds or fields, sbould be done with great care. If possible, a transplanter should be used for this purpose so they can be taken out with as many of the little roots as possible from the flats or beds. Set the plants in the ground up to the first leaf. Press the ground tigbtly with the hands, and water immediately. A top dressing of sheep manure is given, and later on wben the buds begin to appear, nitrate of soda sbould be applied and raked in immediately. Tbis should be used at the rate of one pound to every four hundred square feet. Aster plants are tender, and greatly relisbed by snails and ground worms. Use tobacco dust freely, which will kill the snails as well as lice or green fly. 
BEGONIA. Usually grown in the greenhouse. Some varieties are especially attractive on Some varieties are especially attractive on have esquisitely beautiful wax-like flowers, have esquisitely beautiful wax-like flowers,
both single and double. The seed is very both single and double. The seed is very
small and rather difficult to germinate and inust be planted in boxes or pots indoors. It is also very expensive, some strains being worth more than their weight in gold.

FIBROUS ROOTED VARIETY. Fine for outdoor culture, having beautiful leaves and bearing clusters of small waxy flowers.

Vernon. Half hardy perennial. Deep red flowers and dark purple foliage; often used for borders and for bedding. Package, $10 \mathrm{c}$.

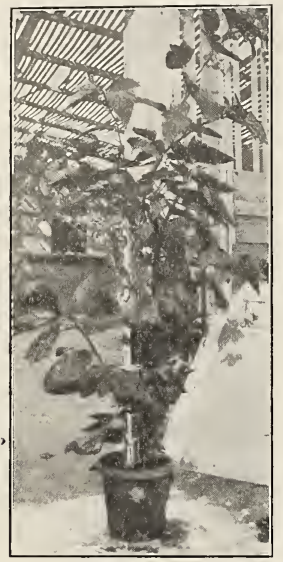

Begonia rubra

TUBEROUS ROOTED VARIETIES. For greenhouse and pot culture, having large,
beautiful flowers with four petals in brilbeautiful flowers with four petals in bril-
liant colors. Many prefer to start bulbs in December and January.

Double Mixed. All the best varieties. Pack age, $50 \mathrm{c}$.

Single Mixed. Finest large flowers; single varieties. Package, $50 \mathrm{c}$.

BRACHYCOME (Swan River Daisy). Hardy annual. Produces an abundance of pretty blue and white flowers. Height, 8 inches. Package, 10c.

CALIFORNIA POPPY. See Escholtzia.

CALENDULA (Pot Marigold). Very hardy annual, 1 foot high, blooming freely a any time of year, including winter, an for several months. Is of the easiest culture and is desirable for rather inferior soils, where less sturdy flowers do not thrive.

Double Mixed. A good mixture of eight to ten different shades of yellow, some clear colors and some shaded and striped. Package, $10 \mathrm{c}$.

Lemon King. Large, very double, lemon flowers. Package, 10c.

Meteor. Yellow flowers, striped with orange. Package, $10 \mathrm{c}$.

Prince of Orange. A fine deep orange, double. Package, 10c.

CANARY-BIRD FLOWER (Tropaeolum canariense). A tender climbing annual of the nasturtium family. Blossoms have curiously wrinkled petals and are light yellow. Soak seed over night before planting. Package, 10c.
CANDYTUFT (Iberis). Very hardy, easy to grow, and very fragrant. The blossoms arew, and very fragrant. The blossons are borne on long spikes, and the newer varieties are quite large flowering and
very fragrant. Valuable for bedding or very fragrant.
massing and for cutting. Height 6 to 15 inches.

Common Sweet Scented. Small white flowers. Package, 10c; oz., 30c.

Carmine. Branching. Package, 10c.

Lilac. Branching. Package, $10 \mathrm{c}$.

Purple. Branching. Package, 10c.

White Rocket. Long spikes and large flowers. Package, $10 \mathrm{c}$.

Giant Hyacinth Flowered (Improved Em press). Very large heads and long spikes of white flowers. An improved strain of Giant Empress and excellent for cut flowers. Package, $10 \mathrm{c}$; $1 / 4 \mathrm{oz}$., $25 \mathrm{c}$.

Mixture of All Colors. Package, 10c.

CALLIOPSIS. Blossoms single and about 2 to 4 inches in diameter. Hardy annual.

Atrosanguinea. Dark maroon. Plant is tall and flowers are small. One of the old fashioned flowers. Package, $10 \mathrm{c}$.

Golden Wave, A large flowering light yellow variety with maroon eye Package, $10 \mathrm{c} ; 1 / 2 \mathrm{oz}, 25 \mathrm{c}$

Bicolor Hydrida Semiplena. Semi double flowers of garnet and yellow. The old fashioned small Coreopsis. Package, 10c.

Mixed. A gorgeous mixture of golden yellow, brown, maroon and other shades. Package, $10 \mathrm{c}$

Lanceolata. See Coreopsis.

Tiger Star (C. nana compacta radiata). Package, $10 \mathrm{c}$.

CANTERBURY BELLS (Campanula Medium. A hardy biennial, blooming the second year from seed, or the first year if sown early, Fesily grown and preferring rown early. Easily grown and preferring rich, moist soil. Grows about 3 feet high blue, white, purple and deep pink flowers. Single, mixed, single white, single pink, single blue, double mixed. Each package, $10 \mathrm{c}$

Carpatica (Carpathian Harebell). Fine for rockeries, edges and beds. Blue and rockeries, edges and beds. Blue and package, $10 \mathrm{c}$.

Cup-and-Saucer type. In this variety the outer petal forms a brim like a saucer. Mixed, light blue, white, pink. Per package, $10 \mathrm{c}$.

Persicifolia (Peach bells). Perennial. Large flowered. Height, 4 feet Package, $10 \mathrm{c}$

Pyramidalis (Chimney Bellflower). Peren nial. Large bells on 6 foot spikes; bloom late. Blue, white, per package, $10 \mathrm{c}$

Six 10c packages of any of above for 50c.

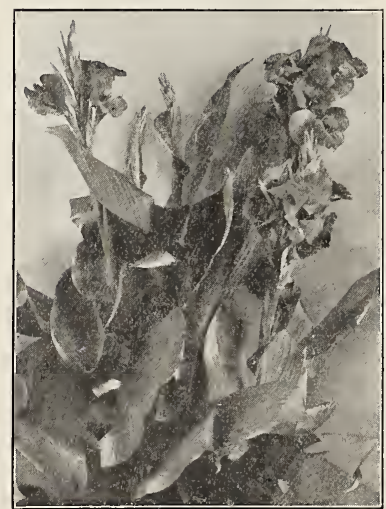

Canna
CANNA. Mixture of the popular varieties. Flowers red or yellow, All plants have large ornamental leaves and give a tropical effect. Bronze leaved, package, $10 \mathrm{c}$; green leaved, package, $10 \mathrm{c}$; mixed, package, $10 \mathrm{c}$.

JAPANESE BELLFLOWER (Platycodon grandiflora). Perennial. A giant Bell-
flower growing 2 feet tall and covered all summer with large, steel blue flowers. Package, 10c.

CASTOR OIL BEAN (Ricinus). This has large leaves and a tropical appearance. All it requires to make it flourish is heat It is a quick growing annual, 6 to 15 inches tall. Leaves are green or reddish. Mixtures of all varieties, per package, $10 \mathrm{c} ;$ oz., $25 \mathrm{c}$.

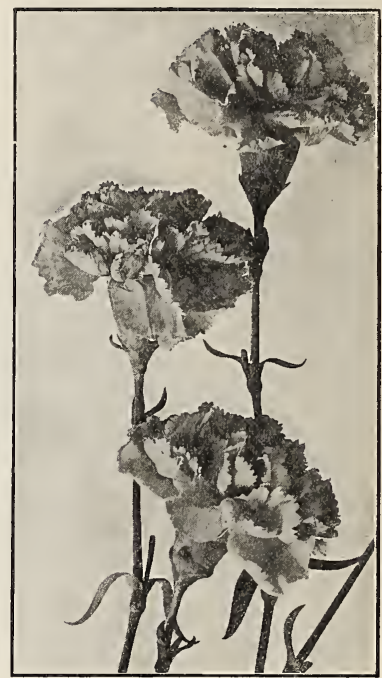

Carnation Marguerite

CARNATIONS. Carnations may be had in ll gardens. The florists' varieties are propagated from plants. Sow the seed propagated from plants. Sow the seed
early in the year and transplant in March or April. Half hardy annual.

Chabaud's Everblooming. Earliest dwar French type of perpetual blooming carnations, flowering in five to six months after seed is sown. The flowers are double. Mixed colors, package, $15 \mathrm{c}$.

Malmaison Giant. Mixed colors. Package, $15 \mathrm{c}$.

Picotee. Extra fine, double, mixed. White, edged with colors, or striped and splashed. Contains many rare sorts never seen at a florists. Package, 25c.

Giant Grenadin, This is an extra fine double variety, far superior to the Marguerite carnation. It comes in red, white, yellow and pink. Package, $15 \mathrm{c}$.

Marguerite Carnation. Mixed only. Package, $10 \mathrm{c}$.

CockscomB (Celosia Cristata). A half hardy annual, growing 6 to 8 inches high, bearing a wide, wavy blossom that resembles a cock's comb. In brilliant colors; fine for unassing or border work.

Dwarf Mixed. Several shades of red and yellow. Package, 10c.

Dwarf New Giant Empress. A rich, crimson variety with dark foliage and very wide combs. Per package, $15 \mathrm{c}$. 


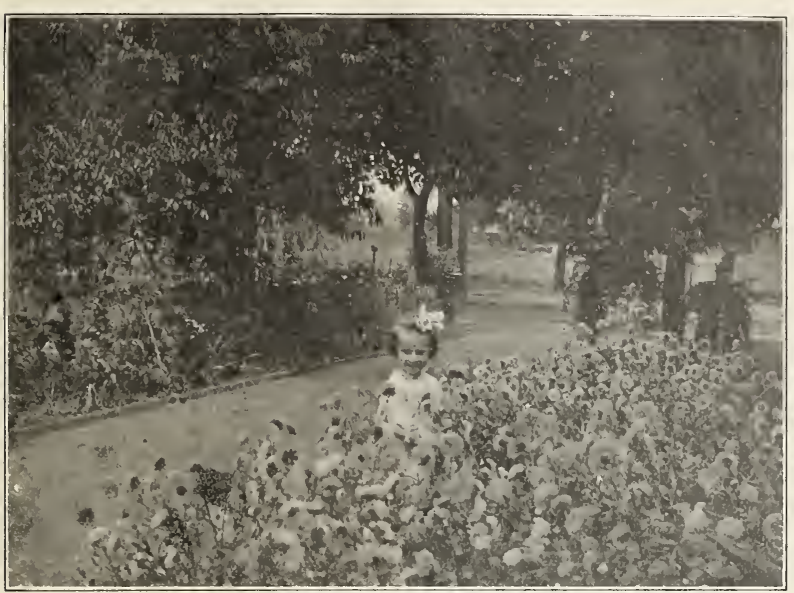

An old-fashioned Flower Garden

CARDINAL CLIMBER. A new and abso. lutely distinct annual climber, being the result of a cross between Ipmomoea quamoclit, "Cypress Vine," and Ipomoea quamoclit, We consider this the most coccinea. We consider this the most introduced. It will no doubt attract uniintroduced. It will no doubt attract uni-
versal attention, not only for the beauty and number of its bright, cardinal red flowers, but for its hardiness, its quick growth, reaching a height of 20 to 25 feet in a short time, and also for its rich green, laciniated foliage, which resembles that of a fine Japanese Maple. The flow that of a fine Japanese Maple. The flow ers, which are about $11 / 2$ inches in di-
ameter, the tube being about $11 / 4$ inches in length, are borne in clusters of from 5 to 7 and their vivid cardinal red color against the abundant dark green foliage is most effective. This vine thrives best in a good soil and a warm, sunny situa. in a good soil and a warm, sunny situa. tion. Sow the seed in the open ground as soon as the weat
settled. Package, $15 \mathrm{c}$.

FEATHERED COCKSCOMB (Celosia Plumosa). The plumes are splendid and 2 to 3 feet tall. This strain is fine; colors bright red and bright yellow.

Magnificent (Thompson's). A new variety, superior to the older sorts, bearing grand superior to the older sorts, bearing grand spikes; flower
Package, 10c.

Magnificent, Crimson. A bright shade Package, 10c.

Magnificent, Golden Yellow. A fine contrast to the crimson. Package, 10c.

Mixed. Package, 10c.

CHINESE WOOL FLOWER (Celosia Childsii). New variety. Has a crimson, globe shaped head, like a ball of crimson silky wool. Package, 20c.

CANDIDISSIMA (White leaved; Dusty Miller). Perennial. Grown for its silvery white foliage; leaves broader and less cleft than Gymnocarpa. Height, 8 inches. Package, $10 \mathrm{c}$.

CHRYSANTHEMUM. The double perennial Chrysanthemum so much admired at the florists is the sort we call Japanese Hy brids. We sell plants of these late in the spring. The annual varieties are smaller flowered, upright in growth, and of easiest flowered, upright in growth, and
culture, coming into bloom early.

Annual Varieties. Seeds should be planted early and the plants set out in April. The single varieties sometimes called "Painted Daisies." Very attractive. Height, 11/ to 3 feet. Mixed. Package, 10c.
CENTAUREA. Centaureas embrace a num ber of species, some being grown only for their foliage. Sow the seed early in boxes and transplant in March or in the open in April. All inake excellent cut open in April. All make excellent cut Height, $11 / 2$ to 2 feet.

Cyanus (Bachelor's Button; Bluebottle; Cornflower). Of easy culture. Sow the seed where it is to remain and thin plants to 3 to 4 inches apart. Mixed, package, $10 \mathrm{c}, \mathrm{oz}, 40 \mathrm{c}$.

Blue, Single. The most popular blue cut flower. Package, $10 \mathrm{c}$.

Blue, Double. New and extra fine. Package, $10 \mathrm{c} ; 1 / 2$ oz., $50 \mathrm{c}$.

Pink. Package, $10 \mathrm{c}$

Wbite. Package, $10 \mathrm{c}$.

Imperialis (Royal Sweet Sultan). The finest of all Sweet Sultans. The plants are very strong and bear giant flowers on stiff, long stems; excellent for cutting, lasting a week when cut.

Purple Shade. Package, 10c.

White. Package, 10c

Pink. Package, 10c.

Lavender. Package, 10c.

Suaveolens. Yellow, Package, 10c

Mixed. Package, 10c.

CHEIRANTHUS ALLIONII. Perennial. This has gorgeous orange flowers resembling wallflower. Although a perennial, it flowers easily from seed the first sumit flowers easily from seed the first summer. Beautiful for a border or in a
rockery. Height, 12 inches. Package, $10 \mathrm{c}$.

CORONARIUM, Double, Mixed. Package, $10 \mathrm{C}$

Tricolor Burridgeanum. Daisy like flowers with yellow center, crimson maroon band, and white tips. Package, 10c.

Tricolor, Mixed. Package, 10c

Tricolor, Eclipse. Golden yellow daisy like Howers with purple ring; very striking. Package, $10 \mathrm{c}$

Evening Star (Helios). This is a tall plant with large, Marguerite like flowers of pure golden yellow, 3 inches in diameter. pure golden yellow, lent for cutting. Package, $10 \mathrm{c}$.

Morning Star. Like Evening Star, only of different color. This is a soft yellow or primrose color. Package, 10c

Northern Star. Another variation of these beautiful Marguerites. Fine, large, ivory white flowers with sulphur zone. Package, $10 \mathrm{c}$.

Six $10 \mathrm{c}$ packages of the above named Chry santhemums for $50 \mathrm{c}$.
CINERARIA. IIeads of daisy like fowers in purple, red, blue or white with a dark eye surrounded by a ring. Does very well in shaded positions, under trees, etc. Cinerarias are mucli prized as pot plants and do well in a cool greenlouse. Sow seed in summer in boxes or cool linuse. lleight, 1 to 2 feet. Tender perennial.

Hybrida, Mixed. The best variety, having large flowers of brilliant colors. Pack. age, $25 \mathrm{c}$.

Grandiflora, Dwarf, Mixed. Package, 35

Grandiflora, Stella. Twisted petals, Package, $35 \mathrm{c}$

Maritima Candidissima (Dusty Miller). Silvery foliage; hardy border plant. Ileight, $21 / 2$ feet. Package, $10 \mathrm{c}$.

CLARKIA. This hardy annual is of easy cul ture, bearing bright rose, white or purple flowers in great profusion. The single type is native to California and is a wild flower. Seed can be sown almost any time, but if sown in the fall will give early blossoms in the spring. The Elegans varieties grow two feet tall with fowers in spikes. The seedlings sbould be pinched back twice to make bushy plants, once to 3 inches and again to 9 inches.

Elegans, Carmine Queen. Just loaded with double carmine flowers along the stem. Package, $10 \mathrm{c}$.

Elegans, Double, Mixed. Package, 10c.

Elegans, Single, Mixed. Package, 10c.

Elegans, Vesuvius. Bright coral pink blooms, $11 / 2$ inch across, shading deeper and more intense at center. They are very double, like rosettes and are borne an inch apart on stiff, red stems which flower. IIeight, 15 to 18 inches. Pack. age, $10 \mathrm{c}$.

Pulchella, Tom Thumb. Double, white. Package, 10c.

Salmon Queen. Package, 10c

COBAEA SCANDENS. Half hardy peren nial. A fine large purple flowered vine. Package, $10 \mathrm{c}$.

COCKSCOMB. See Celosia cristata.

CONVOLVUlus. See Morning Glory.

COREOPSIS. Hardy perennial. No flowers bloom longer during the whole season than Coreopsis. It is a most excellent cut flower, lasting well. Flowers bright yellow, large and showy. Easily grown from seed. Height, $21 / 2$ feet. Package, $10 \mathrm{c}$.

Lanceolata Grandiflora. Package, 10c

COLEUS. A tender perennial grown for its beautiful, bright colored velvety leaves. Valuable for window garden or pots, and can also be grown outdoors if taken up in winter. Heigbt, 10 to 18 inches. Package, $25 \mathrm{c}$.

COLUMBINE, AQUILEGIA. A hardy perennial growing about 2 feet high and bearing flowers of a great variety of colors on long, smooth stems. Stands partial shade very well.

California Hybrida. Large yellow flowers, orange spurs. An improvement on our native sort. Package, $15 \mathrm{c}$.

Chrysantba. Pure golden yellow single flowers, long spurs. Height, 3 feet. Package, $10 \mathrm{c}$

Caerulea (Rocky Mountain Blue Columbine). Fine deep blue and white flowers, long spurs. Package, 10c.

Rose Queen. Beautiful large pink flowers with long spurs. Package, 15c.

Skinneri (Mexican Columbine). Flower crimson and light green; very handsome and quite distinct; spurs and sepals long. Height, 3 feet. Package, 10c.

Long Spurred Hybrids, Mixed. Showy. Package, $10 \mathrm{c}$.

COLLINSIA. A free flowering and easily grown annual, reachiug a height of 1 to 2 feet. Flowers white, crimson, purple, etc. A California wild flower. Mixed. Pack age, $10 \mathrm{c}$. 
cosmos. One of the very finest late sum mer and fall flowers, and an excellent cut flower. The bushes grow tall, 6 to 8 feet, and are loaded with large showy blossoms, 5 inches in diameter, in white, pink or crimson. Cosmos should be in pink or crimson. every garden. Sow the seed early and
transplant, or sow later in spring where it is to remain. Hardy annual.

Double Pink Beauty. Clear pink, with double crest. Package, 15c.

Double White Queen. Pure white. Package, $15 \mathrm{c}$.

Early Varieties. This strain is truly giant and very early. Flowers in 75 days from seed.

Early Crimson. Package, 10c.

Early Pink. Package, $10 \mathrm{c}$.

Giants of California. Pink and crimson. Package, 10c ; oz., 50c.

Klondyke. A late blooming variety with bright yellow blossoms. Package, 10c.

Cypress Vine (Ipomoea Quamoclit). A tender, climbing annual, with soft fern like foliage and small star like flowers in red, pink or white. Mixture of all colors. Package, 10c.

DAHLIA. Dahlias will bloom the first year from seed, and while they do not come true to variety they are very interesting to grow. Single mixed; double mixed, to grow, Single mixed; double

Hybridized Mixed. Special hand hybrid ized seed. Many varieties of prize winning dahlias have been produced in California from our hybridized seed. Package, $35 \mathrm{c}$.

DAISY, SHASTA. A fine perennial plant, bearing large, white, single blossoms, with yellow centers; an excellent cut flower. Soak seed in warm water before sowing. Package, 10c.

Alaska. One of Burbank's creations. Package, $15 \mathrm{c}$.

Double. See Bellis Perennis.

DIANTHUS, PINKS. Nothing is prettier or more satisfactory than old fashioned Japanese pinks. They should be in every garden. They are hardy, about 1 foot in height, and bear beautifully colored single and double blossoms in profusion al summer. Sow seed early in boxes and transplant, or sow in rows where the plants are to remain and thin. See also plants are

Chinensis (China or India Pink). Double White. Package, 10c.

Double Mixed. Package, 10c

Heddewigii (Japanese Pink), Finest single mixed. Package, 10c.

Finest Double Mixed. Package, 10c

Diadematus (Double Diadem Pink). Large double flowers in many colors. Package, 10c.

Mourning Pink. Very dark crimson, margined pure white. Package, $10 \mathrm{c}$

Laciniatus. Single fringed pink; single fringed white; single fringed mixed. Pe package, $10 \mathrm{c}$.

Imperialis (Double Imperial Pink). Very large. Package, $10 \mathrm{c}$.

Plumarius (Grass Pink; Pheasant Eye Scotch Pink). A single hardy perennial pink with light colored flowers having parker center; various colored. Thi darker center; various colored. makes a fine border or flowering
Constantly in bloom. Package, 10c.

Plumarius, Double (Double Clove Pink). A double flowered sort, in various colors like the single. The foliage makes a pretty border: flowers delightfully close pretty border; flowers
scented. Package, 10c.

DIDISCUS COERULEUS (Queen Ann's Blue Lace) Though not new this valu Blue Lace). Though not new this valuable annual has only recently been introduced into California. The plants are of upright growth and produce numerous
heads of sky blue flowers. It succeeds well in the open ground and also makes an excellent pot plant. Package, 25c.

DUSTY MILLER. See Centaurea and Cineraria.
DIGITALIS, FOXGLOVE. Grows usually about $3 \frac{1}{2}$ feet, although in very rich soil it sometimes reaches 6 feet. The bell shaped flowers are borne on long spikes. Thrives best in cool, shady locations. Hardy perennial.

Pink. Mottled. Package, 10c.

Purple. Package, 10c.

White. Package, $10 \mathrm{c}$

Mixed. Package, $10 \mathrm{c}$; $1 / 2$ oz., $60 \mathrm{c}$.

DIMORPHOTHECA AURANTIACA HY BRID. Hardy annual. Beautiful flowers in all shades from white to cream, yellow and salmon. Package, $10 \mathrm{c}$.

Dolichos (Hyacinth Bean). Tender annual climber and very rapid growers. Sow seed in open ground late in April.

Lablab. Mixed. Package, 10c.

ESCHSCHOLTZIA (California Poppy). The California Poppy is an exceptionally bright and handsome flower. It adorns bright and handsoine flower. It adorns
the fields and railway embankments. If the fields and railway embankments. If your premises have a wild or uncultivated
plot, by all means plant some Eschscholtplot, by all means plant some Eschscholt-
zia seed. It grows easily and once seeded will reseed itself. Sow the wild sort by the pound over the hill sides. Multiply the native flowers by the thousands. The leaves of the Eschscholtzia are cut fine and feathery. Sow in the fall out in the

open for the plants. Do not transplant well. Height, 1 to $1 \mathrm{t} / 2$ feet. Hardy annual.

Californicia. The bright, orange yellow, wild variety. Package, 10c ; oz., 30c ; $1 \mathrm{~b} ., \$ 2.75$.

Carmine King. There is nothing prettier than this carmine rose Eschscholtzia. Package, $10 \mathrm{c}$; oz., 80c.

Crimson Flowering. Package, $10 \mathrm{c}$.
Chrome Queen. Light yellow with just a shade of apricot, a wonderful color; flowers frilled. Package, 10c.

Crocea. Puredeep orange. Package, $10 \mathrm{c}$; oz., 80c.

Erecta, Mandarin. Brownish gold; erect plant. Package, 10c.

Extra Golden. A fine selection of the dark wild California Poppy. This is the finest colored Eschscholtzia and its richness of color is unequaled. Should be in every garden. Package, 10c; 1b., \$3.

Golden West. Very large, orange coiored blossoms, shading to canary yellow at the edges. Package, 10c.

Mandarin. Blossoms a re copper colored outside and bright yellow inskde the petals. Package, $10 \mathrm{c}$; oz., $50 \mathrm{c}$.

Mikado. Orange crimson. Package, 10c.

Purple Glow. Reddish purple. Package,

Rose Cardinal. Creamy rose. Package, 10c. Tango. Bronzy red overlaid terra cotta. Package, 10c.

Vesuvius. Red and gold. Package, 10c.

White. Large ivory-white. Package, 10c.

FEVERFEW (Matricaria capensis). Called "Double Feverfew." A plant growing $11 / 2$ feet high and bearing profusely pure white, very double flowers. Package, 10c. See also Pyrethrum for edging varieties.

FOUR O'CLOCK. Hardy annual. Seed should be sown in the open and thinned to one foot. An old fashioned favorite, with trumpet-shaped flowers freely borne.

Mixture of colors. Package, 10c; $1 / 2$ oz. $25 \mathrm{c}$.

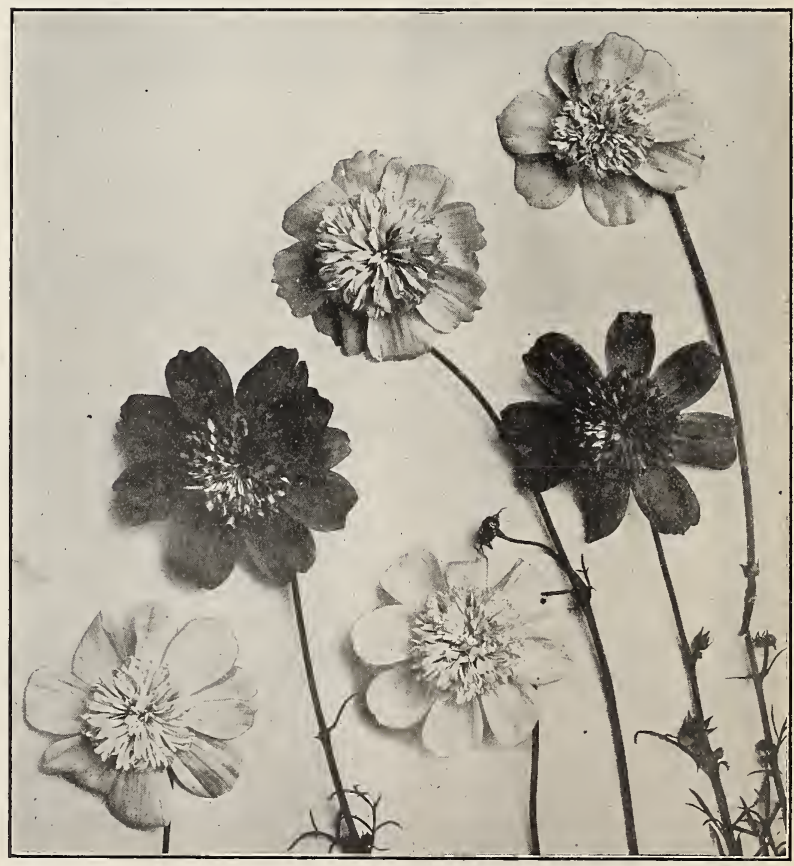

Anemone Flowered Cosmos 
FORGET-ME-NOT (Myosotis). A favorite old fashioned, bearing in profusion, es. pecially in fall and spring, clusters of dainty, blue, five petaled blossoms. It thrives in the shade or open border, but flourishes best in a moist shady situation. Hardy perennial.

Alpestris. Blue. Package, 10c ; 1/4 oz., 40c. Indigo-blue. A new dark blue color. Package, $10 \mathrm{c}$.

Rosea. Pink flowering. Package, 10c.

Wbite. Package, $10 \mathrm{c}$.

Victoria, Large flowers in heads of bright azure blue Plant symmetrical, dwarf and strong grower; good for edgings. Package, 10c.

Dissitiflora, Perfection. Of dwarf, compact habit; flowers profusely; looks like a sheet of blue. One of the best Forget me-nots. Package, 15c.

FOXGLOVE. See Digitalis.

GAILLARDIA. A very showy garden plant with brilliant flowers in scarlet and yellow, blended and shaded. Blooms freely from early summer till autumn on long, slender stems. Both single and double varieties are hardy. Height, $1 \frac{1 / 2}{2}$ to 2 feet.

Double Mixed Annual (G. picta Lorenzianna). Package, 10c.

Grandiflora. Single perennial variety with blooms of varying shades of reddish brown and yellow. Package, 10c.

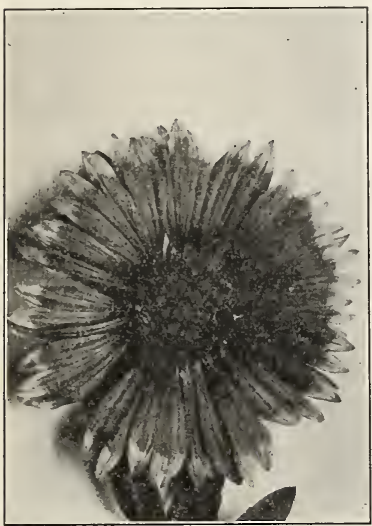

Gaillardia Grandiflora

GENTIANA ACAULUS (Gentian). Hardy perennial. Intense blue flowers with yel-

GERANIUM. Half hardy perennial, The very well known Geranium, the one commonly seen is the variety Zonale.

Apple-scented. Very fragrant leaves. Package, $25 \mathrm{c}$.

Lady Wasbington (Fancy Pelargonium). Handsome, large flowered sort in many colors and with beautiful markings. Package, $25 \mathrm{c}$.

Zonale. Mixed. Package, 10c.

GERBERA. See Transvaal Daisy.

GEUM, MRS. BRADSHAW. A brilliant scarlet cardinal flower the size of a large carnation, which it somewbat resembles. Package, 10c.

GODETIA. Tall sorts, fine mixed. Package, $10 \mathrm{c}$.

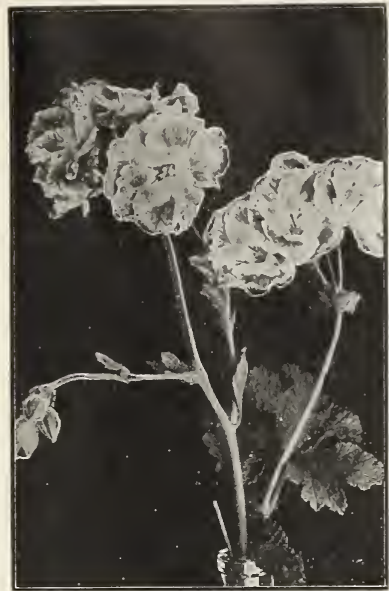

Lady Washington Geranium

GILIA. A hardy annual, growing 1 foot ligh, with white, lilac or rose-colored flowers. A native of California. Valuable flowers. A native of California. for rockwork or borders. Sow
the fall. Mixed. Package, 10c.

Achillearfolia. Hardy annual. This pretty Gilia is common about San Francisco on the hills and sandy ground. Flowers come in clusters $1^{1 / 2}$ inches across and come in clusters $1 / 2$ inches across and
often give a blue look to the fields. often give a blue look to
Height, 1 foot. Package, $10 \mathrm{c}$.

AMOENA. Our pretty wild flower known as "Farewell to Spring." Deep rose colored flowers. Height, 12 to 30 inches. Pack age, $10 \mathrm{c}$.

Duchess of Albany. Tall; white. Package, 10c.

Lady Albemarle. Tall; dark crimson. Package, $10 \mathrm{c}$.

Liberty Bell. Double; bright carmine, flushed rose. Package, $10 \mathrm{c}$.

Schamini. This plant is covered with semidouble clear light pink blossoms, $21 / 2$ inches across. A charming flower. Height, 2 feet. Package, 10c.

GOMPHRENA (Globe Amaranth). Hardy annual. "Everlasting" with round heads about 1 inch in diameter, rose, yellow, or wbite. Height, 8 incbes. Package, 10c. Mixed, $10 \mathrm{c}$

GOURDS (Mixed Ornamental Varieties. Mixed varieties, odd, very ornamental. Package, 10c.

Calabash or Pipe Gourd. Package, 10c.

Chinese Bottle. A useful variety; large bottle-shaped shell.

Dish-cloth or Luffa. The inside lining makes a sponge; very useful. Package, 10c.

Dipper or Sipbon. Can readily be made into a dipper. Package, $1 \mathrm{Uc}$.

Hercules' Club. Four feet long; club shaped. Package, 10c.

Nest-egg. Like a hen's egg and frequently used for nest eggs. Package, 10c.

Sugar Trough. Useful for buckets, holding from 2 to 10 gallons. Package, 10c.

Turk's Turban. Red, green striped, etc. Small. Package, 10c.

GYMNOCARPA. Perennial. Called "Dusty Mfiller." Leaves silvery gray, deeply cleft. Height, $1 \frac{1}{2}$ feet. Package, $10 \mathrm{c}$.
GYPSOPHILA (Baby's Breath). Florists all use this to make up their boquets. The plant is feathery and has small white flowers. Mfost easy to grow. Ileight, 2 to 3 feet.

Muralis. Pink flowers. A fine border plant. Height, 6 inches. Package, $10 \mathrm{c}$.

Paniculata. liardy perennial. Fine for bouquets; white flowers. This is especially feathery and delicate. Package, 10c.

Elegans grandiflora alba. This is an in proved Elegans with larger flowers ant pure white. Package, 10c.

Elegans rosea. A beautiful soft pink. Package, $10 \mathrm{c}$.

HELENIUM AUTUMNALE SUPERBUM. A showy perennial, 5 to 6 feet tall, producing large, deep yellow, single flowers during the summer and fall. Fine for cutting. Package, $10 \mathrm{c}$.

HELIANTHUS. See Sunflower.

HELICHRYSUM (Everlasting F1ower). Hardy annual. Is the best and most satisfactory of the Everlasting Flowers and makes a very handsome dried boquet. makes a very handsome dried boquet. Height, 3 to 4 feet. Bronze, pink, red,
salmon and monstrosum, mixed. Package, $10 \mathrm{c}$.

HELIOTROPE. Half hardy perennial. Beautiful porch plant 4 to 8 feet tall. The fragrant flowers are small and come in clusters. Blooms the first season from seed if sown early. As it forms a large plant it requires a roomy situation. Can also be grown as a pot plant. Finest mixed. Package, $10 \mathrm{c}$.

HESPERIS. See Sweet Rocket.

HOLLYHOCKS. Some grow to the top of the second story window and in some gardens they grow only 8 to 10 feet tall. The double ones are usually about 6 feet tall. Hollyhocks were in all the old gardens. Nothing makes a better boundary. Our doubles are very fine indeed. Hardy perennial.

Double Varieties. Black, rose-pink, white, blood-red, canary-yellow and mixed. Per package, $10 \mathrm{c}$.

Single Varieties, Mixed. The old fashioned blossoms in all colors. Per package, 10c.

Allegbeny. Mixed. The semi-double, fringed variety. An artistic and pretty sort. Package, 10c.

New Hollyhock, Alameda pink. For description and price see Flower Novelties.

HONESTY (Satin Flower; Money Plant) The flat, silvery seed pods are used for winter decoration in the house; pretty and different from anything else. Height 2 feet. Package, $10 \mathrm{c}$.

HUMULUS JAPONICUS (Japanese Hop) A rapid growing, tender climbing annual A rapid growing, tender climbing annual
with dense leaves. Will grow 20 to 30 with dense leaves.
feet. Package, 10c.

HUNNEMANNIA FUMARIAE FOLIA (Busb Eschscboltzia). Known also as the Santa Barbara Poppy. Here is a lemon colored, poppy shaped flower which will bloom all summer. Foliage fine cut and feathery; flowers three inches across. Package, 10c.

HYACINTH BEAN. See Dolichos.

ICE PLANT (Mesembryanthemum crystallinum). The thick leaves seem to be covercd with crystals. Package, 10c.

IMPATIENS SULTANI (Zanzibar Balsam). Much prized for window culture. The foliage is waxy green and witb the semitransparent branches makes a plant in itself attractive. The bright rosy carmine flowers are produced continuously. Package, $10 \mathrm{c}$.

INCARVILLEA DELAVAYI. Flowers are old rose, borne on spikes $11 / 2$ feet tall. The leaves are much cut and are decorative in themselves. Resembles a gloxinia. Package, 10c. 
IPOMOEA. Beautiful annual outdoor climbers of luxuriant growth and fine for covering verandas and arbors, or for screenering verandas and arbors, or for screening unsightly objects. The flowers are like giant morning-glories, to which they are closely related. The seed of several have the outer shell punctured and then soaked in water for eight hours or more feet. Bona-nox (Evening, Glory; Good Night).
Large, fragrant violet blossoms, expanding at night. Package, 10c.

Coccinea (Star Ipomoea). Small scarlet blossoms; vines about 10 feet. Package, $10 \mathrm{c}$.

Grandiflora alba (Moonflower). Large white blossoms, 5 to 6 inches across, which expand at night. The vine grows very rapidly, as much as 50 feet in a season, and is covered at night and in the early morning with a multitude of fragrant white flowers; leaves large. Fine to cover anything in one season. Pack age, $10 \mathrm{c}$; oz., $75 \mathrm{c}$.

Sky-blue Moonflower. Large flowers, 4 inches across, of the softest caerulean blue, shading to white at the edges. Package, 10c

Heavenly Blue. A tall climber with large light blue flowers, yellow throated, and measuring 4 to 5 inches across. Pack age, $10 \mathrm{c}$.

Imperial Japanese. See list under Morning Glory.

Learii. Large, dark blue flowers on a perennial vine. Package, $15 \mathrm{c}$.

Quamoclit. See Cypress Vine.

Setosa (Brazilian Morning Glory). Anuual. The vine has large, overlapping leaves, 8 to 10 inches across, which make a dense shade; useful for covering porches or garden fences. Flowers delicate light reddish purple with pink star in center, in clusters. Package, 10c.

JAPANESE HOP. See Humulus japonicus.

KOCHIA TRICHOPHYLLA (Summer Cypress), Also called "Burning Bush. Annual. Forms dense, oval bushes, 2 to $21 / 2$ fect high, of small feathery light green foliage. As summer advances this green foliage. As summer advances thilly to a fiery red. Package, 10c.

KUDZU VINE (Pueraria Thunbergiana) Hardy perennial. Also called "Jack-andthe-Beanstalk." The first year it will grow 10 feet and the next up to 50 Package, 10c; oz., 60c.

LARKSPUR. There are two classes of the Larkspur which are quite distinct, the annual and the perennial. Both are very fine flowers.

Hardy Annual Varieties. These Larkspurs grow about $11 / 2$ to 2 feet high. They produce a profusion of bloom in a great variety of bright colors; of easiest culture, doing well in any soil.

Double Stock Flowered. Very double annual Larkspur with many branches. It gives a mass of bright color and is fine for cutting all summer. Flowers come all around the spike. Height, $2 \frac{1}{2}$ to 3 feet. Package, 10c.

Dark Blue. Package, 10c.

Lilac. Package, $10 \mathrm{c}$

Lustrous Carmine (Newport Pink). Package, $10 \mathrm{c}$

Shell Pink. Package, 10c.

White. Package, 10c.

Mixed. Package, 10c.

Dwarf Rocket, Mixed. Dwarf plant for bedding; double flowers. Height, 1 foot. Package, 10c.

Azure Fairy. Like Blue Butterfly, only the finest shade of azure-blue. Package, $25 \mathrm{c}$.

Blue Butterfly. A very handsome blue Larkspur with an abundance of flowers on each stalk. Package, $15 \mathrm{c}$.
DELPHINIUMS (Hardy Perennial Varieties). These are taller than the annual sorts and their brilliant flower-spikes arrest your a thention The foliage is attractive and the plants strong and neat in habit. By keeping the plants well watered and the flowers cut a second crop of bloom may be had, an from some a third. The seed is a little difficult to start, so we advise sowing in a box in prepared soil and under a glass.

Belladonna. One of the very prettiest varieties. The flowers are a clear turquoise blue. Package, 20c.

Cardinale. This is the grand Southern Scarlet Larkspur, one of the brightest and finest of California's wild flowers. Height 3 to 5 feet. Package, 20 c.

Elatum Hybridum. Blue, of various shades, with black center; very handsome. Height, 3 to 5 feet. Package, $10 \mathrm{c}$. center. Package, $10 \mathrm{c}$.

Giant Hybrids. A fine strain with colors from pale lavender to deep violet. Grows extra fine, tall stalks. Package, 15c.

Double Hybrids. Specially selected seed, California grown. The majority of the flowers come double. We can highly recommend this new type. Package, 25c

LATHYRUS LATIFOLUS (Perennial or Everlasting Pea). A hardy perennial climber, thriving in any good soil.

Pink Beauty. The ground of the petal is white, edged and shaded with pink. Package, $10 \mathrm{c}$.

Crimson, Package, 10c.

Mixed. Package, 10c.

White. The best variety for cutting, es pecially for florists' use. Package, 10c.

LANTANA, A tender perennial, often becoming shrub-like, 2 to 3 feet high, bearing verbena like clusters of flowers in ing verbena like clusters of flowers in constantly all summer. Package, 10c.

LAVENDER. Perennial. Delightfully fragrant flowers. Package, $10 \mathrm{c}$.

LEPTOSYNE MARITIMA. (See Dahlia.) This is in full flower in winter, with yel low daisy like flowers, 3 inches across. The plant is about 2 feet high and has succulent divided foliage. Get acquainted with this flower. It grows wild on the seacoast. Package, 10c.
Formosum, Bright blue flowers with white

LINARIA HYBRIDS, EXCELSIOR, Flowers are borne in open heads on long, upright stems. The colors are mostly violet and light purple. Package, 10c.

LINUM (Flowering Flax). Hardy annual. Can be sown early outdoors and thrives well in good soil. Package, 10c.

Rubrum (Scarlet Flax). A very showy bedding plant, as the flowers are right on top of the plants. The plant is in bloom for a long time and a bed makes a mass of bright color. Package, 10c; oz., 50c

Perennial Flax. Blue. Package, 10c.

LION'S TAIL (Leonotis). A woody slirub growing 5 feet tall. Blossoms in late summer. Flowers orange. Package, 15c.

LOBELIA. Both annual and perennial and hardy. The annual varieties grow 4 to 6 inches high, are of compact growth and literally covered with small bright flowers. By cutting back the plants during the summer and giving plenty of water, they may be kept in flower until autumn. Used for ribbon work and borders or hanging baskets.

ERINUS Compacta, Celestial (Annual). The finest intense blue for edging. Flowers are borne well on the top of the plant, completely covering it with a mass of intense blue. Package, 15c.

Compacta, Crystal Palace (Annual). Deep blue flowers and dark foliage. A constant bloomer; fine for dark blue borders. Height 6 inches. Package, 10c; $1 / 8 \mathrm{oz}$., $50 \mathrm{c}$

Compacta, Snowball (Annual). A very large flowering pure white Lobelia for edging. A fine companion to Celestial. Package, $10 \mathrm{c}$.

Compacta, Mixed (Annual). Package, 10c.

Gracilis (Annual). Light blue; trailing light green foliage. Excellent for hang ing baskets. Package, 10c.

Light Blue (Annual). A fine bright blue excellent for blue borders; foliage ligh green; plant compact. Package, $10 \mathrm{c} ; 1 / 8$ oz., $50 \mathrm{c}$.

Speciosa (Annual). Deep blue flowers; dark foliage; trailing. Package, 10c.

Cardinalis (Cardinal Flower). (Perennial). The blossoms are produced on tall, showy spikes; brilliant scarlet flowers. showy spikes; brilliant scarlet flowers. sive cultivation. This plant loves a wet, sive cultivation. This plant loves a wet,
boggy place, so water extra well. Package, $15 \mathrm{c}$.

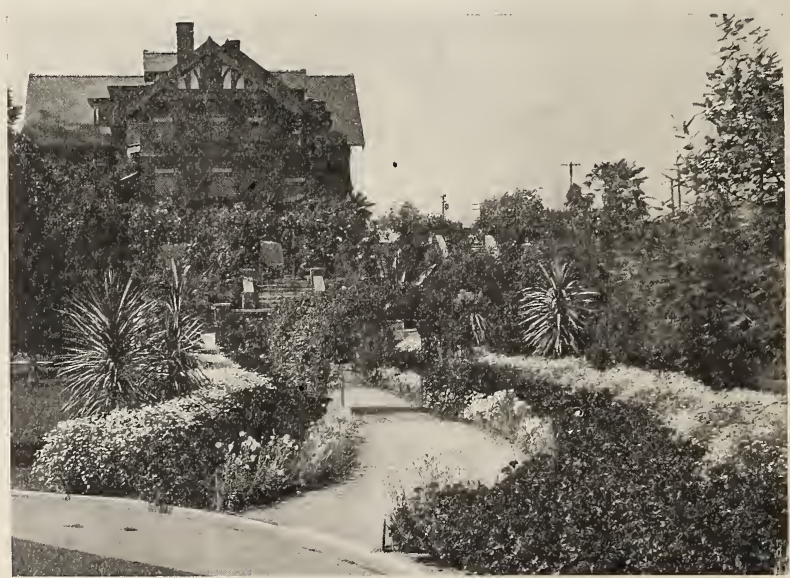

A Border of Annual 
LUPINS. IIardy native California annuals, in great variety, growing from 1 to 3 fee high, and bearing spikes of pea-shaped flowers. Ilartwegii Lupins are much inproved, large flowering annuals. These come into flower early and bear fine spikes 2 fcet tall. Of the easiest culture. spikes 2 fcet tall. Of the easiest culture. Sow in the
inches apart.

Cruikshankii. Dark blue; long racemes. Package, 10c.

Hartwegii Albus. Pure white; fine. Pack. age, $10 \mathrm{c}$.

Hartwegii Albo-Cocconeus. Crimson, tipped white, the whole effect being pink. Package, $10 \mathrm{c}$.

Hartwegii Atroviolaceus. Dark violet. Package, 10c.

Hartwegii, Blue. Clear deep blue. Package, 10c.

Hartwegii Roseus. Pink. Package, 10c.

Hartwegii Coelestinus. Fine azure or very light blue of even color. Thoroughly charming. Package, $10 \mathrm{c}$

Hartwegii Superbus. Rosy purple and white. Package, 10c.

Hybridus Roseus. Long spikes of bright pink flowers. Package, $10 \mathrm{c}$

Nanus. Our little blue and white wild flower. It carpets the fields in late May. Plant by the pound over your grounds. Package, 10c; oz., 35c; 1b., $\$ 3.25$.

Polyphyllus, Mixed. Perennial. This is an extra handsome Lupin. The flower spikes are tall $(11 / 2$ feet $)$ and the leaves are rich bright, glossy green. Attractive at all times. Package, $10 \mathrm{c}$; oz., $40 \mathrm{c}$.

Mixture of all Colors. Package, 10c; oz. $40 \mathrm{c}$.

MARIGOLD. Bedding varieties are very dwarf, and others grow to 3 feet tall; flourishes in all gardens.

Eldorado (African). The best tall variety with large, double blossoms in shades o yellow. Mixed. Package, 10c; $1 / 2$ oz., 40c.

Lemon King (African). Perfectly superb, light yellow flowers $4 \frac{1}{2}$ to 5 inches across. Package, $15 \mathrm{c}$.

Orange (African). A superb rich orange color. Package, $15 \mathrm{c}$.

Golden Ball (French). Extra dwarf, very double. A new compact, bright folden Marigold. Height, 15 inches. Package, $10 \mathrm{c}$.

Gold Edged (French). The flowers ar orange and maroon. Pretty and unusual. Like Golden Ball, is good for bedding: double. Package, 10c.

Dwarf French, or Legion of Honor (French) Single; brown and yellow. Package, $10 \mathrm{c}$

Dwarf French, Mixed (French). Smal flowers. Package, $10 \mathrm{c}$; $1 / 2$ oz., $40 \mathrm{c}$.

Tall French, Mixed (French). A mixture of tall, double varieties in yellow, brown and striped; small flowers. Package, 10c.

Florist's French (French). The beautiful French Marigold used so much for the florist's trade. Package, $10 \mathrm{c}$; $1 / 2$ oz., $50 \mathrm{c}$.

Selected Striped. Tall French type, $21 / 2$ to 3 feet high and just loaded all the season with most striking flowers, 2 inches across. Package, $15 \mathrm{c}$.

MIGNONETTE. A well known favorite iu all old fashioned gardens. Cultivated for its fragrant flowers, which come quickly. Set on compact spikes. Sow in early spring. Height 1 foot.

Allen's Defiance. Long spikes of whitish flowers; compact grower. Package, 10c.

Golden Machet. A compact growing variety, with medium long, thick spikes of yellow flowers. Package, $10 \mathrm{c} ; 1 / 2$ oz., $40 \mathrm{c}$.

Goliath. Wonderful spikes, over 12 inches tall, and equally strong and large. Some thing new and remarkable when wel grown. Package, 10c.

Pure Machet. A compact growing variety, with thick spikes and large sized flowerets. Package, $10 \mathrm{c}$; $1 / 2$ oz., $25 \mathrm{c}$.

Sweet Scented (Roseda odorata). Package, $10 \mathrm{c}$; oz., $40 \mathrm{c}$.

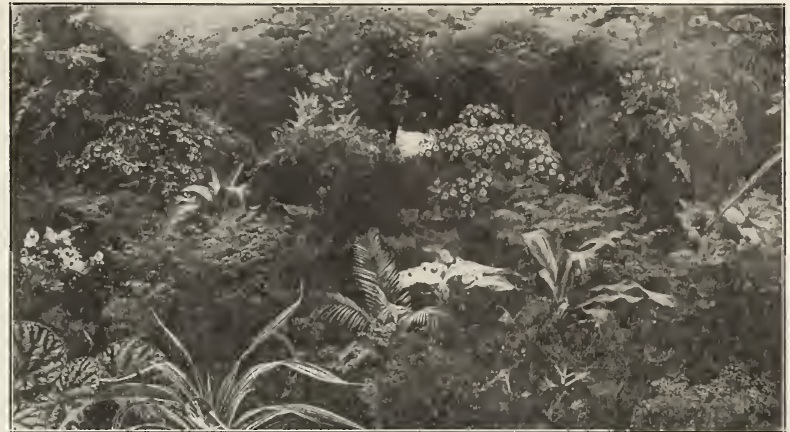

A typicai Southern California grouping of plants

MATRICARIA (Double White Feverfew). Perennial. White, double, button-like flowers; useful for cutting. Package, $10 \mathrm{c}$.

MATTHIOLA BICORNIS (Evening scented Stock). Hardy annual. Purple flowers. Not the handsome Ten Weeks' Stock. Package, $10 \mathrm{c}$.

MINA LOBATA. A fine annual climber which grows very rapidly to a height of 20 to 30 feet in a season. Orange red flowers. Useful for arbor, trellis, etc. Package of 20 seeds, $10 \mathrm{c}$.

MOMORDICA BALSAMINA (Balsam Apple). A climbing annual, growing about 10 feet long. Has graceful and ormamen. tal foliage, yellow flowers and warted, golden yellow fruit, with large carmine red seeds. Balsam Apple and Balsam Pear are climbers which thrive in hot locations and are much planted around locations and are much planted around
Bakersfield. Package, $10 \mathrm{c} ; 1 / 2 \mathrm{oz} ., 60 \mathrm{c}$.

Charantia (Balsam Pear). Same as the Balsam Apple, but fruit is pear shaped and foliage larger. Package, $10 \mathrm{c}$.

MOONFLOWER. See Ipomoea grandiflora alba.

MORNING GLORY (Convolvulus Major). No climber is more No climber is more popular than is the
Horning Glory. For covering trellises or unsightly back fences they and climbing naturtiums are most often planted. Morn ing Glories grow quickly to a vine $15 \mathrm{feet}$ long and bear a great abundance of brilliant, funnel shaped flowers, of various colors, blue predominating. Soak the seed for two hours in warm water to hasten germination; of easy culture. (See also Ipomoea.)

Tall, or Climbing Varieties, Mixed. Pack age, $10 \mathrm{c}$; oz., $25 \mathrm{c}$; 1b., $\$ 2$.

Imperial Japanese. These are by far the handsomest of the Morning Glories, of rigantic size and in colors ranging from snow white to carmine, through every shade of blue and purple. The vine is not quite so vigorous a climber as the above. Package, 10c; oz., 25c.

Dwarf, or Bush Varieties (Convolvulus minor). Useful for beds, edges or hanging baskets. Mixed. Package, 10c.

NEMESIA. Annual. Nemesias come 1 foot high and are a mass of flowers, making them fine for bedding.

Triumph, Mixed. Flowers of light blue, red, yellow, and terra cotta. Compact form. Package, $15 \mathrm{c}$

Compacta, Blue Gem. Clear forget-me-not blue flowers of the most pleasing color in fine, compact heads. Height, 1 foot. This is a beautiful bright blue flower. Package, $20 \mathrm{c}$.
NEMOPHILA (Love Grass). A hardy an nual California wild flower, growing about 6 inches high. Has small cup shaped blossoms about 1 inch in diameter, in white and shades of blue.

Insignis (Baby Blue Eyes). Its flowers are of a most beautiful light blue, shading lighter toward the center. A pretty wild flower. Package, $10 \mathrm{c} ;$ oz., $40 \mathrm{c}$; 1b., $\$ 3.75$

Maculata. White, with each petal spotted violet at tip. Package, $10 \mathrm{c}$.

Mixed. Package, $10 \mathrm{c}$.

NICOTIANA (Flowering Tobacco). A hal hardy annual, growing 3 feet high, with slender, tubular flower. Belongs to the tobacco family. Requires plenty of room in the garden.

Affinis Hybrida. Splendid new hybrids of the popular Affinis. They possess the delicate fragrance of the parent and come in blue, red, rose, white, etc. Package, $10 \mathrm{c}$.

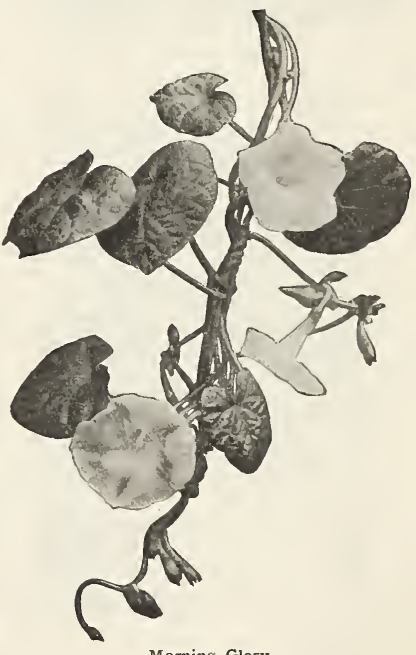

Morning Glory 
NIGELLA (Love-in-a-Mist). A hardy annual, 1 foot high, with finely cut foliage white, with curious seed pods. Of easy culture.

Damascena. Package, 10c.

OENOTHERA (Evening Primrose). Half hardy annual and perennial. Good flowering shade plants are rare, especially in bright colors. The Evening Primroses like half shade best and are yellow in color. The blossom is fully expanded only late in the afternoon. Makes a good plant to grow close to a house.

Annual Varieties, Mixed. Package, 10c.

Lamarckiana. Perennial. A bright yellow Evening Primrose, of great beauty. It is found wild in many parts of California. Height, 3 feet. Package, 10c.

Californica. Our new red budded variety. Flowers are large and bright yellow. Package, 10c.

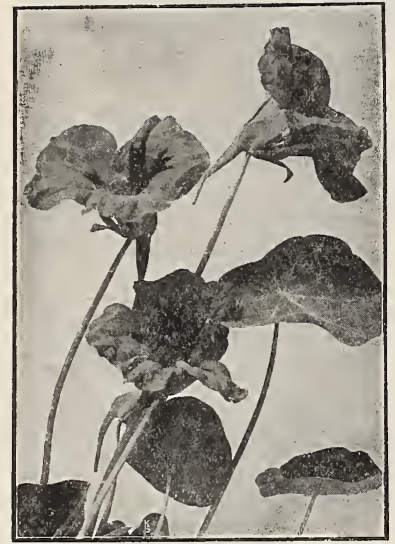

Nasturtiums

NASTURTIUMS. Sow the seed where it is to remain late in the spring and after danger of frost is over. It is seldom necessary to thin the young plants, as they bloom if close together. Nasturtiums prefer dry, rather rocky soil, such as we fer dry, rather rocky soil, such as we usually call "poor" soil, and bear their flowers in such locations in greater pro-
fusion than in a rich garden, where they run too much to leaves. This adds to their value for planting over unsightly places. Hardy annual.

\section{TALL OR CLIMBING VARIETIES}

Of quick growth, covering a wall, hedge or trellis in a short time. The brilliant blossoms almost cover the plant, from top to bottom. On cloudy days when "high fog" is overhead, yellow flowers, such as Nasturtiums, are particularly pleasing. A cheerful tone runs ceptionally bright.

Butterfly. Light yellow, with blotch of deep red on lower petal.

Chameleon. A mixture of changing and inconstant shades, all richly colored and on the same plant.

Fulgens. Extra bright crimson, foliage dark. Gold Garnet. Orange yellow with garnet blotches.

Jupiter. Large, bright, golden yellow.

King of the Blacks. Dark red flowers and dark foliage.

Lucifer. Blossoms deep crimson; leaves brownish green

Moonlight. Immense creamy yellow flowers. Orange. Beautiful orange shade.

Regina. Salmon red, changing to almost cream color.

Rose. Very deep rose pink.

Spitfire. Brilliant flame scarlet.

All packages, $10 \mathrm{c}$; oz., 25c.

Tall Varieties, Mixed. All the named varieties, besides many others in a splendid mixture of all colors and shades. Package, $10 \mathrm{c}$; oz., 20c ; 1/4 lb., 50c; 1b., $\$ 1.50$.

Hybrids of Madame Gunther, Mixed. A splendid mixture of blotched, shaded and variously marked varieties, in glowing tints. Package, $10 \mathrm{c} ; 0 \mathrm{z}$., $25 \mathrm{c} ; 1 / 4 \mathrm{lb}$., $60 \mathrm{c}$; lb., $\$ 2$.

Ivy-Leaf, Mixed. Bright flowers and with leaves like the English Ivy. Package, 15c.

Variegated Queen, or Tall Variegatedleaved, Mixed. Every leaf is variegated with yellow, white and green. This gives a new and very handsome appearance to the plant. The flowers are of all colors and plants come entirely true from seed. Package, $10 \mathrm{c}$; oz., 30c.

\section{DWARF VARIETIES}

The plants form a small, round bush 12 to 16 inches high, which is a mass of bloom al summer. Do not water too much nor sow o rich ground if abundance of bloom is desired. Dwarf Nasturtiums are excellent to line roadways or wherever a tall border is pretty.

Aurora. Yellow, veined carmine. Package, $10 \mathrm{c} ;$ oz., $25 \mathrm{c}$.

Chameleon, Mixed. A dwarf mixture of blotched and inconstant shades on one plant. Package, 10c; oz., 25c; $1 / 4 \mathrm{lb}$., $75 \mathrm{c}$.

Crimson. Package, $10 \mathrm{c}$; oz., $25 \mathrm{c}$; $1 / 4 \mathrm{lb}$,

Golden King. Rich golden yellow. Package, 10c; oz., 25c.

King of Tom Thumbs. Dark scarlet; dark green leaves. Package, $10 \mathrm{c}$; oz., 25c.

King Theodore. Very deep crimson, the darkest of all; nearly black; dark foliage. Package, $10 \mathrm{c}$; oz., $25 \mathrm{c}$.

Rose, or Pink. Fine, distinct color. Package, $10 \mathrm{c}$; oz., $25 \mathrm{c}$.

Rosy Morn. This beautiful new variety of Nasturtium is a remarkably bright, light, cherry scarlet. The plant is compact, with an abundance of flowers wbich are borne well above the leaves. Package, $15 \mathrm{c}$.

Ruby King. Bright red, tinted salmon. Package, 10c; oz., 25c.

Queen of Tom Thumbs. Rosy scarlet; bright green foliage variegated with creamy white. This makes the plant atcreamy white. This makes the plant atPackage, 10c; oz., $25 \mathrm{c}$.

White, or Pearl. Very light lemon-yellow or primrose. Package, $10 \mathrm{c}$; oz., $25 \mathrm{c}$.

Scarlet. Also called "Cloth of Gold." Yellow foliage. Package, $10 \mathrm{c}$; oz., 25c.

Variegated-leaved, Dwarf, Mixed. Handsome bedding; leaves very attractive. Flowers come in all colors and contrast the variegated leaves. Package, 10c; oz., $25 \mathrm{c}$.

Dwarf Varieties, Mixed, A splendid mixture of all the above, besides many other varieties. Package, 10c; oz., 20c ; 1/4 lb., $60 \mathrm{c} ; 1 \mathrm{~b}$., $\$ 1.75$.

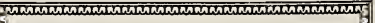 \\ T. F you have friends whom you think will be interested in re- ceiving a copy of this cat- alog, send us their names and addresses; we will be glad to mail them a copy.}

PANSIES. Truly speaking, a perennial, but an annual in California. To obtain the best results the seed should be sown in August, September or early part of October. Prepare a bed in the open ground in the following manner: Dig up the ground and level off the surface. Take some good garden soil and run it throk some good garden soil and run it throug , good rotte also been screened, using about two parts of soil to one manure and one of sand. Spread this out over the surface, press it down, and level off with a board. Sow the seed broadcast, covering it with about an eighth of an inch of the same soil, and again press the surface down with a board. Take a piece of burlap the size of the bed and stretch it out over the of the bed and stretch it out over the ground. around the edge to keep the burlap from
blowing away, and keep it well watered, blowing away, and keep it well watered, has sprouted, take the burlap off and nai it over a wooden framework the same size as the bed. Support this at each end by two small posts and a cross piece, placing this frame about one foot from the ground. After about a week, remove this framework, except during the hottest part of the day. In two or three weeks
it can be discarded entirely. When the plants are large enough to handle, transplant to beds of rich, well prepared soil and cover the surface with a layer of well rotted, sifted manure. Pansies prefer a rather heavy soil with plenty of well rotted manure; this is very essential. Indeed, it is almost impossible to use too Indeed, it is almost impossible to use too much manure on pansies and the richer the soil the larger and more perfect will
be the flowers. Later sowings may be made up to the beginning of February, but they will not do as well as those sown in the fall and the blooming period will be much shorter.

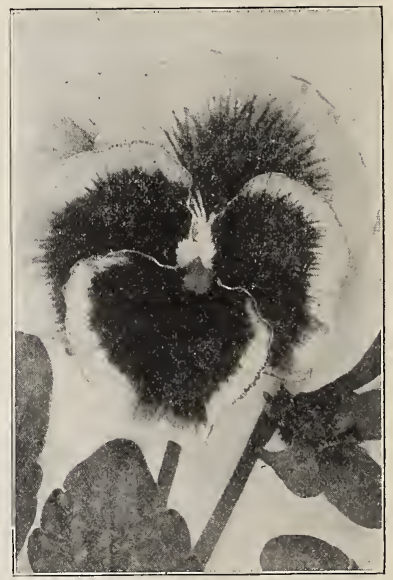

Giant Pansy

Steele's Oregon Giant Pansies. A large flowering variety of all shades and colors that come in that beautiful flower; is disthat come in that beautiful flower; is distinctively American strain; preferred by many California gardeners

GIANT FLOWERED---In separate Colors Packages, $20 \mathrm{c} ; 6$ packages for $\$ 1$

Giant Adonis. Light blue, with dark blue face.

Giant Black. Pure black.

Giant Brown. Deep brown. 


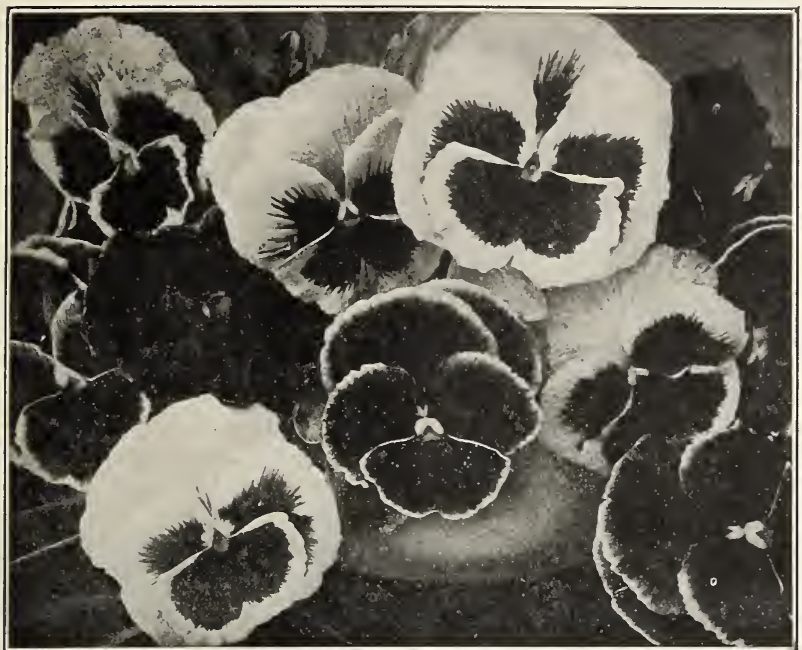

Steel's Oregon Giant Pansies

Giant Ultramarine Blue. Fine even blue. Giant Indigo Blue. A deep indigo color, faced variety.

Giant Lord Beaconsfield. Three lower petals purple, upper two lavender.

Giant Madame Perret. Wine color and white.

Giant Purple. A fine rich shade of purple.

Giant Pure White. Snow white.

Giant White, Three Spotted. Trimardeau type. Three large purple spots.

Giant Pure Yellow. The largest size of this color.

Giant Yellow, Three Spotted. Trimardeau type of yellow-faced pansies.

Giant Masterpiece. These pansies are a most beautiful combination of rich, vel vety, ruffled petal type. Rich dark colorings.

Giant Trimardeau, Mixed. Large flowering type of Pansies, called the French strain. The top petals are larger than the three lower ones and are beautifully marked. Package, $10 \mathrm{c}$.

Giant Odier, or Prize Blotched, Mixed. A large flowered type with round blossoms. The petals are all blotched at the base and distinctly margined on the edge.

Package, 25c.

The following are really good varieties but not as large flowered as the Giants. Very suitable for massing in beds or for borders. In separate colors.

Atropurpurea. Dark maroon.

Azure Blue. Light blue, shaded darker.

Bronze. Deep mahogany.

Coquette de Poissy. Distinct mauve, shad. ing to white on the petals, very pretty shade.

Fairy Queen. Blue, with azure margin.

Fire King. Yellow, with maroon face.

Golden Gem. Pure yellow.

King of the Blacks (Faust). Black.

Lord Beaconsfield. Deep violet blue on lower petals, shading to azure on the upper petals.

Ultramarine Blue. Bright blue.

White (Snow Queen). Pure white.

White, With Black Center.

Bedding Varieties, Mixed.

Packages, $10 \mathrm{c}$; any 6 packages, $50 \mathrm{c}$.
PETUNIAS. Petunias grow with little atten tion or care and in any soil when once started and bloom profusely all spring and summer. The large, double varieties do not produce seed, but the pollen from not produce seed, but the pollen from single and fringed plants, and the seed so produced will make a percentage of double blossoms. The giant flowered types produce large, single, plain edged or fringed edged blossoms, or very thickly double flowers. As Petunia seed is exceedingly. fine, start the plants in a box or flower pot and merely press into the soil after sowing, cover with chopped moss, or sif sowing, cover with chopped moss, or sift a little sand over to cover, and, if pos-
sible, allow the water to soak up from sible, allow the water to soak up from
beneath. The weakest looking plants will develop the handsomest flowers, so save all the plants carefully.

Petunia seed is very fine and very expensive; there is, therefore, but very little seed, almost like dust, in each package. GIANT FLOWERED VARIETIES (All Fertilized by Hand)

Single, Plain Edged, Mixed. Deep throat ed; brilliantly blotched. Package, $25 \mathrm{c}$.

Single, Fringed Edged, Mixed. Deep throat ed, brilliantly blotched. Package, $25 \mathrm{c}$.

Superb Giants. Very strong, vigorous plants with enormous flowers in a great variety of colors, some blotched, some veined and in pretty light shades. If you appreciate fine giant Petunias, try these. Package, 50c.

PENTSTEMON. Pentstemon sends up spike of bright colored and spotted flower somewhat like the foxglove, but in a great variety of carmine shades and colors; decidedly beautiful.

Mixed. Package, 10c.

Excelsior, Mixed. An extra superb strain of this fine flower. Selected for largest size and finest light colors. You will be pleased with this. Package, 25c.

Perennial Pea. See Lathyrus latifolius.

Physalis Franchetii (Chinese Lantern Plant) Has bright yellow or scarlet seed pods. The fruit inside the pod is sometimes made into preserves. Package, 10c.
POPPY. Sow seed in open ground where plants are to remain and thin to 6 to 12 inches. If left thick the plants will be weak and spindling and the blossoms inferior. To avoid getting the seed too thick, it can be mixed with dry sand before sowing.

\section{DOUBLE VARIETIES}

Cardinal. A bright scarlet; fringed; double. Package, $10 \mathrm{c}$

Cardinal Chamois. Salmon pink. Package, $10 \mathrm{c}$.

Double White, Peony-flowered. Straight edges. Package, $10 \mathrm{c}$.

White Fringed, Carnation-flowered. Large ; double ; fringed. Package, $10 \mathrm{c}$.

Double Chinese, Mixed. Unusually fine double flowers, in a wonderful range of colors. Package, $10 \mathrm{c}$; oz., 50c.

\section{SINGLE VARIETIES}

Admiral. Large pure white flower with a broad crimson border. Package, $10 \mathrm{c}$.

Tulip flowered. Intense scarlet, single blossoms. Plant about $21 / 2$ to 3 feet high. The brightest colored of all poppies. Package, $10 \mathrm{c}$; oz., $40 \mathrm{c}$

Shirley. The most beautiful type of poppies, having soft, hairy foliage and an immense variety of single blossoms in white, pink, apricot and shades of red and scarlet. The petals are very dainty and look as if made from crepe paper. Mixed. Package, $10 \mathrm{c}$; oz., $40 \mathrm{c}$.

Umbrosum. Vermillion petals, with black spots on each, similar to Shirley. Package, $10 \mathrm{c}$.

\section{PERENNIAL VARIETIES}

(Bloom First Year from Seed)

Iceland. A graceful, delicate variety, a foot tall, with white, orange and yellow single blossoms, the petals resembling crumpled tissue paper. The plant is low and com pact; excellent for cutting. Sow in the fall where plants are to remain and thin.

Orange. The well known florists' variety. Orange shade. Package, 10c; oz., 75c.

White. Package, 10c.

Yellow. Package, 10c.

Mixed. Package, 10c.

Orientale. The large oriental poppy. A hardy plant, bearing large brilliant crimson flowers, with a black blotch on each petal. Very showy and attractive. Height, $21 / 2$ feet. Package, $10 \mathrm{c}$.

Victoria. A large salmon colored Oriental Poppy. Package, $15 \mathrm{c}$.

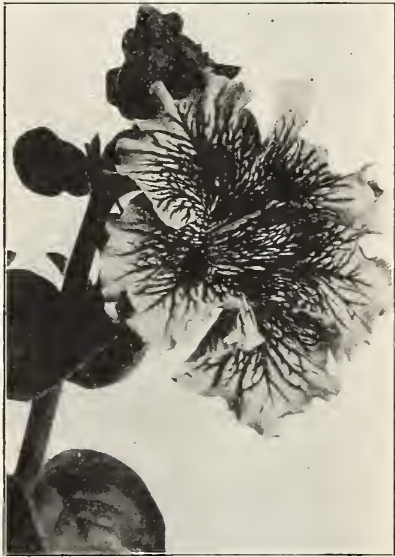

Giant Flowered Petunia 


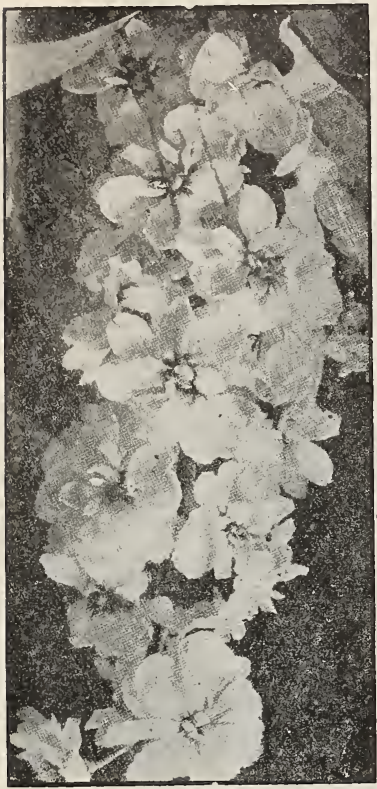

Stocks

PHLOX DRUMMONDII. One of the most satisfactory bedding plants because it blooms over so long a time. A hardy annual, growing from 6 inches to 1 foot annual, growing from 6 inches to 1 foo high, and bearing beautiful and brillianty colored flowers. Sow seed in the fall for
early flowers. Package, 10c; 6 packages for $50 \mathrm{c}$.

Alba. Pure white.

Atropurpurea. Deep purple.

Carnea. Bluish pink or flesh.

Coccinea. Brilliant scarlet.

Large Blood Red.

Rosy Chamois. With yellow center.

Splenderin. Dwarf; bright red, with white

Violet. With white center.

Yellow (Isabellina). Soft primrose.

Starred and Fringed, Mixed. A mixture producing star shaped and pointed blos-

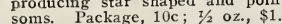

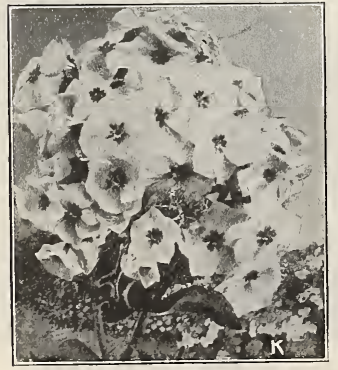

Annual Phlox
PERENNIAL PHLOX, Mixed. Individual flowers similar to the annual variety, but borne in clusters of 30 to 40 flowers on age, $10 \mathrm{c}$.

PORTULACA. Tender creeping annual, 6 to 8 inches high, bearing glossy, cup-shaped blossoms in very brilliant colors. The foliage and stems are thick. The see germinates slowly and should be started under glass or when the weather is hot. These flowers love the sunshine and do best on rather dry ground.

Golden Yellow. Package, 10c.

Scarlet. Package, 10c

Pink. Package, 10c.

White, Package, $10 \mathrm{c}$.

Single Mixed. Package, 10c.

Double Mixed, Large-flowering. Package, $10 \mathrm{c}$.

PRIMROSE. Greenhouse or pot plants, bearing trusses of large, single or double blossoms in bright colors, as well as soft tints. Sow seeds in April or May for winter blooming. Our seed is from the winter blooming.

GIANT SINGLE FRINGED VARIETIES

Alba Magnifica. Pure white. Package, 25c. Rosy Morn. Bluish pink. Package, 25c.

Single Mixed. Package, 25c.

Double Fringed. Saved from the finest blossoms. Package, $50 \mathrm{c}$.

Bright Blue. Package, 25c.

Bright Rose. Package, 25c.

Scarlet. Package, 25c.

\section{HALF HARDY VARIETIES}

Auricula. The primrose of the Alps. Flowers variously colored, mostly yellow; fragrant. Seed selected from selected strain. Package, $15 \mathrm{c}$

Obconica Grandiflora. A lovely free flowering Primula, white tinged with lilac; stems 9 inches high. Package, $25 \mathrm{c}$.

Veris Polyantha. A hardy sort, blooming early in the open gardens. Colors mostly red and yellow. Mixed colors. Package, 10c.

Vulgaris. The true yellow English Primrose. Package, 10c.

Primrose, Evening. See Oenothera.

PYRETHRUM PARTHENIFOLIUM AUREUM (Golden Feather). Small curled leaves of bright golden yellow. Much leaves of bright golden yellow. Much used for edging
$10 \mathrm{c}$; oz., $75 \mathrm{c}$.

Roseum Hybridum. Red petaled flowers radiating from a golden yellow center. Buhach, or insect powder, is made from the dry leaves. Package, 10c.

RHODANTHE (Everlasting Flower). For winter boquets the blossoms should be gathered before fully expanded, and if dried in the shade will retain their brilliancy for years. Rose and white, mixed. Package, 10c.

RICINUS. See Castor-Oil Bean.

ROMNEYA COULTERI (California Tree Poppy). Also well known as the Matilija Poppy. This fine perennial is of a su preme and stately beauty. The flower are large, 4 to 5 inches across, pure white, crinkled like crepe paper, with a fine bunch of yellow stamens, resembling fine bunch of yellow stamens, The seed takes white single peonies. from three to
Package, 10c.

RUDBECKIA BICOLOR SUPERBA (Coneflower). The center of this flower is flower). The center of thew, with vel brown, the petals golden yellow, with velvety brown spots at the base. A free flowering annual 3 feet high; very effec
tive as a cut flower. Package, 10c.

SALPIGLOSSIS. A half hardy annual, growing about 3 feet high, and bearing and colors. Mixed. Package, 10.

Superbissima, Emperor. A splendid giant flowering strain, each stem loaded with these most handsome flowers, and each one richly veined with gold. Package, 10c.
SALVIA (Flowering Sage). A very free flowering late summer plant with flowers of intense scarlet. Start seed indoors early.

Splendens. Bright scarlet flowers. Package, $10 \mathrm{c} ; \mathrm{x} / 4 \mathrm{oz}$., $90 \mathrm{c}$.

Bonfire. A new dwarf scarlet Sage of dense, compact growth. Height 20 to 24 inches. Package, $15 \mathrm{c}$; $1 / 8 \mathrm{oz}, 75 \mathrm{c}$.

Dark Blood Red. A new tall variety with large flower spikes. Much darker and richer in color than other scarlets. Package, $10 \mathrm{c}$.

Patens. Bright blue flowers. Height 2 feet. Package, 25c.

SCABIOSA (Mourning Bride). Also called Sweet Scabious, Old-Maid's Pincushion, etc. Self sown in California. Our mammoth flowering strain of this old-fashioned flower is very beautiful and worthy of a place in every garden. The tall flowers are especially adapted for cutting and massing. These new flowers are double clear to the center, covering the thimbleshaped cone. Height $21 / 2$ to 4 feet.

Mammoth Flowered Double, Mixed (S. maxima). An improved strain with large petals and beautiful colors. Package, 10c.

Caucasica. A hardy perennial variety, with pale blue flowers 4 to 5 inches across, and long stems. One of the handsomest perennial flowers; valuable for cutting. Package, $10 \mathrm{c}$.

Japonica. Hardy perennial. Artistic lavender blue, single flowers. Height $2 \frac{1 / 2}{2}$ feet. Package, 10c.

\section{TALL DOUBLE SORTS}

Azure Fairy. Light blue. Package, 10c.

Black Purple. Package, 10c.

Snowball. Pure white. Package, 10c.

Rose Pink. Package, 10c.

Red. Package, 10c.

SCHIZANTHUS. Hardy annuals, growing $11 / 2$ to 2 feet high, and covered with bright, showy, butterfly-like blossoms.

Wisetonensis. Remarkably free flowering and presents a beautiful appearance with its myriads of blooms, the ground color of which is white, dotted with delicate rose. A very shy seeder. Make several plantings as the plants come into bloom quickly and are a mass of color. Pkg., $15 \mathrm{c}$.

Large Flowering Mixed. Package, 10c.

STATICE, RUSSIAN. Long rat-tail spikes of small pink flowers. Very effective and are everlasting. Package, 20c.

Sinuata (Sea Lavender). Annual. Everlasting flower much used by florists for winter boquets. Each floweret is small, but in a boquet becomes a mass of blue, yellow or white. Height 2 to 3 feet. Yellow, blue and white, each, per package, $10 \mathrm{c}$.

SOLANUM CAPSICASTRUM (Jerusalem Cherry). For house or garden culture. The flowers are followed by small, brightly colored fruit or berries, which almost completely cover the plant. Package, $10 \mathrm{c}$

SEAFORTHIANUM. Tender perennial. Blue climber. Package, 15c.

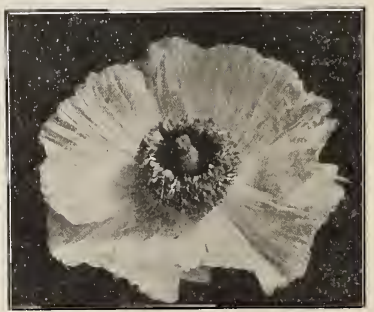

Matilija Poppy 
SNAPDRAGON. Snapdragons are biennial and may be sown in the fall or in the spring, outcloors where they are to remain, or they may be sow'n in boxes and transplanted. They are fine cut flowers, easily raised. You cannot afford to leave them out of your garden. They flower them out of your garden.
very freely for a long time.

TALL, LARGE FLOWERING TYPE 24 to 30 inches high.

Blood Red. Dark crimson maroon, with dark foliage. Package, $10 \mathrm{c}$

Crescia. Scarlet. Package, 10c.

Katharine Morse. Color golden rose, calys and stem dull gray-green, a good florist variety. Package, $10 \mathrm{c}$.

Lilac Queen. Beautiful soft lilac. Package, $10 \mathrm{c}$.

Old Rose. Package, 10c.

Princess Patricia. Beautiful flesh pink. Package, 10c.

Queen Victoria. Pure white. Package, 10c. Vermillion Brilliant. Fine orange scarlet. Package, $10 \mathrm{c}$.

Yellow. Large; golden yellow. Pkg., 10c. Giant Striped, Mixed. Finest Scotch strain, unsurpassed for size, beauty, and variety of coloring. Package, $10 \mathrm{c}$.

Giant Flowered, Mixed. Package, $10 \mathrm{c}$; $1 / 4$ oz., 40c.

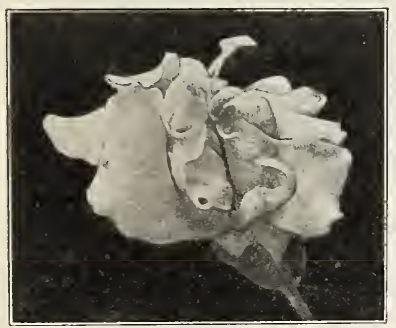

Snapdragon

INTERMEDIATE TYPE

15 to 24 inches high, for bedding.

Black Prince. An even wine maroon color. Package, 10c.

Bull Queen. Lovely shade of rose with shaded orange lip. Package, 10c.

Crimson Queen. Very dark, velvety red with dark tube. Package, 10c.

Diana. Beautiful clear, bright pink, with white throat. Package, $10 \mathrm{c}$.

Fascination. Deep flesh pink. Package, 10c

Golden Queen. Large ; rich yellow. Pack age, $10 \mathrm{c}$.

Grenadier. Novelty. Orange scarlet face with yellow lip, white tube. Whole effect is bright flame, deep yellow and white. Package, 10c.

Mauve Beauty. An entirely new and rare color. A lovely shade of pale, clear mauve. Package, 10c.

Vesuvius. Orange or flame color. Pkg., 10c

White Beauty. The finest white. Pkg., 10c.

Grandiflora, Mixed. Pkg., 10c; 1/4 oz., 40c

SMILAX. A climbing perennial with beau tiful, bright green glossy leaves, much esteemed for its long, delicate sprays of foliage. Package, 10c; oz., $75 \mathrm{c}$.

STEVIA SERRATA, A tender perennial, 11/2 feet high, bearing clusters of small, white, fragrant blossoms. Suitable for summer or winter blooming and for pot culture or open air. Package, 10c.

STOKESIA CYANEA (Cornflower Aster). A hardy perennial, 2 feet high, and bearing large blue flowers on long stems. Blooms freely all summer and fall, and is of easy culture, but is hard to start from of easy culture, but
seed. Package, 10c.
SUNFLOWER (Helianthus). Hardy annuals, growing from 3 to 6 feet high. Of the easiest culture and suitable for a stately row or background. Plant when ground is well warmed, in light or sandy soil.

Chrysanthemum Flowered. Large, densely double, bright golden yellow flowers. The plant branches and affords fine, long, stout stems for cutting. This is the best varicty in existence. Height 6 to 8 feet. Package, $10 \mathrm{c}$; oz., $35 \mathrm{c}$.

Cucumerifolius, Perkeo (Minature Sunflower). The Cucumerifolius Sunflowers are small, both in flower and plant, and are often called "Cut and Come Again" Sunflowers. Perkeo is only 2 feet tall, but is covered with small ( 3 inch) golden yellow flowers with a dark eye. Package, $10 \mathrm{c}$.

Cucumerifolius, Stella. Is considerably talle than Perkeo and has larger single flowers ( 6 inches across) yellow with black center. Package, $10 \mathrm{c} ; 1 / 2$ oz., $50 \mathrm{c}$.

Red Sunflower. Some are solid red, of a deep maroon shade; others are red with petals gold tipped, and a variety of other pleasing combinations of red and gold. Package, $10 \mathrm{c}$.

STOCKS (Gilliflower). A favorite annual succeeding best in California during the winter seasou. Largely grown for cut flowers, lasting a long time in water. Very effective for planting in beds or borders. To obtain the best results the seed should be sown in August, September, or early part of October, in seed boxes of rather light soil, and afterwards trans. rather light soil, and afterwards transplanting stocks care should be taken to planting stocks care should be taken to
save the small or weak-growing plants, as these generally produce double flowers, while the strong, robust growing seedlings often come single. The seed we offer is obtained direct from one of the best specialists in Europe and can be relied upon to produce a large percentage of double flowers.

Dwarf Large Flowering Ten Weeks. Our strain of these has great rosettes set closely together so that the entire plant is hidden in the mass of bloom. Plants 12 to 15 inches tall; early; the best for bed ding effects or edges. Ours is a selected strain.

Blood Red. Package, $15 \mathrm{c}$

Light Blue. Package, $15 \mathrm{c}$

White. Package, $15 \mathrm{c}$.

Canary Yellow. Package, 15c.

Pink, Package, 15c.

Purple. Package, $15 \mathrm{c}$

Mixed. Package, 10c.

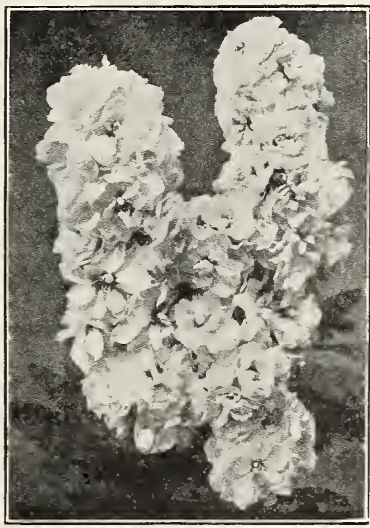

Giant Stocks
Giant Perfection. An early or Ten Weeks' Stock, with tall spikes of large very double flowers. This Stock branclies into a pyramidal form and is 2 feet tall. Mixed. Package, 20c.

PERPETUAL STOCKS (CUT AND COME AGAIN)

Early, large flowering type.

Brilliant. Deep rose crimson, a very fine color. Package, $15 \mathrm{c}$

Creole. A light yellow, slightly tinted flesh. Package, $15 \mathrm{c}$.

Dark Blue. Package, 15c.

Rose Pink. Package, $15 \mathrm{c}$

Light Blue. Package, 15

Pure White. A pure white, double stock; largely used by florists. Package, $15 \mathrm{c}$.

Dresden, Mixed. All colors. Package, 15c

t/8 oz, 50c.

STOCKS (FOR SUMMER AND WINTER)

Tall Stocks, nicely branching, with large double flowers, not tightly clustered but borne along the entire stem. Sow in July and August and they will flower all winter. There are many new varieties in this class. May be treated as summer stocks, for they
quite as early from seed. Height 2 feet.

Almond Blossom. Bluish pink, shaded deeper. Package, $15 \mathrm{c}$.

Beauty of Nice. A beautiful flesh pink. Package, $15 \mathrm{c}$.

Crimson King. Splendid crimson color Package, $15 \mathrm{c}$

Mont Blanc. Improved pure white. Package, $15 \mathrm{c}$.

Monte Carlo. A good yellow. Package, 15c.

Purple. Purple or violet color. Pkg., 15c

Queen Alexandra. Light.. lilac, shading deeper at bottom of petals and lighter on the new flowers. Package, $15 \mathrm{c}$.

Mixed. Package, $15 \mathrm{c} ; 1 / 4$ oz., $85 \mathrm{c}$

\section{WINTER STOCKS}

Handsome, late flowering sorts.

White Lady. Our new pure white winter Stock. Grows about 20 inches high, has large branches bearing lustrous, snow:y white, double flowers, most freely. The grandest white stock. Package, 20c

SWEET ROCKET (Hesperis). A hardy perennial, growing to 3 feet high. This old fashioned, fragrant flower is of the easiest culture, and bears clusters of white and purple blossoms. Mixed. Package, 10c.

SWEET SULTAN. .-See Centaurea moschata SWEET WILLIAM (Dianthus Barbatus). A beautiful sweet scented, old fashioned perennial. Grows 1 to 2 feet high and bear its flowers in clusters at the end of a stif stem. The individual flowerets are hand somely colored and marked. It makes a beautiful bedding plant, and is of easy culture. Hardy perennial.

Crimson Bedder. Beautiful crimson variety especially suitable for massing in beds or borders. Package, 10c

Pink Beauty. A truly wonderful pink. Package, $10 \mathrm{c}$

Scarlet Beauty. Intense scarlet. These new sorts should be planted by everyone. Package, 10c.

Single Varieties, Mixed. More attractive than the double. Package, 10c. $1 / 4 \mathrm{oz}$. $40 \mathrm{c}$.

Double Varieties, Mixed. Package, 10c.

THUNBERGIA (Black-eyed Susan). A hardy annual climber, growing about 4 feet long. Blossoms are buff, orange or white with dark centers. Mixed. Package, 10c.

TRANSVAAL DAISY (Gerbera Jamesonii). Tender perennial. Intense vermillion. Flowers, 4 inches across, on tall stems $11 / 2$ feet high. Sow seed upright, stem end in, in a box of peat and loam. Two plants from a package is a fair average. Do not over-water; very beautiful. Package, 25 seeds, $25 \mathrm{c}$.

VIOLET, SINGLE BLUE (Viola adorata) Although these flowers do best propagated from cuttings, they grow readily from seed, and have a very fragrant blos. som. Package, 10c. 
VINCA (Madagascar Periwinkle). Useful for bedding in summer and for the greenhouse in winter. Blooms freely the first year from seed. Flowers rose, crimson year from seed. Find white. (The trailing blue, Vinca or Myrtle propagates from plants only.) Myrtle propagates from
Mixed. Package, 10c.

VIRGINIAN STOCK, Red and White. Mixed. Package, 10c.

VERBENAS, GIANT STRAIN. A hal hardy perennial of easy culture. While it grows readily from division of the root or from cutting, it does best from seed. Use extra care in starting, as seed is rather difficult to start well. Seed may be soaked in warm water to hasten germination.

Mammoth Auricula Flowered. Fine large flowers in big heads. Each floweret has clearly defined eye. Package, $10 \mathrm{c}$.

Pink Shades. Mammoth strains of rose shades. Package, 10c.

Pure White. Mammoth strain. Package, $10 \mathrm{c}$.

Purple and Blue Shades. Mammoth strains. Package, $10 \mathrm{c}$

Scarlet Defiance. Large, brilliant scarlet. Package, 10c.

Striped Varieties. Mixed. Package, 10c.

Hybrida Gigantea, New giant Auricula flowered Verbena in new and beautiful shades. Package, 15c.

Mammoth Flowered, Mixed. Package, $10 \mathrm{c}$

VIOLAS (Tufted Pansies). These have smaller flowers than the regular pansies, but bear them so profusely that they are preferred for bedding effects where color only is wanted. Height 6 inches. Purple, yellow, white; mixed, all varieties. Package, 10c.

ZINNIA. One of our leading specialties. Our strains of Giant Picotee, Victory and Dahlia Flowered have proven a grand success and we offer this year again improved types of these valuable novelties.

New Dahlia Flowered. This is a new and distinct race of Zinnia, which will greatly increase the popularity of this flower. The plants of this new race are very sturdy and produce many flowers with stout stems. In formation the broad petals are closely inbricated, some closely inbricated, sometimes seeming almost to be pinned one upon the other. The flowers in full bloom often measure four inches in depth and six to eigh inches in diameter. In general appearance the flowers compare favorably with the Show Dahlias. The flowering season lasts from July until the frost comes.

We offer this in Mixture; a wide range of color, including Golden Yellow, Burnt Orange, Old Rose, Mauve, Cerise and an endless range of pleasing shades of pink from Rose Pink to Tyrian Rose and many bi-color shades. describable only with the aid of a color chart. $25 \mathrm{c}$ per package.

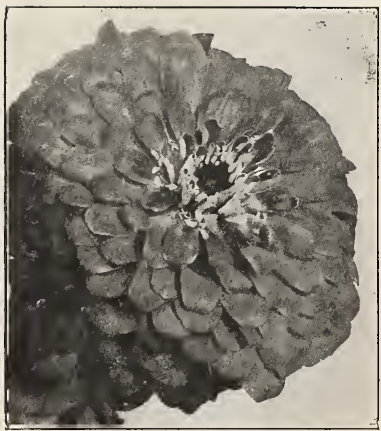

New Giant Zinnia

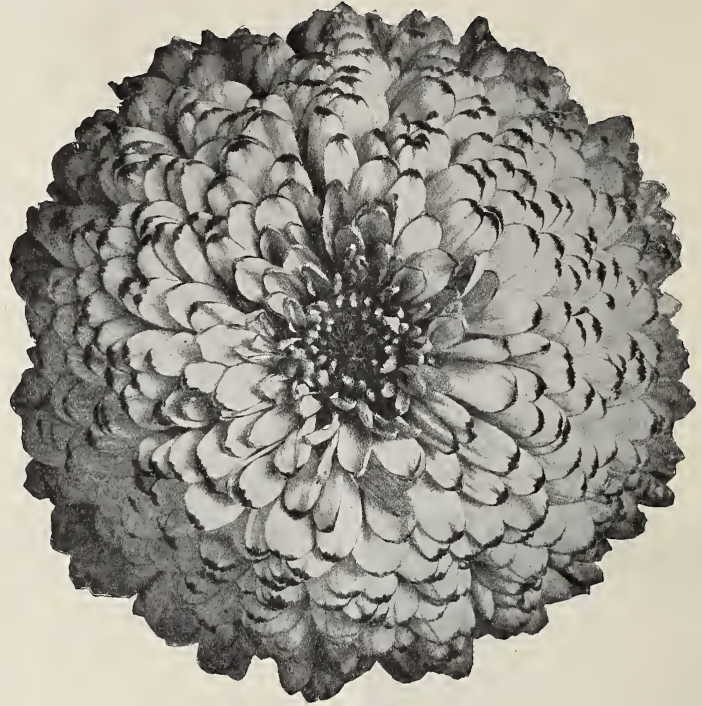

Giant Picotee Zinnia

GIANT PICOTEE TYPE. Like the Picotee Sweet Pea, this very attractive novelty has taken well among the flower fanciers and we are pleased to advise the Picotee markings are more pronounced this season with a larger range of colors, including many shades of Crimson, Scarlet, White and Pink, with well defined Gold Picotee markings on slightly fringed petals. Pkg. 25c.

Victory. This is a quilled or canaled type of Giant Zinnia quite similar to the Novelty Achievement, but with larger flowers and a different range of color. The petals are peculiarly quilled and twisted with pin wheel effect in the center. The outsides of the petals are of a coppery golden color and on the underside various shade of Rose and Lilac, which when the petals twist, reflect pleasing autumn colors. Package, 25c.

New Giant or Colossal Buttercup. This new and pleasing color is a valuable addition of the collection of Giants, coming positively true to type and color this season. Buttercup is identical with the other Giant Zinnias, color, pleasing deep prim rose which holds its color in bright California sunshine. Takes well and will supersede cream, canary and sulphur yellow. Package, 25c

WALLFLOWER, Half hardy perennial, blooming the first year from seed. Height 1 to 2 feet.

Golden Monarch. Large single, pure yellow flowers. Gives an exceptionally bright color effect. Package, 10c.

Vulcan. Giant, bright crimson, single va riety. A fine companion to Golden Monarch in bedding effects. Package, 10c.

Fine Single, Mixed. Package, $10 \mathrm{c}$

Double Mixed. Package, $15 \mathrm{c}$.
WISTERIA, Chinese Flowering, Tall Blue. Climber. Package, $15 \mathrm{c}$.

XERANTHEMUM (Everlasting Flower). Annual. Flowers white, purple or yellow. Height 2 feet. Double mixed. Pkg., $10 \mathrm{c}$.

\section{CALIFORNIA WILD FLOWER COLLECTION}

The description of these beautiful wild flowers will be found in the Flower Seeds under their alphabetical order.

Baby Blue Eyes. See Nemophila in signis.

Blazing Star. See Bartonia aurea.

Blue Gilia. See Gilia achilleaefolia.

California Poppy. See Eschscholtzia californica.

Clarkia. See Clarkia elegans.

Evening Primrose. See Oenothera.

Farewell to Spring. See Godetia amoena.

Lupin. See Lupin.

Matilija Poppy. See Romneya Coulteri.

Sand Verbena. See Abronio umbellata. Sea Dahlia. See Leptosyne maritima.

One package of each of the above included in this collection. All postpaid for $\$ 1.00$. 


\section{Winsel-Gibbs Selected Sweet Peas}

\section{The Ideal Flower for Garden and Cutting}

Several hundred varieties of Sweet Peas are offered by the different growers and seedmen in the United States and Europe. Every year we try out a number of these varieties and also keep a record of the experiment made by the main growers of these beautiful flowers. From the result of these experinients, our list is carefully revised each year, with the view of keeping on this list only the most deserving varieties. In looking over our list, you will notice that some of the older varieties have been dropped off to make room for more improved and newer ones.

Sweet Peas are divided into three classes. First, the Early or Christmas varieties, which are generally planted in September or the first of October for Christmas or New Year's flowers. Next are the Orchid flowering or waved varieties, which comprise the Spencer and Unwin Sweet Peas. The Spencer are considered the best of the two on aceount of the flowers being larger. The third elass is the Standard or Grandiflora type, whieh eonsists of the varieties generally used by florists for eut flowers. They are strong growers and free bloomers, and of these we have only the very best in the list that follows. The Speneer, Unwin and Standard Sweet Peas are sown as early as possible in the spring, and will produee flowers up to the time that the Christmas varieties begin to bloom in the fall.

\section{SWEET PEA CULTURE}

We find that our customers frequently: have trouble in raising Sweet Peas, and especially in making the seed germinate. We find that the main cause of this failure is due to the fact that the seed has been sown too deep.

For Christmas flowering, the seed is sown in August or September, and for early spring blooming, the seed is sown in November, and it is in sowing these last ones that the greatest trouble is experienced. About November the ground begins to cool off, and if the seed is sown too deep they will not come through, especially the white flowering varieties.

Sweet Peas are generally sown in rows, furrows or trenches as they might be called. These trenches should be four inches deep, but this does not mean that the seed should be covered with four inches of soil at first. After digging this four-inch trench, place the seed in the bottom and then rake down from the sides of the trench just enough soil to cover them, but this should never be more than half an inch. Never sprinkle Sweet Peas, but run the water right into this trench over but run the water right into this trench over
them. When they are up two or three inches, begin to hill them in a little until the trench is filled and level with the surface of the ground. Then a little irrigating ditch is made on each side of the seedlings. Once a week will be sufficient irrigation in ordinary soil, and then the day after irrigation, or perhaps and then the day after irrigation, or perhaps
the second day after, or just as soon as the the second day after, or just as soon as the
earth can be easily worked, these ditches are filled in, and the ground in them thoroughly cultivated and pulverized with a cultivator. The ditches are dug anew for each irrigation, and are filled in and cultivated each time in the same manner. It must be remembered that Sweet Peas must not be sprinkled as this and the heavy fogs is the cause of mildew and the heavy fogs is the cause of mildew
which is so often found on Sweet Peas. Both bone meal and sheep manure are great fertilizers for Sweet Peas. Do not use fresh manure by any means.

SPENCER SWEET PEAS. A grand new class of Sweet Peas, having large, round, open flowers of extraordinary size, of ten 2 inches across, with wavy standard and 2 inches across, with wavy standard and
wide spreading wings, a large number of the flowers coming four on a stem.

Apple Blossom Spencer. Rose and blush White. Package, $10 \mathrm{c}$; oz., 30c.

Asta Ohn Spencer. Lavender shaded with mauve. Package, $10 \mathrm{c}$; oz., 30c.

Ccuntess Spencer. Clear pink, deepening some what towards the edge. A very large flowered variety. Package, $10 \mathrm{c} ; 0 \mathrm{z} ., 25 \mathrm{c}$.

Dobbies Cream. Cream color. Package, $10 \mathrm{c}$; oz., 30c.

Elfreda Pearson. Blush pink, deepening towards the edges. Package, $10 \mathrm{c}$; oz., $30 \mathrm{c}$.

Florence Morse Spencer. Delicate blush, with pink margin. Package, $10 \mathrm{c}$; oz., $30 \mathrm{c}$.

George Herbert. Very large, rose crimson suffused with magenta. Package, 10c; oz., 30c.

Helen Lewis. Orange salmon. Package, $10 \mathrm{c}$; oz., 30c.

King Edward Spencer. A magnificent flower, bright crimson scarlet. Said to be the largest Sweet Pea grown. Package, $10 \mathrm{c} ;$ oz., 30c.

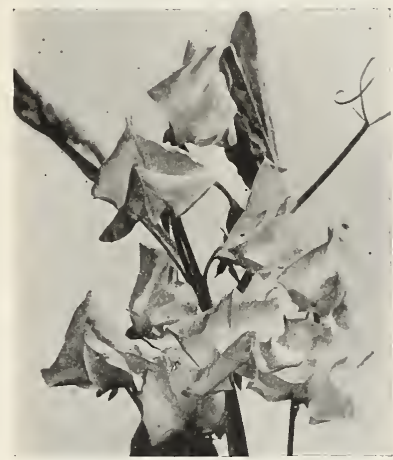

Songbird. A beautiful light pink, about the color of Florence Morse Spencer. Package, $25 \mathrm{c}$; oz., 60c.

Spring Maid. Light flesh pink. Produces a great wealth of blossoms on long stems, generally in fours. Package, $25 \mathrm{c} ; 0 \mathrm{z}, 60 \mathrm{c}$.

Early Asta Ohn. Lavender. Package, 25c; oz., $60 \mathrm{c}$.

Apricot Orchid. Buff pink. Package, 25c ; oz., 60c.

Hercules. Very large, rosy pink. Package, $25 \mathrm{c} ; \mathrm{oz}$., $60 \mathrm{c}$.

Red Orchid. Deep red. Package, 25c; oz., $60 \mathrm{c}$.

White Orchid. Pure white. Package, 25c; oz., 60c.

Yarrawa. Bright rose pink with light wings. Package, 25c; oz., 60c.

Early Choice Mixed. Package, 25c; oz., $75 \mathrm{c}$.

LARGE FLOWERED SWEET PEAS. A fine assortment of large flowering Sweet Peas in a variety of color that will please the most exacting. Per package, 10c; dozen packages, $50 \mathrm{c}$; oz., $20 \mathrm{c}$; $1 / 4 \mathrm{lb} ., 35 \mathrm{c}$; 1b., $\$ 1.25$.

Black Knight. Deep maroon.

Bolton's Pink. Brilliant pink with tint of salmon.

Dorothy Eckford. Pure white, large flowers. Helen Pierce. White ground, marbled blue. Hon. Mrs. E. Kenyon. Deep primrose yellow.

White. New, very large, the fines
white variety. Package, $10 \mathrm{c} ; \mathrm{oz}, 35 \mathrm{c}$

Margaret Atlee. Immense flowers, cream ground color overlaid with salmon pink. Package, $10 \mathrm{c}$; oz., $35 \mathrm{c}$.

Mirian Beaver. Salmon pink on cream ground. Package, $10 \mathrm{c}$; oz., 35c.

Nubian. Deep maroou. Package, 10c ; oz. $35 \mathrm{c}$.

Old Rose. Beautiful old rose. Package, $10 \mathrm{c}$; oz., $40 \mathrm{c}$

Primrose Spencer. Primrose. Package, $10 \mathrm{c} ; \mathrm{oz}, 35 \mathrm{c}$

Vermillion Brilliant. Scarlet. Package, 10c oz., 35c.

Wedgewood. Light blue, extra fine. Package, $10 \mathrm{c}$; oz., $35 \mathrm{c}$.

White Spencer. Flowers of immense, size, pure white. Package, $10 \mathrm{c}$; oz., 30c.

Spencer Mixed. Package, $10 \mathrm{c} ; 02 ., 25 \mathrm{c}$; $1 / 4$ lb., $75 \mathrm{c}$.

NEW WINTER FLOWERING OR LONG SEASON SPENCER SWEET PEAS. A new race of Sweet Pea, having the large waved flowers of the Spencer type, but flowering fully two months earlier, they flowering fully two months earlier, they also continue in flower for a much longer
period. For Christmas flowering sow in September, later sowing may be made up until March.

Fordhook Pink. Pink suffused with lavender. A distinct shade, particularly pleasing under artificial light. Package, 25c ; ing $60 \mathrm{c}$.

Melody. A deeper shade of pink than Songbird Flowers borne on long stems, generally four large, wavy blossoms to each stem. Package, 25c; oz., 60c.
Janet Scott. Deep salmon pink, very large. King Edward VII. Bright crimson.

Lady Grisel Hamilton. Delicate silvery lavender.

Lord Nelson. Rich indigo blue, wings purple.

Prima Donna. Pure pink.

Prince of Wales. Bright rose, very large. Large Flowered Mixed. Package, $10 \mathrm{c}$; oz., $20 \mathrm{c} ; 1 / 4$ lb., 30c ; 1b., $\$ 1.00$.

\section{CHRISTMAS FLOWERING SWEET PEAS} The Christmas or forcing varieties of Sweet Peas are quite distinct from the other kinds, being an extra early race, flowering early in winter at a time when the other kinds will not bloom. By sow. ing them late in summer they can be had in full bloom at Christmas time.

Christmas Pink. Package, $10 \mathrm{c}$; oz., $30 \mathrm{c}$.

Earliest Sunbeams. Primrose. Package, $10 \mathrm{c}$; oz., 30c.

Florence Denzer. Pure white. Package, $10 \mathrm{c}$; oz., $30 \mathrm{c}$.

Meteor. Crimson. Package, $10 \mathrm{c}$; oz., 30c.

Mrs. Alex. Wallace. Lavender. Package, $10 \mathrm{c}$; oz., 30c.

Mrs. C. H. Totty. Light lavender, Package, $10 \mathrm{c}$; oz., 30c.

Mrs. J. F. Dolansky. Clear pink. Package, $10 \mathrm{c} ;$ oz., 30c.

Mrs. Wm. Simms. Salmon buff. Package, $10 \mathrm{c}$; oz., $30 \mathrm{c}$.

Christmas Mixed. Package, 10c; oz., 30c. 


\section{Winsel-Gibbs Re-selected Bulbs for Fall Planting}

The best procurable

The bulbs we offer in this list are grown for us by one of the most reliable bulb growers in the Netherlands. We pay these growers a high price for these bulbs in order to have first choice from their fields. If in some instances the prices seem a trifle high, we invite you to compare our bulbs with those afforded by other firms. We are satisfied that there are no larger bulbs imported into the United States than those we offer. We can assure our customers that they will give good results as we have been acquainted with these growers for more than twenty-five years. Last season we received many favorable comments from our customers as to the results obtained from our bulbs, and especially on the Ranunculus and the Giant Emperor Narcissus.

Our books show that we have as customers some of the most critical buyers in this part of the state.

CROCUS. The earliest of all flowering bulbs. Can be grown in almost any kind of garden soil. Plant during November
and December, 3 or 4 inches deep, and and December, 3 or 4 inches deep,
about 4 inches apart. 60 c per dozen.

HYACINTHS. Plant beginning the first of October and continue during November and December. Hyacinths are unsurpassed for beauty, variety and coloring of the flowers, beauty, variety and coloring of the flowers,
of easy culture. Plant the bulbs in pots of easy culture. Plant the bulbs in pots
filled with rich sandy soil ; bury them in filled with rich sandy soil; bury them in
the ground to a depth of 12 inches on the north side of the building or in a cellar for about one month; then bring to gradually and rather carefully. If for bedding in the open ground remove the bulbs from the pots, taking care not to disturb the roots. This is done by turning the pots wrong side is done by turning the pots wrong slides out of the pot. For open ground slides out of the pot. For open ground
blooming, Hyacinths may be planted right out in the open beds, cover the ground with white sand or boards to prevent the bulbs from making their flower stalks before they are well rooted. It is not necessary to remove the bulbs and store them a way when they are through.

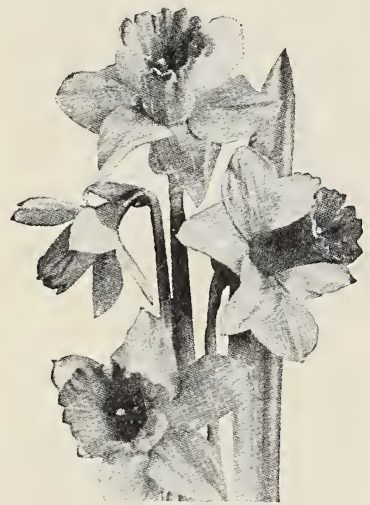

Daffodil

HYACINTHS. Single, separate colors, $15 \mathrm{c}$ each; $\$ 1.50$ per dozen,

Double. Separate colors. Pink, red, white, blue or yellow. $15 \mathrm{c}$ each; $\$ 1.50$ per dozen. Mixed Colors. All shades and colors. Single only. $10 \mathrm{c}$ each; $\$ 1.00$ per dozen.

Every season numbers of customers, having no experience with Hyacinths, Tulips, ing no expend Anemones, come to us, after putting in their bulbs, asking if these bulbs putting in their bulbs, asking that they take are going to grow. The fact that they take
a long time to show any signs of growth a long time to show any signs of growth is a good indication. It is necessary for them to make a root system before throwing up the flower stems, which takes from two to three months.

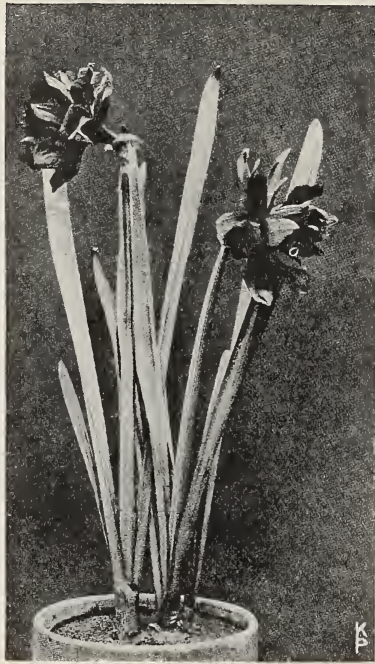

Silver Pboenix Narcissus

NARCISSUS. One of the hardiest and earliest growing of all bulbs. Can be planted from November to February in any good soil; they need to be dug every two years in order to divide the bulbs and give the ground a thorough spading and fertilizing.

Double Von Sion. The big, double golden yellow daffodil. Extra select strong bulbs. $10 \mathrm{c}$ each; $75 \mathrm{c}$ per dozen.

Double White Narcissus, Silver Pboenix or Double White Daffodil. Very fragrant, resembling a Gardenia blossom. This variety sembling a Gardenia blossom. This variety is recommended for

Emperor. One of the largest and most beautiful of all Narcissus. We have made a specialty of this variety for the last ten years and have imported the largest bulbs ever seen in Los Angeles. We furnish only three-year-old, double nosed bulbs. Produces an abundance of flowers with a deep full yellow trumpet. Price, 10c each; $\$ 1.00$ per dozen.

CHINESE NARCISSUS. The genuine Chinese Sacred Lily. Imported and offered for sale in the original Chinese baskets. Immense bulbs, surrounded by a number of small bulblets. Each, 15c.
TULIPS. Plant in the open ground during November and December. Give same care as Iyacinths. Can be grown in pots, which should be plunged in a cool place to a depth of 12 inches, until the bulbs are well rooted.

To grow tulips successfully, it is necessary to have a rich sandy soil, mixed thoroughly with sheep manure or old cow manure. The soil should be well drained, and kept well watered during the coming season. If tulips are planted in heavy soil, sand should be used to pack around the bulbs, and at least an inch of it to be spread on top of the ground. This has a tendency to keep the ground cold and under these conditions tulips will produce large flowers on long stems, especially if the bulbs are planted on the shady side of the house or under trees.

Singie, Large Flowering. All colors, mixed. 10c each; $\$ 1.00$ dozen.

Double Flowering. All colors, mixed. $10 \mathrm{c}$ each; $\$ 1.00$ per dozen.

Single, in Separate Colors. $10 \mathrm{c}$ each; $\$ 1.00$ perd ozen.

Among the single tulips we recommend the Gesneriana with its beautiful large red flowers. They are about the most satisfactory of all tulips for outdoor planting. 10c each; $\$ 1.00$ per dozen.

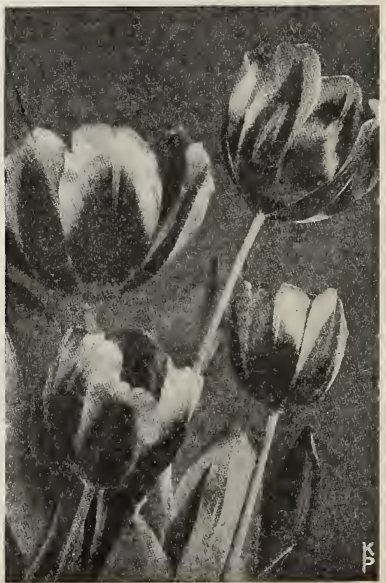

Darwin Tulips 


\section{Bulbous Plants for the Conservatory and Garden}

\section{Unsurpassed in bloom and foliage}

The bulbs of Oxalis and Callas can be delivered beginning in August, Freesias in September and not later than December 1st, Watsonias also in September and October. Amaryllis, Agapanthus, Begonia, Canna, Dahlia, Gladiolus, Iris Kaempferi, Lilium Auratum, Rubrum, Candidum, Humboldi and Parryi, Lily of the Valley, and Tuberoses can all be delivered as late as May 1st. We always have a stock of Amaryllis Vittata on hand at our nurseries and can make delivery nearly all the year around furnished in pots or dug from the open ground.

AMARYLLIS VITTATA. We have purcliased from Mr. Fred Rafferty his entire cliased from Mr. Fred Rafferty his entire ferty has spent many years improving the ferty has spent many years improving the
strain of Amaryllis Vittata, working with the idea of producing a pure white Amaryl lis. The bulbs in the collection are mostly white ground, with marking of red or pink, some of them producing almost pure white flowers. This strain is different from others offered in California. The bulbs we furnish offered in California, The bulbs we furnish
are all from 3 to 5 years old. Price, 25c a re all

AMARYLLIS BELLADONNA. This variety blooms right after the foliage disappears. The flowers are light pink and come in great profusion. Four-year-old bulbs, $15 \mathrm{c}$ each. Mammoth size, $25 \mathrm{c}$ each. AGAPANTHUS UMBELLATUS. Called the Blue African Lily. Very hardy plant, pro ducing blue flowers in great profusion all through the spring and summer. Clumps, $25 \mathrm{c}$ each; extra heavy, $50 \mathrm{c}$ per clump.

BEGONIA TUBEROUS ROOTED. Vari eties we offer are separate colors and of the erect flowering kind of the best grown Belgium grown strains. Each bulb, etc., single or double. In 5 -inch pots, $35 \mathrm{c}$ each.

CANNA. Our collection comprises all the leading varieties. Orchid flowering and all the latest ones out. Each $15 \mathrm{c}$, or $\$ 1.50$ per dozen.

CALADIUM ESCULENTUM or Elephant's Ears. So called on account of its enormous leaves which make it a very tropical looking plant of the first order. Clumps, $20 \mathrm{c}$ each; gal. cans, $50 \mathrm{c}$ each.

CYCLAMEN. Very hardy, a beautiful spring fiowering plant, growing anywhere where ferns or begonias will thrive. In $2 \frac{1}{2}$-inch pots, $15 \mathrm{c}$ each.

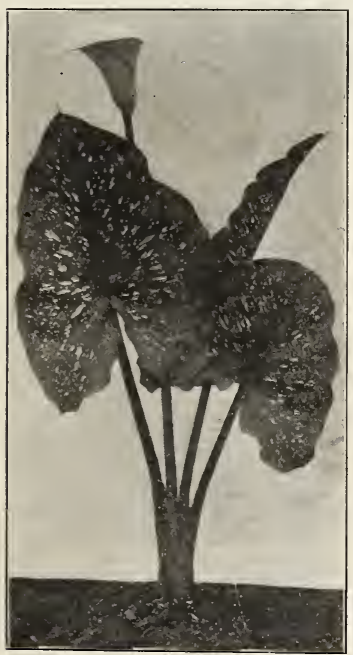

Calla Elliotiana
CALLA LILIES. We have three grades of these well known lilies, all flowering sizes. 1 -inch bulbs, 15c eacli: \$1.50 per dozen. Small plants out of $21 / 2$-inch pots, $10 \mathrm{c}$ each. $\$ 1.00$ per dozen.

CALLA LILIES. Spotted leaf or Richardia Meculata. Foliage of a beautiful dark green maculated with white, a very striking foliage plant producing white flowers like the com mon Calla. Bulbs, 35c each.

CALLA ELLIOTIANA. Flowers the same shape as the White Calla, but of a beau tiful golden yellow color. Leaves dark green covered with small white spots making this plant very attractive as a foliage or flowering plant. Two-year-old bulbs, 50c each.

DAHLIAS. We carry all the leading varieties of Dahlias, single and double, Cactus and Pompon varieties. No bulbous plant and Poinpon varieties. No bulbous plant will produce a more continuous crop of
flowers than the Dahlia in summer and fall flowers than the Dahlia in summer and fall The roots should be planted 3 inches below the surface in a rich sandy soil and plenty of water given during the growing season. The flowering stems should be carefully tied up as soon as they appear. Show Dahlias, Decorative Dahlias and Pompon Dahlias, $50 \mathrm{c}$ each for standard varieties. Novelties from $75 \mathrm{c}$ to $\$ 1.00$ each.

GLADIOLUS. Are considered the most valuable bulbous plants for Southern California; they can be planted from November all through the spring and almost any time that dormant bulbs can be secured. The strains we offer are of the very best large flowering kinds. We have sold Gladiolus fowering kinds. We have sold Gladiolus customers that have purchased have been more than pleased with the flowers that they obtained from our bulbs. Mixed $\mathrm{Hy}$ brids, $10 \mathrm{c}$ each; $75 \mathrm{c}$ per dozen.

Large flowering hybrids in separate colors, red, pink and white, $75 \mathrm{c}$ per dozen.

GLOXINIA ERECTA. In 5-inch pots, each, 75c. SPECIAL. Gloxinia in $2 \frac{1}{2}$-inch pots, $25 \mathrm{c}$ each.

FREESIA PURITY. Producing flowers of which 90 per cent are pure white. The bulbs we offer are of the Fischer's Purity strain and can be well recommended. Per dozen, $25 \mathrm{c}$; per $100, \$ 1.75$.

FREESIA RAINBOW. New strain of Free sias of all shades and colors. A fine mix ture. $75 \mathrm{c}$ per dozen.

SPANISH IRIS. In separate colors, yellow, wlite, brown or mixed. $75 \mathrm{c}$ per dozen $\$ 5.00$ per 100 .

WATSONIAS. Watsonias have a very short period of rest in Southern California and we can only deliver them during September and October. The Watsonia is one of the most beautiful additions to the Southern California collection of bulbs. Flowers of the purest white produced on stems 4 to 5 feet high, one of the finest flowers for cutting and decorating. Watsonias are in bloom about Easter and in order to have these flowers in at that time the bulbs should be planted in October or November. We are growers of Watsonia bulbs and can offer them in white at $5 c$ each, $50 c$ per dozen, and the hybrid varieties in shades or red and pink at $10 \mathrm{c}$ each, $\$ 1.00$ per dozen.

TUBEROSE. Double Pearl. Eastern grown bulbs of the double large flowering varieties. Per bulb, $10 \mathrm{c}$, or $\$ 1.00$ per dozen Delivered during January, February and March.
BERMUDA LILY. Large bulbs, 25c each.

LILIUM AURATUM. One of the most beautiful lilies in existence. The flower is of a golden yellow, spotted with red. The flower stems grow from 2 to 3 feet high, and of all the lilies this is the most desirable and showy. $25 \mathrm{c}$ each

LILY-OF-THE-VALLEY. Strong Pips, per doz., $\$ 1.00$.

LILIUM RUBRUM. Grows to the same size and height as the Lilium Auratum but the flowers are of a beautiful dark red. $25 \mathrm{c}$ each.

LILIUM CANDIDUM. The old white Lily or St. Joseph Lily. $15 \mathrm{c}$ each.

OXALIS. Oxalis planted in August will cone in bloom in December and will furnish flowers during Christmas and New Year's. They are about the best flowering plant that we have for winter flowering in our gardens. As potted plants or in hanging baskets they are always desirable. The varieties we offer are all large flowering and worthy of a place in every garden or in worthy of a place in every garden or in
the house or on the porch with other potted the house
plants.

Bermuda Buttercup. $35 \mathrm{c}$ per dozen, or $\$ 2.50$ per 100 .

Grand Duchess. Lavender, 35c per dozen, or $\$ 2.50$ per 100

California Rosea. Pink. Per dozen, 35c, or $\$ 2.50$ per 100 .

Oxalis Herti (New). This is a valuable ad dition to the Oxalis list. It is suitable for hanging baskets and window boxes on account of its drooping habit. The growth of this Oxalis is entirely different from others, the foliage resembling somewhat the Asparagus Springeri, and having a flower at every joint of the branches that hang down from 10 to 18 inches over the pots or boxes, Price, $40 \mathrm{c}$ per dozen.

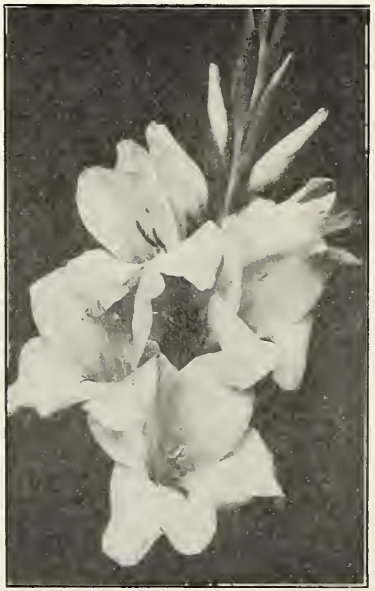

Gladiolus 


\section{A Superb Collection of Roses for the Rose Garden}

There is no flower that lends greater charm or beauty to a garden than the rose. Its delicate fragrance and exquisite colors are a decided attraction in any garden, filling a place that is uniquely its own. Listed below will be found a selection including the proven late introductions and the old reliable varieties, each the best in its class, in bush and climbing sorts. We suggest an early placing of your order to avoid disappointment. PRICE 75c each.

\section{White Bush Roses}

ANGELUS (New). One of the best rose novelties of recent years; makes very fine buds and good flowers in great profusion.

WHITE COCHET. An old favorite. Flowers very double, slightly tinged with pink on the outside of petals.

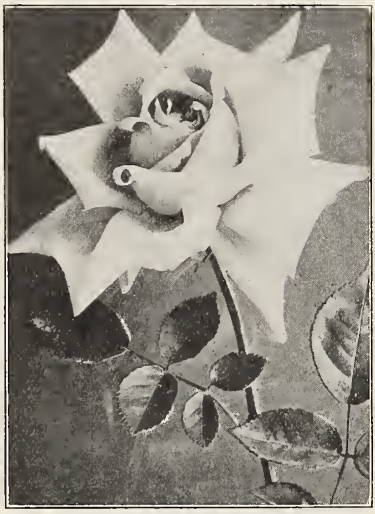

White Cochet

DRUSKI. A so-called white American Beauty. Flowers very large, slightly tinged with pink on outside; very vigorous. This commonly called the Cabbage Rose.

WHITE KILLARNEY. This rose has been introduced for several years and has proven to be one of the best white varieties on the market. The buds are very long and almost pure white.

ANGELENA or BUSH MRS. PEARY. Flowers very double and are sulphur white.

\section{Pink Bush Roses}

COLUMBIA. A recent introduction; a hybrid tea rose; good bloomer.

CLARA WATSON. Another hybrid tea rose; salmon tinged with pink. A good rose for cutting.

DEAN HOLE. A profuse bloomer: very solid buds and the flowers open out very full.

MME. ABEL CHATENAY. An old favorite; clear pink, almost white at the edge of the petals.

CECIL BRUNNER. Also called the Buttonhole Bouquet Rose. Most perfect small flowers of salmon pink color and delicate fragrance.

MY MARYLAND. Dark pink; long buds; good bloomer.

PINK RADIANCE. One of last year's introductions; very good bloomer and grower; beautiful long buds.
WINNIE DAVIS. A light flesh pink; very strong grower and profuse bloomer.

PINK KILLARNEY. Another novelty of recent years; has proven its worth in any locality; buds are shell pink; very long.

CHARLES RUSSELL (New). A good pink; good bloomer worthy of a trial.

LOS ANGELES. This is one of the greatest roses ever introduced and we are about to offer this local novelty at the same price as the other roses. Scarcity of the stock make this rose almost prohibitive to the average people, it being sold now with the other people, it being sold now with the other
varieties. No rose collection should be varieties. No rose collection should be
without it. The flower is not a clear pink without it. The flower is not a clear pink
but a mixture of pink, yellow, apricot and copper yellow.

PAUL NEYRON. One of the largest pink cabbage roses grown. Flowers produced on long canes; a good spring bloomer.

ULRICH BRUNNER. A first class sport of the Paul Neyron rose; branches clean and vigorous with almost no thorns. This rose resembles very much the American Beauty. While the American Beauty thrives tnly in a few favorite localities the Ulrich Brunner will produce good flowers in any garden almost the year around.

GEORGE AHRENDS. Clear pink ; good grower; is sometimes called the Pink Kai. serin.

MRS. JOHN LAING. Another hybrid perpetual; light pink; cup shaped flowers.

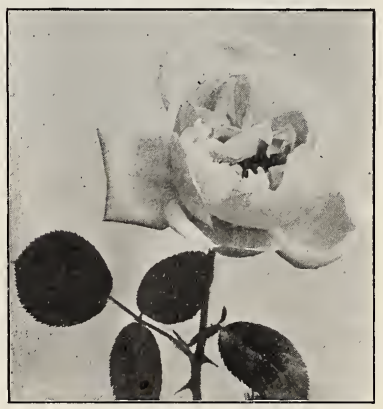

Mrs. John Laing

\section{Red Bush Roses}

RED RADIANCE. A beautiful red rose of recent introduction; a dark crimson; flower very fragrant.

GENERAL McARTHUR, Hybrid tea. Color the most beautiful crimson. It is also one of the sweetest varieties. It is a good, strong, vigorous grower, producing stems 24 to 30 inches long, a free and continuous bloomer. It is a good red rose for every man's garden.

ETOILE de FRANCE. Hybrid tea. A charining French variety; has large fine buds borne singly on long stiff stems; dark crimson in color; center vivid cerise; frag. crimson in color; center vivid cerise; fragforming a fine upright brush with few forming a fine upright brush with few
thorns.
HADLEY, Hybrid tea rose of a dark red; very fragrant.

K OF K. Hybrid tea rose. Semi-double of a scarlet color.

PRIMA DONNA. Another hybrid tea. Good bloomer; very deep pink; fragrant.

MY LADY. Hybrid tea. Good brilliant red; large flowers; very fragrant.

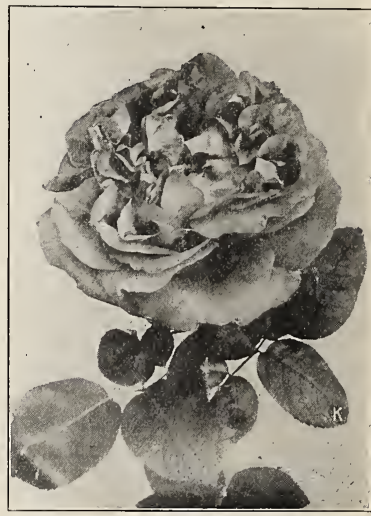

Paul Neyron

\section{Yellow or Mixture of Yellow}

MRS. AARON WARD. Hybrid tea rose; yellow; deep apricot at the base of the petals. SUNBURST. Hybrid tea rose; yellow, edge of petals slightly fringed.

HELEN ARMACOST (New). A deserving new variety, having been tried at our trial gardens; promised to be one of the best of its class; almost clear yellow.

WM. DREER. Salmon yellow; good bloomer; deep scented.

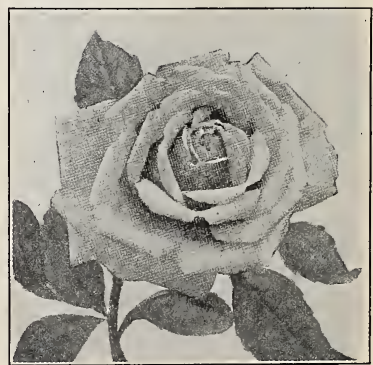

Los Angeles 
ED HARRIOTT. Very good yellow; slightly tinged dark copper.

PERLE D'OR, or Yellow Cecil Brunner. This is one of the daintiest small roses in cultivation and is the exact size and shape of the pink Cecil Brunner; an ever bloomer. OPHELIA. Hybrid tea; salmon yellow shaded to flesh; good bloomer.

GOLDEN OPHELIA (New). A valuable novelty of a rich golden yellow; fine buds and good flowers.

MME. BUTTERFLY. Hybrid tea: salmon yellow; a rose of recent introduction.

MRS. A. R. WADDELL. A copper pink; greatly appreciated by rose lovers.

MME. VERMOREL. Good yellow, shaded" slightly apricot and salmon.

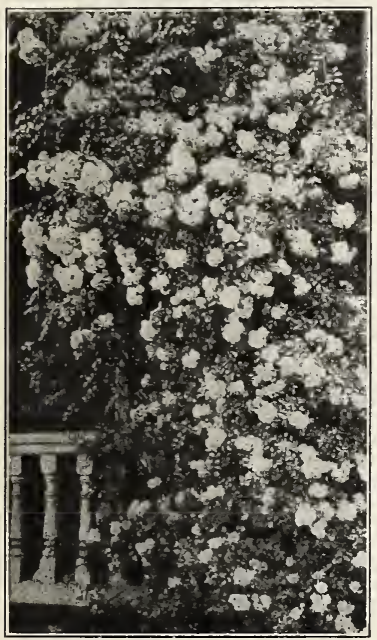

La Marque

\section{Climbing Roses}

CLIMBING LADY ASHTOWN. One of the latest novelties in climbing roses; a strong grower producing large pink flowers in great abundance.

CLIMBING BELLE SIEBRECHT. A clear pink; a very scarce rose making long buds in great profusion.

REVE D'OR. Has been scarce for a number of years, and we have only a limited number of them to sell. One of the few yellow climbers that stand the California sun flowers are large, very double and sweet scented; come in great profusion all the year round.

DUCHESSE D'AUERSTADT. This is the only climbing yellow rose that resembles the Marechal Niel and stands the California sun better than any yellow rose known. It has the same fragrance as the Marechal Niel and is in bloom almost the year around.

CLIMBING PINK COCHET. A good climber; the buds are very large and the flowers open up very double; a profuse bloomer.

WHITE COCHET. Same as above. Flowers white, slightly tinged pink on the outside petals.

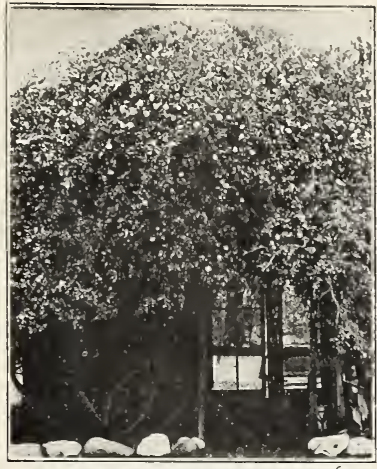

Climbing Cecil Brunner

CLIMBing CAROLINE TESTOUT. Pro duces large pink flowers the same shade of pink as the La France; one of the strong. est and most vigorous growers.

CLIMBING CECIL BRUNNER. One of the most vigorous of climbing roses; a perpetual bloomer producing small salmon pink flowers in great clusters. The foliage o for pergolas or porches.

CLIMBING ROBERT PEARY. Flowers immensely large, full, deep and double: they are of excellent substance and are produced on long, stiff stems. The buds are long and pointed, a remarkable feature not found in any other climbing rose. Similar to the bush variety; white, slightly tinged with sulphur; perpetual bloomer.

CLIMBING GRUSS AN TEPLITZ. Flowers light scarlet shaded to a deep rich velvety crimson; in bloom all the year around strong grower.

CLIMBING PAPA GONTIER. This mag nificent variety is a native sport from the old favorite bush Pape Gontier, with characteristic arid-climate vigor and productive ness. It has the same splendid cheery red flowers, beautifully shaped buds, long stems, and in addition has a long climbing habit of growth. It is very popular in all localities where the bush variety does well.

CLIMBING WINNIE DAVIS (New). A hy. brid tea rose; clear pink; good grower.

LA MARQUE. One of the oldest white climbing roses in existence, has never been equalled where a white rose is desired to cover arbors and pergolas.

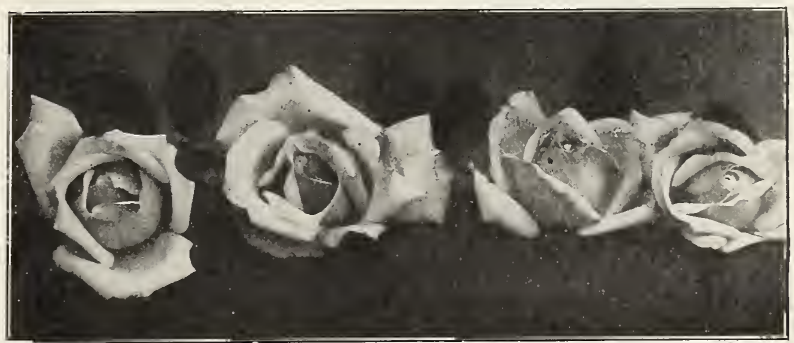

PAUL SCARLET (New). Good addition to the list of climbers; flowers brilliant scarlet; large, produced in great profusion. the flowers are ut as large as the bush American Beauty they are of the sime cx. quisite cerise pink shiade and are produced in great profusion, especially in the spring. The foliage is entirely different from any other rose, being a dark glossy greell. makes a very attractive

SILVER MOON. Very scarce; also called the White Cherokee. Very large silver white single flowers, very beautiful and at tractive

DOROTHY PERKINS. This variety makes long runners and is especially adapted for fences and trellises; profuse bloomer, especially in the spring when a whole bunch of small pink flowers come out at every joint.

THOUSAND BEAUTIES. An old reliable variety; strong grower, almost thornless. flowers in the spring.

CHEROKEES. We have both the pink and red varieties, the red being sometime called Ramona. They are both very desirable; a profusion of flowers in the spring.

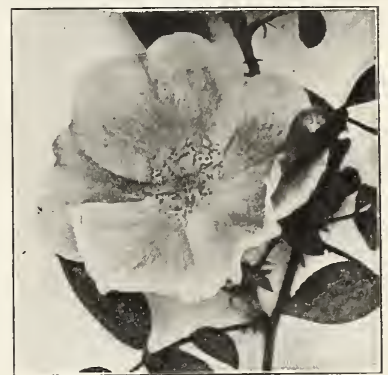

Cherokee

We keep all these varieties in stock at our yard, 49th and Main Streets. They can be furnished all the year around, put up in 1 gallon containers. They are thoroughly established and will give immediate results,

Climbing Lady Ashtown
CLIMBING AMERICAN BEAUTY. While 


\section{Choice Decorative Plants and Ferns}

\section{For the House, Garden and Porch}

ARBOR VITAE. A great favorite for formal decoration for either the garden or porch. Very compact and regular in habit. Foliage assumes a beautiful golden tint in the spring. Either ball shaped or pyramidal, nice plants 2 to $2 \frac{1}{2}$ feet high, balled, $\$ 2.50$ each. In pots or tubs the price varies ac-
cording to style and price of the receptacle.

ABIES NORDMANNIANA (Nordmann's Silver Fir). Very symmetrical; foliage slightly, green, shining above and hardy; an exceedingly handsome and majeshardy; an exceedingly handsome and
tic fir. Two feet high, $\$ 4.00$ each.

ARAUCARIA EXCELSA (Norfolk Island Pine). The variety best known and the hardiest. Fine for house decorating. Nice plants in 6 inch pots, three or four tiers. high at the rate of $\$ 1.00$ per foot.

ARAUCARIA BIDWILLI (Bunya Bunya) A native of Morton Bay, Australia. A magnificent plant with branches in regular whirls closely set with spiney, shining deep green leaves. Very handsome and extremely hardy. Prices on application.

ASPARAGUS SPRENGERI. The most popular of basket or pot plants. Each $50 \mathrm{c}$.

ASPARAGUS PLUMOSUS (Asparagus Fern). Fine for pot plants or cutting. Each, 50c.

AZALEA. 10 to 12 inch crown, 6 inch pot, plants in bud, $\$ 5.00$ each.

BAY TREES. There is a great demand for this superb decorative tree which is used extensively for decorating halls, porches and gardens. The prices will be better appreciated if the trees are examined and compared.

BEGONIA (Rex). Immense leaves spotted with green, silver, bronze and an endless variety of shades. One of the finest plants for house decoration. Large plants with four to six leaves, $\$ 1.00$ each.

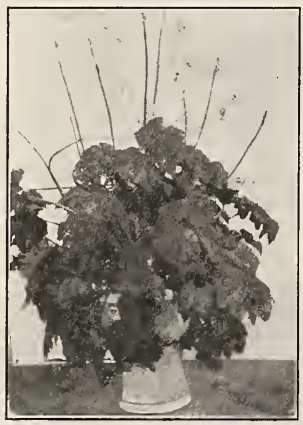

Begonia Ricinifolia

BEGONIA RICINIFOLIA. This Begonia produces leaves resembling those of the Castor Bean Plant. The back of the leaves are flesh color, and the flowers come in immense bunches. A very hardy Begonia and easily grown in the house. Plants in 7 -inch pots, $\$ 1.00$ each.

BEGONIA VERNON. Splendid as a pot plant or for bedding. Small plants $10 \mathrm{c}$ each; 50c per dozen, or $\$ 3.00$ per 100. Large plants, $25 \mathrm{c}$.
Begonia aRgentea guttata. Purple brown leaves with silver blotches. Each, $25 \mathrm{c}$.

BEGONIA TUBEROUS ROOTED. These plants are in full bloom from July until the first of November. We can furnish these plants any time during their flowering season at the rate of $35 \mathrm{c}$ each. From Decemson at the rate of $35 \mathrm{c}$ each. From Decem-
ber and all through the spring we deliver ber and all through the spring we deliver
the dry tubers at the rate of $25 \mathrm{c}$ each for the single varieties and $35 \mathrm{c}$ for the double.

BOXWOOD. This is another very popular and beautiful plant for which the demand is great. We can furnish these plants at $50 \mathrm{c}$ each, 12 inches high. The next size is about 2 feet high, pyramid shape, at $\$ 2.50$ each. feet high, pyramid shape, at $\$ 2.50$ each. Either pyramids or standards, $31 / 2$ feet high,
$\$ 4.00$ each. This year we have some par$\$ 4.00$ each. This year we have some par-
ticularly fine specimens in the ball shaped plants, which are very closely grown and well shaped, standing about 2 feet high in 16 -inch tubs at $\$ 6.00$ each. We can also furnish the small plants of Boxwood for hedges at $75 \mathrm{c}$ per dozen, or $\$ 4.00$ per 100 , Nothing is of more satisfactory growth, be Nothing is of more satisfactory growth, be-
sides adding to the beauty of lawn and garden.

FARFUGIUM GRANDE (Leopard Plant). A hardy ornamental plant with circular leaves which are spotted with creamy white and yellow. Makes a nice pot plant, or for planting in shady locations with ferns and begonias. 5-inch pot plants, $\$ 1.00$ each.

LOTUS. These plants resemble the Asparagus Sprengeri in habit of growth, but have a bluish gray foliage. They produce quantities of red blossoms all the year around. They are about the only plant that will grow and bloom in hanging baskets around Los Angeles; they like the good, warm sunshine the greater part of the day. Plants in 4-inch pots, 25c each. Large plants in hanging baskets, $\$ 1$ to $\$ 2$ each.

PHOENIX ROBELENI. This is a dwarf variety of the Phoenix Palm, resembling
somewhat the Cocos Weddliana, but much somewhat the Cocos Weddliana, but much
hardier. An ideal plant for house decoration. Prices according to size.

RUBBER TREES. These plants are very valuable in decorating houses or windows and stand more hardship than any othe house plant. The leaves are easily cleaned by rubbing with a soft cloth or sponge. Nice plants 12 to 16 inches high, $\$ 1.00$ to $\$ 2.00$ each. Your choice from two varieties, Ficus Elastica and Ficus Macrophylla.

RHODODENDRONS. Good healthy bushes, 5 to 6 stalks, well budded. $\$ 2.50$ each.

SANSEVIERA ZEALANICA. An elegant variegated plant, especially adapted for the house decoration. The thick, leathery leaves stand the dust of the house. Six-inch pots, $75 \mathrm{c}$ each.

SAXIFRAGA SARMENTOSA. Light green foliage with sliver markings, the under side of the leaves being red. This plant makes runners like a Strawberry plant. The long runners like a Strawberry plant. The long runners hanging from the mother plant in hanging baskets. Price, $25 \mathrm{c}$.

\section{Ferns for the Conservatory and Garden}

ADIANTUM CUNEATUM (Maiden Hair Fern). This is the variety used by florists for cutting and for filling fancy pots and baskets. Five-inch pot plants, $\$ 2.00$.

BOSTON FERN. Nice plants in 5 -inch pots, $75 \mathrm{c}$ each. In 6 -inch pots, $\$ 1.00$ each. We have a large assortment of these ferns for hanging baskets and fern pans at reduced prices.

CYRTOMIUM. Bright green foliage. Each, 5 -inch pot plants, $\$ 1.00$.
NEPHROLEPSIS AMAPOHLI. The latest lovelty in the fern line. The fronds are of such a fine and graceful texture that they excite the admiration of all who behold them. It is a beautiful decorative plant fo the house. Five-inch pots sell at $\$ 1.00$ each and 6 -inch pots for $\$ 1.50$.

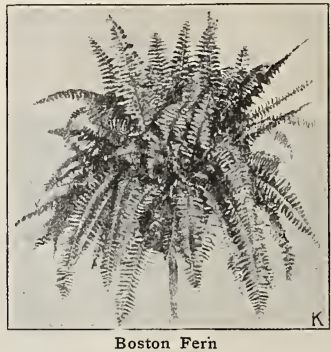

NEPHROLEPSIS EXALTA (Sword Fern) Hardiest of all sword ferns for outdoo planting. Small plants, $15 \mathrm{c}$ each, $\$ 1.50$ per dozen. 3-inch pot plants, $25 \mathrm{c}$, $\$ 2.50$ per dozen. Gallon cans, $50 \mathrm{c}$ each, $\$ 5.00$ per dozen.

NEPHROLEPSIS PIERSONI. Also called Double Fern, on account of an extra set of leaflets. Price $75 \mathrm{c}$ to $\$ 2.50$ each.

NEPHROLEPSIS WHITMANI. The most valuable of this type with numerous broad plume-like leaves, hence its name of Ostrich Plume Fern. Nice plants in 5 -inch pots, $75 \mathrm{c}$ to $\$ 5.00$.

PTERIS ALBA LINIATA. Hardy fern for fern pans, window boxes etc. The foliage is dark green having a white stripe through the center, making it different from othe ferns. Makes a nice contrast when planted with other ferns. Five-inch pot plants, $75 \mathrm{c}$ each ; 6 -inch plants, $\$ 1.00$ each.

PTERIS TREMULA, or Japanese Brake Fern. Used for house decoration and outof-door ferneries. Very hardy and easy to grow. Foliage resembles somewhat our native Brake Ferns. Five-inch pot plants, $50 \mathrm{c}$ each; 6-inch pot plants, $75 \mathrm{c}$ each. Small plants for bedding, $\$ 5.00$ per dozen.

WOODWARDIA, or California Brake Fern. These ferns are extensively used in planting ferneries around Los Angeles and all South ern California. They thrive in half shady places but must have leaf mould to grow in ; heavy roots, in boxes $12 \times 12,75 \mathrm{c}$ each; in 6 -inch pots, $75 \mathrm{c}$ each.

\section{Ferns for Bedding}

At our nursery, 49th and Main Streets, we have in stock a large assortment of young ferns, in small pots and in flats, including Maiden Hair Ferns, Pteris, and six varieties of Cyrtomium Asplenium, which we offer at $15 \mathrm{c}$ each, $\$ 1.50$ per dozen.

Besides the native ferns, we carry an assortment of hardy Boston Ferns. Pteris, Cyrtom. ium, Asplenium, etc., for planting in shady ium, Asplenium, etc., for planting in shady places. These can be furnished from $\$ 1.00$ to making ferneries, the Asparagus Plumosus are used extensively in connection with the other ferns. They are used for stringing on the wall, which give a fine background for the fern bed when it is located against a building, and also furnishes beautiful greenery fing, and also furnishes beautiful greenery gus Sprengeri and Plumosus for this purpose
in clumps in 6 -inch pots or from the open ground at $50 \mathrm{c}$ each. 


\section{Selected Varieties of Perennial Plants}

The following eollection of plants ineludes the most valuable decorative and bedding plants that can be used in Southern California. They are valuable on account of their hardiness, ease of propagation and the fact that they do not have to be replaced every season. With proper selection of varieties a succession of flowers can be had all the year around in Southern California. Marguerites, Pentstemon, Petunia, Peremnial Larkspur, Lobelia, Shasta Daisies, Verbena and many more will be in bloom all the year around.

AQUILEGIA (Columhine). each, $\$ 1.50$ per dozen.

ATROSANGUINEUM. Large dark crimson flowers.

BEGONIA, Vernon, Gracillis or Luminosa, and all other bediding varieties, In flats, $50 \mathrm{c}$ per dozen, $\$ 3.00$ per 100 .

BOXWOOD. This popular and well known horder and hedge plants has been very horder and hedge plants has been very
scarce in our part of the state. We are propagating it in large quantities and are able to furnish it at reduced rate. Each, $75 \mathrm{c}$.

CINERARIA. In 2 -inch pots, $15 \mathrm{c}$ each, $\$ 1.50$ per dozen.

CANNAS, FIREBIRD. This is the most striking of all the Cannas. The flowers coming in large double bunches of a fiery crimson color and are produced in great profusion in summer and winter, the leaves are of the cleanest green, and of all varieties grown in Los Angeles this is one of the prettiest ever introduced. Bulbs, $15 \mathrm{c}$; $\$ 1.50$ per dozen.

CANNAS. Twenty standard varieties. Each, $15 \mathrm{c}$; per dozen, $\$ 1.50$. See Department on "General Collection of Bulbs."

CAMPANULA (Canterherry Bell). Two-yearold plants in 3 and 4 -inch pots, $15 \mathrm{c}$ each $\$ 1.50$ per dozen.

CARNATIONS. We carry a stock of the hardiest varieties that are used hy florists for outdoor growing in Southern California, and which produce the most and best flowers out of doors. No garden should he without a bed or border of Carnations. They are easily grown in sandy soil or They are easily grown in sandy soil or
where soil is heavy, a little addition of sand will enable anyone to have a nice bed of carnations. Plants in pots, $75 \mathrm{c}$ per dozen. Large plants, field grown, $25 \mathrm{c}$ each.

CHRYSANTHEMUMS. Plants in 3-inch pots, all the leading varieties in separate colors, white, pink, red and yellow, and all variegated and fancy varieties. The prize winners of Eastern flower shows. Price, $75 \mathrm{c}$ per dozen.

CENTAUREA CANDIDISSIMA. This is the Dwarf White Dusty Miller. Makes nice contrast when planted for border around red flowering or foliage plants. Plants in 3 -inch pots, $\$ 1.50$ per dozen.

CENTOLINA. Makes a permanent border of a heautiful silver gray color; can be kept rimmed from 6 to 12 inches in height, hut the huds must be kept cut, for as soon as they appear the border will grow out of shape. Per dozen, 50c, or $\$ 3.00$ per 100 .

COLEUS. Three-inch pot plants, in all shades and colors imaginahle, $15 \mathrm{c}$ each $\$ 1.50$ per dozen.

COREOPSIS. Very useful and hardy annual. Flowers golden yellow and showy. Fine for large heds as well as for cut flowers. We have some heavy two-year-ola flumers. We have some heavy two-year-old
clumps ready to blossom, 25c each; $\$ 2.50$ clumps ready.

CYPRESS FOR HEDGES. The Monterey Cypress makes a wind and dust-proof hedge for suburban homes and is especially valuable where the ocean winds are strong. Per box of $100, \$ 2.50$.

DAISIES, ENGLISH. All colors, mixed. This is the old-fashioned English Daisy; They come in white, pink or red. We can supply them mixed or separate colors at $35 \mathrm{c}$ per dozen, $\$ 3.00$ per 100 .

DIGITALIS (Fox Glove). Two-year-old clumps from the open ground, $25 \mathrm{c}$ each, $\$ 2.50$ per dozen.
FERNS. For bedding (see list of decorative plants). We propagate ferns on a large scale and are ahle to quote many varieties at very low prices.

GAZANIA. In flats, 50c per dozen; $\$ 3.00$ per 100.

GOLDEN ROD. Two-year-old clumps, $50 \mathrm{c}$ each.

GOLDEN GLOW (Rudheckia), Two-year old clumps, $50 \mathrm{c}$ each.

GAILLARDIA GRANDIFLORA. Plants out of flats, $50 \mathrm{c}$ per dozen,

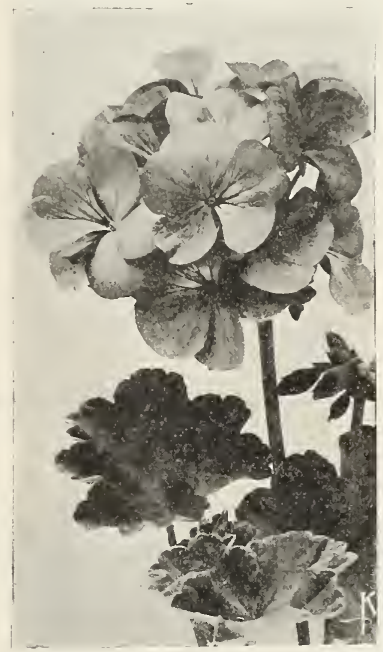

Geranium

GERANIUMS (Madam Salleroi). Good plants for borders, seldom growing over 6 inches in height. Green foliage edged with white. $50 \mathrm{c}$ per dozen, or $\$ 3.00$ per 100.

GERANIUMS (Ivy Leaved). Large flowering double pink or red varieties. In pots, $15 \mathrm{c}$ each, $\$ 1.50$ per dozen.

GERANIUMS. General Grant and other leading varieties, $35 \mathrm{c}$ each.

GERBERA JAMESONI (Transvaal Daisy). A rare plant on account of the difficulty in proparating. Large daisy-like blossom. Leaves about one foot long and deeply cut. A very beautiful plant. Blossoms 3 to 4 inches across. We can furnish this beaut ful perennial in vermilion-crimson, red, orange, pink and yellow. Small clumps, 50c each; large clumps, $\$ 1.00$ each.

GEUM (Avens). Pretty border plants, grow ing ahout 18 inches high and producing showy, hright colored flowers the greater part of the fall and summer.

COCCINEUM. Brilliant scarlet flowers, $25 \mathrm{c}$ each; $\$ 2.50$ per dozen.

HOLLYHOCKS, CHARTER'S HYBRIDS. Very best douhle, large flowering. Price, $25 \mathrm{c}$ each; $\$ 2.50$ per dozen.
HELIOTROPE. In pots, $25 \mathrm{c}$ to $50 \mathrm{c}$.

LANTANA COMPACTA NANNA. Dwarf varieties for borders; in pots, $15 \mathrm{c}$ each, $\$ 1.50$ per dozen.

LAURUSTINUS. For Hedges. Plants in 4.inch pots, suitable for hedges, $25 \mathrm{c}$ to $35 \mathrm{c}$ each.

LOBELIA. Dwarf growing; dark blue flowering variety. Per dozen, $35 \mathrm{c}$, or $\$ 2.50$ per 100

MESEMBRYANTHEMUM FLORIBUNDUM (Ice Plant). In flats, $25 \mathrm{c}$ per dozen; $\$ 2.50$ per 100 .

MARGUERITES. Yellow or white varieties. Pot plants, $25 \mathrm{c}$ each, or $\$ 2.50$ per dozen.

MARGUERITES. The new Mrs. Saunders. A decided improvement on the old variety with the yellow center. It resembles very closely the quilled aster. It is perfectly double and in hlossom all the year around. A splendid plant for bedding or borders and ahsolutely indispensable to those growing cut flowers or cuttings. Plants in pots, $15 \mathrm{c}$ each; $\$ 1.50$ per dozen.

MYRTIS MICROPHYLLA Small leaved Myrtle, Makes a good, permanent border Can he trimmed from 3 inches to 2 feet high. Should he planted about 5 inches apart to make a nice continuous horder. The foliage is green and shiny. $15 \mathrm{c}$ each.

PERENNIAL LARKSPUR. Two-year-old clumps, $50 \mathrm{c}$ each.

PELARGONIUM. This plant is a favorite with everyone. Our collection comprises all the leading varieties; plants can he bought in hloom almost any time. Customers that are not familiar with the names can pick out the varieties they prefer for $25 \mathrm{c}$ each.

PENTSTEMONS. Plants we offer are from European Prize Strain of the variety called Gloxinoides, one of the prettiest and largest flowering species ever produced; plants are of compact growth and literally covered with spikes of very large flowers; colors vary, white, pink, red, dark red. Price $\$ 1.50$ per dozen. Large plants, one year old, $25 \mathrm{c}$ each.

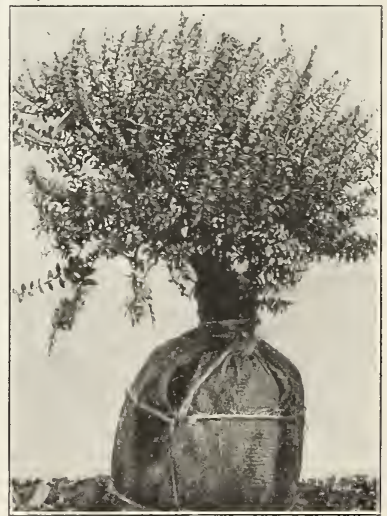

Myrtus Microphylla 
PETUNIAS. One of the best plants to withstand our warm summers; they grow and bloom without much water and, in fact, flower to perfection in deep rich soil with water put on by irrigation. Ruffled single per dozen. Double, in pots, $25 \mathrm{c}$ each, $\$ 2.50$ per dozen.
per dozen.

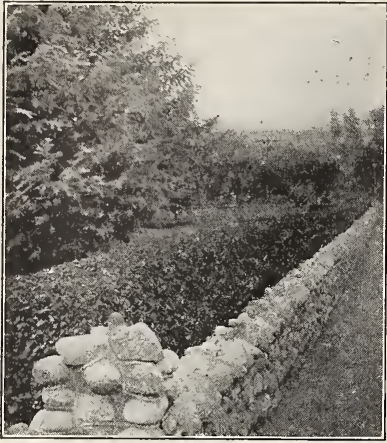

California Prive

PRIVET. We carry three varieties of Privet. The larger leaved Ligustrum Californicum and the small leaved Nepalense, and the Golden Leaved. All make a nice hedge. Three or four months of the year they are Three or four months of the year they are
covered with white blossoms resembling the Lilac. Green leaved, 50c dozen, $\$ 2.50$ per 100; Golden leaved, 75c dozen, $\$ 5.00$ per 100
HARDY PHLOXES. Among hardy perennial plants no class is of more importance than the Phloxes, succeeding in almost any soil and position, and flowering through soil and position, and flowering through long and pontinue in good condition and flower freely for many years without attention, yet they respond quickly to and are improved by liberal cul tivation. Leading strains, $35 \mathrm{c}$ each; $\$ 3.50$ per dozen.

PYRETHRUM AUREUM. Makes a nice golden border. Per dozen, $35 \mathrm{c} ; \$ 2.50$ per 100 .

PRIMULA MALACOIDES. A striking new variety. The flowers are borne around the central stem in dense whorls with several
of these to each stem. It reminds one of gigantic form of Primula Forbesei, but with brighter colored and much larger blooms. This handsome species will be of great value for shady rockery planting or for growing in pots as an ornamental flowering plant. Price, each, $20 \mathrm{c}$; per dozen, $\$ 2.00$.

SALVIA SPLENDENS. Valuable plants for summer flower beds, throwing up the most desirable scarlet flowers. Plants out of flats, $50 \mathrm{c}$ per dozen; in 3 -inch pots, $15 \mathrm{c}$ each, or $\$ 1.50$ per dozen.

SHASTA DAISY. Immense bloomer; white flower with yellow center; plants are perennial and bloom through the year. One of the best plants for cut flowers or flower beds. 50c per dozen. Plants in pots, $15 \mathrm{c}$ each; $\$ 1.50$ per dozen.

STATICE. We have in stock Statice Latifolia, the perennial variety with blue flowers. A Status with pink flowers growing to about one-half the height of the Latifolia and a small dwarf perennial variety with pink small dwarf perennial variety with pink flowers especially adapted for borders as it
does not grow over six inches high. The does not grow over six inches high. The dwarf pink varieties for borders are $50 \mathrm{c}$ per dozen: $\$ 3.00$ per 100 .
VERBENA. This plant and the Petunia are certainly the leading ones for planting flowe beds, parking and also used in coverin banks where it would be hard to grow Verbenas, like Petunias, do rich soil and by sub-irrigation, $10 \mathrm{c}$ each, $\$ 1.00$ per dozen.

VIOLETS. Blue California and Princess va rieties, $50 \mathrm{c}$ per dozen.

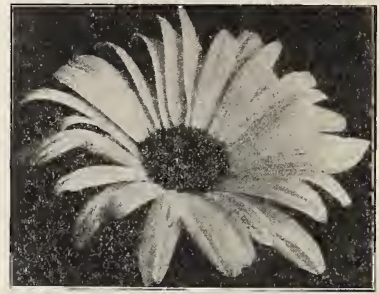

Shasta Daisy

VINCA, MADAGASCARIENSIS. The bushy "Periwinkle" in pink and white flowering varieties. Five-inch pot plants, $25 \mathrm{c}$ each.

VINCA MAJOR. One of the best plants for covering banks and for planting in shady places where a lawn will not thrive. It is one of the hardiest vining plants in existence, and will stand extremes of heat and cold better than any other border or bedding plant. When planted for beds or bordcrs it should be planted 10 inches apart. Price, $15 \mathrm{c}$ each; 2 for $25 \mathrm{c} ; \$ 1.00$ per dozen.

\section{Roselle}

This sun-loving annual should find a place in every home vegetable garden. The pods or fruits of a deep rich red are valuable for making jelly. They are produced the first season from seed and are very easily grown. The entire fruit or pod including the calyx is cooked to obtain the liquor that is used for making the jelly. The whole plant is of a mucilaginous nature which makes it so valuable for this purpose. The jelly is a rich deep red when the Roselles are used alone and of a lighter red when the Roselles are mixed with apples. They can also be mixed with guavas and other fruits, making a delicious and attractive jelly. This plant is not only useful, but is very ornamental as well and will greatly beautify the home vegetable garden as it makes very attractive borders and a good backing for smaller plants. It can be sown almost any time of the year. Sow in boxes and transplant. Per package, 10c; per oz., 50c.

ANTIRRHINUM (Snap Dragon). Do not fail to plant some of these favorites. In flats, $35 \mathrm{c}$ per dozen.

ASTERS. We grow the very best Branching and Comet Asters from our own seed, and are in a position to furnish first class plants that will come true to name and color. We can supply them in pink, crimson, lavender, purple and white Price $35 \mathrm{c}$ per dozen; $\$ 2.50$ per 100.

cosmos. Large flowering. A very striking flower; pure white with yellow center; $35 \mathrm{c}$ per dozen; $\$ 2.50$ per 100 .

\section{Popular Annuals}

PHLOX DRUMMONDI (Annual). We are growing these popular plants in mixed colors. They are very showy and make good borders and flower beds all the year good borders and flower beds all the yea
around. Per dozen, $35 \mathrm{c}$; per $100, \$ 2.50$.

PANSIES. From Steele's celebrated seed We have extensive seed beds this year, and exceptionally strong plants raised in the open ground and transplanted in flats, when large enough for delivery. We can furnish them from the first of January until the first of June at $40 \mathrm{c}$ per dozen, or $\$ 3.00$ per 100 .
STOCKS. The raising of stock plants is one of our specialties. We are increasing our sales every year on account of the thrifty plants that we furnish at moderate prices. These stocks are grown from the very best seed imported from Europe. Per dozen, $40 \mathrm{c}$; per $100, \$ 3.00$. Separate colors or mixed.

ZINNIA. A hardy annual. A welcome and valued addition in any garden; ideal for most any location or environment. All colors mixed. $40 \mathrm{c}$ per dozen; $\$ 3.00$ per 100. and depth of soil, location and climatic conditions, together with such other data as concerns the success of your planting. We will gladly give the information that our many years study of conditions in this Advisory Departinent, Winsel-Gibbs Seed Company, 211 South Main Street, Los Angeles, Cal. 


\section{Climbing and Trailing Plants \\ For Covering Porches, Pergolas, etc.}

AMPELOPSIS VEITCHI (Boston Ivy). Foliage crimson before dropping in the fall. Plants in 4 -inch pots, $25 \mathrm{c}$; in 5 -inch pots, $35 \mathrm{c}$ each.

AUSTRALIAN PEA VINE (Dolichos Lignosus). One of the quickest growing plants for covering fences and buildings, producing a pea-shaped flower growing inclusters. Yrice, $15 \mathrm{c}$ each; $\$ 1.50$ per dozen.

BOUGAINVILLEA LATERITIA. Red flowering or rather brick red color, variety. Plants in 5 -inch pots, $\$ 5.00$.

BOUGAIVILLEA SPECTABILIS, The most popular variety of all; grows in any location, especially in southern exposure. We have a fine assortment of plants and offer extremely low prices; good, strong plants in 1-gallon cans, 50c each; 5-gallon cans, $\$ 1.00$ each; larger specimens up to $\$ 2.00$ each.

BIGNONIA VIOLACEA. This variety of Trumpet bears blossoms of a delicate mauve or violet color. The foliage is very attrac tive, being large oval and shining. Plants $11 / 2$ to 2 feet high, $\$ 1.00$ each.

BIGNONIA VENUSTA. Amber color flower ing vine which blooms in winter in Southern California; one of the best climbers; foliage brilliant green. Blooms from September to May. Plants in 5-inch pots, $75 \mathrm{c}$ each; 5-gallon cans, $\$ 2.00$ each.

BIGNONIA GRANDIFLORA. Large flower ing trumpet vine. 5-inch pots, $50 \mathrm{c}$ and $75 \mathrm{c}$ each.

BIGNONIA TWEEDIANA. A variety with small foliage clinging to everything it cones in contact with: golden yellow flowers. There is a cling to cement, stone, brick or any kind of a wall, and a great inany people are under the impression that the Ficus Repens is the only evergreen vine adapted for this pur pose and some get discouraged waiting for the Ficus to grow and cover the walls, chimneys, etc. We are not introducing a novelty, but have propagated this Bignonia in large quantities after noticing the satis. faction given by this vine on account of its quick growth, evergreen foliage and beautiful flowers and its hardiness. We have noticed this vine during our coldest winters and our warmest summers and always found it to resist the extreme heat and cold. Bignonia Tweediana is one of the most rapid of climbers and will cover large columns, wall and chimneys in one season. We are offering these plants in $2 \frac{1}{2}$-inch pots at $25 \mathrm{c}$ each; $\$ 2.00$ per dozen.

BIGNONIA SCHERRERII. One of the most handsome climbing plants in cultiva tion. Flowers are trumpet shape like th old variety, but the blending of orange and crimson produces a most striking effect. This Bignonia is a strong grower and will thrive in almost any kind of soil. Plants in 5 -inch pots, $\$ 1.00$ each.

CHAYOTE (Sechium Edule). One of the most rapid climbers in existence which is useful as well as ornamental. It is a remarkable vine for its quick growth and also the abundance of fruit it bears. These fruits are delicious when cooked as squash or served as cucumbers. Plants in pots, $25 \mathrm{c}$ each.

ENGLISH IVY. In 4 -inch pots, $15 \mathrm{c}$ each; 5-inch pots, 25c each. We grow large quantities of these vines and furnish price on large lots on application.

FICUS REPENS. A splendid small vine with very dark green foliage. This plant will cling to stone work and rockeries. The contrast of the light green foliage of its new growth upon the dark color of the old leaves makes it very attractive and very valuable plant. Plants in 3 -inch pots, $25 \mathrm{c}$ each; larger plants, $35 \mathrm{c}$ to $50 \mathrm{c}$ each.

IPOMOEA LEARI. Blue perennial moon flower. Price, 25c each.
HONEYSUCKLE. Six varieties, common yellow, white, red and variegated leaved variety.
each.

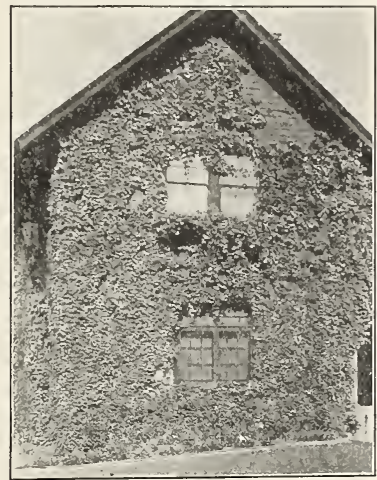

Ampelopsis Veitchi

JASMINE GRANDIFLORA. In 5-inch pots, $35 \mathrm{c}$ each.

Officinalis. In 5 -inch pots, $35 \mathrm{c}$ each.

Poetica. In 5 -inch pots, $35 \mathrm{c}$ each.

Gracillium. In 5 -inch pots, $35 \mathrm{c}$ each.

Grand Duke, In 5-inch pots, 35c each.

Maid of Orleans. In 5-inch pots, $35 \mathrm{c}$ each.

Revoluta. In 5 -inch pots, $35 \mathrm{c}$ each.

Floribunda. In 5-inch pots, 35c each.

MADERA VINE. Or Mignonette Vine. Dry tubers or plants established in 5-inch pots, $25 \mathrm{c}$ each.
MESEMBRYANTHEMUM FLORIBUNDUM. This is known as the Ice Plant around Los Angeles. This particular variety bears small pink flowers, which bloom in great profusion in the spring, making a perfect pillow. It is the most handsome of all Ice plants. It is of very easy cultivation and will grow where lawns or even particularly valuable for steep inclines, as particularly valuable for steep inclines, as established on a bank of earth or a stone wall it will keep it from washing. It makes most of its growth during the rainy season each year. Put up in flats, $18 \times 20, \$ 3.00$ per flat.

MUEHLENBECKIA COMPLEX. Apparently a most delicate and tender plant, but on the contrary it has demonstrated that it will do equally well on the coast and in the interior. It is a very rapid and showy climber, invaluable for covering walls, wire netting fences and for rock work. Its graceful spray like branches, its small thick waxy white flowers, followed by transparent, glistening, icicle like fruits in the fall, make it one of the best of our evergreen climb ers. 5-inch pot plants, $50 \mathrm{c}$ each.

PASSION VINE. Red, blue or pink. Each $35 \mathrm{c}$ to $50 \mathrm{c}$.

SMILAX. Clumps, each $25 \mathrm{c}$.

SOLANUM JASMINOIDES. White flower ing Potato Jasmine. Very fast growing with pretty white flowers; climber. 5-inch pot plants, $35 \mathrm{c}$ each.

TACOMA JASMINOIDES. Foliage of a very dark glossy green; flowers pure white inside tinged with a reddish purple, prac tically everblooming. $35 \mathrm{c}$ to $50 \mathrm{c}$ each.

VITIS CAPENSIS. One of the finest climb ing plants for covering arbors or pergolas. Makes a graceful vine and is of rapid leaf of the grape. It also resembles somewhat the Boston Ivy or Ampelopsis Veitchi. Plants in 4 and 5 -inch pots, $50 \mathrm{c}$ each.

WISTERIA. White or purple flowering. Large three-year-old plants, grafted, $\$ 1.50$ to $\$ 5.00$ each.

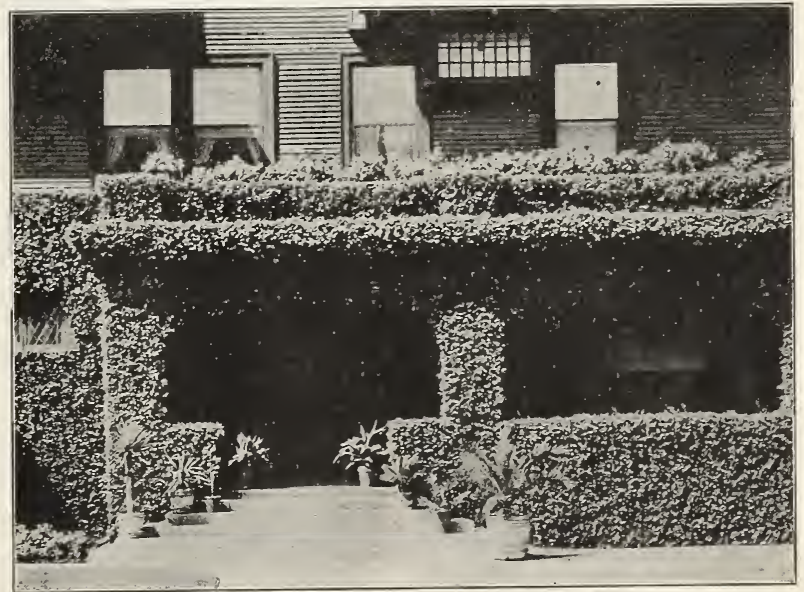

Ficus Repens 


\section{Popular Varieties of Ornamental Trees and Shrubs For Home Grounds and Landscaping}

ARBOR VITAE (Thurya Aurea). A great favorite for formal gardens, also for massing. Very compact and regular in habit, being rounded more or less and pyramidal being rounded more or less and pyramidal in shape. The foliage assumes a beautiful golden tint in the spring. One to two feet
high, $\$ 2.50$ each. Thuya Orientalis and Thuya Occidentalis at the same price.

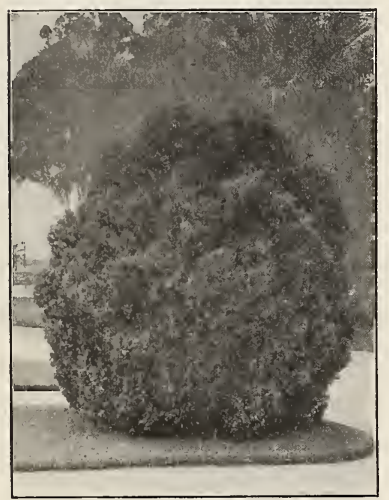

Golden Arborvitae

ABELIA RUPESTRIS. One of the best and hardiest shrubs for Southern California, harmonizes well with our native shrubbery, creamy white flowers; dark green shining creamy white flowers; dark gre
foliage. One gal. cans, $75 \mathrm{c}$ each.

AUCUBA JAPONICA (Gold Dust Plant or Japanese Laurel). Very handsome shrub. Curled foliage. Large leaves, distinctly speckled with golden yellow. Should be speckled with golden yellow. Should be $\$ 2.50$ to $\$ 5.00$ each.

ABUTILON (Chinese Bell Tree). Best assorted varieties. $50 \mathrm{c}$ each.

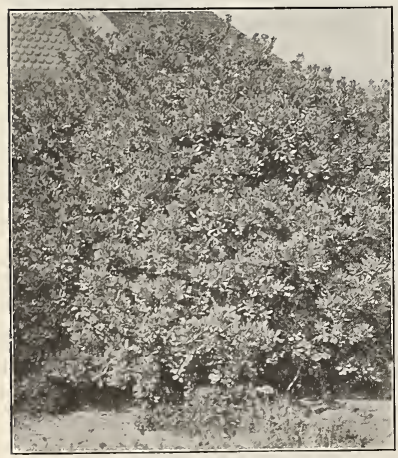

Pittosporum Eugenoides (See Page 50)

CALLISTEMONS (Bottle Brush). 5-inch pot plants, $50 \mathrm{c}$ eacb; 1 gallon cans, $75 \mathrm{c}$ each.
CHOISYA TERNATA. One of the choicest of shrubs on account of its shiny foliage and masses of pure white, orange scented flowers. One gallon cans, $75 \mathrm{c}$ each; 5 gallon cans, $\$ 2.50$.

COPROSMA BAUERI. A dense growing shrub with bluntly rounded flossy green leaves A fine decorative foliage plant and leaves. A finer for lawn decoration or as excellent either for lawn decoration or as single specimens and well adapted for borders. It also makes a fine compact hedge
or shrub. We can furnish either the green or variegated leaves. 1 gallon cans, $50 \mathrm{c}$; 5 gallon cans, $\$ 2.00$ each.

CRAPE MYRTLE. In white, pink or purple. 6-inch pots, $75 \mathrm{c}$ each. Large plants up to $\$ 1.50$.

CESTRUM PARQUI. An interesting tender shrub of easy cultivation with small greenish flowers of delicate fragrance, which is dispensed in the night only. Also called "Nigbt Blooming Jasmine." 5-inch pots, $50 \mathrm{c}$ each; 1 gallon cans, $\$ 1.00$ each.

CYPERUS ALTERNIFOLIUS (Umbrella Plant). 5-inch pot plants, 50c each.

CERATONIA SILIQUA. "St. John's Bread" or "Carob Tree." 40 feet. A thick growing tree with masses of dark green foliage. Will grow in any soil and thrives with scarcely any water. In gal. cans, 2 to 3 feet, each, $75 \mathrm{c}$.

CUPRESSUS LAWSONIANA. "Lawson's Cypress," 200 feet. One of the most strikin and horizontally spreading pendulous brancbes, and flat, compressed foliage; unsurpassed for specimens on lawns. Balled, 2 to 3 feet. Each, $\$ 2.50$.

ITALIAN CYPRESS. We have a good stock of these popular conifers, the true "Cupressus sempervivens semper pyramidlis," trees of extra compact narrow habit. One-yearold plants, 12 to 14 inches, in one gallon cans, 50c each. Field grown, well furnished with growth from the ground up, well balled and burlapped, $75 \mathrm{c}$ a foot.

CHOISYA TERNATA. A pretty shrub with bright green, deeply cut foliage and clusters of white, fragrant flowers. In gal. cans, each, $50 \mathrm{c}$.

CISTUS LADANIFERUS MACULATUS. "Spotted Rock Rose." A free flowering shrub of low spreading habit. Flowers 3 to 4 inches in diameter, pure white with crim4 inches in diameter, pure white with crim-
son spot at base of petals. In 4-inch pots. Ean spot at

CORONILLA GLAUCA. A small shrub with glaucous foliage and quantaties of with glaucous foliage and quantaties of
bright yellow pea shaped flowers. In gal. cans, each, $50 \mathrm{c}$.

COTONEASTER FRANCHETTI. A hand some shrub with many gracefully arching branches. Foliage of medium size, distinctly downy, Flowers pink followed by reddish yellow berries. In gal. cans, each, $75 \mathrm{c}$.

COTONEASTER ANGUSTIFOLA. A shrub of upright spreading habit, with small narrow foliage and covered with bright orange colored berries during winter. In gal, cans, each, $75 \mathrm{c}$.

COTONEASTER HORIZONTALIS. Of low, almost prostrate growth. Foliage small, turning red in winter. Berries brick red, produced in great quantities. In gal cans, each, $75 \mathrm{c}$.

CRATAEGUS CRENULATA. Similar to the preceding but has narrower leaves and bright red berries. In gal. cans, each $60 \mathrm{c}$. CRATAEGUS MICROPHYLLA. M u ch branched and almost prostrate. Small dark green glossy leaves, large red berries. Very handsome for rock work. In gal. cans, each, $75 \mathrm{c}$.

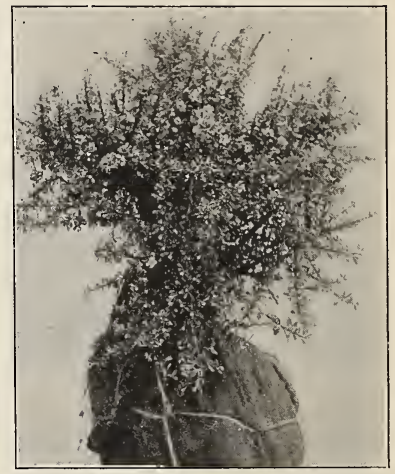

Cotoneaster Franchetti

CRATAEGUS PANOSA. Of spreading habit, with many gracefully drooping branches, grey green downy foliage; covered in fall grey green downy foliage; covered in fall berries. In gal. cans, each, 75c.

CRATAEGUS PYRACANTHA. "Evergreen Tha" "Burning Bush," 10 feet. A Thorn" or "Burning Bush, 10 feet. A thorny, thick growing evergreen shrub, folwhich are particularly attractive, remaining on the plant all winter. In gal. cans, each, $60 \mathrm{c}$.

CRATAEGUS YUNNANENSIS. A very desirable shrub lately introduced from Yunnan, China. It is of low spreading habit, many of the branches being perfectly prostrate. The foliage is rich dark green, and in fall and winter the plants are literally covered with brilliant scarlet berries. For covering banks this shrub probably has no equal. In gal. cans, each, $75 \mathrm{c}$.

DURANTA PLUMERI. "Golden Dew Drop." A beautiful shrub with light green foliage and large clusters of pale blue flowers, followed by bright yellow berries. In gal. cans, each, $75 \mathrm{c}$.

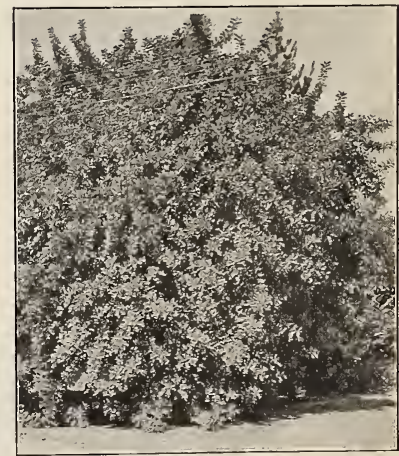

St. John's Bread 
CUPRESSUS ARIZONICA. "Arizona Bluc Cypress." 70 feet. A tree of great scenic value, and without doubt the most silvery of all cypresses. It grows quite rapidly and forins a perfect tree, thriving in almost any soil, standing intense heat and much frost. In gal. cans, each, $75 \mathrm{c}$.

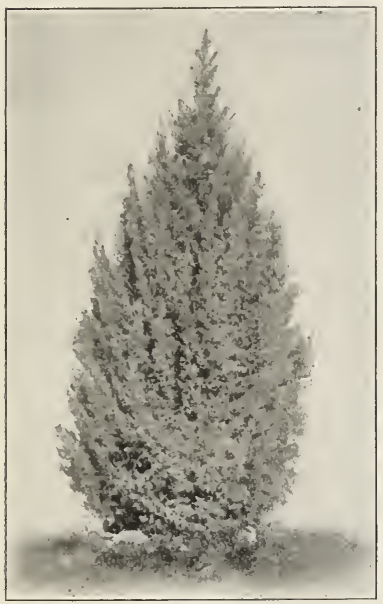

Arizona Cypress

DIOSMA FRAGANS (Breath of Heaven). 5 -inch pot plants, 50c each; 6-inch pots, $\$ 1.00$ each.

ESCALLONIA ALBA. 10 feet. A beautiful shrub of upright growth; leaves deep, glossy green; flowers pure white, in large terminal cymes, appearing abundantly in fall and early winter. In gal. cans, each $75 \mathrm{c}$

ESCALLONIA ROSEA. 10 feet. A very desirable kind, with conspicuous pink blossoms. In gal. cans, each, $75 \mathrm{c}$.

EUGENIA. We keep in stock the E. Myrtifolia, also called the Australian Brush Cherry, and another variety with larger leaves, called Eugenia Hookeri, both varileaves, called Eugenia Hookeri, both vari Southern California; they grow naturally Southern California; they grow naturally
into a shrub, shaping themselves into an al most perfect pyramid. Trimmed into a slim column they produce a much better effect than the Italian Cypress, as thy blend better with our California trees and shubs. As a tub plant for porch decoration they have no equal, their beautiful glossy green foliage producing a fine effect. 1 gal. cans, $75 \mathrm{c}$ each; 5 gal. cans, $\$ 3.50$ each; balled 5 to 6 feet, $\$ 7.00$ each.

EVONYMUS. An evergreen shrub in the silver or golden variegated or the green leaved varieties. In 3 -inch pot plants, $15 \mathrm{c}$ each; $\$ 1.25$ per dozen. Heavy clumps, balled from the open ground, $\$ 3.00$ each.

ELEAGNUS (Evergreen Oleaster). A highly ornamental shrub with handsome foliage. Good for lawns or as single specimens. Will do well in any ordinary soil and thrives remarkably well in interior valleys. In 12 -inch pots, $\$ 2.00$ each.

ERYTHRINA CHRISTI GALLI. Known as the Coral Tree. Produces enormous spikes of coral pea shaped flowers, one of the prettiest shrubs in California. 6-inch pot plants, $\$ 1.00$ each.

FUCHSIA. Double, white and blue, single varieties, in 3 -inch pots, $25 \mathrm{c}$ each; 5 -inch pots, 50c each.
GENISTA CANARIENSIS. Produces large quantities of yellow flowers in early spring. 5 -inch pot plants, $50 \mathrm{c}$ cach; 6-inch pot plants, $75 \mathrm{c}$ each.

GREVILLEA THELMANNIANA. D w a $f f$ red flowering variety of this well known specics. 5 -inch pot plants, $75 \mathrm{c}$ each; largc specics. 5 -inch pot plants, $75 \mathrm{c}$ each, 1 argc
specimen plants from open ground, $\$ 2.50$ specin.
each.

HAKIA LAURINA. A handsome shrub be longing to the bottle brush family. Flow ers open up around one stem, taking the shape of a bottle brush. Part of the flowers on this stem are white, and part red, which gives it a very striking appearance when in bloom. Plants in 5 gal. cans, 5 to 6 feet high, $\$ 2.50$ each.

HAKIA PICTINATA. (Also called Suavolens.) Flowers white, sweet scented ; young plants, 75 each; large plants, well established, 5 feet high, $\$ 2.50$ each.

HABROTHAMNUS OR CORAL PLANT. A strong growing shrub bearing panicles of small trumpet shaped purplish red flowers. Makes fine effect on lawn or for training against a porch or wall. 1 gal. can, $75 \mathrm{c}$ each.

HYPERICUM (The Gold Flower). Grows about 4 feet. Rounded compact habit, producing single yellow flowers of a satiny texture in great profusion during the summer. The numerous nodding branches are densely furnished with dark green ovate leaves. Very effective in massing and should be in every garden. Two feet high, 1 gal. can, $75 \mathrm{c}$ each.

HIBISCUS. All leading varieties, single and double; white, pink and yellow; 1 gal. can, $50 \mathrm{c}$ each.

HY DRANGEA. The leading white, pink and blue flowering varieties: 1 gal. cans, $50 \mathrm{c}$ each; 5 gal. cans, $\$ 2.50$ each.

HELIOTROPE. White, blue or dark blue, 5 -inch pot plants, $35 \mathrm{c}$ each; 1 gal. cans, $50 \mathrm{c}$ each.

LANTANA. Large assortment of all leading varieties. 5 -inch pot plants, $25 \mathrm{c}$ each.

LEMON VERBENA. 1 gal. cans, $75 \mathrm{c}$ each.

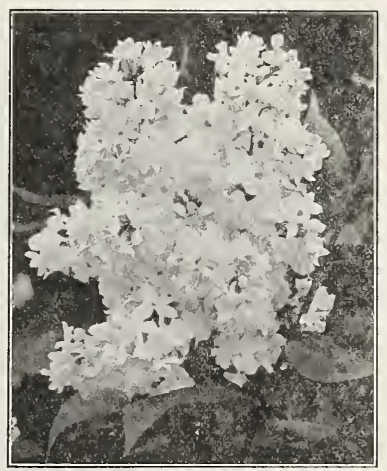

Lilac

LILAC. White or purple, 1 gal. cans, $75 \mathrm{c}$ each; 5 gal. cans, $\$ 2.00$ each.

LIGUSTRUM JAPONICUM (Japanese Privet). 20 feet. A large shrub or small tree, with glossy, dark green leathery leaves; often used for hedges and stands, trimming well. In flats of 100 plants, $\$ 3.50$.

L. LUCIDUM VARIEGATUM (Variegated Privet). ..Very similar to the preceding, but with variegated foliage. In gal. cans, each, $50 \mathrm{c}$.
L. NEPALENSE (Small leaved Privet). 10 feet. Much used for hedgcs in Southern California. It grows quickly and can be trimmed in any way desired, making a dense, thick hodge. Lcaves small, light green, flowcrs whitc, in large sprays. In flats of 100 plants, $\$ 3.50$.

LEPTOSPERMUM LAEVIGATUM. This beautiful slurub does particularly well in California and is very valuable for planting in masscs, and for filling up odd corners. It grows rapidly and in the spring is laden

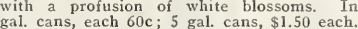

LONICERA NITIDA (Upright Evergreen Honeysuckle). A small shrub of recent introduction. It has very small foliage and white flowers followed by purple berries. Suitable for hedges or single specimens. In gal. cans, $50 \mathrm{c}$ each.

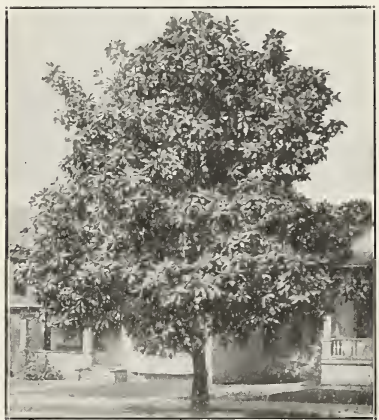

Magnolia Grandiflora

MAGNOLIA GRANDIFLORA. 80 feet. One of the finest of American evergreen trees. The leaves are thick, bright green and rusty on the under side. Flowers large, waxy white and fragrant. In 5 gal. cans, 4 to 5 feet high, $\$ 1.50$ each.

MELALEUCA. Four varieties. This plant is commonly known as the Bottle Brush from the shape of its flowers; they stand sea winds and alkali soil i gal, cans, sea winds

MYRTUS COMMUNIS (Common Myrtle). Handsome shrub of rather compact growth, with small, glossy green, aromatic leaves. Bears quantities of small, white, fragrant flowers. Valuable either for single plants or for a hedge. In 1 gal. cans, $50 \mathrm{c}$ each.

MEUHLENBECKIA PLATYCLADA. One of the hardiest of shrubs. The stems sometimes called leaves, are flat, giving the plant a peculiar appearance. 5-inch po plants, 50c each; large size, $\$ 1.00$ each.

MOCK ORANGE (Philadelphus). A vigorous shrub with large handsome foliage and with creamy white showy flowers in terminal racemes or solitary on short branches. Flowers very fragrant with odor of the orange blossom, hence the name. Well
adapted for shrubberies and will thrive in any well drained soil even under trees. $3 \mathrm{ft}$., $1 \mathrm{gal}$. cans, $75 \mathrm{c}$ each.

NANDINA DOMESTICA (Japanese Nandina). A very small shrub growing about 5 feet, but increasing by new stalks coming up from the root. The leaves are compound, divided into many small leaflets, a very graceful, rich red when young, dark green at maturity but taking on beautiful green at maturity but taking on beautiful coppery tones in winter. Flowers white in upright panicles followed by quantities of bright scarlet berries. This shrub thrives remarkably well in California, growing in full sun, shade or partial shade. It also cans, $\$ 1.00$ each. 


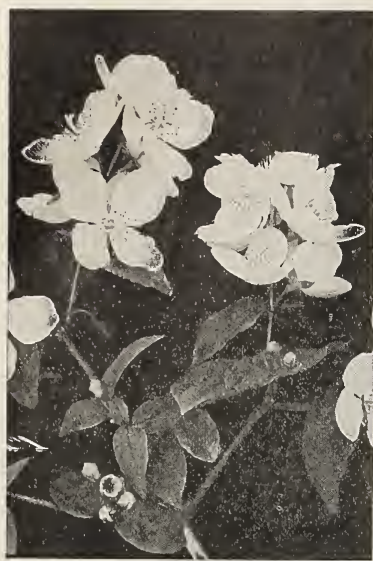

Mock Orange

MELIA AZEDARACH UMBRACULIFORMIS (Texas Umbrella Tree). A well known deciduous tree. The branches are erect and deciduous tree. The branches and in a manner radiating from the trunk and with drooping foliage, give it the appearance of a gigantic umbrella. It is a handsome shade tree and will stand a great
amount of heat. Bare roots, 4 to 6 feet, $\$ 1.00$ each.

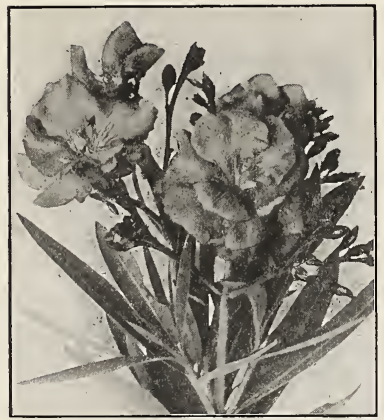

Oleander

OLEANDER. A well known and favorite shrub. Double pink and double white. In gal. cans, $75 \mathrm{c}$ each.

PINUS CANARIENSIS (Blue Pine). 80 feet. A beautiful tree with long pendant needles of a glaucous blue color. It is of rapid of a glaucous blue color. It is of rapid growth, stands drought well and is one of the best pines for Southern California. It has the peculiarity of sprouting from the stump when curled down or even burned off, which is a valuable feature in the reforesting of our mountains. In gal. cans, 2 to $3 \mathrm{ft}$., $60 \mathrm{c}$ each. Balled, 3 to $4 \mathrm{ft}$. $\$ 1.50$ each.

PITTOSPORUM EUGENIOIDES. 20 feet. A handsome shrub of upright growth with light green leaves and dark stems. Very pretty for hedges and also as single specimen plants. In gal. cans, $75 \mathrm{c}$ each.
PITTOSPORUM UNDULATUM. A handsome shrub; very hardy; stands the extremes of cold and heat. One of the few plants that close to the ocean. plants that will grow close to the ocean. Large plants thoroughly established, 1
cans, $75 \mathrm{c}$ each; 5 gal. can, $\$ 2.00$ each.

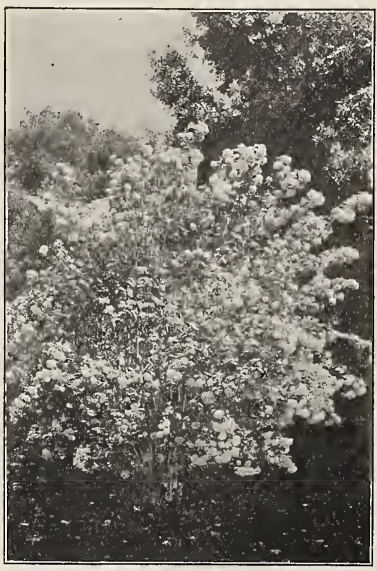

Snowball

POINSETTIA PULCHERRIMA (Los Angeles Christmas Flower). Plants in 6-inch pots, $75 \mathrm{c}$ each; 1 gal. cans, $\$ 1.00$ each.

PLUMBAGO. White or blue variety. $1 \mathrm{gal}$. can, $75 \mathrm{c}$ each.
RHAMNUS (California Coffee Tree). A very hardy shrub with oval elliptic, smooth, shining green leaves. Very small greenish flowers disposed on short racemes, 12 inches high, 6 inch pots, $\$ 1.00$ each.

SPIRAEA REEVESI (Bridal Wreath), $50 \mathrm{c}$ each.

SNOWBALL (Viburnum Opulus). Blooms abundantly in Southern California. Strong plants, $\$ 1.00$ each.

SWANSONIA ALBA. White, pea shaped flowers. 6-inch pot plants, $50 \mathrm{c}$ each.

STREPTOSOLEN JAMESONI. The Yellow Heliotrope. A very useful garden shrub producing masses of showy yellow flowers. 5 -inch pot, $50 \mathrm{c}$ each.

VERONICA. A showy free blooming plant. Succeeds in any good garden soil in a sunny location. Leaves a glossy green. The violet blue and the amaranth red varieties, in 4-inch pots, 25c each; 1 gal. cans, $\$ 1.00$ each.
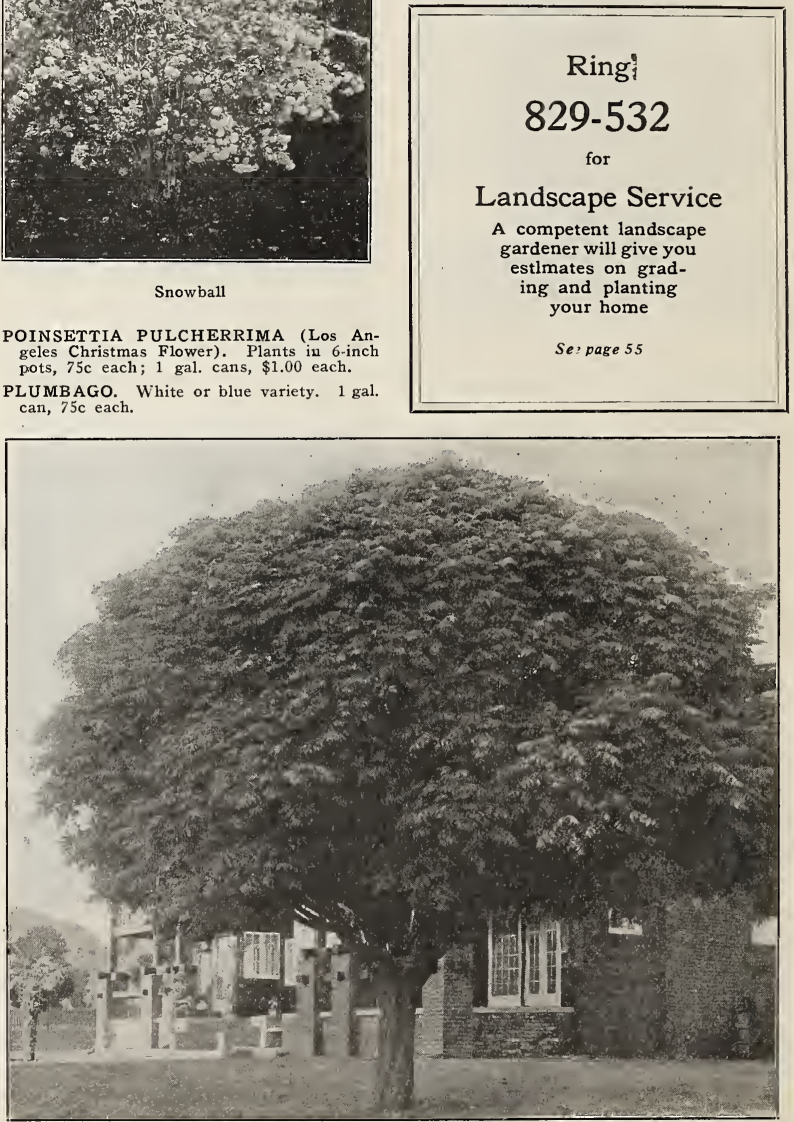

Texas Umbrella 


\section{Desirable Palms and Tropical Plants}

Unexcelled in Beauty and Grandeur

The elimate of Southern California has no equal in the world. It is the mildness of our climate and temperature that attracts thousands of visitors and new settlers from all over the world. Upon arriving here, those neweomers cxpect to see in the way of vegctation something entirely different from that to which they have becn aceustomed in the East or North.

There is one idea that should always be borne in mind when laving out gardens or parks in Southern California. It is the fact that tropical and scmi-tropical plants and trees must be used to as great an extent as the elinatic conditions will allow. Palms and plants with large foliage are the main factors in attaining this object. We advise those who intend laying out cither large or small gardens to consult landscape architcets who have been in California a number of years and who have made a study of the local conditions. Landscape arehitects who are neweomers to our part of the State are apt to reproduce scenery from Eastern or European parks, using quantities of deciduous and coniferous trees, which is a scrious mistake, and also a great disappointment to our visitors and neweomers.

I.et us make our gardens and parks "typical" of Southern California and a "demonstration" of her elimate and the richess of her soil.

The following consists of plants and trees that have proven themselves to be suitable for Southern California. We earry a large stock of these tropical and semi-tropical plants for gardens and jungles and invite intending purchasers to make thcir own selections at our nursery.

ARONDO DONAX, or Ribbon Grass. Foliage green striped with white; very effective. Clumps, 25c to $\$ 1.00$ each.

ARALIA SIEBOLDI. This is a first class house plant; very hardy and useful; dark foliage plants are needed in shady corners. In 5-inch pots, $\$ 1.00$ each.

ARALIA PAPYRIFERA (Rice Paper Plant) A very tropical looking sinall tree or shrub with very large, deeply lobed leaves. The upper side of the leaves are a light green and the under side is downy. Easily cul tivated and is so effective in a short time that it deserves to be generally planted. Plants in $5 \mathrm{gal}$. cans, 3 to $5 \mathrm{ft}$., $\$ 1.00 \mathrm{each}$.

ВАМВОО. Where a tropical effect is wanted in a garden, no plant is as useful as the Bamboo. We offer a few of the best varieties.

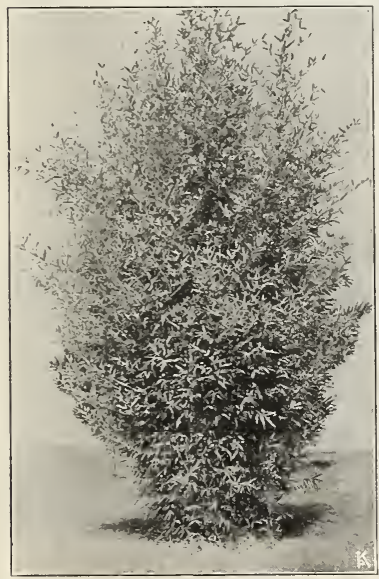

Bamboo

BAMBUSA VARIEGATED. Dwarf growing variety; leaves striped green and white, $\$ 1.00$ each.

BAMBUSA STRIATA. Another dwarf va riety with variegated foliage; very ornamental, $\$ 1.00$ each.

BAMBUSA KENEAHLIA. One of the dwarfest varieties of them all; foliage very fine and graceful, $\$ 1.00$ each.
GIANT BAMBOO. The giant of them all: producing enormous canes attaining a length of 50 feet and diameter at best 4 to 6 inches. Strong plants, $\$ 5.00$ each.

BAMBUSA NIGRA. Black wooded variety with very fine foliage, $\$ 1.00$ each.

BANANA, ABYSSINIAN (Musa Ensete). Large leaved Banana Tree, very ornamental and tropical looking. In 5 gal. cans, 4 to 5 feet high, $\$ 5.00$ each.

CANNAS. See Bulb List.

CALADIUM (Elephant's Ear). Plants with enormous leaves growing luxuriantly in very moist locations during the summer months. Bulbs, $15 \mathrm{c}$ each; 2 for $25 \mathrm{c}$. Plants started in pots, $25 \mathrm{c}$ each. Clumps with 3 or 4 crowns, $50 \mathrm{c}$ each.

COCOS AUSTRALIS. One of the most beautiful of all Palms for planting out either as specimen plants on the lawn or to be used for decorating verandas and porches. It is perfectly hardy all over Southern California. It is not unlike the Kentia Belmoreana, the leaves having the same curve. It is a beautiful bluish green, the leaves being much closer together than the Kentia. It will stand more hardships than any other plant used for decorating. This palm has been scarce and high priced for a number of years. A year ago we secured a quantity of these palms and now have them thoroughly established, so that these plants can be delivered at any time from now on, and our customers may be from now on, and our customers may be tion. We have plants in 12 -incb tubs from $\$ 2.50$ to $\$ 3.00$. These plants are about 2 feet high. Plants in 24-inch tubs, 3 to 5 feet high, will average from $\$ 3.00$ to $\$ 6.00$ each.

COCOS PLUMOSA. This paln is today considered the leading palm for avenue and street planting. The people of Southern just beginning to appreciate this most beautiful palm. It has been used very extensively in Santa Barbara and San Diego wbich gives these cities a very tropical appearance. Judging from the result cal appearance. palin that can compare with the Cocos palin that can compare with the Cocos nues and parkways. A movement is now on foot to line the wbole of Wilshire Boulevard in Los Angeles witb this noble palm, and even at the present time the parkings of some of our best residences are parkings of some of our best residences are Cocos Plumosa.

We have no small specimens to offer as we grow tbese palms in the open ground at our Montebello Nurseries until they are four years old and before we deliver them four years old, and before we deliver them tom heat or in tubs. The samples we have tom heat or in tubs. The samples we have Streets, are in 16 -inch tubs and thoroughly established. When transplanted they will not turn yellow nor lose their leaves. Prices on application.

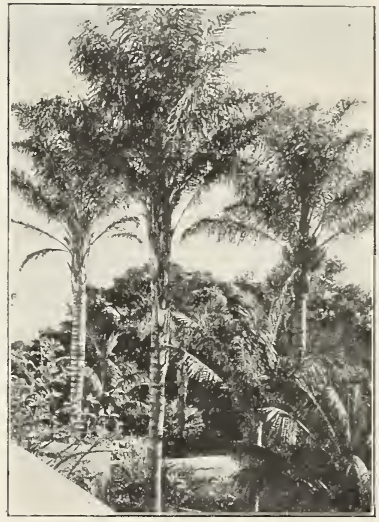

Cocos Plumosa

CHAMAEROPS EXCELSA (Chinese Fan Palm). Dark green foliage and leaves growing very close to the stem and trunk always covered with fibre; very hardy, or namental plants. Filed grown plants. Prices on application.

CHAMAEROPS HUMILIS. A dwarf variety of the above, sending small runners from the base; suitable for small corner or vases. $\$ 2.50$ each.

CYCAS REVOLUTA (Sago Palm). Fine ornamental plant, well known around South ern California. Perfectly hardy and easily grown in the bouse or garden. $\$ 2.50$ each.

CYPERUS ALTERNIFOLIUS (Umbrella plant). In 5 and 6 -inch pots, $25 \mathrm{c}$ and $35 \mathrm{c}$ each.

CYPERUS PAPYRUS, or the ancient "Bulrush." Plants in 1 gal. cans, 50c each. Clumps in 5 gal. cans, $\$ 1.00$ each.

DRACAENA AUSTRALIS. A large, wide leaved variety; a native of New England Very bardy and makes a first class house plant as well as outdoor plant. We bave a fine stock of these plants to offer at ex tremely low prices. $2 \frac{1}{2}$ to 4 feet high, $\$ 5.00$ each.

ERYTHEA EDULIS (Guadalupe). Trunk slender, sometimes as high as 30 feet; leaves resemble the California Fan Palm, but of a brighter green all the year round, bearing fruits in great profusion; these fruits are edible. Price, $\$ 1.50$ to $\$ 5.00$ each. 


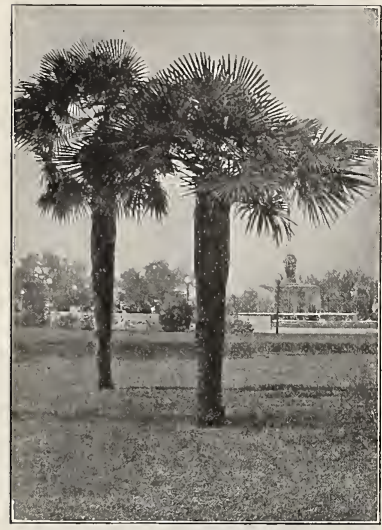

Chamaerops Excelsa

EULALIA JAPONICA. Ornamental grass, very graceful for massing together with other tropical looking plants, and will take any amount of water. Price, $75 \mathrm{c}$ each.

FICUS ELASTICA (India Rubber Plant). Very popular foliage plant for inside or outside decoration. Retains its bright, at tractive appearance even when neglected. Leaves large, dark green and shining on the upper side and a yellowish green on the under side. 6 -inch pot plants, $\$ 2.50$ each.

G Y N E R I U M ARGENTEUM (Pampas Grass). Clumps, $\$ 1.00$ each.

KENTIA BELMOREANA. Splendid house plant, a little tender for outdoor planting. Plants in 5-inch pots, about 1 foot high, $\$ 1.00$ each; 2 to 3 feet high, $\$ 2.50$ to $\$ 4.00$ each.

KENTIA FOSTERINIA. Resembling the above, leaves finer, price same.

PHORMIUM TENAX. New Zealand Flax Long swordlike leaves, striped with yellow and green. $\$ 1.00$ each.
PHOENIX RECLINATA Dwarf Date Palm. 12 to 20 feet. Very graceful, drooping leaves. Very handsome for avenue or lawn use. In 12 and 14 -inch tubs, 2 feet high, $\$ 2.00$ each.
YUCCA PENDULA Fine decorative plant especially adapted for planting in vase and window boxes that are exposed to the hot sun all day. Strong plants in 1 gal. cans, $\$ 1.00$ each; 5 gal. cans, $\$ 2.50$ each.

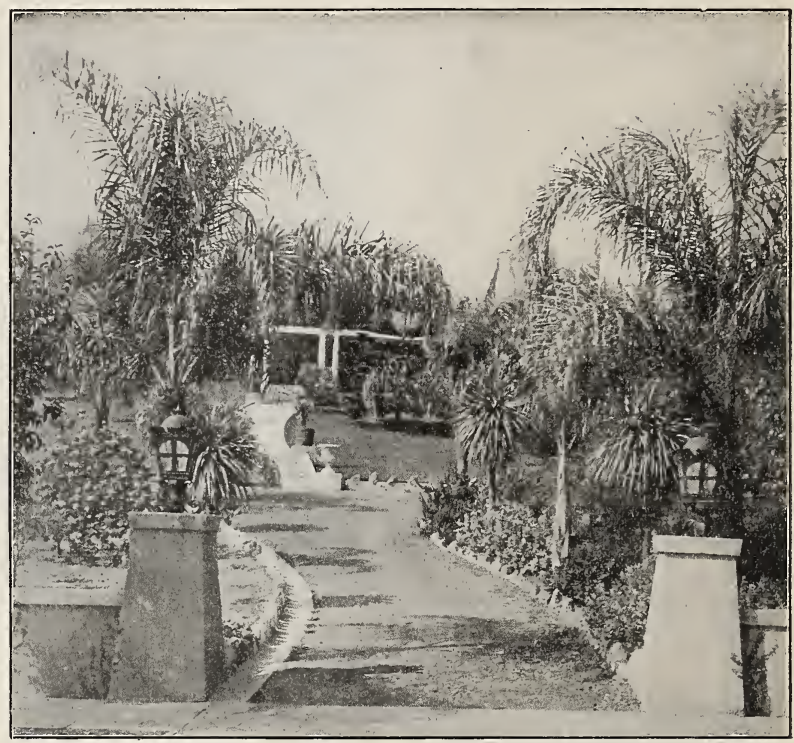

A Well Planted Tropical Garden

PHOENIX CANARIENSIS. The most popular and widely planted of all palms in Southern California, It is called the Canary Island Date Palm. We have a large stock of these palms and they are especially low priced. Plants in 1 gal. cans, $75 \mathrm{c}$ each; i large cans and boxes $\$ 2.50$ to $\$ 5.00$ each

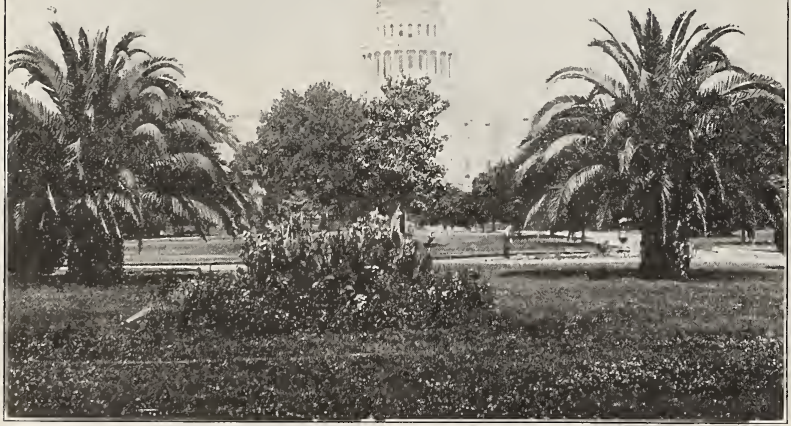

Phoenix Canariensis at State Capitol
PHOENIX DACTYLIFERA. Date of commerce, $\$ 1.00$ each.

STRELITZIA REGINAE. Resembling the Bird of Paradise of South America. Leaves glaucous, flowers very large, white and pink. Write for price.

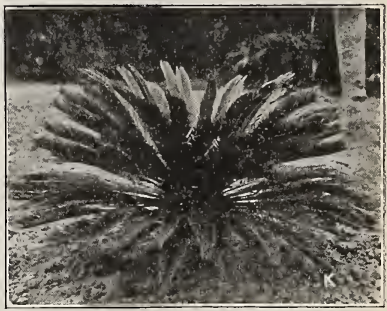

Cycas Revoluta, Sago Palm

SEAFORTHIA ELEGANS. A very attrac tive palm, making slender trunk, whitish and smooth, growing as high as 50 feet; leaves feathery, resembling a little the Date Palm. This palm is perfectly hardy in Southern California, very suitable for sidewalk planting. Large plants, $1 \$ .50$ and $\$ 5$ WASHINGTON FILIFERA (California Fan Palm). Balled or 5 gal. cans, $\$ 1.50$ to $\$ 2.50$ each.

WASHINGTONIA ROBUSTA. Balled or 5 gal. cans, $\$ 1.50$ to $\$ 2.50$ each. 


\section{Ornamental and Shade Trees of Known Merit}

\section{for Street and Parkway Planting}

The planting of shade trees along the roadside is a matter of great importance. The future growth of the trec should be the principal matter of consideration. Narrow streets should be planted with trecs that do not attain very great size, such as Acacia, Camphor, etc., while wid e thoroughfares should be lined with trees that attain large proportions, such as the Eucalyptus, Rubber, Redwood, etc. It must also be remembered that these trees are to remain where they are planted for many years, and that the proper preparation of the soil at the time of planting will be the prevention of many objectionable features in the years to come.

To begin with, the holes should be four feet deep and three feet wide. The soil from the surface should then be put into the bottom of the hole, and the poor soil which has becn dug from the bottom should be used on top. This is done to give the roots a chance to find their way down to the good soil, and will prevent them from growing under cement walks and curbings and lifting them up. If closcly observed, it will be found that the roots of the trecs will be attracted by conditions that are most favorable. They will grow toward the place where they find loose soil and fertilizer and moisture, hence the object of putting the richness directly beneath the roots in the bottom of the hole. This will prevent sidewalks from being ruined, as the roots will make no attempt to grow under them.

Below is a list of the shade and ornamental trees that are best suited to our climate.

ACACIA BAILEYANA. This is a strikingly heautiful moderate growing tree with glaucous green pinnated foliage and covered in the spring with racemes of lemon yellow flowers which completely envelop the tree. fowers which completely envelop the tree. Quite hardy, a magnificent specimen or avenue tree, hlooming earlier than any other
Acacia. Good for street when parking is narrow. In 5 gal. cans, $\$ 1.50$ each.

ACACIA DECURRENS (Green Wattle). This rapid and erect growing tree is one of the hest of the feathery foliaged varieties for park or avenue purposes. Brancheties for park or avenue purposes. Branch-
lets with very prominent angles and decurrent from the petioles; leaves feathery, very deep dark green. Flowers whitish yellow. 4 to $6 \mathrm{ft}$, 5 gal. cans, $\$ 1.50$ each.

ACACIA FLORIBUNDA. A rapid growing tree with a pendulous hahit, and with long narrow leaves; flowers in racemes hright yellow. Useful as a street tree. A profuse bloomer. In 1 gal. cans, $\$ 1.00 ; 5$ gal. cans, $\$ 2.00$ each.

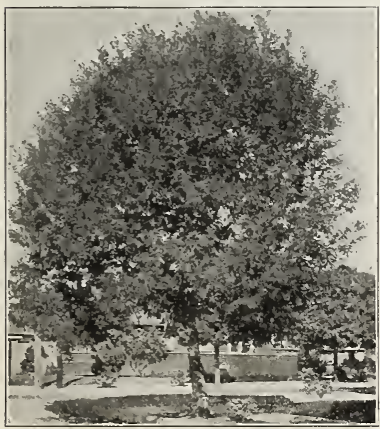

Acacia Melanoxylon

ACACIA MELANOXYLON (Black Wattle). A strong, upright growing tree; the leading variety for street planting. 4 to 6 feet, 5 gal. cans, $\$ 2.50$ each.

ACACIA PYCNANTHA (Golden Wattle). Of rapid growth; leaves long and narrow flowers fragrant, brilliant yellow, coming in long pendulous clusters. 1 gal. cans, $\$ 1.00$ each; 5 gal. cans, $\$ 2.50$ each.

ARAUCARIAS. See "Decorative Plants."

CRYPTOMERIA JAPONICA (Japanese Cedar). Large, elongated pyramidal tree, with straight, slender, tapering trunk, covered straight, slender, tapering trunk, covered upward spreading branches; branchlets very numerous, usually alternate. Bright green. Cones reddish brown, an inch or less in length. $\$ 1.00$ each.

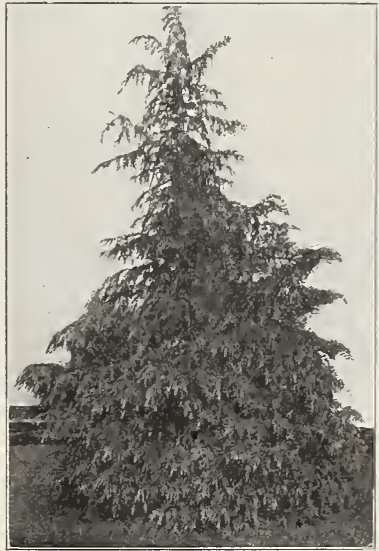

Cedrus Deodara

CAMPHORA OFFICINALIS ( $\mathrm{C}$ a $\mathrm{mpho}$ Tree). A rank growing, very symmetrical, ornamental tree, thriving in a poor soil, bright green foliage and well adapted for the lawn, street or avenue planting. To prepare the Camphor for commerce, the root, trunk and branches are broken up and treated with water in closed vessels, the treated with water in closed vessels, the rice straw. No garden is complete without rice straw. No garden is complete without
it. 1 gal. can, $\$ 1.00$ each; 5 gal. can, $\$ 2.50$ each.

CEDRUS DEODARA. Sacred Cedar of the Himalayas or Indian Cedar. Exceedingly handsome, with drooping hranches and silvery green foliage, forming a dense net. work; the finest and most rapid growing of all cedars, and worthy of a place in every garden. 3 to 4 feet, fully established, $\$ 4$ each.

CRAPE MYRTLE. See "Shrubhery and Ornamental Plants.'

CRYPTOMERIA JAPONICA ELEGANS (Elegant Japanese Cedar). Low, dense tree (rith with horizontal branches and pendulous texture, autumnal color bronzy crimson, which is retained throughout the winter. $\$ 1.00$ each.

CUPRESSUS LAWSONIANA. Beautiful Cypress with flat foliage. Balled, $\$ 1.50$ to $\$ 5.00$ each.
CUPRESSUS GUADALUPENSIS (Blue $\mathrm{Cy}$ press). Branches spreading and very conspicuous; on account of its coloring, it lends a charming effect when planted among other trees. Does very well throughout California and is always attractive. \$1.00 each in gal. cans; larger plants from the field, $\$ 3.50$ each.

CUPRESSUS MACROCARPA (Monterey Cypress). A native of California and one of the most desirahle evergreens. In old age, it becomes very picturesque, forming a broad flat topped crown. Foliage greyish green; stands pruning well and used extensively for hedges. It is a splendid tree for planting near the ocean. The Monterey Cypress is the best tree we have for a wind break. In flats of 100 plants, $\$ 2.50$ per flat. In pots, $25 \mathrm{c}$ each, $\$ 2.00$ per dozen,

EUCALYPTUS FICIFOLIA. Scarlet flowering. A most striking variety of dwarfish habit, with very dark green leaves and producing large panicles of brilliant scarlet flowers; one of the most ornamental and effective trees among the Eucalyptus; very tive trees among the Eucalyptus; very desirahle for small gar
large plants, $\$ 1.50$ each.

EUCALYPTUS ROBUSTA (Swamp Mahogany Gum). Well adapted to low ground, and also to the driest locations; very symsymmetrical while young; quite hrittle as it grows older; branches direct opposite in regular whorls; foliage large, of a deep glossy green color; flowers large, creamy white; hlooms late in the fall; very much prized by apiarists. $50 \mathrm{c}$ each. In flats of 100 plants, write for prices.

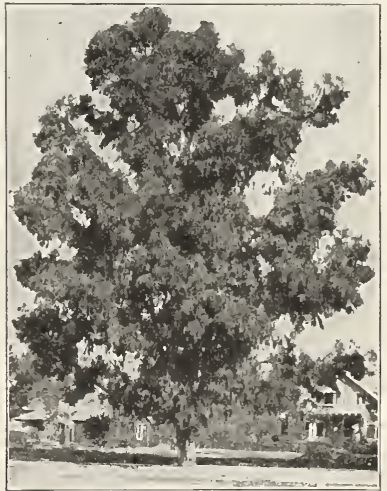

Eucalyptus Globulus 
EUCALYPTUS CORYNOCALYX (Sugar Gum). Very beautiful grower. Leaves distinctly rounded when young, but which in later years become acute lanceolate. It is readily recognized by its bright and shing leaves, which have the appearance of being
varnished. Its timber is durable and used for railroad ties, posts and other underfor railroad ties, posts and other under-
ground situations. A grand avenue tree. $50 \mathrm{c}$ each. In flats of 100 plants, market price.

EUCALYPTUS GLOBULUS (Blue Gum). Derives its name from its broad, bluish leaves, which it retains until three years of age, when it changes its character entirely, its leaves becoming of a reddish cast, lanceolate and thick. Has been more exten. sively planted than any other variety and is worthy of holding a leading place in all groves. The wood partakes of a very high polish, resembling hickory when finished. Its value for wagon work, bridge building, tool handles, insulator pins, and as firewood flats of 100 plants, write for price.

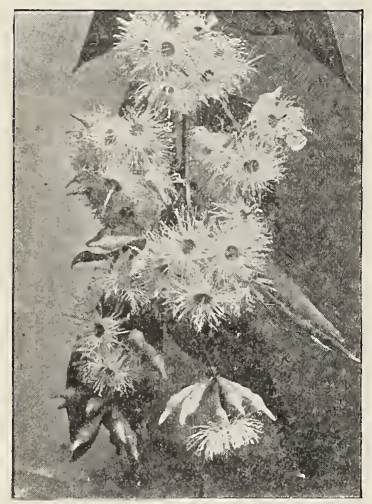

Eucalyptus Ficifolia

EUCALYPTUS ROSTRATA (Red Gum). Sends up a strong, straight leader and is a remarkably rapid grower, and in interior valleys is not exceeded even by the Blue Gum in its growth. The wood takes on an exceptionally high polish, is well adapted to interior finish and is recognized by the trade name of "Red Mahogany." The durability of its timber makes it exceedingly bility of its timber makes it exceedingly pots, $25 \mathrm{c}$ each, In flats of 100 plants, write for price.

FICUS MACROPHYLLA (Rubber Tree). Fine, large compact tree. One of the grandest of all decorative and avenue trees. $\$ 1.00$ to $\$ 5.00 \mathrm{each}$.

GREVILLEA ROBUSTA (Australian Silk Oak). A very graceful ferny leaved tree of rapid growth, covered in the early summer months with large golden yellow combs of flowers and very attractive to honey sucking birds and bees. Does well in all parts of California and is one of the most stately of avenue and lawn trees in the interior. When young, from two to five feet high, it makes a graceful subject for feet high, it makes a graceful
house decoration. $\$ 1.00$ each.

JACARANDA MIMOSAEFOLIA. A most beautiful symmetrical tree with foliage as finely cut as a fern; flowers blue or violet, showy terminal panicles, appearing in the early summer months. A favorite street tree in Southern California. Should not be planted in localities subject to severe frosts. $75 \mathrm{c}$ each.

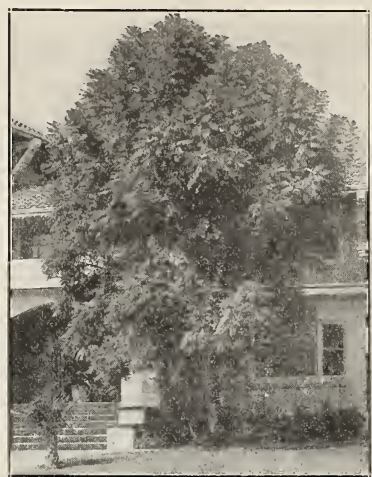

Jacaranda

LIVE OAK. This is the well known, majestic evergreen California Live Oak, 3 to 4 feet, 1 gal. cans, $\$ 1.50$ each. Large specimen, prices on application.

MAGNOLIA GRANDIFLORA. The most noble of American evergreen trees; foliage is thick, brilliant green on the upper surface and rusty beneath; the flowers are pure waxy white, of immense size and very fragrant. Nice specimen plants, 5 to 6 feet high, in 5 gal. cans, $\$ 1.50$ each.

PALMS. A great many Palms are suitable for shade trees, among them our native Fan Palm, Cocos Plumosa, Washingtonia Robusta, Dracaenas, Erytheas, Chamaerops, Washingtonia Filifera and Seaforthia. A description of all of these will be found under the head of "Plants for Tropical Gardens and Jungles."

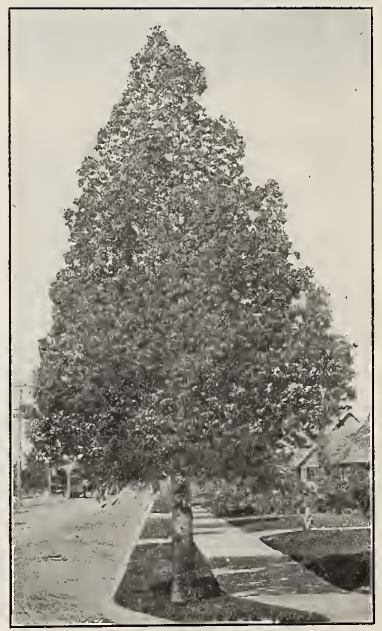

Sterculia Diversifolia
PEPOER TREE (Schinus molle) This ornamental tree has been one of the greatest attractions of Southern California, and justly so, for it is one of our most graceful and picturesque avenue, park or specimen trees. Its pendulous branches, feathery by blossoms, followed by red berries half the size of peas, present a series of combinations causing this tree to be one of the most popular ornamental trees of California. 2 to 5 feet, $50 \mathrm{c}$ each; 5 to $6 \mathrm{feet}, 75 \mathrm{c}$ to $\$ 1.00$ each.

SEQUOIA GIGANTEA (California Redwood). Attains a height of 300 feet. A magnificent avenue, park or specimen tree, rising like a tapering pyramid, the lower branches sweeping the ground. Foliage a bluish green completely covered with branchlets. Cones 2 to $21 / 2$ inches long. branchlets. Cons 2 to $2 \% / 2$ inches long. An excellent ornanental tree either for the coast or interior. 1 gal. cans, $\$ 1.50$ each;
specimen from the field from $\$ 2.50$ to $\$ 10.00$ specin
each.

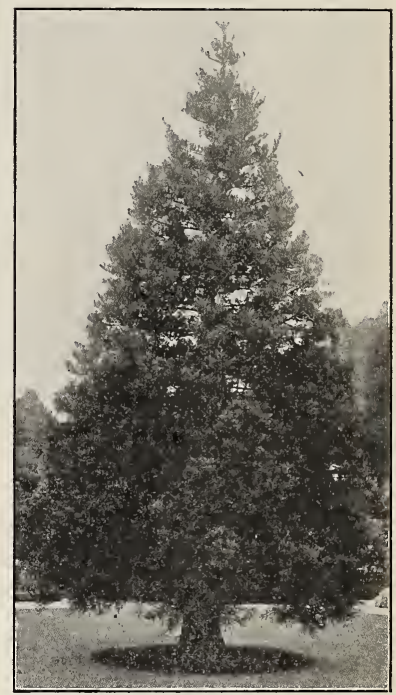

Sequoia Gigantea

STERCULIA DIVERSIFOLIA (Victoria Bottle Tree). This magnificent street and avenue tree, as its effective and ornamental qualities are becoming established, continues to be in great demand. One great point in its favor is that its roots do not point in with the pavements in city streets interfere with the pavements in city streets graceful tapering habit of trunk and foliage gives it a supremacy over many other trees. Its foliage, which is bright, glossy green, is constantly changing in shape, sometimes ovate, then ovate-lanceolate, and again 3 to 5 lobed on the same tree. 2 to 3 feet, $75 \mathrm{c}$ each. Field grown, 2 years old, established, $\$ 2.00$ to $\$ 3.50$ each.

ST. JOHN'S BREAD (Ceratonia). A handsome shaped tree, with round spreading top and small glossy green leaves bearing edible pods. Plants in 1 gal. cans, $\$ 1.00$ each; large plants, $6 \mathrm{ft}$. and over, $\$ 1.50$ to $\$ 3.00$.

UMBRELLA TREE (Texas Umbrella). Plants in 1 gal. can, $\$ 1.50$ each. Plants 


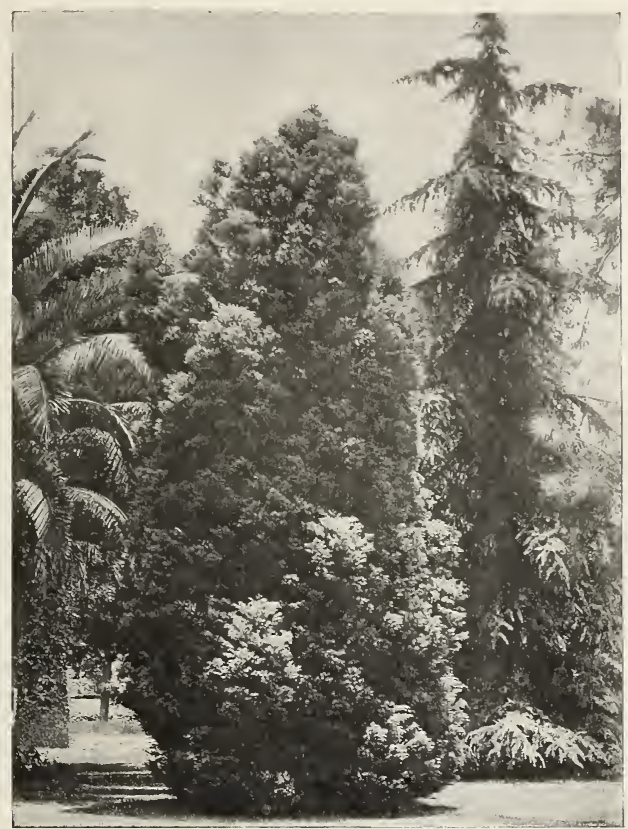

\section{OUR LANDSCAPE DEPARTMENT}

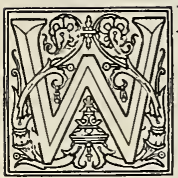

E desire to call especial attention to our Landscape Department. During our long residence here we have applied ourselves to the study of the native vegetation of Southern California-the soils and climate-and are quite familiar with the different localities in this end of the State. Our hill districts abound in beautiful canyons and the valleys are incomparable for richness of soil and climate, enabling a variety of planting, both summer and winter, possible only in this one spot of all the world.

Let us carefully select the trees and shrubbery for your home in Southern California. Some locations have a native undergrowth and it is here that judgement should be used to obtain harmonious effects. In the valleys, with practically bare ground, pleasing effects are obtained by careful selection and proper planting.

We offer you the benefit of our thirty-five years study and experience in Southern California at a very reasonable cost. 


\section{Treatment of Insects and Diseases in the Garden and Orchard}

\section{High quality fruits and flowers are borne on clean trees and plants See next page}

\section{Citrus}

BLACK, YELLOW. PURPLE AND CITROLA SCALE. 1 pound rosin spray to 3 gallons of water.

MEALY BUG. 1 part "Canco" to 50 parts water.

REDSPIDER. Calyspray No. 81 .

\section{Apple}

SCAB. Spray with Blanchard's lime sulphur, 1 gal. to 40 gal. water, when blossoms show pink; 2nd spraying when blossoms are falling; 3 rd spraying 3 weeks later.

\section{Pear}

PEAR PYSLIA. Blanchard's lime sulphur, 1 gal. to 7 gal. of water, just before the blossoms separate to cluster, to kill the eggs.

PEAR SCAB. Spray with 1 gal lime sulphur to 50 gal water.

\section{Plum}

BROWN ROT. Lime sulphur $1 \mathrm{gal}$ to $50 \mathrm{gal}$. water, just before the fruit begins to ripen. SCALE. 1 part "Canco" to 50 parts water.

\section{Peach}

LEAF CURL. 1 gal. lime sulphur to 8 gal. water before the buds begin to swell.

SAN JOSE SCALE. Spray while trees are dormant with lime sulphur, 1 gal. to 8 gal. of water.

\section{Cherry}

BROWN ROT. Lime sulphur, 1 gal. to 50 gal. of water, just before the fruit begins to ripen.

\section{Rose Bushes}

MILDEW OR CURLY LEAF. Dust with Calyspray No. 1 (Nicotine Sulphur).

SCALE ON ROSES. Spray with Mapco nicotine spray (nicotine and pine-oil), $3 \mathrm{oz}$. to 1 gal. water.

\section{Shrubbery in General}

APHIS AND BLACK SCALE. Use same as for roses.

BROWN SCALE, Yellow, Purple Scale, Mealy Bug or Red Spider. Use 1 part of "Canco" to 50 parts of water.

\section{House Plants}

FERNS, Aspidistra, Kentia, Ficus and similar plants, use 3 oz. "Mapco" (Nicotine spray) to one gal. water.

\section{Vegetables}

SQUASH BUGS, BEETLES, ETC. on Melons, Cucumbers, Tomatoes and Squash Dust with Calyspray No. 81 (nicotine and lead arsenate).

APHIS on Cabbage, Kale, Lettuce. Spray Mapco, 3 oz. to 1 gal, water, or dust with Nico-Dust.

CUT WORMS on vegetables and plants in general, mis one pound of Paris Green to 10 pounds bran; mix well and scatter all over ground.

GRASS HOPPERS can be kept off by the same remedy.

VEGETABLE AND FLOWERING PEAS, GREEN BEANS AND WINDSOR BEANS should be dusted with Calyspray No. 1 (nicotine sulphur) as soon as they are 6 inches out of the ground; a second dusting when they begin to blossom.

\section{Miscellaneous}

SOW BUGS. One pound of Rye fiour, one teaspoonful Paris Green, two teaspoonsful of sugar. Mix thoroughly and place on a board among plants. Replace often.

MEALY BUG. Use Canco 1 part to 50 parts water.

SNAILS. Use Hammond's Slug Shot freely ; dust it over the plants and over the surface of soil which should be kept dry for a few days.

ANTS. Use El Roy Argentine Ant Poison. FLIES. Use Nomore-Fly. For cattle, in dwellings, restaurants, bakeries, etc.

CHICKEN LICE. Spray the houses with Dr. Hess's or Dr. La Gear's preparations. Dust the hens with Dr. Hess's Louse Killer. GOPHERS. El Roy Gopher Poison.

GROUND SQUIRRELS. Gas balls will help you to get rid of these pests.

MOLES. No use to try poison; a mole eats insects only. Use the Rittenhouse mole trap.

DIRECTIONS FOR POISONING RABBITS. Gather 5 pounds of fresh green alfalfa from the field late in the afternoon. The most tender tips should be securred and cut into lengths of 2 to 4 inches. In the evening place small handfuls of the alfalfa in the rabbit trails leading to fields which are being damaged. For cottontails, the baits may be placed near the fields or at points where they are going under a netting fence. For jacks the baits should be placed in the trails from 50 the 100 yards or more away from the green fields 100 yards or more away from the green fields
where they have been feeding. For jackrabbits repeat this rebaiting treatment for several nights. For cottontails one night's pre-baiting is sufficient. By doing this you not only get the rabbits used to finding the feed in the trails but it will also give you an indication as to where to place your poisoned baits.

After you have determined where to put the poison and you have the rabbits in the habit of eating the unpoisoned baits you should prepare the poisoned baits as follows: Gather 5 more pounds of fresh green tender alfalfa 5 more pounds of fresh green tender alfalfa
tips and spread it out on a newspaper or tips and spread it out on a newspaper or ounce of powdered alkaloid strychnine dusted on dry from a shaker can. MIX THOROUGHLY. Place small handfuls of these baits at points in the trails where rabbits took the unpoisoned baits on the previous nights. Near nights. standard poisoned grain so that the kangaroo rats, sqirrels, etc., will eat the grain baits and leave the alfalfa baits for the rabbits.

-U. S. Biological Survey.

WARNING.-Do not place the poisoned alfalfa within reach of livestock.

\section{Tree Doctoring}

GUM DISEASES. Bordeaux Mixture should be applied with brush to affected parts, and the whole tree sprayed with same solution.

TREE BORERS. Dig out the borer, disinfect with solution of Bordeaux Mixture, and cut the tree back severely.

HOLLOW TREES. Some of our oldest live oaks, covered with beautiful green tops, are hollowed out at the base and expose to the elements the most vital parts, and the very base of the trunk is slowly disintegrating. To lengthen the life of these trees it is necessary to close up these cavities and proceed as follows:

First scrape out carefully all soft and dead wood from inside the cavity. Second, paint the scraped surface with asphalt paint. Third, fill the cavity with concrete.

Same can be applied to all other varieties of trees.

NOTE.-In cutting large branches and after doing heavy pruning in cases where trees are bruised or barked, use ShermanWilliams Pruning Compound.

The extermination of insects and other parasites concerns the whole community as well as the individual, for if one place is infected it does not take long to spread over a whole locality.

It should be not only a matter of private interest, but of civic pride for owners of gardens and orchards to see that insect pests and diseases are eliminated. This can be done by seeing that the proper persons are occupying the positions of horticultural commissioners in your locality; and when you have competent officials like we have in Los Angeles County today they should be given your whole hearted support in the performance of their duties.

The above list of treatments for diseases of plants and trees has been submitted to the Horticultural Commissioners of Los Angeles County. Any cases not provided for in this list, we will be glad to take up with the proper authorities in each individual instance for correct treatment. 


\section{INSECTICIDES AND FUNGICIDES}

HAMMOND'S SLUG SHOT INSECTICIDE. This preparation though injurious to insects does not injure the foliage and acts in some measure as a fungicide. It destroys all insects injurious to house and garden plants, shrubs, trees, vines, potatoes, melons, cabbage, currants, vegetables and fruits of all kinds. Dust the powder lightly over the infected plants so as to cover every part of them. One application is generally suficient, but if a new brood appears repeat the operation at once. Sold out of bulk at the rate of $15 \mathrm{c}$ per pound.

HAMMOND'S SLUG SHOT, especially mixed for use in poultry yards. This mixture is one of the most reliable, and one of the finest put up. It can be used safely on small chicks, and can be used right in the brooder and incubator. Put up in cartons with perforated tops, so that no bellows or powder gun is needed. The powder is released through the perforated top by pressing the sides of the carton. Price, $25 \mathrm{c}$ each.

TOBACCO DUST. For green fly. Per 1b., $15 \mathrm{c}$.

NICOTINE SULPHATE. Destroys plant lice of all kinds, red spiders, aphis and sheep ticks. $1 \mathrm{oz}$. bottle will make 5 gal lons of solution, $35 \mathrm{c} ; 1 / 2 \mathrm{lb}$. cans make 40 gallons of solution, $\$ 1.25$.
SULPHUR. For mildew on roses, etc. Per lb., 10c; 3 lbs., 25c. California Sulphur, re-sublimated Sulphur, per 100 lbs.

PHENOLENE, for spraying chicken houses. Small bottle, $35 \mathrm{c}$; large bottle, $60 \mathrm{c}$

BORDEAUX MIXTURE IN POWDER. We sell this article in bulk at the rate of $50 \mathrm{c}$ per pound. Ten pounds make a 50 . gallon barrel of spray when liquid is desired. Bordeaux Powder can be dusted on the plants or blown on with a powder gun or bellows.

HELLEBORE, For killing Caterpillars and army worms, 1/4 lb. box, 25c; largez size, $50 \mathrm{c}$.

LIME SULPHUR SOLUTION. An indispensable spray for your fruit trees in the spring. To prevent mildew, disease and curly leaf. Qts., $40 \mathrm{c}$; $1 / 2 \mathrm{gal} ., 75 \mathrm{c}$

CANCO. A valuable liquid diluted 1 to 50 with water will destroy all insect pests in the ground. Will also destroy aphis and plant lice. It also is valuable as a spray for the chicken houses. Price, pints, 50c; qts., $75 \mathrm{c} ; \mathrm{I} / 2$ gal., $\$ 1.25$; gal., $\$ 2.00$.

FLY KILLERS. Dr. Hess' or Dr. LeGear's. Both priced at the uniform price of $75 \mathrm{c}$ per $\mathrm{I} / 4 \mathrm{gal}$.
NO MOR FLY. A Los Angeles product whicl has given entire satisfaction during the whole summer season for killing flies, cockroaches, moths and all kinds of house pests. This insect destroyer is mixed witl agreeable scented extracts which makes it very suitable for using in the dwelling, bakeries, groceries, markets, etc. Qts. $\$ 1.25$;

WHALE OIL SOAP. One of the old stand bys for destroying scale on citrus trees and shrubbery. $1 \mathrm{lb}$. cans, $35 \mathrm{c}$.

ROSIN SOAP. Recommended by the Horti cultural Commission for the destruction of citrola, brown and black scale. $1 \mathrm{lb}$. cans, $30 \mathrm{c} ; 2 \mathrm{lb}$. cans, $60 \mathrm{c}$.

CALIS SPRAY No, 1. Nicotine and sulphur mixed. Fine for dusting vegetable plants for the elimination of aphis and the prevention of mildew and fungus on beans, melon vines, etc. Can, $45 \mathrm{c}$.

CALIS SPRAY No. 81. A mixture of nicotine and lead arsenate. Destroys snails, wood lice, beetles, squash bugs. Price, per can, $50 \mathrm{c}$.

EL ROY GOPHER POISON. A mixture of grains and fruits thoroughly poisoned. Has proven very satisfactory. Small cans, $35 \mathrm{c}$ large cans (Farmer's size), $\$ 1.00$.

\section{TOOLS AND SUNDRIES FOR THE GARDENER}

SPRAY PUMPS AND DUSTERS

HUDSON TANK SPRAYER. One of the most useful of sprayers for the farm, gar-
den, orchard or poultry ranch. We have the Hudson SENIOR and the JUNIOR, both made out of heavy galvanized iron or brass, seams pressed under hydraulic pressure and riveted.

Pumps made of heavy brass tubing. The nozzle, automatic, can be adjusted to heavy or light spray. Three foot extensions can be furnished at $50 \mathrm{c}$ each.

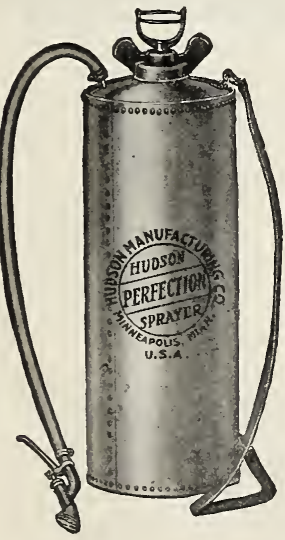

HUDSON, SENIOR. Capacity, 5 gallons. Galvanized, $\$ 8.00$; brass, $\$ 10.00$.

HUDSON, JUNIOR. Suitable for home gardens, greenhouse work and other places where a smaller pump is required. The nozzle and the hose are exactly the same as in the Senior; pump of standard size. All the difference is that the tank is smaller and is of three gallon capacity Galvanized iron, $\$ 5.00$; brass, $\$ 7.50$.
STANDARD SPRAY PUMP. The best and most powerful piece of low priced spraying apparatus on the market today. Can be used with bucket knapsa tank or barrel for spraying orchards, gardens, vineyards, white-washing, disinfecting chicken houses and killing vermin on stock. Made entirely of brass with two solid brass ball valves. No leather suckers or washers. No castmotion and absolutely nothing to get out motion and absolutely nothing to get out the purchaser for five years. You can spray the purchaser for five years. You can spray the work easy, as it throws more spray with less labor than any pump made. The Standard Spray Pump is not a com. pressed air spray pump. It is a very simple and powerful direct acting force

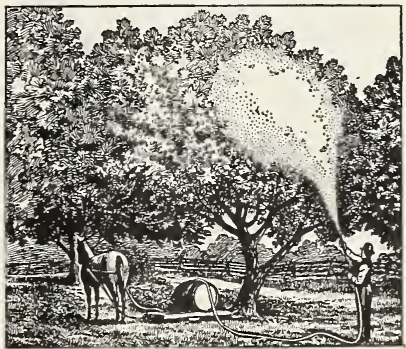

Standard Spray Pump

pump, so carefully designed and accurately pump, so cariction is reduced to the minifractically every ounce of force the user exerts on the plunger is available in
useful work. It is not possible, of course, useful work. It is not possible, of course, to stand on the ground and throw a mist 35 feet in the air. So, with ordinary pumps you need ladders, platforms or extension rods. With the Standard Pump, however, the process is diferent. Standard are made to produce the mist-like spray in the tree at heights varying from 2 to 3 feet to 35 feet. For spraying tall tion in particles of sufficient size to carry well to the topinost branches. These small drops strike with great force against branch, twig and leaf, where they break into the finest kind of a mist, which completely covers all the surrounding parts. The force of these larger particles also resists the wind and penetrates the thickest foliage. Price, $\$ 6.50$.

AUTO SPRAY PUMP. This little pump is built on the same lines as the Standard Spray Pump. It is a truly continuou sprayer. Of very simple design and giving good satisfaction. We have sold a great many during the past season to farmers. nurserymen and home gardeners and all of these purchasers have expressed great satisfaction with this little pump. This pump is made entirely out of brass with reciprocating brass valves and is very seldom out of order. Price, $\$ 6.50$.

GLASS JAR SPRAYER. This is a most ex cellent little sprayer where poultry and gar den are kept on a small scale. This spraye is suitable for disinfecting both. The tank consists of a Mason Fruit Jar, which is very easily unscrewed from the pump, and when not in use this jar can be set away. Different sprays are used for the poultry and garden, and each different spray can be kept in a separate fruit jar, properly labeled, and screwed onto the pump as they are needed. This saves the expense of keeping several pumps on a small place. This pump has a double nozzle and its easy operation as well as its durability makes it highly recommendable. Price, $\$ 1.00$.

CONTINUOUS SPRAYER. This sprayer is what the name implies. By means of a small air chamber attached there is sufficient pressure to keep the spray continuous while the operator is making the back stroke of the arm, during which time most atomizers are at rest. These little pumps come in tin at the price of $\$ 1.00$, and with brass tanks which sell at $\$ 1.50$ each.

HUDSON MAGIC BUCKET PUMP. A pump that will spray whitewash or any other mixture. Made of solid brass, no leather valves to wear out or be eaten up by the whitewash. Throws a continuous stream and is so simple that a child can take it apart. The Pump shown on this page is almost entirely of the best grade of brass, hence it cannot be affected by the action of the whitewash or of any ordinary spraying solution. It is fitted with a Bordeaux nozzle. Altogether it is the most deaux nozzle. Altogether it is the most Price, $\$ 6.00$ each. 
HUDSON MIDGET SYRAYER. A small edition of the above. Price, 35c.

HUDSON MISTY SPRAYER. The accompanying cut shows our Single Tube Tin panying cut shows our Single Tube Tin
Sprayer. The reservoir holds about one Sprayer. The reservoir holds about one
quart, the single tube extending into the reservoir and therefore throws the spray straight ahead, although it will spray in any direction desired. Price, $75 \mathrm{c}$.

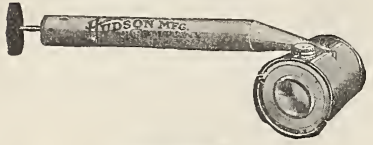

Misty Sprayer

CALIS SPRAY DUST GUN. Made entirely out of metal. Answering a long felt want for a reasonable priced practical duster. Price, $\$ 1.00$ each.

LITTLE BEAUTY DUST PUMP. This pump is made partly out of metal and has a leather blower. Will send dust further than any small duster on the market. Price, $\$ 2.50$.

DEFENDER DUST GUN. Small duster for garden or home use. Price, $15 \mathrm{c}$ each.

GEM DUSTER. White metal box with leather blower. Price, 35c.

\section{Standard Wheel Hoes and Seeders}

Special Catalog Furnished on Request

HALL CULTIVATOR. This is the most practical and low priced thoroughly reliable cultivator on the market. Made entirely out of steel with hardwood handle, and besides the plow it has a furrow, a wheat cutter, and last but not least, a changeable furrower. This last attachment is most unique and the only one of its kind fitted on a hand cultivator. Invaluable for home gardens and nurserymen. We are buying these tools in large quantities direct from the factory and are able to offer them at the low price of $\$ 6.50$ each.

NORCROSS CULTIVATORS. One of the best garden cultivators in existence. The large size have five prongs and handle like a heavy hoe. Walk backwards in using this cultivator, leaving the soil in a perfect pulverized condition. Large size, 5 prongs, $\$ 1.35$ each. Small size, 3 prongs, short handle, $75 \mathrm{c}$ each; 3 prongs, long handle, handle, 75 each.

PLANET JR. No. 4. Combined seed drill, single wheel hoe, cultivator and plow. Complete, $\$ 20.50$. As a seeder only, $\$ 26.00$.

PLANET JR. No. 12. Double wheel hoe, cultivator and plow. Price, $\$ 17.75$.

PLANET.JR. No. 17. Single wheel hoe, cultivator and plow, $\$ 10.50$.

PLANET JR. No. 25. Combined hill and drill seeder and double wheel hoe, cultivator and plow. Price, complete, $\$ 26.00$.

FIRE FLY GARDEN PLOW. Price, $\$ 5.00$. NO. 28 SEEDER. Price, \$26.75.

FORKS. Spading. Short D handle. Each, extra heavy, strapped and ferrulled, $\$ 1.50$ each.

FORKS. Digging; long handle. 4 pronged, strapped and furrelled. Each, extra heavy. 5 prongcd, $\$ 1.75$ each.

FORKS. Hand Weeding. Each, $15 \mathrm{c}$.

FORKS. Strawoerry. Made out of tempered steel, 50c each.

HOES, Planter's hoe. Each, \$1.50.

HOES. Socket shank; all steel, one piece. Each, $\$ 1.35$.

HOES. Warren's. Each, $\$ 1.50$.

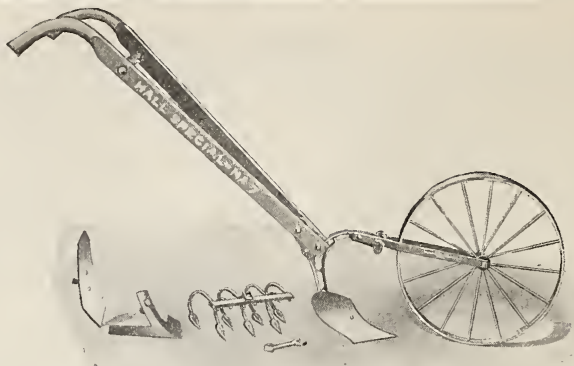

Hall Cultivator

HOES. Push hoes, or scuffle. Each, $\$ 1.00$ to $\$ 1.50$.

HOES. Hoe and rake combined. Each, 85c. MATTOCKS. Garden. With handles, each, $\$ 2.50$.

MATTOCKS. Garden. This is a light tool, with narrow blades made out of the bes tempered steel; 5 ft. handle. Price, $\$ 1.50$ each.

RAKES. All steel; 14 teeth. Each, $\$ 1.25$.

RAKES, 16 teeth. Each, \$1.35.

RAKES. Galvanized iron for lawns. Large size, $\$ 1.50$ each.

SHOVELS. Long handle; round or square. Each, \$1.75.

SHOVELS. D handle. Each, \$1.75.

SPADES. D handle; best steel. Each, $\$ 1.75$.

SPADES. Long handle; sword steel. Each, $\$ 1.85$.

SPADES. Genuine Maynard, with long or short handle. Each, $\$ 2.50$.

TROWELS. Solid socket; best gardener's trowel in the market. Each, $85 \mathrm{c}$.

TROWELS. Common garden trowels. Each, $15 \mathrm{c}, 25 \mathrm{c}$ and $40 \mathrm{c}$.

TURF EDGER. Made of the best cutlery steel; blades half moon shape. Price, $\$ 1.00$ each.

\section{Tools}

SIMPLICITY HEDGE TRIMMER. For fresh new growth only. This trimmer was designed and built to meet and satisfy the demand of thousands who have hedges of demand of thousands who have
some sort around their homes.

The Simplicity is the only trimmer successfully demonstrated and proved to be a wonderful advancement over the old style hedge shear.

No experience necessary to cut a first class job. Think of it. With each complete movement of your hands you actually save seventeen blistering, tiresome "snips" or "whacks" the old hedge shear way.

The trimmer is to be used only for cutting the new growth. Do not use it for cutting second year growths or pruning.

With its perfect balance it really seems to work almost automatically for, besides Simplicity's two pound weight and 12 inch width, it has 19 big, safe, keen teeth cutting cleanly both when opening and closinc. Simplicity's are made of the finest high grade carbon steel and will give you long service and satisfaction. Price, $\$ 5.00$.

SIMPLICITY HEDGE PRUNER AND TRIMMER. For pruning back old growth and trimming new. This implement is the acne of perfection, and far in advance of the present day pruner or lopping shears. To anyone who has ever pruned or lopped hedge or shrubbery with the old-fashioned pruner or lopping shears, there is no need to point out the revolution that came with this great invention. The Simplicity Pruner or Lopping Trimmer.

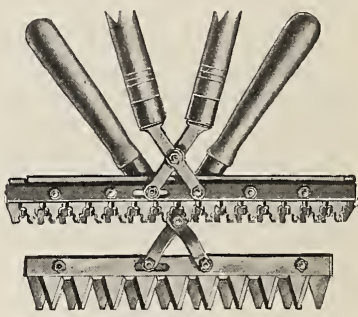

Simplicity Hedge Trimmer

With the Simplicity you can actually do as much work in one hour as you formerly did in four hours with the old style prune or lopping shears. Simplicity cuts both opening and closing. Think of it. What a time and energy saver this is, with each complete movement of your hands you save complete movernent of your hands you save 29 jolting, blistering and tiresome whacks the old pruner or lopping shears way. It seems to work almost automatically and it works.

With its perfect balance and only threepound weight, besides Simplicity's 16-inch width, it has 31 big safe, keen fluted teeth cutting cleanly both when opening and closing.

The Simplicity Pruner Trimmer can also be used for trimming with excellent results. Many home users have chosen it to do all their trimming. Price, $\$ 7.50$.

GALVANIZED TROWEL. No. 85. Made of a single piece of heavy galvanized steel. Handle and blade all in one piece. No wood handles to break or come off. An excellent tool at a low price. Length of blade, 6 inches. Price, $10 \mathrm{c}$ each.

MOE'S GARDEN TROWELS. No. 80. One piece pressed steel. Handsomely finished in black enamel. Length of blade, 6 inches. Ground and polished points. Each, $25 \mathrm{c}$.

MOE'S TRANSPLANTING TROWELS. No. 81. Transplanting trowel. One piece
pressed steel. Handsomely finished in black pressed steel. Handsomely finished in black
and baked enamel. Length of blade, 6 and baked enamel. Length of blade, 6 polished points. Each, $25 \mathrm{c}$. 


\section{DOG AND POULTRY FOODS AND REMEDIES}

MOE'S DROP BOTTOM WALL FOUNTAINS. No. 40 . A practical, durable fountain. Easy to fill and easy to clean. Made of best quality galvanized iron. May be of best quality galvanized iron. May dirt. Suitable for chicks, fouls or pigeons. dirt. Suitable for chicks, fowls or pigeons. Fitted with wire handles, so that two or
more fountains, back to back, can be carried in one hand. Price, 2 qts., $\$ 1.00$ each; 1 gal., $\$ 1.30$ each; 2 gals., $\$ 1.65$ each.

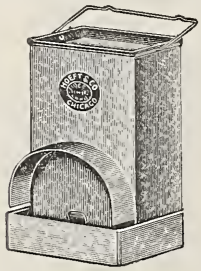

MOE'S IMPROVED WALL FOUNTAINS. Made of heavy galvanized iron, in three sizes. The covered outlet keeps out dust and dirt, and the outlet is further protected by a removable plate which prevents any floating rubbish from being drawn into the reservoir. Price, 2 qts., $\$ 1.00$ each; 1 gal., $\$ 1.25$ each; 2 gals., $\$ 1.50$ each.

MOE'S WALL FOUNTAINS. Removable bottom; easily cleaned. A practical and convenient style of fountain, made of heavy galvanized iron. Can be hung on the wall, up out of the litter. A very popular style with many breeders. Made with a removable bottom, so that all parts may be easily cleaned and kept in a sanitary condition. Capacity about one gallon. Price, $80 \mathrm{c}$ each. MOE'S BOTTOM FILL FOUNTAINS. This fountain fills the breeder's requirements for a good inexpensive article. Made in two pieces accurately stamped and Easily filled and cleaned. The round taper shape prevents bursting from freezing. Made of best quality galvanized iron in three popular sizes. Price, 1 qt.,
$40 \mathrm{c}$ each; 2 qts., $50 \mathrm{c}$ each; 1 gal., $65 \mathrm{c}$ each.

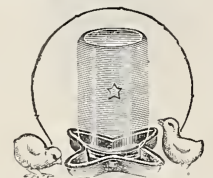

THE FAMOUS STAR FOUNTAIN, OUI Star is the most popular "best seller" that a dealer can handle. Convenient, practical, low in price, and durable. Made of a single piece of heavy non-rusting metal. No seams, no solder, no loose parts. Can not seams, no solder, no loose parts. Can not leak. Provides a greater drinking surface than the round fountain. Can be used for
feed as well as water. Little chicks will not drown. Made in one size only, which will fit any Mason jar, in sizes 1 pint, 1 quart and 2 quart. (We do not furnish the glass jars.) Price, $10 \mathrm{c}$ each.

MOE'S ROUND BABY CHICK FEEDERS. The most popular baby chick feeders on the market. Made of best quality galvanized iron, accurately stamped with dies, and well made in every detail. The top fits snugly, yet can be easily taken apart for cleaning and filling. A great feed saver, as the chicks can not get into it and contaminate the feed. Can also be used for water or milk. Chickens can not upset it. Made in two popular sizes.

No. 12. Diameter $81 / 4$ inches with 12 holes. Price, $25 \mathrm{c}$ each.

No: 11. Diameter 6 inches with 8 holes. Price, $15 \mathrm{c}$ each.

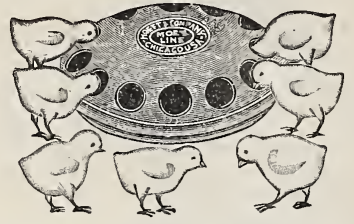

MOE'S POULTRY VEGETABLE RACK. Made of best quality galvanized iron, with galvanized wire rack. A practical device for holding roots, beets, cabbages, sprouted or holtering oats, clover, etc., and prevents scattering trough catches the small tender leaves, and is easily cleaned. The feed saved soon pays for the racks. Height 13 inches. Price, 90c each.

STANDS FOR ROUND FEEDERS. When used with our No. 11 and 12 round feeders makes them suitable for growing chicks. Holds the feeders at the proper height up out of the litter. Made of galvanized iron. Height $13 / 4$ inches. Price, $5 \mathrm{c}$ each.

MOE'S SANITARY FEEDING TROUGHS For grown fowls. Suitable for dry feed,
wet mash or water. The tops slide off, so wet mash or water. The tops slide off, so
the pan can be easily cleaned and filled. the pan can be easily cleaned and filled.
Made of the best quality galvanized iron, accurately stamped with dies. The edges of the slotted openings are all turned over and smoothly finished. No sharp or rough edges to injure the chicks.

Price, 12-inch length, 5-inch width, 45c each.

18-inch length, $5 \mathrm{I} / 2$-inch width, $65 \mathrm{c}$ each.

24-inch length, 6-inch width, $85 \mathrm{c}$ each.

MOE'S DOUBLE FEEDING TROUGHS. For chicks and growing stock. Made of For chicks and growing stock. Made of stamped with dies. No sharp or rough edges stamped with dies. No sharp or rough edges
to injure the clicks. Sliding top. Easy to fill and clean. Made in three sizes.

12 -inch length, 18 holes, $45 \mathrm{c}$ each.

18-inch length, 26 holes, $60 \mathrm{c}$ each.

24 -inch length, 36 holes, $70 \mathrm{c}$ each.

MOE'S MAGAZINE CHICK FEEDER AND WATERER. A new round chick feeder with a magazine container to hold a good quantity of feed. The upper magazine is fitted to the feeder top with a spiral thread so it can be adjusted up or down to fced the various kinds of grain. It can also be used as a drinking fountain, as the magazine is water and air tight. Diameter of feeder $8 \mathrm{~T} / 4$ inches, height $8 \mathrm{I} / 2$ inches, capacity 2 quarts. Number of feeder holes, 12 Price, $70 \mathrm{c}$ each.

MOE'S GRIT AND SHELL BOXES. The feeding of grit, ground shells, and charcoal is now recognized as an essential part of the diet, to keep fowls in healthy prime condi tion. There is no more economical method of supplying grit, etc., than with these practical, inexpensive compartment boxes. No solder used in their construction. Can also be used as feed hoppers for little chicks. Made of heavy galvanized iron in three Made of heavy galvanized iron in three sizes. The No. 45 for baby chicks has a
square bottom, the other sizes have round square bott
bottoms.

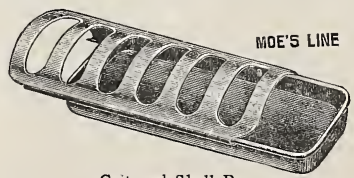

Grit and Shell Box

No. 45. Grit boxes for baby chicks. Has two compartments. Height 8 inches. Width 5 inches, Price, $45 \mathrm{c}$ each.

No. 9. Grit box. Has three compartments. Height 13 inches; width $81 / 2$ inches. Each, $\$ 1.00$.

No, 90 . Grit box. Has four compartments. Height 13 inches, width 11 inches. Price, \$1.35 each.

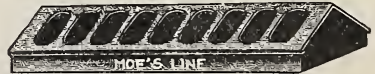

Dry Mash Hopper

MOE'S DRY MASH HOPPERS. A dry mash hopper of great merit, made of heavy galvanized iron. All parts accurately stamped with dies. The curved bottom keeps the feed within easy reach of the birds, and the taper shape of the hopper, larger at the bottom, prevents the feed from cloge wire grid and the wires running from the flange through the wire grid prevent the fowls from throwing out or wasting the feed. The sloping top prevents them from rooting on the hopper. When weather proof. Made in four sizes.

Height

19 inches

Capacity

Price

19 inches $\quad 12$ inches 14 qts. $\quad 2.20$

10 qts.

$\$ 1.65$

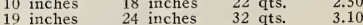

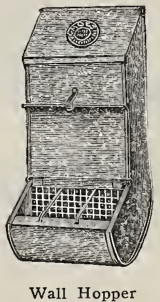

MOE'S EGG TESTER. To test the fertility of eggs during the period of incubation. Used with an ordinary lamp (No. 2 burner) in a dark room. It will illuminate the interior of the egg and show if the chick is alive, and also shows the size of the air cell in the egg. Made in one size only. Price, $45 \mathrm{c}$ each.

\section{DOG REMEDIES}

CLAYTON'S DOG REMEDIES. The best known and most widely used of all dog remedies. The following are $50 \mathrm{c}$ each : Mange Remedy, Skin Lotion, Hair Tonic, Distemperine Liquid (Tablets), Condition Pills with Pepsin, Blood Purifying and Cooling Pills, Digestive Tablets, Laxative Pills, Worm Pills, Tape Worm Expeller, Pills, Worm Pils, (Soft Capsules), Canker Vermifuge (Liquid) (Soft Capsules), Canker Lotion Liquid (Tablets), Eye Lotion Liquid (Tablets), Fit Remedy Liquid (Tab-
lets), Cough Remedy, Sulphur Tablets, lets), Cough Remedy, Sulphur Tablets, rhoea Remedy Liquid (Tablets), Chorea Tablets. Goitre Remedy, $\$ 1.00$; Ceoline Dog Wash and Disinfection, $35 \mathrm{c}$; Shampoo, 25; Kilflea Soap, 25c; Cream Dog Soap, 25; Ceoline Dog Soap, 25c; Kilflea Powder, $35 \mathrm{c}$.

WALKER'S DOG AN PUPPY BISCUITS. Made out of good flour, fresh meat and veretables. Made for us in one of the oldvegetables. Made for us in one of the same good flour is used in making these biscuits good flour is used in making these biscuits as for the best pies, breads and cookies.
Price, $35 \mathrm{c}$ per package. $50 \mathrm{lb}$. sacks, $\$ 5.50$. both covers are closed it is rate, mouse and 


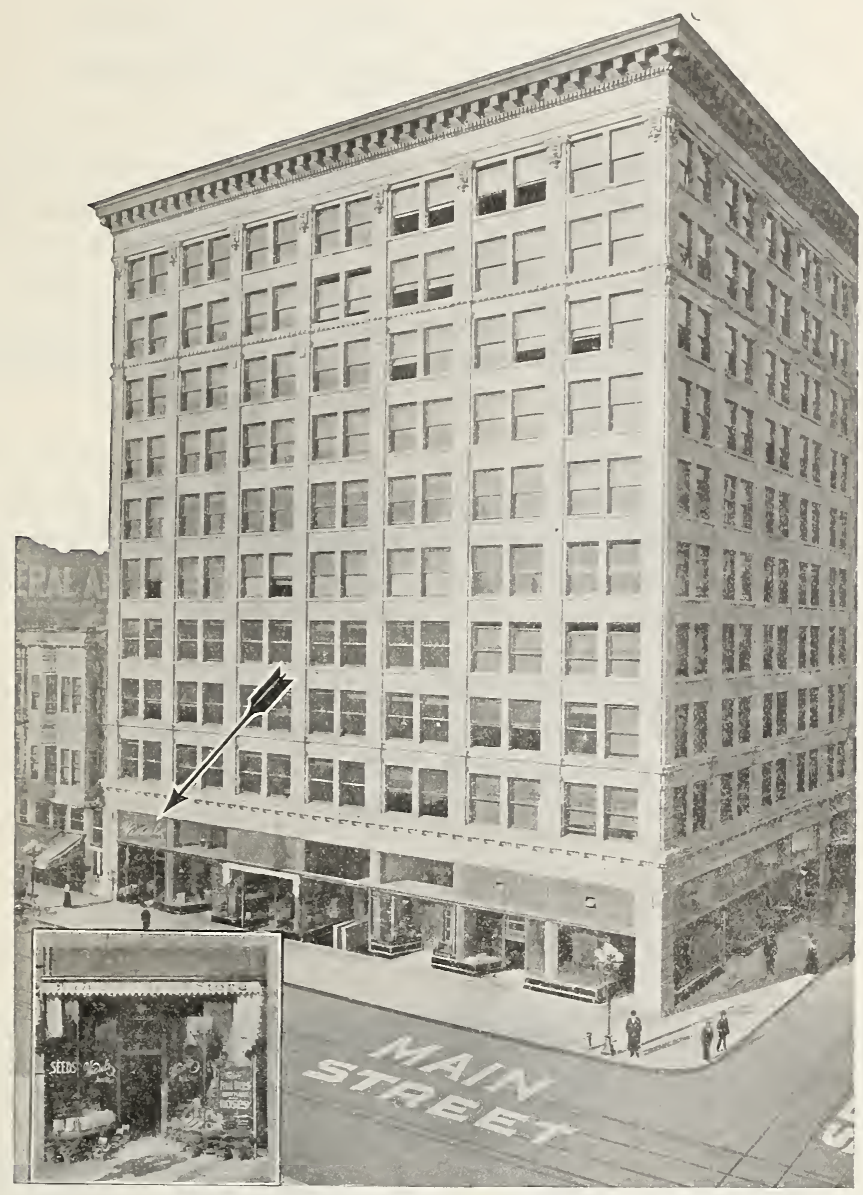

\section{OUR STORE: CONVENIENT TO MOTORISTS}

W

INSEL-GIBBS SEED STORE is located on the fringe of the congested district, making it very convenient for the shopping motorist. The intersection at Second and Main Streets is one of the safest in the city on account of traffic having an outlet in all directions. Coming in from the San Fernando Valley points or Hollywood drive in via Sunset Boulevard to Main Street and south to Second; from Santa Ana and adjoining towns drive in Whittier Boulevard to Euclid Avenue, north to Fourth Street and west to Main; from San Pedro, Long Beach, Compton and adjoining towns drive in either Long Beach or Harbor Boulevards to Main Street, north to Second; from Huntington Park follow Santa Fe Avenue to Fourth Street and west to Main Street. The Third Street Tunnel is a very convenient outlet from and to the west side of the city, and with the completion of the Second Street tunnel access to this store will be simplicity itself. 


\section{AN INVITATION AND A PROMISE}

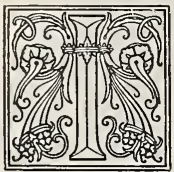

NTENDING PLANTERS are cordially invited to visit and inspect our nurseries and growing grounds at Forty-ninth and Main Streets, where a complete and varied assortment of economic and ornamental trees and shrubs, vines, palms, roses, flowering and vegetable plants are on display, in all stages of growth.

Persons not familiar with the growth and habits of the many different varieties of ornamental trees and shrubs will find it a pleasure and an education to spend a few hours in our nursery and greenhouses. Competent and courteous attendants will meet your pleasure.

Out-of-town customers will find the order sheet on the opposite page a convenience in placing their order; it will receive careful, prompt attention and will be forwarded to you ready for planting.

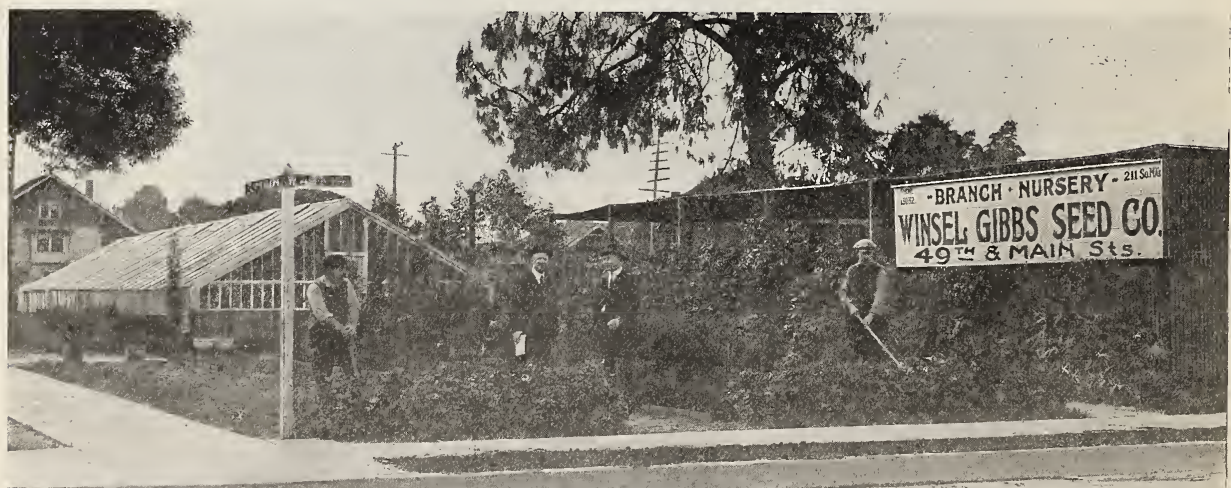


O PLEASE USE THIS ORDER SHEET

\section{WINSEL-GIBBS SEED COMPANY \\ 211 SOUTH MAIN STREET \\ LOS ANGELES, CALIFORNIA}

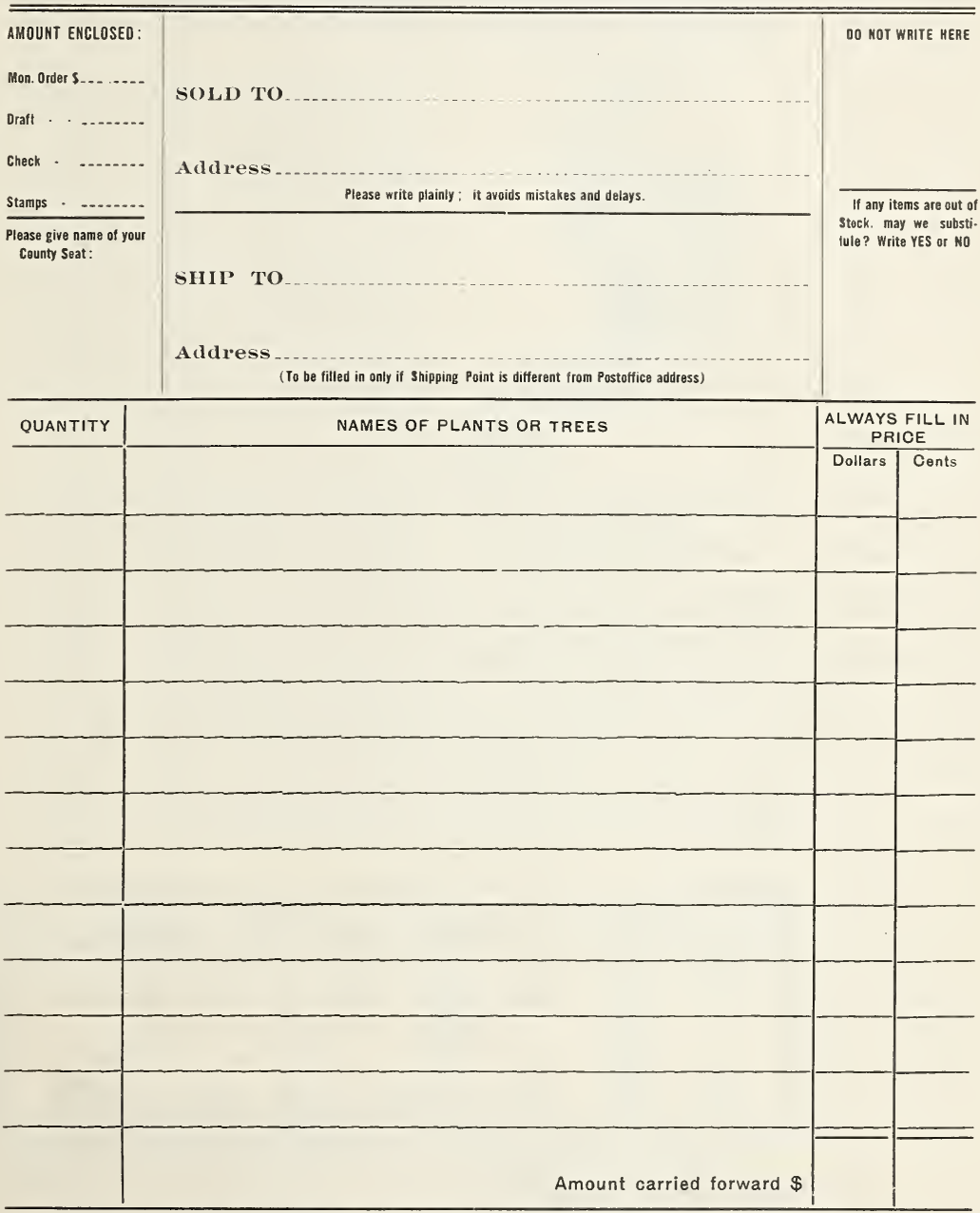

We do not warrant in any way, expressed or implied, the contents or description, quality or productiveness, or any other matter of any seeds, bulbs, plants or trees, sold by us, and we will not be in any way responsible for the crop. If the purchaser does not accept these goods on above terms no sale is made thereof, and he must return them at once, and money will be refunded. Subject to above conditions we make sale. 
O-MAKE ALL MONEY AND EXPRESS ORDERS PAYABLE AT LOS ANGELES, CAL.

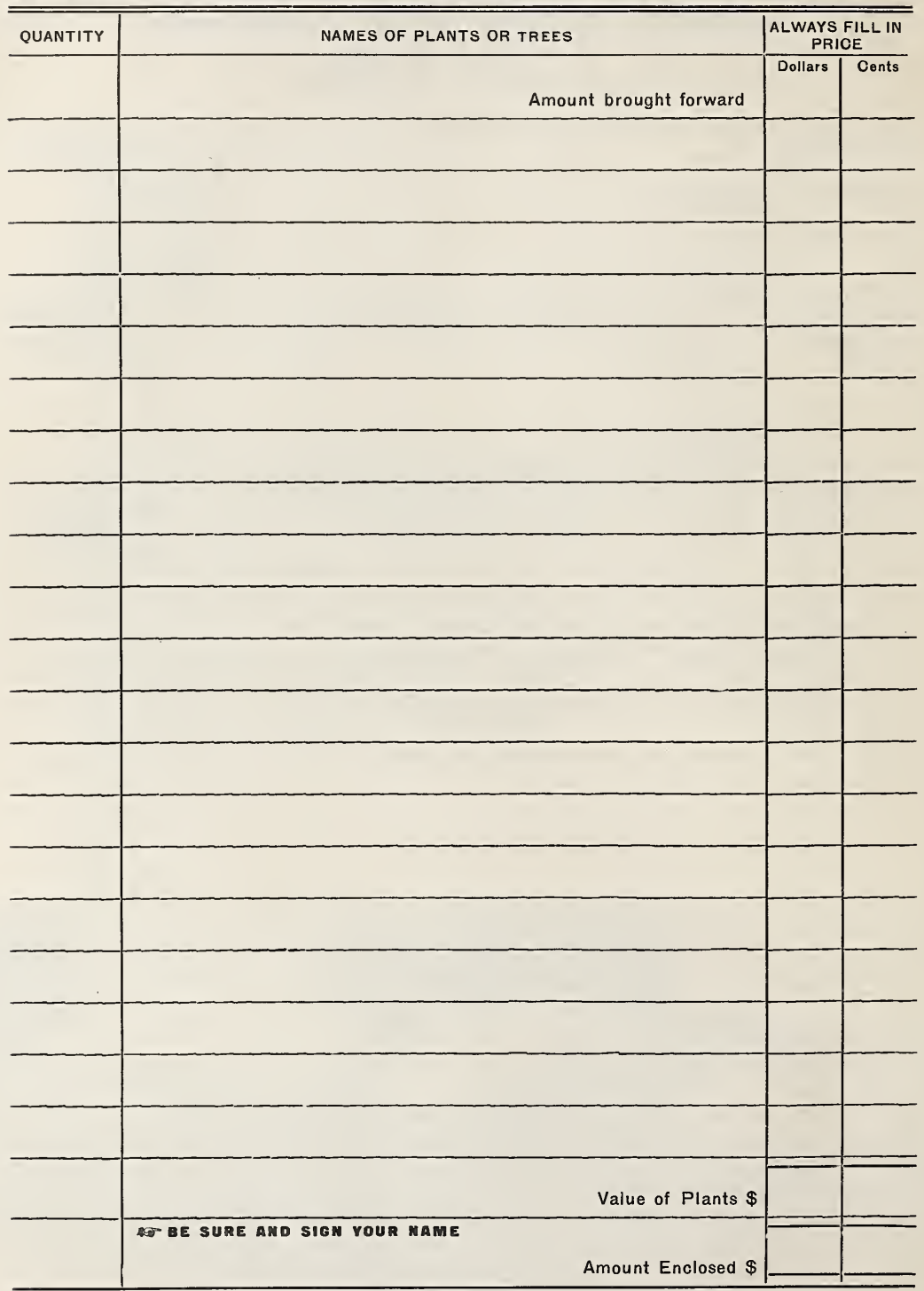




\section{FREE \\ Dr. LeGear's Poultry School Course}

Here is your chance to get FREE, the poultry knowledge and experience of Dr. L. D. LeGear,V.S. nationally known poultry expert.

Few poultry authorities today understand the theory, science and actual practice of poultry raising as does Dr. LeGear. His knowledge is not simply theory, but the practical and certain knowledge that comes from years of personal poultry raising experience.

Dr. LeGear took up scientific and practical poultry raising on a commercial basis thirty years ago, and, except for the necessary aid of helpers, took actual charge of his flocks himself.

In the course of his many years of personally handling his own flocks, and the flocks of others, he has conducted hundreds of experiments to develop the best methods of breeding, mating, hatching, brooding, housing, feeding for eggs, feeding for fattening, culling and conditioning, and has prepared reliable prescriptions for the prevention and treatment of poultry diseases.

During the past twenty years, Dr. LeGear's poultry have invariably been the big prize winners at every national poultry show at which they were exhibited, including the International Poultry Exhibition at the San Francisco World's Fair.

Never before have you had such a remark-

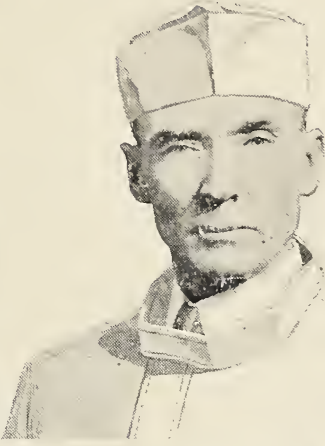

Dr. L. D. LeGear, V. S.

In Surgeon's Robe

Trade Mark Reg. U. S. Pat. Office able offer as this. Think of it! 33 complete lessons, illustrated with scores of pictures and charts, personally written by this famous poultry expert.

In this course of instruction, Dr. LeGear outlines the unfailing methods used by him in his thirty years as poultryman. He tells you how to get eggs regardless of weather conditions. How to build your houses. How to feed chicks from start to finish. How to mate for fertility. How to get big hatches. How to pick out the drones. In fact, in this course Dr. LeGear tells you everything about poultry.

If this course were offered for general sale, it would cost you upwards of $\$ 70.00$, but it is absolutlely free to users of Dr. LeGear's remedies, under the doctor's offer.

Below are illustrated a few of the 33 lessons of the complete Dr. LeGear's Poultry School Course.

This is the kind of poultry instruction you want. These 33 lessons take you every step of the way to poultry raising success. See us at once with reference to them. Let us show you the lessons and give you full information on this most remarkable offer ever made to poultry raisers.

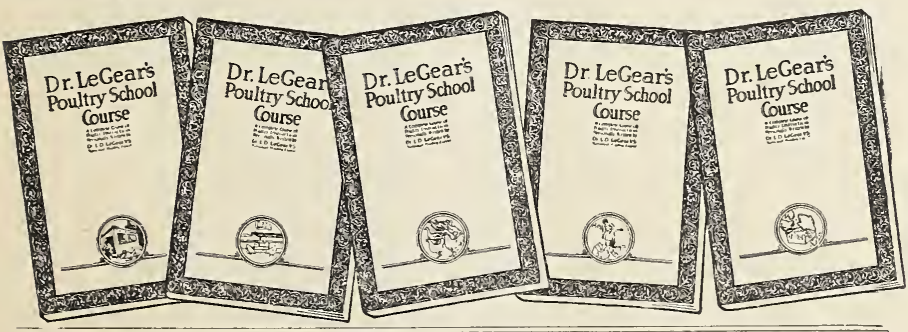

Dr. LeGear's Remedies:

One for every curable ailment of stock or poultry. 


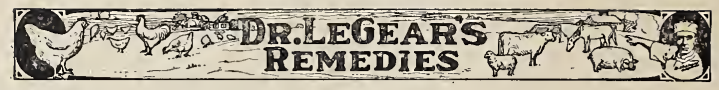

Poultry raising can be made both interesting and profitable. Proper housing, feeding, care and attention are necessary. Unhealthy conditions must be avoided, ailments treated, diseases combated and epidemies and contagion stamped out. It is as wise to have a Poultry Remedy Cabinet, as it it is to have a Family Medicine Cabinet.

Dr. L. D. LeGear, for 30 years America's foremost Expert Poultry Breeder and Graduate Veterinary Surgeon, national poultry exhibitor and holder of the highest award prize ribbons, has compounded a reliable and guaranteed remedy for every curable poultry ailment. They are his personal formulae, used in his own breeding pens of prize winners, made from the purest ingredients, of uniform quality and strenght, carefully prepared, thoroughly tested and put up in sealed containers, with full directions for use.

Dr. LeGear's Remedies are used with perfect satisfaction by thousands of poultry and stock raisers. We unhesitatingly recommend them, because we know their merit and know that they will do what is claimed for them. See us for prices on them.

\section{Dr. LeGear's Poultry Prescription}

\section{MORE EGGS}

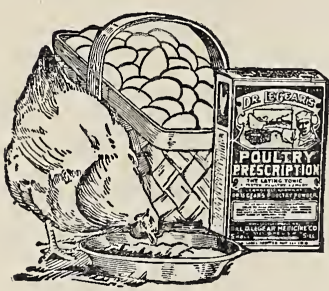

\section{PRODUCES}

\section{FASTER GROWTH}

Profit in Poultry is largely a matter of healthy chickens with good digestion and assimila tion. The healthiest poultry, like the healthiest people, need help at times.

If you raise poultry for the the market, you want heavy fleshy birds, Dr. LeGear's Poultry Prescription produces fine, fat poultry .

If you keep poultry to get eggs. get a maximum yield.

In cold, damp weather, a hen consumes most of the energy created by her food to keep hcrself alive. To stimulate her eggproducing organs, and keep her laying, she dosen't need more bulk in food, but elements that furnish her with excess energy.

Winter is the hen's slacker season, but it is the very time when egg prices are high. Offset winter conditions. Supply the elements that insure egg making.

The moult is a severe test on a hen's strenght. It calls on her to use all her surplus energy and flesh to make feathers. A hen can't make feathers and lay eggs at the same time. She must have a tonic during this period to supply her with more energy and help her digest and use every ounce of her food to recover quickly from this strain so that she will be in shape for early and heavy winter laying.

Give your poultry Dr. LeGear's Poultry Prescription every day. It is a tonic and regulator, and an excellent means of toning up the system; promoting digestion, health and vitality; of producing flesh; shortening the moult; offsetting winter conditions; stimulating the egg-producing organs WITHOUT INJURY. and keeping them in laying condition.

It is the best kind of tonic to insure health and vitality of fowl of every description.

\section{POULTRY PROFITS DEPEND ON HEALTHY CHICKS}

CHICK LOSS is not only chicks that die, but chicks that live as weaklings, requiring more feed and care.

Every chick saved means more eggs for you. Make sure of sturdy quick-growing chicks by feeding them not only wards off disease, prevents bo

Give it daily to your breeders now. It will build up their vitality to resist the many ailments common to chicks and help fertility and make egg producers of all your pullets.

\section{Get a Package or Pail TODAY}

Small Package, 11/2 lbs.

Medium Package, $3^{3}{ }_{4}$ lbs

Large Package, 9 lbs.

25-lb. Pail

$100 \mathrm{lb}$. Keg 


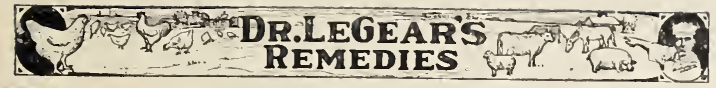

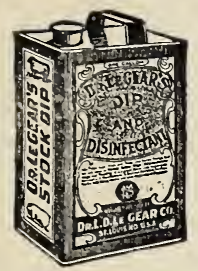

\section{Dr. LeGear's Dip and Disinfectant.}

No poultry yard should be without it. There are a hundred uses for it about the home and yards. . Dr. LeGear's Dip and Disinfectant rids your poultry houses, brooders. incubators and premises of many disease germs, lice and vermin, and keeps them clean and healthful. It is an invaluable antiseptic, disinfectant, germicide, insecticide and deodorant.

For certain conditions, fowls may be dipped into a solution of it, as directed.

It is also good for itch, mange, lice and ticks on live stock. It also keeps the hair and skin in healthy condition.

8 ounce bottles; quart, half gallon, one gallon, five gallon,
and 10 gallon cans; and 50 gallon drums.

See us for prices. Also ask for price on Dr. LeGear's Sprayers

\section{Dr. LeGear's Lice Killer Powder.}

Lice are enemies you must not tolerate in your poultry yard. If lice don't go, your poultry will. Lousy poultry can not be profitable. Lice sap the blood and energy that otherwise would go into flesh and eggs. Lousy hens lay fewer eggs, are unhealthy and cause the death of thousands of baby chicks.

Dust poultry with Dr. Le'Gear's Lice Killer Powder, and place it in the dust bath, and watch lice go.

1 lb. sifter top can

\section{Dr. LeGear's E88} Laying Tablets.

Help to make hens lay and to keep poultry healthy. Scientifically prepared from concentrated drugs. Dissolve tablets in water, then either mix solution with dry mash or use as regular drinking water.

Dr. LeGear's Egg Lay. ing Tablets increase the egg yield and at the same time tone up the system, aid digestion, sharpen the appe

tite and help to keep hens vigorous and healthy.

Medium and large packages.

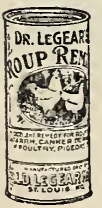

\section{Dr. LeGear's Roup Remedy}

For roup, colds and other catarrhal affections. Roup is very fatal and contagious, of ten wiping out practically the whole flock especially young birds.

At the first birds. separate the affected birds from the rest, and stamp out this disease with Dr. LeGear's Roup Remedy.

It will pay you to keep a can on hand at all times.

$$
2 \text { oz. can }
$$

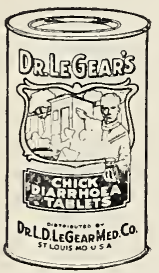

\section{Dr. LeGear's}

\section{Chick Diarrhuea Tablets}

Chicks are delicate for the first
few weeks and sbould have special
care during that time. These
tablets help you to save them from
diarrhoea and other troubles, be-
cause they put chicks in good,
healthy condition, and regulate the
system and bowels, which helps
them to ward off disease and grow
strong and vigorous.

Can of 30 tablets

\section{Dr. LeGear's Poultry Bowel Regulator}

Diarrhoea and other forms of bowels trouble are very common with poultry.

Dr. LeGear's Poultry Bowel Regulator is an intestinal antiseptic and astringent, which is very beneficial in many cases of loose bowels and diarrhoea.

\section{Box of 30 tablets}

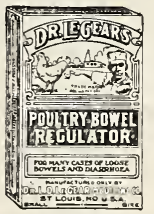

For baby chicks use Dr. LeGear's Chick Diarrhoea Tablets

Dr. LeGear's Cold Tablets. A special remedy for preventing and curing colds, roup and similar In case of colds, put all sick fowls to themselves in a clean, dry, well ventilated house, free from drafts and dissolve two tablets in each quart of drinking water, and allow no other water to drink.

For prevention, give all your fowls one tablet in each quart of drinking water.

$$
\text { Can of } 30 \text { tablets }
$$

Dr. LeGear's Remedies: $\begin{aligned} & \text { One for every curable ailment of stock or } \\ & \text { poultry. }\end{aligned}$ 


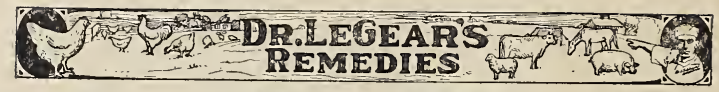

\section{Dr. LeGear's Head} Lice Remedy

A safe eradicator of lice from the heads and from under th wings of chicks. It stops short the greatest enemy of chicks. It gives them a chance at a time when quick growth an vigor mean everything. Don't let lice get a start. Be pre-
pared for the first signs of droopy chicks, by having Dr. LeGear's Head Lice
Remedy on hand.

Put up in 2 oz. friction top tin boxes to keep it airtight and clean.

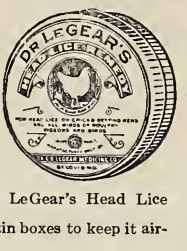

Dr. LeGear's Sore

Head Remedy

For sores, injuries and disease the comb wattles, such as sorehead (chicken pox) frost such as sorehead (chicken pox) frost bite, etc. Good for all kinds of poultry an pigeons. An application each day for a short time, will quickly remedy these ailments. If the sores are at all serious, separate in a clean, dry place, thoroughly disinfecter with Dr. LeGear's Dip and Disinfectant and give Dr. LeGear's Poultry Prescription with their feed twice a day.

2 oz. tin

\section{Dr. LeGear's Stock Remedies and Other Preparations}

In addition to the above indicated poultry remedies, Dr. LeGear has also prepared a full and complete line of stock remedies, and certain other preparations, all of the highest merit and quality.

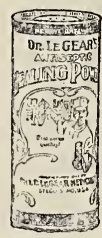

\section{Dr. LeGear's Antiseptic} Healing Powder

A dry, eleansing powder. Heals quickly barbed-wire cuts, collar galls, old sores, rope burns, etc. It forms an antiseptic coating over a sore, which prevents infection and keeps off flies. An exposed sore or cut may cost a valuable animal. Keep Dr. LeGear's Antiseptic Tealing Powder on hand for emergencies.

Small and large sifter top cans

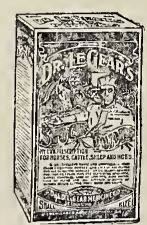

Dr. LeGear's Stock Powders

A tonic, conditioner, appetizer and worm expeller. They help cows to give more and richer milk; hogs, sheep and steers to grow faster; horses and mules to work harder. They tone up the system, purify the blood, ward off disease, and are good for coughs, colds, distemper, kilney troubles, hide-bound, etc.

Small, medium and large packages, $25 \mathrm{lb}$. pails and $100 \mathrm{lb}$. kegs.

\section{Dr. LeGear's}

Fly Chaser

Live stock tormented by flies can not be productive. Flies will cause your cows to fall off in milk production your steers to lose flesh and your horses to las at work. Dr. LeGear's Fly Chaser drives away flies, gnats and mosquitoes. Spray the floors and stalls of your stables with it.

Quart, half gallon, one gallon, 5 gallon and 10 gallon cans, and $\mathbf{5 0}$ gallon drums.

\section{Dr. LeGear's Hog Prescription}

Will help to rid your pigs and hogs of stomach, bowel and kidney worms. Good for man cases of coughs, colds, constipation, piles, paralysis, thumps, scours, diarrhoea and indigestion An excellent blood purifier and general all round hog tonic that every hog raiser should have on hand always. It stimulates th digestive organs, so that the maximum feed is turned into flesh and fat, thus producing healthier and bigger hogs.

$$
3^{3 / 4} \text { lb. pkg. }
$$

25 1b. pail

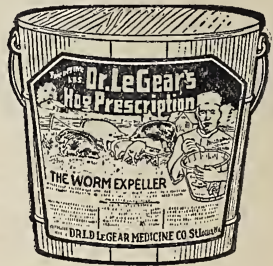

Dr. LeGear's Blister (Spavin Remedy)

Dr. LeGear's Gall Remedy

Dr. LeGear's Heave and Distemper Remedy

Dr. LeGear's Worm Remedy
Dr. LeGear's liniment
Dr. LeGear's Colic Remedy

Dr. LeGear's Eye Water

Dr. LeGear's Antiseptic Healing Oil

Dr. LeGear's Screw Worm Killer

Dr. LeGear's Fly and Insect Powder. Also let us show you Dr. LeGear's special large powder blower.

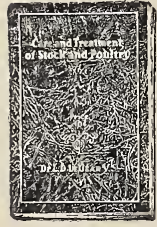

Dr. LeGear's Book, Care and Treatment of Stock and Poultry

You know when your poultry and stock suffer from disease. But, do you know what the disease is. And do you know what remedy to use. Why not consult Dr. LeGear's book,

It is a real first aid to stock and poultry raisers. Just the handiest book on stock and poultry ailments you could want. A regular encyclopedia of the things you want to know. I contains 128 pages, with charts and illustrations, devoted exclusively to this one subject. Used as a text book by Veterinarians and Schools. Written in plain language. Ailments are thoroughly discussed and proper treatment recommended.

We will gladly mail you one, on request.
Dr. LeGear's Remedies: One for every curable ailment of 
P. 0 .

State

WINSEL-GIBBS SEED CO. GROWERS SEEDS DEALERS LOS ANGELES 


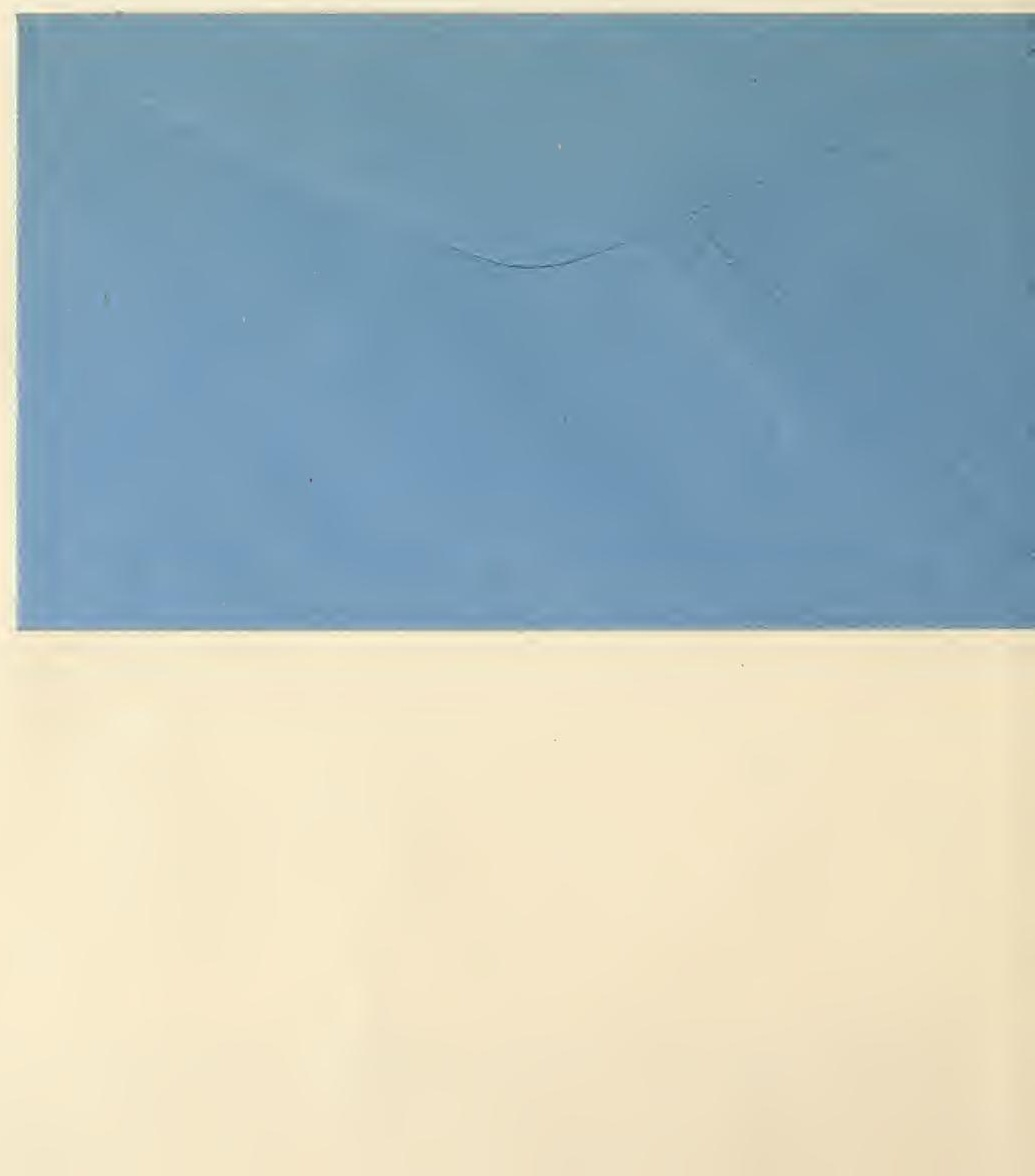




\section{INDEX}

Planting Chart for cach Peppers ........16-17 month of year....................2-4 Pumpkins _... 17

Lawn Making and Care of Rhubarb .............. 17

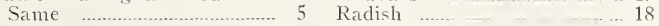

Fcrtilizers 6 Salsify .......................... 18

\section{VEGET ABLE SEED}

Artichoke

Asparagus ................................. 7

Beans, All Varicties...............7-9

Beets-Table, Field, Stock.

Brussels Sprouts

9
9

Cabbage, 111 Varieties $\quad 9-10$

Canteloupcs 13-14

Carrots ................................. 10

Casaba ……................................ 14

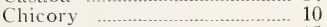

Citron …............................... 15

Collards …........................... 10

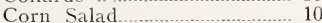

Cauliflower ….......................10-11

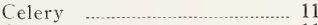

Corn …....................................... 11

Cucumbers ……............................. 12

Dandelion …................................ 12

Egg Plant................................. 12

Endive …............................................... 12

Garlic ...................................... 15

Kale or Borecole..................... 12

Kohl Rabi.............................. 13

Leek ............................................. 13

Lettuce … 13

Mustard 15

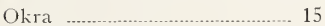

Onion Seed ………….........15-16

Onion Sets................................ 16

Parsley .................................... 16

Parsnips ……........................... 16

Peas 16

Seed Potatoes..... 20

Spinach ................ 18

Squash _......................... 18

Swiss Chard _........... 19

Tomato …................. 19

Tomato Plants.......... 19

Turnips …......................... 20

Water Cress.................. 20

Watermelons ....................14-15

Aromatic-Medicinal Herbs.. 20

Forage and Fodder Plants... 21

Fruit Trees, All Varieties..22-25

Flower Seed, All Varieties 26-39

Bulbs-Domestic and

Imported

$40-41$

Rose Bushes........................42-43

Decorative Plants.................... 44

Perennial Flower Plants...45-46

Annual Flower Plants............ 46

Climbing-Trailing Plants.... 47

Trces and Shrubs, Ornamental ….........................48-54

Landscape Department......... 55

Treatment of Insects and Diseases in the Garden and Orchard ....................... 56

Insecticides and Fungicides.. 57

Tools and Sundries for the

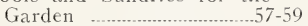

Dog Remedies.......................... 60

Poultry Foods and Remedies 60 
SEEDS that GROW

TREES that BEAR PLANTS that BEAUTIFY WINSEL-GIBBS SEED COMPANY 211 SOUTH MAIN ST LOS ANGELES 


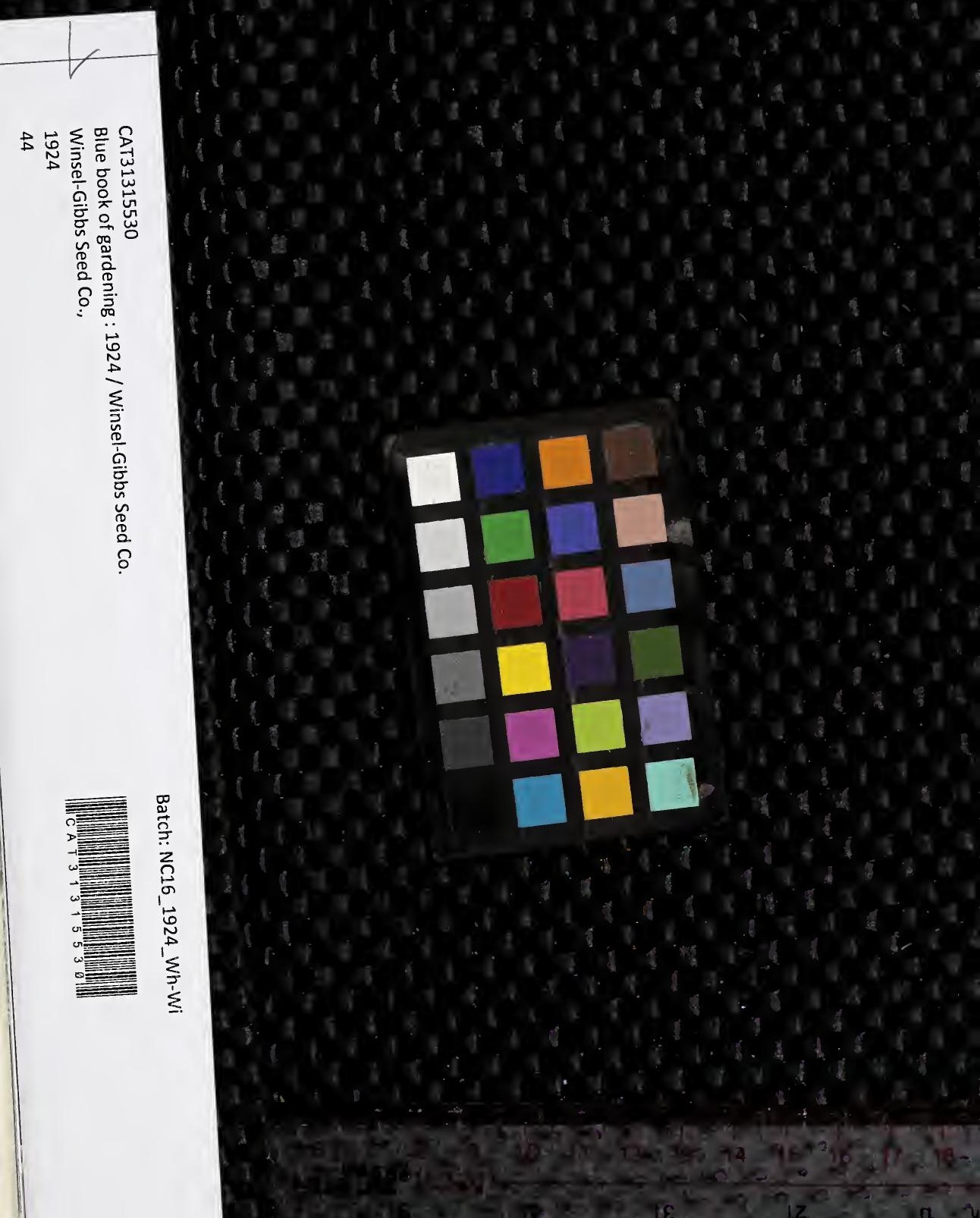

